Editörden

Araştrrma Makaleleri

Güzel Sanatlar Eğitim alanı Olarak Yaratııı Dramanın MEB ve YÖK Programlarındaki Görünümï

Ömer Adıgüzel, Gizem Sivrikaya.

Sumf Ögretmenliği Adaylarının Yaratıc Drama Oturumu Planlama Sürecinde Yaşadıkları Sorunların İncelenmesi

İhsan Metinnam ..

Teaching adolescents Civil Law: Process Drama as a tool for achieving Legal Literacy

Antigoni Laskaridou, Alkistis Kontoyianni, Christina Zoniou, Asterios Tsiaras

Mïzede Sosyal Bilgiler Öğgretiminde Yarațę Draman Bir Yöntem Olarak Kullanımına İliskin Uzman Görüsleri

Merve Ulu, Ferah Burgul Adıgïzel ...... 263

Çocuk ve Drama Dersi Veren Oğretim Elemanlarının Niteliklerine İlişkin Çocuk Gelişimi Programı

Öğrencilerinin Görüşleri

Ömer Nayci. ...... 281

Masal Anlatımımı Illkokul 4. Simıf Öğrencilerini Konuşma Prozodilerine Etkisi

Fatih Çetin Çetinkaya, Muhammet Sönmez...

Editorial

Research Article

How Creative Drama, Which is a Field of Fine Arts Education, is Presented in MoNE and HEC Curriculums Ömer Adıgüzel, Gizem Sivrikaya.. $\ldots . .204$

Investigation of the Problems of Primary School Teacher Candidates in the Planning Process of Creative Drama Session

İhsan Metinnam...... .220

Gençlere Medeni Kanunu Öğretmek: Hukuk Okuryazarlı̆ı Eğitiminde Sürecsel Dramanın Bir Araç Olarak Kullanımı

Antigoni Laskaridou, Alkistis Kontoyiann Christina Zoniou, Asterios Tsiaras..................................... 244

Opinions of the Experts on Employing Creative Drama as a Method in Social Studies Teaching in the Museum Merve Ulu, Ferah Burgul Adigüzel .................................... 264 The Opinions of Child Development Programme Students Related to the Qualifications of Instructors Teaching Child and Drama Lesson

Ömer Nayci...

282

The Effect of Fairy Tales on the Prosody of Primary School 4th Grade Students

Fatih Çetin Çetinkaya, Muhammet Sönmez....................... 297

Eğitimde Drama İle ‘Ötekinin’ Kabulünü Teşvik Etmek Education

Theodora Papaioannou, Alkistis Kondoyianni ................... 309

Görüş Yazısı

Rol İcinde Calısma: Öğretmenler ve Cocuklar

Patrice Baldwin...

Theodora Papaioannou, Alkistis Kondoyianni .................... 309

The Letter of Opinion

Working in Role - teachers and children

Patrice Baldwin...

Yaratııı Drama Dergisine Iilişkin Açıklamalar ve Yazım Kuralları......
Submission Guidelines for Creative Drama Journal...
Creative Drama Journal

Yaratıcı

Drama

Dergisi 
Dış Kapak 


\section{YARATICI DRAMA DERGISI}

\section{Creative Drama Journal}

Cilt 14, Say1 2, Yaz 2019

(Volume 14, Issue 2, Summer 2019)

Çağdaş Drama Derneği Yayınıdır.

Official Publication of the Contemporary Drama Association

Yayın Türü: Yerel Süreli

Type of Publication: Local Periodical

\section{ÇAĞDAŞ DRAMA DERNEĞİ ADINA SAHİBI VE SORUMLU YAZI İŞLERİ MÜDÜRÜ/PUBLISHER AND CHIEF ON BEHALF OF CONTEMPORARY DRAMA ASSOCIATION \\ Zeki Özen (Çağdaş Drama Derneği Yönetim Kurulu Üyesi, zekioz@gmail.com)}

\section{EDITÖR/EDITOR}

Ferah Burgul Adıgüzel (Dr., Gazi Üniversitesi, fburgul@gmail.com)

\section{EDITTÖR YARDIMCISI}

İhsan Metinnam (Dr., Ankara Üniversitesi, ihsanmetinnam@gmail.com)

\section{İNGILIZCE DÜZELTME}

Abdullah Furkan Palabıyık (Okt., TED Üniversitesi, frknplb@gmail.com)

\section{YAYIN KURULU/EDITORIAL BOARD*}

Fatma Önalan Akfirat (Dr. Öğr. Üy., Yeditepe Üniversitesi)

Yaşare Aktaş Arnas (Prof. Dr., Çukurova Üniversitesi)

Murtaza Aykaç (Dr. Öğr. Üy., Niğde Üniversitesi)

Pınar Özdemir (Doç. Dr., Hacettepe Üniversitesi)

Ali Öztürk (Doç. Dr., Anadolu Üniversitesi)

*Soyadına göre alfabetik sıralanmıştır.

\section{Yönetim Yeri}

ÇDD Kocatepe Mah. Meşrutiyet Cad. Atıfbey Apt. 31/8 Kızılay - Ankara

Tel: (0-312) 4259192 Belgegeçer: (0-312) 4259192

Web: www.yader.org

Yazışma Adresi: ccddergi@gmail.com

Kocatepe Mah. Meşrutiyet Cad. Atıfbey Apt. 31/8 Kızılay - Ankara

Tel: (0-312) 4259192 Belgegeçer: (0-312) 4259192

E-posta: cdddergi@gmail.com

Yayınevinin adı: Pegem Akademi 


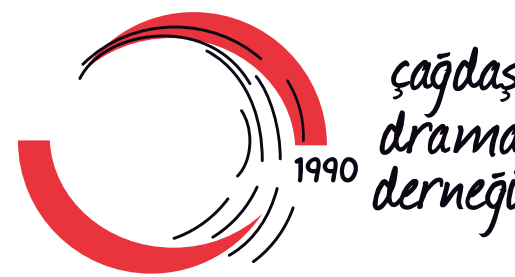

\section{Creative Drama Journal}
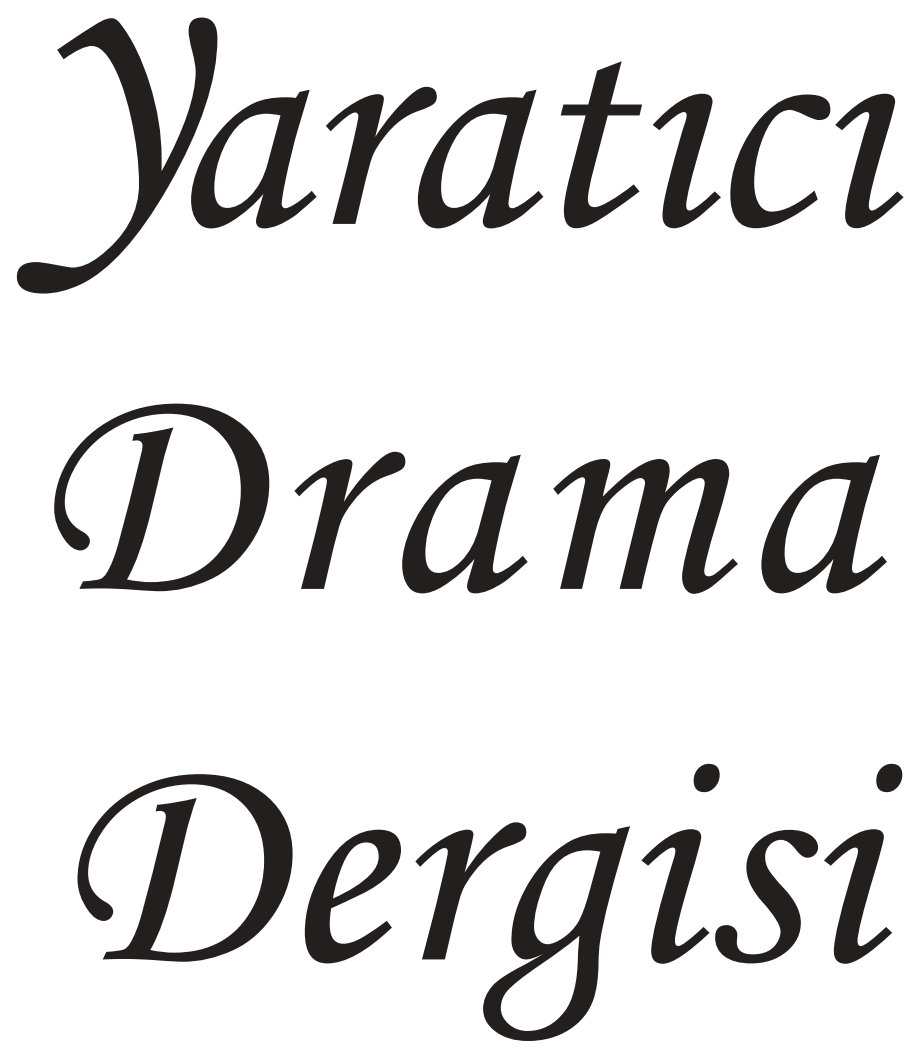
Yașare Aktaș Arnas (Prof. Dr., Cukurova Üniversitesi)

David Davis (Prof. Dr., Birmingham City Üniversitesi)

Mübeccel Gönen (Prof. Dr., Hacettepe Üniversitesi)

Sibel Güneysu (Prof. Dr., Başkent Üniversitesi)

Ayşe Çakır İlhan (Prof. Dr., Ankara Üniversitesi)

Gerd Koch (Prof. Dr., Berlin Alice Salomon Yüksek Okulu, Emekli Öğr. Üy.)

Nihal Kuyumcu (Doç. Dr., İstanbul Cerrahpaşa Üniversitesi)
Tamer Levent (Ankara Devlet Tiyatroları)

H. Wolfgang Nickel (Prof. Dr., Berlin GSÜ. Emekli. Öğr. Üy.)

Esra Ömeroğlu (Prof. Dr., Gazi Üniversitesi)

İnci San (Prof. Dr., Ankara Üniversitesi, Emekli Öğr. Üy.)

John Somers ( Exeter Üniversitesi, Emekli Öğr. Üy.)

*Soyadına göre alfabetik sırada/In alphabetical order

\section{HAKEM KURULU/REFEREE BOARD*}

Ömer Adıgüzel ( Prof. Dr., Ankara Üniversitesi) Ferah Burgul Adıgüzel (Dr., Gazi Üniversitesi) Fatma Önalan Akfirat (Dr.,Öğr. Üy., Yeditepe Üniversitesi)

O. Nejat Akfirat (Dr.,Öğr. Üy., Kocaeli Üni.) Berrin Akman (Prof.Dr. Hacettepe Üniversitesi) Hasan Akbulut (Prof. Dr., İstanbul Üniversitesi) Yaşare Aktaş Arnas (Prof. Dr., Çukurova Üniversitesi) İsmihan Artan (Prof. Dr., Hacettepe Üniversitesi) Necdet Aykaç (Doç. Dr., Muğla Üniversitesi) Murtaza Aykaç (Dr.,Öğr. Üy., Niğde Üniversitesi) Tuncer Bülbül (Prof. Dr., Trakya Üniversitesi) Pınar San Bayhan (Prof. Dr., Hacettepe Üniversitesi) Neval Akça Berk (Dr.,Öğr. Üy., Çukurova Üniversitesi) Nami Eren Beştepe (Dr.,Öğr. Üy., Ankara Üniversitesi) Selen Korad Birkiye (Doç. Dr., İstanbul Devlet Tiyatroları) Ahmet Çebi (Dr.,Öğr. Üy., On Dokuz Mayıs Üni.) Figen Çok (Prof. Dr., Başkent Üniversitesi) David Davis (Prof. Dr., Birmingham City Üniversitesi) Kenan Demir (Dr.,Öğr. Üy., Mehmet Akif Ersoy Üniversitesi) Celal Deha Doğan (Dr.,Öğr. Üy., Ankara Üniversitesi) Dagmar Dörger (Prof. Dr. Erfurt Üniversitesi) Tolga Erdoğan (Doç. Dr. Trabzon Üniversitesi) Stig A. Eriksson (Prof. Dr., Bergen Üniversitesi) Selahattin Gelbal (Prof. Dr., Hacettepe Üniversitesi) Mübeccel Gönen (Prof. Dr., Hacettepe Üniversitesi) Rezzan Gündoğdu (Doç. Dr., Aksaray Üniversitesi) Sibel Güneysu (Prof. Dr., Başkent Üniversitesi) İsmail Güven (Prof. Dr., Ankara Üniversitesi) Ulrike Hentschel (Prof. Dr., Berlin Güzel Sanatlar Üni.)
Ayşe Çakır İlhan (Prof. Dr., Ankara Üniversitesi)

Elif İskender (Dr.,Öğr. Üy., Dokuz Eylül Üniversitesi)

Oylum Akkuş İspir (Doç. Dr. Ohlone Üniversitesi)

Özlem Kaf (Dr.,Öğr. Üy., Çukurova Üniversitesi)

Ceren Karadeniz (Dr. Ankara Üniversitesi)

Serkan Keleşoğlu (Dr. Öğr.Üy., Ankara Üniversitesi)

Gerd Koch (Prof. Dr., Berlin Alice-SalomonYüksek Okulu) Müfit Kömleksiz (Prof. Dr., Lefke Avrupa Üniversitesi)

Ferda Öztürk Kömleksiz (Dr.,Öğr. Üy., Lefke Avrupa Üni.)

Ömer Kutlu (Dr.,Öğr. Üy., Ankara Üniversitesi)

Nihal Kuyumcu (Prof. Dr. İstanbul Cerrahpaşa Üniversitesi)

Hadiye Küçükkaragöz (Dr.,Öğr. Üy., Dokuz Eylül Üni.)

Laura A. McCammon (Prof. Dr., Arizona Üniversitesi)

İhsan Metinnam (Dr., Ankara Üniversitesi)

Ömer Nayci (Dr.,Öğr. Üy., Şırnak Üniversitesi)

H. Wolfgang Nickel (Prof. Dr., Berlin GSÜ Ü.Em.Öğ.Üy.)

Helen Nickholson (Dr., Royal Holloway Üniversitesi)

Mehmet Öcal Özbilgin (Prof. Dr., Ege Üniversitesi)

Ayşe Okvuran (Doç. Dr., Ankara Üniversitesi)

Anna-Lena Ostern (Prof. Dr., Bergen Üniversitesi)

John O’Toole (Prof. Dr., University of Melbourne)

Esra Ömeroğlu (Prof. Dr., Gazi Üniversitesi)

Pınar Özdemir Şimşek (Doç. Dr., Hacettepe Üniversitesi)

Ali Öztürk (Doç. Dr., Anadolu Üniversitesi)

Asuman Duatepe Paksu (Dr. Öğr. Üy., Pamukkale Üni.)

İnci San (Prof. Dr., Ankara Üniversitesi, Emekli Öğr. Üy.)

John Somers (Emekli Öğr. Üy., Exeter Üniversitesi)

Ülker Şen (Doç.Dr., Gazi Üniversitesi)

Özlem Ünal (Dr., Hacettepe Üniversitesi)

Tülay Üstündağ (Dr., Hacettepe Üniversitesi Emekli Öğr. Elm.)

Florian Vaßen (Prof. Dr., Hannover Ün. Emekli Öğr. Üy.)

\section{BU SAYININ HAKEMLERI / JUDGES OF THIS ISSUE}

\footnotetext{
Ömer Adıgüzel (Prof. Dr., Ankara Üniversitesi)

Ferah Burgul Adıgüzel (Dr., Gazi Üniversitesi)

Necdet Aykaç (Doç. Dr. Muğla Sıtkı Koçman Üniversitesi)

Nami Eren Beştepe (Dr. Öğr. Üy., Ankara Üniversitesi)

Serkan Keleşoğlu (Dr. Öğr. Üy., Ankara Üniversitesi)

İhsan Metinnam (Dr., Ankara Üniversitesi)
}

\section{* Soyadina göre alfabetik sirada/In alphabetical order}

Ömer Nayci (Dr. Öğr. Üy., Şırnak Üniversitesi)

Zeki Özen (Dr., Ankara Üniversitesi)

Ali Öztürk (Doç. Dr., Anadolu Üniversitesi)

Ülker Şen (Doç. Dr., Gazi Üniversitesi)

Pınar Özdemir Şimşek (Doç. Dr., Hacettepe Üniversitesi) 
Editörden iv

Araştırma Makaleleri

Güzel Sanatlar Eğitim alanı Olarak Yaratıcı Dramanın MEB ve YÖK Programlarındaki Görünümü

Ömer Adıg̈̈zel, Gizem Sivrikaya. 203

Sınıf Öğretmenliği Adaylarının Yaratıcı Drama Oturumu Planlama Sürecinde Yaşadıkları Sorunların İncelenmesi

İhsan Metinnam 219

Teaching adolescents Civil Law: Process Drama as a tool for achieving Legal Literacy

Antigoni Laskaridou, Alkistis Kontoyianni,

Christina Zoniou, Asterios Tsiaras.

Müzede Sosyal Bilgiler Öğretiminde Yaratıcı Dramanın Bir Yöntem Olarak Kullanımına İlişkin Uzman Görüşleri

Merve Ulu, Ferah Burgul Adıgüzel . 263

Çocuk ve Drama Dersi Veren Öğretim Elemanlarının

Niteliklerine İlişkin Çocuk Gelişimi Programı

Öğrencilerinin Görüşleri

Ömer Nayci.....

Masal Anlatımının İlkokul 4. Sınıf Öğrencilerinin

Konuşma Prozodilerine Etkisi

Fatih Çetin Çetinkaya, Muhammet Sönmez

Promoting the acceptance of the 'other' through Drama in Education

Theodora Papaioannou, Alkistis Kondoyianni . 309

\section{Görüş Yazısı}

Working in Role: Teachers and Children

Patrice Baldwin.

Yaratıcı Drama Dergisine İlişkin Açıklamalar ve Yazım Kuralları
Editorial V

Research Article

How Creative Drama, Which is a Field of Fine Arts Education, is Presented in MoNE and HEC Curriculums

Ömer Adıgüzel, Gizem Sivrikaya. 204

Investigation of the Problems of Primary School Teacher Candidates in the Planning Process of Creative Drama Session

İhsan Metinnam 220

Gençlere Medeni Kanunu Öğretmek: Hukuk

Okuryazarlığı Eğitiminde Süreçsel Dramanın Bir Araç Olarak Kullanımı

Antigoni Laskaridou, Alkistis Kontoyianni,

Christina Zoniou, Asterios Tsiaras.

Opinions of the Experts on Employing Creative Drama as a Method in Social Studies Teaching in the Museum

Merve Ulu, Ferah Burgul Adigüzel . 264

The Opinions of Child Development Programme Students Related to the Qualifications of Instructors Teaching Child and Drama Lesson

Ömer Nayci 282

The Effect of Fairy Tales on the Prosody of Primary School 4th Grade Students

Fatih Çetin Çetinkaya, Muhammet Sönmez 297

Eğitimde Drama İle ‘Ötekinin’ Kabulünü Teşvik Etmek

Theodora Papaioannou, Alkistis Kondoyianni ..... 309

The Letter of Opinion

Rol İçinde Çalışma: Öğretmenler ve Çocuklar

Patrice Baldwin.

Submission Guidelines for Creative

Drama Journal 331 


\section{Editörden}

Yaratıı Drama Dergisinin 14. cilt 2. sayısında yeni çalışmalarla yine sizlerle olmaktan mutluluk duyuyoruz. Dergimizin bu sayısında da yaratıcı drama alanında yapılan farklı disiplinlerden ulusal ve uluslararası çalışmalara yer veriyoruz. Bu sayımızda yer alan çalışmalarda YÖK'ün ve MEB'in yaratıcı drama yaklaşımları değerlendirilmiş, yaratıcı dramayla ders planlama sürecinde yaşanılan sorunlar ele alınmış, eğitmenlerin sosyal adalet tutumları incelenmiş, uzmanlara tarafindan müzede sosyal bilgiler eğitiminde yaratıcı drama yönteminin kullanımı değerlendirilmiş, yaratıı drama dersi veren öğretim elemanlarının nitelikleri irdelenerek rol içinde çalışmanın özelliklerine yer verilmiştir.

Dergimizin bu sayısında; Ömer Adıgüzel ve Gizem Sivrikayànın Güzel Sanatlar Eğitim Alanı Olarak Yaratıcı Dramanın MEB ve YÖK Programlarındaki Görünümü, İhsan Metinnamin Sını Öğretmenliği Adaylarının Yaratıcı Drama Oturumu Planlama Sürecinde Yaşadıkları Sorunların İncelenmesi, Antigoni Laskaridou, Alkistis Kontoyianni, Christina Zoniou ve Asterios Tsiaras’n Gençlere Medeni Kanunu Öğretmek: Hukuk Okuryazarlı̆ı̆ Eğitiminde Süreçsel Dramanın Bir Araç Olarak Kullanımı, Merve Ulu ve Ferah Burgul Adıgüzel’ in Müzede Sosyal Bilgiler Öğretiminde Yaratıcı Dramanın Bir Yöntem Olarak Kullanımına İlişkin Uzman Görüşleri, Ömer Naycinnin Çocuk ve Drama Dersi Veren Öğretim Elemanlarının Niteliklerine İlişkin Çocuk Gelişimi Programı Öğrencilerinin Görüşleri, Fatih Çetin Çetinkaya ve Muhammet Sönmez’in Masal Anlatımının İlkokul 4. Sını Öğrencilerinin Konuşma Prozodilerine Etkisi, Theodora Papaioannou ve Alkistis Kondoyianni’nin Eğitimde Drama ile ‘Ötekinin’ Kabulünü Teşvik Etmek adl makalelerine ve Patrice Baldwin’in Working in Role - Teachers and Children adl görüş yazısına yer verilmiştir.

Dergimizin bu sayısını da yaratıcı drama alanında yapılan yeni çalışmalar açısından değerlendirerek alanımızın ve bireysel olarak eğitmenlik boyutumuzun farklı alanlarla etkileşimi açısından yayınlarımızı takip etmenizi diliyoruz. Bu sayımızı çalışmalarıyla destekleyen yazarlarımıza, titizlikle değerlendirme yapan hakemlerimize ve emeği geçenlere çok teşekkür ediyor, sizlerin de çabamıza ortak olmanızı bekliyoruz.

Yaratıcı drama alanına katkı sağlamak amacıyla yapılacak yeni araştırma ve projelerin yer alacağı 2020 yılının ilk sayısinda buluşmak dileğigle...

\section{Dr. Ferah Burgul Adigüzel}

Editör 


\section{Editorial}

It is with great pleasure to introduce you to the issue 2 of the volume 14 of Creative Drama Journal. We continue to include national and international works of different disciplines produced in the field of creative drama in this issue of our journal. The works in this issue of our journal; evaluate the creative drama approaches of The Higher Education Institution and Ministry of National Education, focus on the problems faced in creative drama curriculums, examine the employment of creative drama method by the experts in social studies education in museums, and include the features of working in the role by questioning the qualifications of the creative drama instructors.

In this new issue of our journal you will have a chance to read these articles: Apperance of the Creative Drama as a Field of Fine Arts Education in the Curriculums of Ministry of National Education and the Higher Education Institution by Ömer Adıgüzel and Gizem Sivrikaya, Examining the Problems Faced by the Classroom Teacher Applicants During the Process of Creative Drama Session Planning by İhsan Metinnam, Teaching adolescents Civil Law: Process Drama as a tool for achieving Legal Literacy by Antigoni Laskaridou, Alkistis Kontoyianni, Christina Zoniou and Asterios Tsiaras, Opinions of the Experts on Employing Creative Drama as a Method in Social Studies Teaching in the Musem by Merve Ulu ve Ferah Burgul Adrgüzel, Opinions of the Child Development Program Students on the Qualifications of the Instructors of Child and Drama Lesson by Ömer Nayci, The Effect of Fairy Tales on the Prosody of Primary School 4th Grade Students by Fatih Çetin Çetinkaya and Muhammet Sönmez, Promoting the acceptance of the 'other' through Drama in Education by Theodora Papaioannou and Alkistis Kondoyianni and Working in Role - Teachers and Children the letter of opinion by the Patrice Baldwin.

We wish that you will follow our publications with regards to the interaction of our instructor aspect and creative drama fields individually with different fields of study by evaluating this issue of our Journal from the viewpoint of new studies carried out in the field of creative drama. We would like to thank our authors, who supported this issue with their works, our reviewers, who meticulously evaluated these works, and those who contributed, we wish you to join our efforts, as well.

We wish to see you in the first issue of 2020 which will include new studies and projects to be carried out with the purpose of contributing to the field of creative drama...

\section{PhD. Ferah Burgul Adgüzel}

\section{Editor}





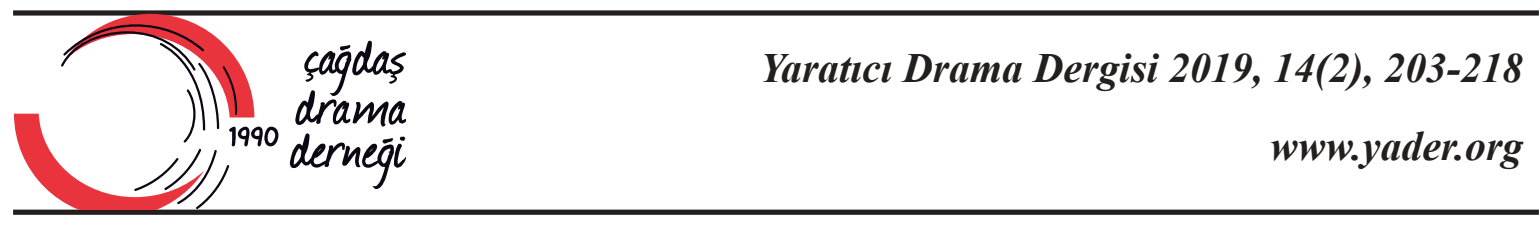

\title{
Güzel Sanatlar Eğitim Alanı Olarak Yaratıcı Dramanın MEB ve YÖK Programlarındaki Görünümü
}

\author{
Ömer Adıgüzel ${ }^{1}$ \\ Gizem Sivrikaya $^{2}$
}

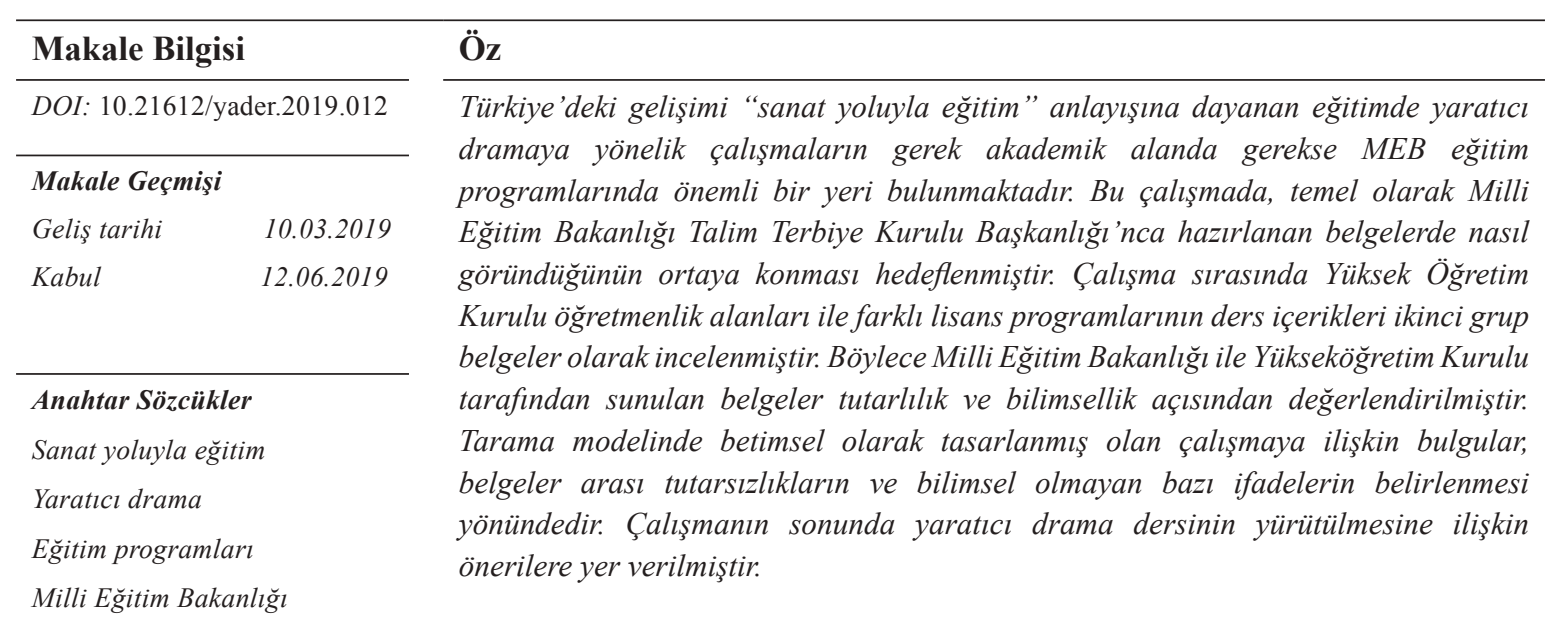

Yüksekögretim Kurulu

Makale Türü

Araştırma Makalesi

1 Prof Dr, Ankara Üniversitesi Eğitim Bilimleri Fakültesi, Ankara, Türkiye. E-Posta: omeradiguzel@gmail.com. Orcid ID: https://orcid.org/0000-0001-9492-6231

2 Bil. Uzm., Ankara Üniversitesi Güzel Sanatlar Fakültesi, Ankara, Türkiye. E-posta: gizemsivrikaya55@gmail.com. Orcid ID: https://orcid.org/0000-0002-5923-785X 


\section{How Creative Drama, Which is a Field of Fine Arts Education, is Presented in MoNE and HEC Curriculums}

\begin{tabular}{lr}
\hline Article Info \\
\hline DOI: $10.21612 /$ yader.2019.012 \\
\hline Article History & \\
Received & 10.03 .2019 \\
Accepted & 12.06 .2019 \\
& \\
\end{tabular}

Keywords

Education through arts

Creative drama

Educational programmes

Ministry of Education

Higher Education Council

\begin{abstract}
Creative drama which has been developed in Turkey based on the understanding of "education through arts" has a place both in academic life and formal educational system. In this study, it is aimed to draw a picture of creative drama by using documents presented by Board of Education and Discipline, which is one of the departments of Ministry of Education. During the study, it was recognized that a picture of creative drama needs some other documents related to different bachelor educational programmes' content, which are confirmed by Higher Education Council, so these documents was also reached by researchers as a second data set of the study. In this way, the consistency among documents prepared by Ministry of Education and Higher Education Council and their scientificness was evaluated. The findings of the study which is an example of a descriptive study and designed based on a survey model, says that there are some inconsistencies among the documents. Also, there are some unscientific expressions on them. Based on the findings, the issue will be discussed and some suggestions will be presented.
\end{abstract}

Article Type

Research paper 


\section{Giriş}

Drama dersi İngiltere'de, ifade ve öğrenmede sanatın temel alan olduğu görüşü ile ortaya çıkmış; doğaçlamaya dayalı etkinliklerin tiyatrodan farkını belirtmek için bu alan Eğitimde Drama (Drama in Education) veya Eğitsel Drama (Educational Drama) ismiyle anılmıştır (Somers, 2012). Diğer yandan aynı alan ABD, Avustralya, Yeni Zelanda, Kanada gibi ülkelerde de yaratıcı drama (Creative Drama) olarak adlandırılmış ve geliştirilmiştir. Türkiye alan yazınında ise "Drama, Eğitimde Drama, Yaratıcı Drama” kavramlarının kullanıldığı görülmektedir (Adıgüzel, 2008).

Drama, eğitimde drama veya yaratıcı drama çalışmalarının Türkiye'de özellikle akademik ortamda ele alınmaya başlaması 1980'li yıllara kadar uzanır. Bu yıllar ülkemizde drama alanındaki yeni bilimsel bakış ve araştırmaların yoğunlaştığı, dramanın bir yöntem, başlı başına bir ders olarak sistemde yer aramaya başladığı dönem olarak anılmaktadır (Adıgüzel, 2019). Bu başlangıçta Ankara Üniversitesi Eğitim Bilimleri Fakültesi Güzel Sanatlar Eğitimi alanından İnci San ile Devlet Tiyatroları sanatçılarından Tamer Levent'in buluşmalarının yaratıcı dramanın (Eğitimde Drama, Yaratıcı Drama) Türkiye'deki gelişimi adına önemli olduğu görülmektedir.

Yaratıcı dramanın Türkiye'deki gelişiminde önemli bir yer tutan San, bu alanla olan bağının temel olarak sanat eğitimi ve sanat eğitim bilimi alanlarına yönelik bilgi birikiminden doğduğunu; sanat eğitiminin önemli bir parçası olan yaratıcı dramanın diğer birçok sanat dalından daha etkili olduğunu gözlemlediğini ifade eder (Başbuğ, 2006). Levent ise yaratıcı dramanın yaşamın her alanında kullanılması gerektiğini, yaratıcı drama sayesinde kişinin kendisi ve başkaları arasındaki benzerlik ve farklılıkları ayırt edebileceğini, bunun bir farkındalık eğitimi olarak demokrasi kültürü adına önemli bir unsur olduğunu belirtir (Adıgüzel, 2019, s.254).

Bowell ve Heap (2013) okuldaki deneyimin asıl kaynağının, öğretmen veya kitap, dergi, yayın gibi kullanılan kaynaklar olduğunu ifade etmiş; dolayısıyla öğrenme yaşantısına başka biri veya bir şey aracılığıyla ikinci elden ulaşıldığını belirtmişlerdir. Yazarların bu geleneksel ortama ilişkin belirlemeleri, duyuşsal dünya ile bilişsel dünya arasına bir çizgi çekildiği; bu ortamda hisler ile düşüncelerin birbirinden ayrıldığı şeklinde olmuştur. Belirtilen ayrım, sürece şu şekilde yansır: Öğrencinin bilgiyi anlamlı ve kullanılır hale getirme olasılığı azalır. Hâlbuki bilginin kullanışlı hale getirilebilmesinde hislerin rolü büyüktür. Belirtilen bir ortamda bunun nasıl aşılabileceği sorusuna yanıt yaratıcı dramanın nasıl gerçekleştiğine yönelik açıklamadan yola çıkarak verilebilir.

Yaratıcı dramada canlandırmalar esastır. Hatta yaratıcı dramayı diğer etkileşimli öğrenme yöntemlerinden ayıran en temel fark budur. Canlandırmalar sırasında dramanın kendine özgü teknikleri (doğaçlama, rol oynama, rol değiştirme, rol içinde yazma, öğretmenin role girmesi, donuk imge vd.) kullanılır. Yaratıcı dramanın teknikleriyle birlikte canlandırmaların kullanılmasıyla öğrenme daha yaşantısal hale getirilebilir. Böylece bireydeki tüm bilişsel, duyuşsal ve devinişsel davranış alanları geliştirilebilir. Yaratıcı drama, özellikle okullardaki çeşitli öğrenim basamaklarında çocuğa kendini tanımayı, yeti ve yeteneklerini keşfetmeyi, grup arkadaşlarını tanımayı, kendini onların yerine koyabilmeyi, bir olgu ya da çeşitli yönleriyle irdelemeyi, oynayarak, yaşayarak öğrenmeyi sağlayabilir (Adıgüzel, 2019). Dolayısıyla yaratıcı dramanın, öğrenme sürecinde edinilen bilginin anlamlı ve kalıcı hale getirilmesinde bir kapı araladı̆̆ı söylenebilir.

Türkiye'de yaratıcı drama alanının eğitim-öğretim programlarındaki yerine bakıldığında, akademik düzeyindeki ilk çalışmaların 1990 yılında Ankara Üniversitesi Güzel Sanatlar Eğitimi 
Anabilim Dalı'nda açılan ilk "Eğitimde Yaratıcı Drama" dersi olduğu söylenebilir. Yaratıcı Drama Yüksek Lisans programı Ankara Üniversitesi’nde 1999 yılında açılır. Anadolu Üniversitesi Eğitim Bilimleri Enstitüsü ise Eğitimde Drama Anabilim Dalı'nı kurarak 2007 yılında eğitime başlar.

Milli Eğitim Bakanlığı tarafından ilköğretim ve ortaöğretimde drama dersi olarak yapılan çalışmaların 1998 yılında Milli Eğitim Bakanlığı Talim ve Terbiye Kurulu Başkanlığı'nın İlköğretim Okulları Seçmeli Drama Dersi 1-2-3 Öğretim Programının oluşturması ile başladığı görülür. 1999 yılında bu programla eş zamanlı olarak öğretmenlere yönelik olan "Drama 1" başlıklı öğretmen el kitabı yayınlanmıştır. 2005 ve sonrasındaki yıllarda yapılan değişiklik ve gelişmelerle yaratıcı dramanın öğretim programlarında yer aldığı belirtilmiştir (Adıgüzel, 2008).

Son olarak uygulamaya konulan Drama Dersi Öğretim Programı, Talim Terbiye Kurulu'nun 13.06.2018 tarih ve 82 sayılı kararı ile onaylanmış ve uygulamaya sunulmuştur. Bu program ile ilköğretim 5. ve 6. sınıflarda drama seçimlik bir ders olarak yer almaktadır. Ortaöğretim programlarında ise drama dersi Anadolu Liselerinin 9-12 sınıflarında birer saat olmak üzere seçimlik, Sosyal Bilimler Liselerinde 9. sinıflarda ve Fen Liselerinde 9-12. sınıflarda seçimlik olarak yer almaktadır. Güzel Sanatlar Liseleri Müzik Ağırlıklı Programda 12. sınıfta ortak ders, Görsel Sanatlar Programında 12. sınıf, Türk Halk Müziği ve Türk Sanat Müziği Programlarında 11. sınıf, Spor Liselerinde 11 ve 12. sinıflarda, İmam Hatip Liselerinde 10. 11. ve 12. sinıflarda 1 veya 2 saat ve seçimlik olarak, özel temel liselerin 12. sınıflarında ise bir saat ve seçimlik olarak drama dersleri yer almaktadır (Talim Terbiye Kurulu, 2018).

Yaratıcı drama alanı ile ilgili olarak atılan adımların bilimsel üretimle uyumlu ve birbirini destekleyen bir ilişki içerisinde olması gerekir. Bu nedenle yaratıcı drama kavramına, programına veya dersine ilişkin olarak MEB ve YÖK tarafından alınan kararların ve yapılan çalışmaların değerlendirilmesi önemli bir gereksinim oluşturmaktadır. Bu gereksinimden yola çıkarak bu çalışmada, Milli Eğitim Bakanlığı ve Yükseköğretim Kurulu'nun drama alanında yaptığı son çalışmalar gözden geçirilmiş, alanla ilgili düzenlemelerin drama alanı çerçevesindeki tutarlılığının incelenmesi amaçlanmıştır. Belirtilen amaç doğrultusunda şu araştırma sorularına yanıt aranmıştır:

1. Drama, Milli Eğitim Bakanlığı ve Yüksek Öğretim Programlarında nasıl yer almakta, hangi atama alanlarında ele alınmaktadır?

2. Milli Eğitim Bakanlığı ve Yüksek Öğretim Programlarında drama öğretmenliği yapabilmeye ilişkin ölçütler belirtilmiş midir, belirtilmişse bu ölçütler nelerdir?

\section{Yöntem}

Araştırma, bir durumu olduğu haliyle betimlemeyi amaçlayan tarama modelinde (Karasar, 2015) tasarlanmıştır. Doküman inceleme yoluyla gerçekleştirilen çalışma için gerekli olan belgeler araştırma için belirlenen problemlerden yola çıkarak saptanmıştır. Dolayısıyla araştırma çerçevesinin de böylece belirlendiği söylenebilir. Drama öğretmenliğine ilişkin olarak alınan kararların Talim Terbiye Kurulu tarafindan sunulması nedeniyle Talim Terbiye Kurulu Başkanlığı tarafından oluşturulan ve en son 22/02/2019 tarihli ve 4 sayılı Kurul Kararı, Mart 2019-2738 sayılı Tebliğler Dergisi'nde yer alan Öğretmenlik Alanları, Atama ve Ders Okutma Esasları başlıklı belge temel olarak incelenmiştir. İncelenen ikincil belgeler ise Milli Eğitim Bakanlığı İlköğretim; Orta Öğretim Haftalık Ders Çizelgeleri ile Yükseköğretim Kurulu Öğretmen Yetiştirme Lisans Programlarıdır. 
Belge incelenen çalışmalarda araştırmacının belgenin tarihi, orijinal olup olmama durumu, belgenin tamamına ulaş11ıp ulaşılamaması (Guba ve Lincoln 1981'den akt. Merriam, 2013) gibi sorulara yanıt vermenin araştırmacının sorumluluğunda olduğu belirtilmiştir. Bu araştırmada, incelenen belgelere ilişkin tarih ve orijinal olma durumları belirtilmiş olup araştırmacıların kullanılan belgelere ilişkin sorumluluğu aldığı ifade edilmelidir. İncelenen dokümanlara kurumun kendi çevrimiçi kaynağından ulaşı1mıştır. Doküman orijinal, tamamına ulaşılabilir nitelikte erişime açıktır. Araştırma sorularının güncel bir duruma yönelik saptamaya ilişkin olması sebebiyle belgenin duruma ilişkin en son karar olması gerekmektedir. Bu sebeple araştırmacılar Talim Terbiye Kurulu Başkanlığı'nın ilgili kararlarını ve haftalık ders programlarını inceleyip güncel kaynağa ulaşmışlardır. Böylelikle araştırmacıların veri kaynağına ilişkin sorumluluklarını yerine getirdiği söylenebilir.

Diğer yandan bu araştırma çerçevesinde temel olarak belirlenen belgede drama öğretmenliğ $i$ yapabileceği belirtilen bölümlerin eğitim programları içerikleri de gözden geçirilmiştir. $\mathrm{Bu}$ doğrultuda incelenen ikinci grup belgeler ise şunlardır: YÖK Türkçe Öğretmenliği Lisans Ĕgitim Programı; Türk Dili ve Edebiyatı Öğretmenliği Lisans Eğitim Programı; Drama ve Oyunculuk lisans eğitim Programlarl; Drama ve Oyunculuk Lisans Eğitim Programları. Araştırmacıların, belirtilen veri kaynağı grubuna ilişkin güncellik, orijinallik ve belgenin tamamına ulaşıp ulaşmama sorumluluklarını yerine getirdiği söylenebilir. İncelenen temel belgede olduğu gibi bu belgeye erişim de Yükseköğretim Kurulu'nun resmi internet sitesinden açık erişim aracılığıyla sağlanmıştır.

Dokümanlar incelenirken anahtar sözcük olarak "drama” sözcüğü hem bilgisayar ortamında hem de manuel olarak taranmıştır. Anahtar sözcüğün bulunduğu madde, tümce veya paragraflar ve bu unsurların birbiri ile bağlantısı belgeler arası tutarlılık ve alan yazınla uyumlu olma temelinde incelenmiştir. Araştırmacılardan birinin çeşitli uluslararası drama kuruluşlarına üye olan bir derneğin yönetim kurulunda olmasını, yaratıcı drama alanında üniversite öğretim üyeliği ile birlikte alanla ilgili kapsamlı yayınlar yapmasını ve aynı zamanda uygulayıcı olmasını, diğerinin de yaratıcı drama eğitimi programını almış olmasını, belgelerin incelenmesi sırasında alanla ilgili var olan durumun belirlenebilmesinde ve eksikliklerin saptanabilmesinde gerekli uzmanlık bilgisine sahip olduklarını göstermesi açısından önemlidir.

\section{Bulgular ve Yorumlar}

\section{Milli Eğitim Bakanlığı ve Yükseköğretim Kurulu Programlarında Drama ve Atamaya Esas Olan Alan}

Milli Eğitim Bakanlığı Talim Terbiye Kurulu Başkanlığı tarafından oluşturulan ve en son 22/02/2019 tarihli ve 4 sayılı Kurul Kararı, Mart 2019-2738 sayılı Tebliğler Dergisi'nde yer alan Öğretmenlik Alanları, Atama ve Ders Okutma Esasları başlıklı belge incelendiğinde Drama ile Drama ve Oyunculuk'un atamaya esas alan olarak Eğlence Hizmetleri başlı̆̆ 1 altında yer aldığ görülmektedir (Görsel 1). Bu belirlemenin, drama alanının bir eğlence hizmeti olduğu izlenimini doğurduğu söylenebilir. 


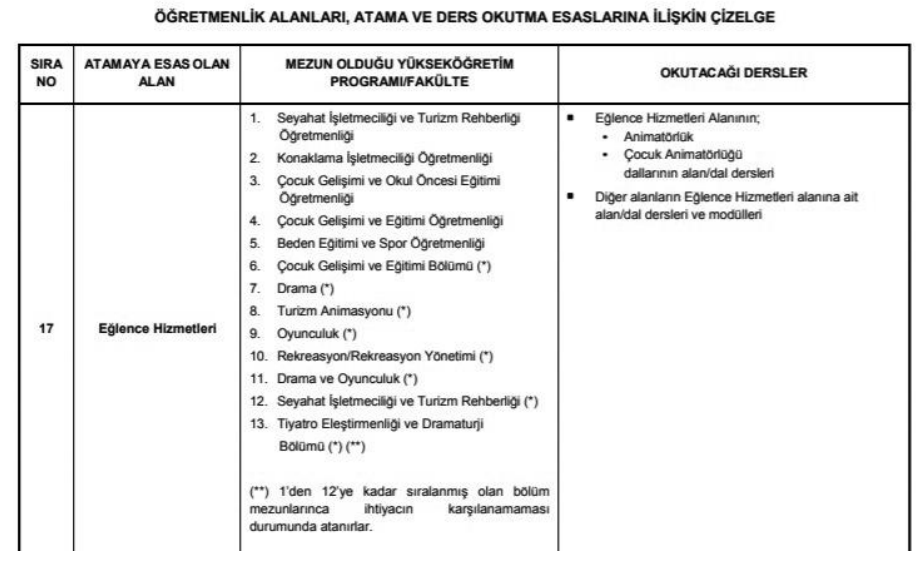

Görsel 1. Tebliğler Dergisi Mart 2019- Öğretmenlik Alanları, Atama ve Ders Okutma Esaslarına Illişkin Çizelge'de Drama 'nın Ĕ̆lence Hizmetleri başlı̆̆ altında ele alındiğı görülmektedir.

Diğer yandan Milli Eğitim Bakanlığı'nın tüm eğitim kademelerine yönelik olarak hazırladığı Haftalık Ders Çizelgeleri incelendiğinde (İlköğretim Haftalık Ders Çizelgesi, Anadolu Liseleri, Fen Liseleri, Sosyal Bilimler Liseleri, Güzel Sanatlar Liseleri ve İmam Hatip Liseleri Haftalık Ders Çizelgeleri) Drama dersinin Görsel Sanatlar, Müzik, Sanat Tarihi gibi bir güzel sanatlar eğitimi alanı olarak tanımlandığı görülmektedir (Görsel 2; Görsel 3; Görsel 4; Görsel 5; Görsel 6).

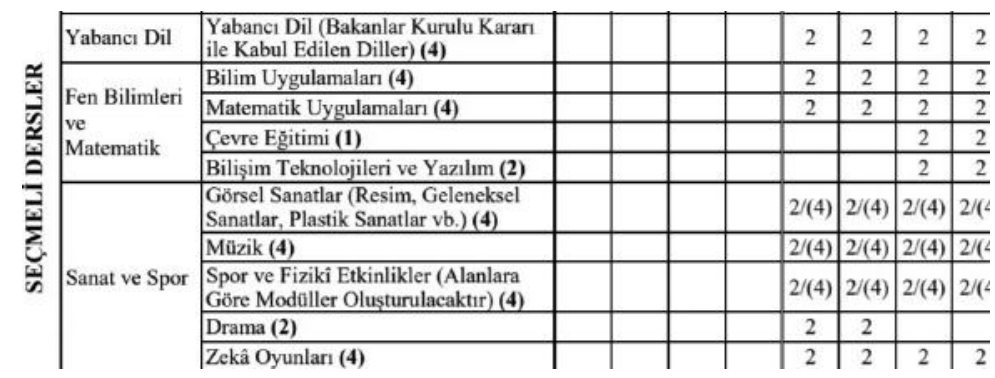

Görsel 2. 2018-2019 Ĕgitim Öğretim Yılı İlköğretim Haftalık Ders Çizelgesi Seçmeli Dersler Sanat ve Spor Grubuna Illişkin Görüntü'de Drama!nın Sanat alanı olarak anıldığı görülmektedir.

\begin{tabular}{|c|c|c|c|c|c|}
\hline \multirow{2}{*}{$\begin{array}{c}\text { SPOR VE } \\
\text { SOSYAL } \\
\text { ETKINLIK }\end{array}$} & SEÇMELI BEDEN EĞiTIMI VE SPOR (4) & 2 & 2 & 2 & 2 \\
\hline & SOSYAL ETKINLIK (4) & $(1)(2)$ & $(1)(2)$ & $(1)(2)$ & (1)(2) \\
\hline \multirow{4}{*}{$\begin{array}{c}\text { GŪZEL } \\
\text { SANATLAR }\end{array}$} & SEÇMELI GÖRSEL SANATLAR (4) & 2 & 2 & 2 & 2 \\
\hline & SEÇMELi MÜZiK (4) & 2 & 2 & 2 & 2 \\
\hline & SANAT TARIHI (1) & 2 & 2 & 2 & 2 \\
\hline & \begin{tabular}{|l}
$\operatorname{DRAMA}(1)$ \\
\end{tabular} & 1 & 1 & 1 & 1 \\
\hline \multirow{2}{*}{ BiLișisim } & BILGISAYAR BILIMII (2) & 2 & 2 & 2 & 2 \\
\hline & PROJE HAZIRLAMA (1) & $(1)(2)$ & $(1)(2)$ & $(1)(2)$ & (1)(2) \\
\hline
\end{tabular}

Görsel 3. 2018-2019 Ĕgitim Öğretim Yılı Anadolu Lisesi Haftalık Ders Çizelgesi Seçmeli Ders Programı Güzel Sanatlar Derslerine Illişkin Görüntü’de Drama!nın Güzel Sanatlar alanı olarak anıldı̆̆ı görülmektedir. 
Güzel Sanatlar Eğitim Alanı Olarak Yaratıcı Dramanın MEB ve YÖK Programlarındaki Görünümü

\begin{tabular}{c|l|c|c|c|}
$\begin{array}{c}\text { SPOR VE } \\
\text { SOSYAL } \\
\text { ETKINLIK }\end{array}$ & SEÇMELI BEDEN EGITIMI VE SPOR (2) & - & $(1)(2)$ & $(1)(2)$ \\
\cline { 2 - 5 } & SOSYAL ETKINLIK (2) & - & $(1)(2)$ & $(1)(2)$ \\
\hline \multirow{2}{*}{$\begin{array}{c}\text { GÜZEL } \\
\text { SANATLAR }\end{array}$} & SEÇMELI GÖRSEL SANATLAR (3) & $(1)(2)$ & $(1)(2)$ & $(1)(2)$ \\
\cline { 2 - 5 } & SEÇMELI MÜZIK (3) & $(1)(2)$ & $(1)(2)$ & $(1)(2)$ \\
\cline { 2 - 5 } & SANAT TARIHI (1) & - & $(1)(2)$ & $(1)(2)$ \\
\cline { 2 - 5 } & DRAMA (3) & - & $(1)(2)$ & $(1)(2)$ \\
\hline \multirow{2}{*}{ BILIŞSiM } & BILGISAYAR BILIMI (2) & - & $(1)(2)$ & $(1)(2)$ \\
\cline { 2 - 5 } & PROJE HAZIRLAMA (1) & - & $(2)$ \\
\hline
\end{tabular}

Görsel 4. 2018-2019 Ĕ̆itim Öğretim Yılı Anadolu Imam Hatip Lisesi Haftalık Ders Çizelgesi Seçmeli Ders Programı Güzel Sanatlar Derslerine Ilişsin Görüntü'de Drama'nın Güzel Sanatlar alanı olarak anıldı̆̆ı görülmektedir .

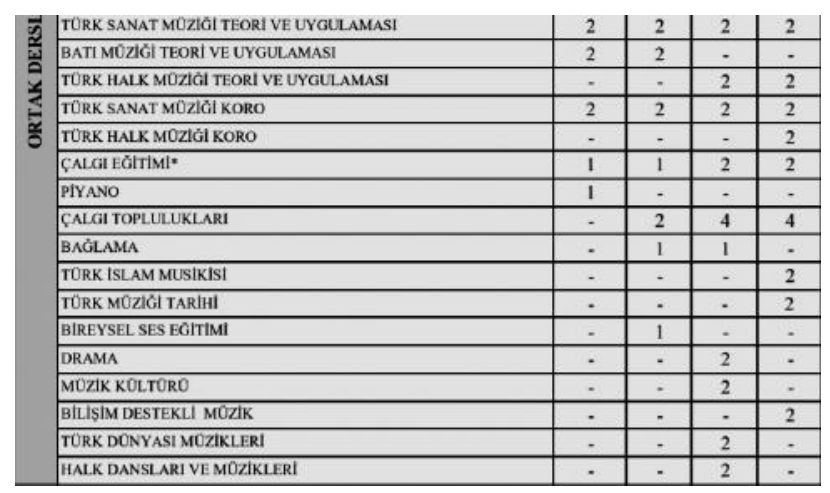

Görsel 5. 2018-2019 Ĕ̌itim Öğretim Yılı Güzel Sanatlar Lisesi (Türk Sanat Müziği) Haftalık Ders Çizelgesi Sanatsal Ortak Derslere İlişkin Görüntü'de Drama'nın Güzel Sanatlar alanları ile birlikte ele alındiğı görülmektedir.

\begin{tabular}{|l|c|c|c|c|}
\hline DESEN & 4 & 4 & 4 & 4 \\
\hline IKI BOYUTUU SANAT ATÓLYE & - & 4 & 4 & 4 \\
\hline OÇ BOYUTLU SANAT ATÓLYE & - & - & 4 & 4 \\
\hline TEMEL SANAT EÖITIMI & 4 & - & - & - \\
\hline MOZZ EGIIIMI & - & - & - & 2 \\
\hline GENEL SANAT TARIHI & - & 2 & - & - \\
\hline GRAFIK TASARIM & - & - & 4 & - \\
\hline DRAMA & - & - & - & 2 \\
\hline CAĞDAS DONYA SANATITARIHI & - & - & - & 2 \\
\hline ESTETIK & - & - & 2 & - \\
\hline SANAT ESERLERI ANALLZI & - & - & - & 2 \\
\hline TORK ISLAM SANATI TARIHI & - & - & 2 & - \\
\hline GELENEKSELTORK SANATLARI MINYATOR & - & - & 2 & - \\
\hline GELENEKSELTORK SANATLARI EBRU & - & - & - & 2 \\
\hline IMGESEL RESIM & - & 2 & 2 & 2 \\
\hline
\end{tabular}

Görsel 6. 2018-2019 Eğitim Öğretim Yılı Güzel Sanatlar Lisesi (Görsel Sanatlar) Haftalık Ders Çizelgesi Sanatsal Ortak Derslere İlişkin Görüntü'de Drama'nın Güzel Sanatlar alanları ile birlikte ele alındı̆̆ görülmektedir.

Bunun yanı sıra Tebliğler Dergisi'nin Eylül 2018-2732 sayısı gözden geçirildiğinde Drama dersinin, Görsel 2'de belirtilen alanlardan bazılarını da kapsayacak şekilde sanat başlı̆̆ altında ele alındığı görülmektedir (Görsel 7). 


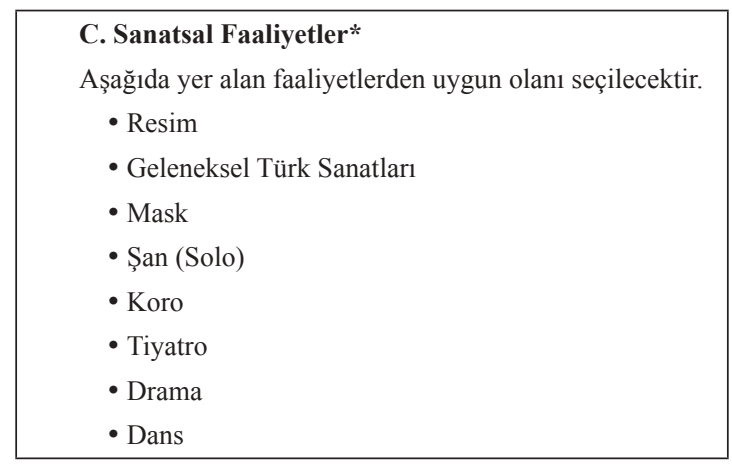

Görsel 7. Tebliğler Dergisi Eylül 2018- Sosyal Etkinlikler Dersi Kapsamında Yer Alan Faaliyetler/Sanatsal Faaliyetlere ilişkin Görüntü'de Drama alanının sanatsal bir faaliyet olarak ele alındı̆̆ görülmektedir.

Benzer bir şekilde Yükseköğretim Kurulu Başkanlığı'nın 10.09.2008 tarihli Eğitim Fakültelerine İlişkin Öğretmen Yetiştirme Türk Milli Komitesi kararında yaratıcı dramanın; görsel sanatlar-heykel, resim, müzik, tiyatro ve pantomim alanlarıyla birlikte Eğitim Fakültelerinin Güzel Sanatlar Eğitimi Bölümü altında ele alındığı görülmektedir (Görsel 8).

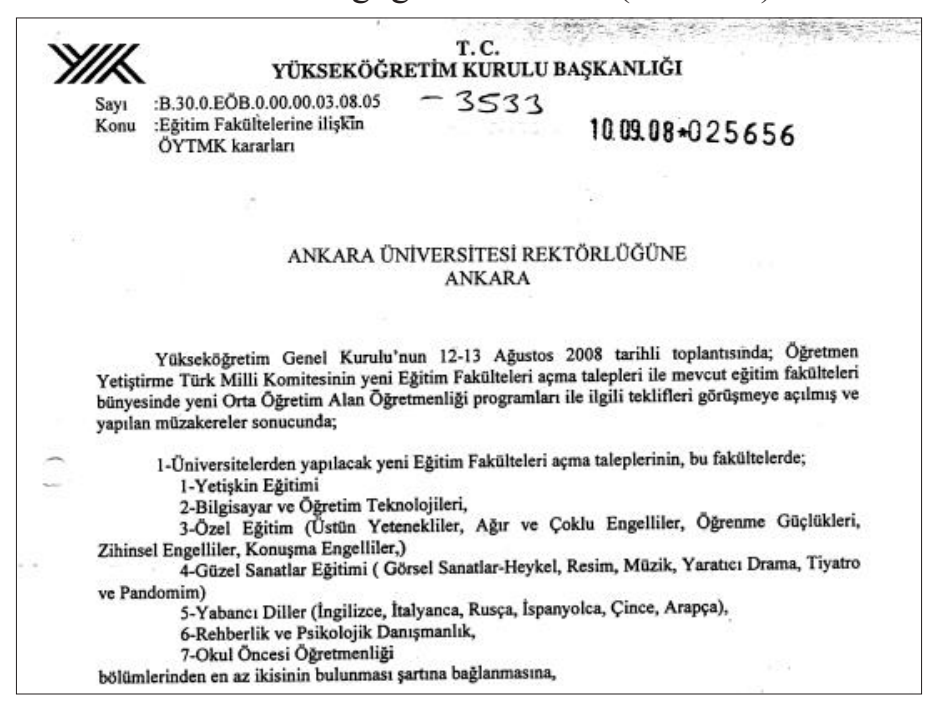

Görsel 8. Yükseköğretim Kurulu Başkanlı̆̆ ÖYTMK Kararına ilişkin Görüntü’de Yaratıcl Drama 'nın Güzel Sanatlar Ĕ̆itimi Alanı olduğu görülmektedir.

Bu verilerden yola çıkarak ile Talim Terbiye Kurulu'nca yayımlanan bazı belgelerde Milli Eğitim Bakanlığı'nın tüm belgelerinde ve Yükseköğretim Kurulu'nca alınan kararlarda drama alanının güzel sanatlar alanı veya sanat alanı olarak anıldığı görülmekteyken aynı alanın atama adına tanımlandığı üst başlığın "Eğlence Hizmetleri” olduğu görülmektedir. Dolayısıyla drama alanının atamaya esas alan olarak "Eğlence Hizmetleri” başlığı altında yer alması tutarsı bir görüntünün varlığını göstermektedir. 


\section{Drama Öğretmenliğine İlişkin Ölçütler}

Milli Eğitim Bakanlığı Talim Terbiye Kurulu Başkanlığı tarafından oluşturulan ve en son 20/02/2014 tarihli ve 9 sayılı Kurul Kararı, Mart 2014-2678 sayılı Tebliğler Dergisi'nde yer alan Öğretmenlik Alanları, Atama ve Ders Okutma Esasları başlıklı belge incelendiğinde, drama alanında öğretmenlik yapabilecek kişilerin aldıkları eğitime ilişkin iki temel unsur belirtildiği görülmektedir.

a) Belgede, Türkçe Öğretmenliği ile Türk Dili ve Edebiyatı Öğretmenliği Bölümlerinden mezun olanların drama dersini verebileceğine yönelik bir belirleme yapıldığg görülmektedir (Görsel 9).

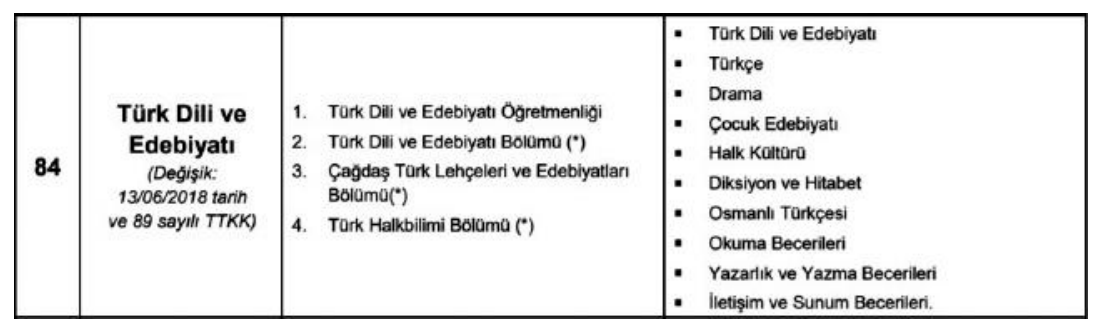

Görsel 9. Tebliğler Dergisi Mart 2014- Öğretmenlik Alanlarl, Atama ve Ders Okutma Esasları/Türk Dili ve Edebiyatı Atama Alanına İlişsin Çizelge Görüntüsü’nde Drama Dersinin Türk Dili ve Edebiyatı alanlarından mezun olan kişiler tarafindan ögretilebileceği belirtilmektedir.

Bu kapsamda 2018 yılında Yüksek Öğretim Kurulu'nca düzenlenen Eğitim Fakülteleri Türkçe ve Türk Dili Edebiyatı bölümlerine ilişkin eğitim programları ders içeriği gözden geçirilmiştir. Meslek bilgisi, genel kültür ve alan eğitimi kodlu dersler tarandığında Ĕgitimde Drama dersinin her iki bölümün öğretmen adayları için de Meslek Bilgisi Seçmeli Dersleri arasında olduğu görülmüştür. Ders içeriği, aşağıdaki tümcelerle ifade edilmiştir:

Drama ve yaratıcı dramanin temel kavramları (drama, yaratıcllı, yaratıcı drama, oyun ve tiyatro pedagojisi, iletişim-etkileşim, rol oynama, doğaçlama, eylem, dramatik oyun, çocuk tiyatrosu, kukla, pantomim vb.); yaratıcı dramanın aşamaları, boyutları ve öğeleri; rol oynama ve doğaçlama; yaratıcı dramanın tarihçesi; toplumsal olaylar ve yaratıcı drama ilişkisi; eğitimde dramanın uygulama basamakları; eğitimde dramada yararlanılabilecek kaynaklar; yaratıcı drama ders planının hazırlanması ve uygulanmasi; dramanın bireysel ve sosyal gelişime katklst.

Öncelikli olarak ifade edilen içerik için belirlenen ve öğrencinin iş yükünü yansıtan AKTS oranına bakıldığında Meslek Bilgisi Seçmeli Dersi olarak belirtilen eğitimde drama dersinin 2 AKTS olduğu görülmektedir. 1 AKTS'nin saat bazındaki karşıllğı Türkiye Yükseköğretim Yeterlilikleri Çerçevesi'nde 25 ilâ 30 saat olarak belirtilmiştir (Erişim tarihi 24 Mayıs 2019). Belirtilen içeriğin MEB Talim ve Terbiye Kurulu Başkanlığı tarafindan 18.11.2005 tarih ve 346 sayılı kararı ile onaylı sertifikalar bazındaki saat karşılığının 320 saat olduğu düşünüldüğünde bu ders içeriğinin en fazla 60 saat ile karşılanabileceğine ilişkin soru işaretleri ortaya çıkmaktadır.

$\mathrm{Bu}$ durumda, Türkçe ile Türk Dili ve Öğretmenliği bölümlerinde yaratıcı drama alanı ile ilişkilendirilebilecek bir diğer Meslek Bilgisi Seçmeli Dersi olan Tiyatro ve Canlandırma dersi verilebilir. Bu iki dersi seçmeli olarak alan öğrencinin toplamda 4 AKTS'lik, yani en fazla 120 saatlik bir eğitimle bu alandaki yeterliliğini geliştirebileceği düşünülmüştür. Ancak görülmektedir ki iki derse ayrılan öğrenci iş yükü, drama alanına yönelik sertifika programı için belirlenen iş yükünün 
yarısını bile oluşturmamaktadır. Ayrıca Tiyatro ve Canlandırma dersinin içeriği gözden geçirildiğinde şu ifadelerle karşılaşılmaktadır:

Tiyatro kavramı, Türk tiyatrosu ve bölümleri hakkında genel bilgiler; halk tiyatrosunun tanımı ve bölümlerinin (köy tiyatrosu, karagöz, meddah, ortaoyunu, kukla) tiyatronun tarihî gelişsim süreci içinde açılklanması; anlayışlar ve yönetmenlik uygulamaları, tiyatro teknikleri, sınıf içi tiyatro uygulamaları, tiyatro ve yaratıcı drama arasındaki ilişkiler, sahneleme teknikleri ve uygulamalart.

Türkçe ile Türk Dili ve Edebiyatı bölümleri adına tanımlanan bu iki ders, içerikleri bakımından birbirini destekler nitelikte olmakla birlikte, içerik ve kapsam yönüyle birbirinden farklı oldukları görülmektedir. Ayrıca bu iki dersin zorunlu dersler olmadığı, derslerin eğitim programında seçimlik dersler olarak yer aldıkları, bu dersleri almanın öğretmen adayının kendi inisiyatifinde olduğu unutulmamalıdır. Talim Terbiye Kurulu'nun belgesi temel alındığında bu derslere ilişkin donanımı sorgulanabilir olan Türkçe ile Türk Dili ve Edebiyatı öğretmenlerinin "doğalında drama öğretmeni”" olduklarına ilişkin bir algının varlığından söz edilebilir. Fakat bu algı ve bu algıdan doğan uygulama, bilimsel açıdan eksiklikler ve yanlışlıklar içermektedir.

b) Milli Eğitim Bakanlığg Talim Terbiye Kurulu Başkanlığı tarafından oluşturulan ve en son 22/02/2019 tarihli ve 4 sayılı Kurul Kararı, Mart 2019-2738 sayılı Tebliğler Dergisi'nde yer alan Öğretmenlik Alanları, Atama ve Ders Okutma Esasları başlıklı belgenin Bazı Derslerin Hangi Alan Öğretmenleri Tarafindan Okutulacağına İlişkin Açıklamalar başlığının ilk maddesi drama alanına ayrılmış ve şöyle ifade edilmiştir:

'Drama: Öncelikle üniversitelerin 'Drama', 'Oyunculuk', 'Drama ve Oyunculuk' bölümü mezunu olan öğretmenler olmak üzere, lisans ve lisansüstü sırasında drama dersi aldiğını belgelendirenler ile içeriği ve süreci bakanlıkça belirlenen eğitimleri tamamlayarak sertifika alan ögretmenler tarafindan okutulur.”

Orijinal belgede üç satır yer tutan bu ifade kendi içinde birçok farklı olasılığı barındırdığ 1 için üç alt madde ile ele alınmıştır.

b.1. Açıklamanın ilk vurgusu olan “... üniversitelerin 'Drama', 'Oyunculuk', 'Drama ve Oyunculuk' bölümü mezunu olan öğretmenler olmak üzere..." ifadesinin drama dersini verebilecek bölüm mezunlarına gönderme yaptığı görülmektedir. Bu durumda Türkiye'de bulunan "Drama", “Oyunculuk”, "Drama ve Oyunculuk” bölümlerinin kapsamına ilişkin de inceleme yapılmıştır.

Belirtilen gereklilik doğrultusunda 2018 ÖSYM Yükseköğretim Programları incelendiğinde öncelikli olarak, Türkiye üniversiteleri arasında "Drama" adı ile anılan bir bölüm olmadığ1 belirlenmiştir. "Drama ve Oyunculuk" bölümlerinin ise İstanbul Aydın Üniversitesi ile Girne Amerikan Üniversitesi olmak üzere iki özel üniversitede bulunduğu görülmektedir. Bu iki üniversitede bulunan Drama ve Oyunculuk Bölümü eğitim programları incelendiğinde drama, yaratıcı drama veya eğitimde drama derslerine yönelik herhangi bir zorunlu bir dersin bulunmadığı programda görülür.

“Oyunculuk” bölümünün ise Akdeniz, Beykent, Bülent Ecevit, Çukurova, Doğuş, Dokuz Eylül, Hacettepe, Kocaeli, Süleyman Demirel, Uludağ ve Yakın Doğu Üniversitelerinin ya Güzel Sanatlar Fakültelerinde ya da Konservatuarlarında yer almaktadır-ki bu bölümlerde de drama veya eğitimde drama dersi bulunmamaktadır veya çok azında seçimlik bir ders olarak yer almaktadır. 
Bu noktada program amacına bakıldığında, örneğin Girne Amerikan Üniversitesi Drama ve Oyunculuk Bölümü (24 Mayıs 2019)) kariyer olanakları şu şekilde ifade edilmiştir:

Drama ve Oyunculuk Bölümü, ilgilendiği çalışma alanlarının genişliği nedeniyle bir profesyonel oyuncuda olması fark yaratacak olan bazı özelliklerin kazandırllması ve bu programdan mezun olan oyunculara hem yurt içinde hem uluslararası ölçekte saygın bir kariyer yapabilme olanağının sağlanması için tasarlanmıştır. Klasik oyunculuk eğitimi yanı sıra, dans, müzik, şarkı söyleme gibi diğer disiplinlerin eğitimini de barındırdığından günümüz performans sanatı anlaylşı çerçevesinde artistik ve teknik bilgi açısından en üst seviyede performans sanatçılarl yetiştirmeyi hedefler. Bu bakımdan çoğu akademik oyunculuk eğitimi veren programlardan çok daha kapsamlı bir yapı oluşturmaktadır. Bu nedenle, mezunlarımız performans sanatı alaninda birçok farkl yerlerde istihdam edilebilirler ve dolaylsı ile bu programın mezunlarına talep, diğer oyunculuk programlarının mezunlarına göre çok daha yüksektir.

İfade incelendiğinde, programın amacının tiyatro sanatına yönelik oyuncu yetiştirmek olduğu; bölümün sonuç odaklı ve sanatsal kaygı güden bir bölüm olduğu görülmektedir. Ayrıca bölümde yaratıcı drama ya da eğitimde drama odaklı eğitime yönelik bir ifade de bulunmamaktadır. Bu nedenle bu bölümden mezun olanların drama derslerini verebilme durumu eğitsel açıdan önemli bir sorun oluşturmaktadır. Pedagojik açıdan da herhangi bir ders almayan bu bölüm mezunları hiçbir biçimde drama derslerini yürütemez.

Diğer yandan Hacettepe Üniversitesi Oyunculuk Bölümü eğitim programı (24 Mayıs 2019) incelendiğinde bölümde Yaratıcı Drama 1 ve Yaratıcı Drama 2 derslerinin seçimlik dersler olarak yer aldığı görülmektedir. Eğitim programında Yaratıcı Drama 1 dersinin içeriği "oyun ve tiyatro pedagojisinin temel yaklaşımı" olarak belirtilirken Yaratıcı Drama 2 dersinin içeriği "oyun ve tiyatro pedagojisi alanı ve işlevi” olarak tanımlanmıştır. Her biri 2 AKTS olan bu derslerin her ikisini alan Oyunculuk Bölümü mezunlarının ise tıpkı (a) maddesinde (Türkçe ile Türk Dili ve Edebiyatı Öğretmenliği Bölümü mezunlarına ilişkin olarak) belirtilen gerekçelerle aynı kaygılara sebep olduğu söylenebilir; Oyunculuk Bölümü mezunlarının drama ile ilgili aldıkları en fazla iki ders ile drama alanının donanımına sahip olabileceği düşünülemez. Üstelik bu durumun bölüm de farkında olmalı ki bölüm mezunlarının pedagojik formasyon almaları durumunda drama derslerini yürütebileceğine ilişkin bir ifadeye yer vermişlerdir. Bu hassasiyet göz ardı edilmeden yine de belirtilmelidir ki oyunculuk eğitimi sonrasında alınan pedagojik formasyonla drama öğretmenliği yetkinliğinin edinilmesi, öğretmen olma yetkinliğine ilişkin soru işaretleri doğurmaktadır. Sonuç olarak bu bölüm mezunları da programlarının bu haliyle drama derslerini yürütebilecek yeterliğe sahip değildir.

b.2. Açıklamanın ikinci vurgusunun "lisans ve lisansüstü sırasında drama dersi aldı̆̆ını belgelendirenler" ifadesi olduğu görülmektedir. Bu tümce ile lisans ya da lisansüstü eğitimi sırasında drama dersini alanların bu dersi verebileceği belirtilmektedir. Yukarıda (a) maddesinde ayrıntılı olarak belirtildiği üzere bu ifade, lisans ya da bazı lisansüstü programlarda seçimlik olarak drama dersi almış bir kişinin bu dersi doğrudan verebileceğine ilişkin anlayışın varlığına yönelik bir gösterge olarak yorumlanabilir. Öğrenim yaşamı boyunca seçimlik alınan bir ders ile drama dersinin yürütülebileceği anlayışından vazgeçilmelidir. Bu durum diğer dersler için de düşünülmelidir. Sözgelimi seçimlik olarak İngilizce, Almanca vd. dil derslerinin alınması veya herhangi bir dersin alınması, kişiye bu dersleri yürütme yetkisini vermeyeceğine göre bu durum drama dersi için de geçerli olmalıdır. 
b.3. Talim Terbiye Kurulu'nun drama dersine yönelik açıklamasının son vurgusunun “... içeriği ve süreci bakanlıkça belirlenen eğitimleri tamamlayarak sertifika alan öğretmenler tarafindan okutulur..." olduğu görülmektedir.

$\mathrm{Bu}$ vurgu, Talim Terbiye Kurulu'nun drama dersini verebilecek öğretmenlerin betimlenmesindeki tek doğru vurgudur. Konu ile ilgili Türkiye'de herhangi bir lisans programının olmaması, çift dal veya yan dal programının da uygulanmaması nedeniyle bu vurgu, yasal ve bilimsel açıdan tek doğru vurgu olarak değerlendirilmektedir.

Türkiye'de drama öğretimi (ne yazık ki böyle bir öğretmenlik tanımı henüz söz konusu değildir) Ankara Üniversitesi ve Anadolu Üniversitesi'nde verilen eğitimde drama/yaratıcı drama yüksek lisans eğitimi mezunları ile Milli Eğitim Bakanlığı'na bağlı özel kurslar statüsünde 320 saatlik sertifika programını tamamlayan eğitmenler tarafından yürütülmektedir. Pek çok okulda bu eğitmenler ya usta öğretici olarak ya da herhangi bir dal öğretmeni olup drama öğretmeni olarak istihdam edilmektedir.

Belirtmek gerekir ki drama eğitimi veren lisansüstü programlar ya da MEB onaylı kurslar öğretmen yetiştirmemektedir. Bu programları tamamlayarak sertifika almaya hak kazanan öğretmenler ya da farklı alanlarda çalışanlar bu dersleri yürütebilmektedir. Dolayısıyla ifadenin yanlış olmamakla birlikte yeterince açık olmadığı söylenebilir.

\section{Tartışma, Sonuç ve Öneriler}

Belgelerin incelenmesiyle ortaya konan veriler doğrultusunda öncelikli olarak, dramanın Atamaya Esas Olan Alan belgesinde Eğlence Hizmetleri altında ele alınmaması gerektiği söylenebilir. $\mathrm{Bu}$ ifade, gerek Talim Terbiye Kurulu'nca düzenlenen belgeler arasındaki tutarlılığın sağlanması, gerekse alanın bilimsel olarak doğru tanınması/tanıtılması için değiştirilmelidir. Milli Eğitim Bakanlığı'nca düzenlenmiş eğitim programlarında belirtildiği üzere dramanın bir sanat eğitimi alanı olduğu ifade edilmelidir. Drama; resim, sanat tarihi, müzik gibi yeni bir öğretmenlik alanı olarak ilan edilmeli; yine bu dersler gibi güzel sanatlar alanı altında yer almalıdır. San'ın da ifade ettiği gibi yaratıcı drama bir sanat eğitimi alanıdır (Başbuğ, 2006).

Araştırmada ele alınan ikinci ana başlık, drama öğretmenlik kriterlerine ilişkin unsurlardır. Belge incelendiğinde drama dersini verebilecek olan kişiler şu şekilde sıralanmaktadır: Türkçe ile Türk Dili ve Edebiyatı öğretmenleri; Drama, Oyunculuk, Drama ve Oyunculuk Bölümlerinden mezun olan öğretmenler; lisans veya lisansüstü eğitimi sırasında drama dersi aldığını belgelendiren kişiler; içeriği ve süreci bakanlıkça belirlenen eğitimleri tamamlayarak sertifika alan öğretmenler.

Bu tanımlamaya göre drama dersini verebilecek olan kişilere bakıldığında Türkçe ile Türk Dili ve Edebiyatı öğretmenlerinin ve Oyunculuk ile Drama ve Oyunculuk Bölümü mezunlarının drama dersi verebilecek donanıma sahip olduğu gibi yanlış bir algı olduğu söylenebilir. MEB Öğretmenlik Mesleği Genel Yeterlikleri (2017) gözden geçirildiğinde, öğretmenlik mesleğinin yeterliklerinden biri olan alan bilgisinin iki alt başlığının alanla ilgili kuramsal bilgi ile pedagojik alan bilgisi olduğu görülmektedir. Belirtilen bölümlerdeki öğrencilerin eğitim programlarında drama alanına ilişkin kuramsal bilgi ile pedagojik donanımının bir arada işlenmediği görülmektedir.

Türkçe öğretmenlerinin drama dersine ilişkin görüşlerinin (Kesici, 2014), drama yöntemini kullanma durumlarının (Maden, 2011) ve uygulama yeterliliklerinin (Tutuman, 2011) araştırıldığ1 
çalışmalar da göstermektedir ki Türkçe öğretmenleri drama dersi süresinde kendi ders içeriklerini yetiştirmeye çalışmakta; öğretmenlerin büyük çoğunluğu dramayı tiyatro sanmakta; drama alanı ile kendisi ilgilenmediği sürece yetersizkalmaktadırlar(Burgul Adıgüzel, 2018). Yapılan bu araştırmaların yanı sıra farklı branşlardan öğretmen adaylarıyla yapılan deneysel bir çalışmada (Oğuz Namdar ve Kaya, 2018) öğretmen adayları ile yapılan uygulamaya dönük drama dersleri sonrasında öğretmen adaylarının yaratıcı drama yöntemini kullanmaya yönelik öz yeterlik puanlarında anlamlı bir artış olduğu belirtilmiştir. Bu durumda öğretmenlik bölümlerindeki drama derslerinin işleniş biçimine yönelik farklı1ıkların ele alınması gerektiği ortaya çıkmaktadır. Bu durum, yaratıcı drama derslerini öğretmen adayları ile anlamlı bir şekilde yürütebilecek olan yaratıcı drama alanında uzmanlaşmış öğretim elemanı sayısına ilişkin destekleyici bir tablonun olmaması şeklinde yorumlanabilir.

Öğretmenlik programlarına ilişkin tablonun yanı sıra Türkiye'de bulunan "Drama ve Oyunculuk" ve "Oyunculuk" eğitimlerine ilişkin durum şu şekilde yorumlanabilir: İçerisinde drama kuramsal bilgisi bulunsa bile bu programlar, eğitimde dramayı amaçlamamakta, bu bölümlerde dramanın eğitimde kullanımına ilişkin bir kaygı taşınmamaktadır. Dolayısıyla oyuncu olan kişilerin bu sorumluluğu taşımasının beklenmesi, çocuklara olan saygı temelinde ve çocuklarda davranış değişikliği yaratmayı amaç edinen resmi eğitim sistemi adına uygun görülemez. Somers'ın da ifade ettiği gibi yaratıcı drama sanatsal boyut taşımakla birlikte pedagojik yönü olan bilimsel bir alandır (Adıgüzel, 2007). Benzer bir görüşle San da (2008) tiyatro ve yaratıcı dramanın ayrımlarını pedagojiyi düşünerek ortaya koymuştur.

Belgede dikkat çeken bir diğer nokta Drama ve Oyunculuk veya Oyunculuk mezunları ile Milli Eğitim Bakanlığı'nca belirlenen eğitimleri tamamlayan kişilerin “öğretmenler” olarak anılmasıdır. Halbuki öğretmen, Milli Eğitim Bakanlığ 1 tarafından "yükseköğretim kurumlarında genel kültür, özel alan ve pedagojik formasyon eğitimi alarak yetişmiş olan kişi”" olarak tanımlanmaktadır. Ayrıca Drama ve Oyunculuk veya Oyunculuk Bölümü mezunlarının statüsü “oyuncu” iken, sertifika eğitimini tamamlayan kişilerin statüsü "usta öğretici” veya "eğitmen” olarak belirlenmiştir. Dolayısıyla Drama ve Oyunculuk veya Oyunculuk Bölümlerinden mezun olan kişiler ile sertifika eğitimini tamamlayan kişilerin öğretmen olduğuna yönelik ifade doğru bir bilgiyi yansıtmamaktadır.

Belgede ele alınan, "lisans veya lisansüstü eğitimi sırasında drama dersi aldığını belgelendiren kişilerin drama öğretmeni olabilecek yeterlilikte” görülmesine ilişkin belirleme yanlıştır. Bir önceki kısımda da söz edildiği gibi en fazla 4 AKTS ile bir alana ilişkin yetkinliğin ortaya konması, Türkiye Yükseköğretim Yeterlilikler Çerçevesi'nde (24 Mayıs 2019) belirtilen alt sınırın lisans eğitim düzeyi için 240 AKTS olduğu düşünülürse kabul edilebilir görünmemektedir. Ayrıca -akla gelen ilk örnekleher üniversite lisans öğrencisinin alması zorunlu olan derslerin Atatürk İlke ve İnkılapları, Türkçe ve yabancı dil olduğu bilinmektedir (ÖSYM, 24 Mayıs 2019). Benzer bir mantıkla bakılacak olursa tüm lisans mezunlarının Atatürk İlke ve İnkılapları, Türkçe ve yabancı dil derslerini aldıkları için her bir alanda ders verebilecek yetkinlikte sayılmaları gerekir. Fakat her biri kendine özgü içerik ve tartışmalara sahip olan bu alanların kendi uzmanlarını yetiştirdiği bilinmektedir. Dolayısıyla bir uzmanlık alanı olan drama için de diğer alanlarda olduğu gibi dramaya özgü bütüncül bir programın eğitimini almış kişilerin bu eğitimi vermesi daha uygundur. Dolayısıyla Aykaç ve Ulubey'in (2008) 2005 eğitim programında yaratıcı drama dersine ilişkin yaptıkları çalışma sonucundaki önerilerinden birinin ilgili makamlarca değerlendirilmesinin yararlı olacağı söylenebilir: "Eğitim fakültelerinde yaratıcı drama öğretmenliği adı altında bir bölüm açılarak bu alanla ilgili öğretmen yetiştirilmeli ve bu öğretmenler eğitim kademelerinde ilk ve orta öğretim kurumlarında görevlendirilmelidir.” 
Son olarak belirtmek gerekir ki Türkiye'de yaratıcı drama, eğitimde drama ya da drama içerikli dersler Eğitim Fakülteleri bünyesinde başlamış, gelişmiş ve yine Eğitim Bilimleri Fakülteleri bünyesinde sürdürülmektedir; Ankara Üniversitesi ve Anadolu Üniversitesi'ne bağl1 Eğitim Enstitülerinde yaratıcı drama ya da eğitimde drama adları ile bu alanda lisansüstü eğitim verilmektedir. Dolayısıyla yaratıcı drama alanında eğitmenlik yapacak olan kişilerin belirtilen lisansüstü öğrenimini tamamlayanlar ile MEB onaylı 320 saatlik bir sertifika programında usta öğretici olarak eğitim almış kişiler olabileceği söylenebilir. Ayrıca Mesleki Yeterlik Kurumu Ulusal Meslek Standardı çerçevesinde 6. Seviyede kabul edilen Yaratıcı Drama Eğitmeni standardı 18UMS0674-6 referans kodu ile Resmi Gazete'nin 09.06.2018-30446 tarih ve sayı ile yayınlanmıştır. Bu standartta belirtilen yeterlik 325 saat 13 kredi olarak belirlenmiştir. Bu nedenle MEB onaylı programların da saatlerini 325 saat olarak güncellemeleri önemlidir.

Tüm bu açıklamalara dayalı olarak ve Milli Eğitimin Temel İlkeleri’nden biri olan bilimsellik ilkesinin yerine getirilmesi adına Talim Terbiye Kurulu Öğretmenlik Alanları, Atama ve Ders Verme Esasları açıklamalarına yönelik öneriler şu şekilde sıralanabilir:

- Eğlence hizmetlerinin drama vb. alan mezunları tarafından verilmesi anlayışından vazgeçilmelidir çünkü drama bir eğlence hizmeti değildir.

- Drama, resim, sanat tarihi, müzik gibi yeni bir öğretmenlik alanı olarak ilan edilmeli ve drama dersi yine bu dersler gibi güzel sanatlar alanında yer almalıdır.

- Drama dersinin yalnızca Türkçe ve Türk Dili ve Edebiyatı Eğitimi Bölümü mezunları tarafından doğrudan verilebileceği açıklamasından vazgeçilmelidir.

- Lisans ve lisansüstü öğrenim süresince "bu dersi alanlar ve bu dersi aldığını belgelendirenler" ifadesi kaldırılmalıdır.

- Milli Eğitim Bakanlığg ve Talim Terbiye Kurulu, YÖK nezdinde drama öğretmenlerinin lisans ya da yan alan olarak yetişebilmesi için Eğitim Fakültesi veya Eğitim Bilimleri Fakültesi’nde yer alan Güzel Sanatlar Eğitimi Bölümlerinde, Drama Eğitimi ya da Eğitimde Drama Anabilim Dalının açılmasına yönelik girişimde bulunmalıdır. Görsel Sanatlar Öğretmenliği, Resim-İş Öğretmenliği, Müzik Öğretmenliği vb. ortak alanlarda olduğu gibi "Drama Öğretmenliği” alanı da bir ortak alan dersini yürütecek alan olarak açılmalı, tüm öğretmenlik alanlarına yönelik bir "yan dal” programı olarak uygulanmalıdır.

- Mesleki Yeterlik Kurumu'nun yayınladığı Yaratıcı Drama Eğitmenliği standardı göz önünde bulundurulacak 325 saat 13 kredi olarak biçimde özel kurslar programları güncellenmelidir.

- Talim Terbiye Kurulu, Öğretmenlik Alanları, Atama ve Ders Okutma Esasları belgesinde Drama Dersine yönelik açıklama aşağıda belirtildiği biçimde düzeltilmelidir:

Drama: Üniversitelerin güzel sanatlar eğitimi bölümü eğitimde drama/yaratıcı drama öğretmenlik alanları mezunları, eğitimde drama/yaratıcı drama yan dal mezunları ile yaratıcı drama ya da eğitimde drama anabilim dalları ya da programlarında yüksek lisans yapmış ya da içeriği ve süreci bakanlıkça belirlenen eğitimleri tamamlayarak en az 325 saatlik Yaratıcı Drama Eğitmenliği sertifikası alan öğretmenler tarafından okutulur. 


\section{Kaynakça}

Adıgüzel, H. Ö. (2007). David Davis ve John Somers ile İngiltere ve Türkiye`deki drama eğitiminin karşılaştırılması. Yaratıcı Drama Dergisi, 1(3/4), 213-220.

Adıgüzel, H. Ö. (2008). Türkiye'de eğitimde yaratıcı dramanın yakın tarihi. Yaratıcı Drama Dergisi, 1(5), 9-49.

Adıgüzel, Ö. (2019). Eğitimde Yaratıcı Drama (3. Baskı). İstanbul: Yapı Kredi Yayınları.

Aykaç, N. \& Ulubey, Ö. (2008). Yaratıcı drama yöntemi ile yapılandırmacılık ilişkisinin 2005 MEB ilköğretim programlarında değerlendirilmesi. Yaratıcı Drama Dergisi, 1(3/4), 213-220.

Başbuğ, S. (2006). Yaratıcı dramanın Türkiye'deki öncülerinden "Prof. Dr. İnci San'ın yaratıcı drama anlayışı”. Yaratıcı Drama Dergisi, 3(6), 25-44.

Bowell, P., \& Heap, B. S. (2013). Planning process drama- enriching teaching and learning (2nd ed.). Routledge.

Burgul Adıgüzel, F. (2018). Türk dili ve edebiyatı öğretmenlerinin yaratıcı drama yöntemine ilişkin farkındalıkları ve yaratıcı drama yöntemini derslerinde kullanma durumları.Gıyasaettin Aytaş \& Aliye Uslu Üstten (Ed.), Prof. Dr. Alemdar Yalçın Armağanı Cilt:2 içinde (s. 242-273). Ankara: Sonçağ Matbaacılık

Girne Amerikan Üniversitesi Drama ve Oyunculuk Bölümü Kariyer Olanakları (b.t). Erişim tarihi 23 Mayıs 2019, Erişim adresi Girne Amerikan Üniversitesi web sitesi https://aday.gau.edu.tr/?page=program\&id=55

Hacettepe Üniversitesi Oyunculuk Programı Ders Listesi (b.t.). Erişim tarihi 23 Mayıs 2019, Erişim adresi Hacettepe Üniversitesi web sitesi http://akts.hacettepe.edu.tr/ders_listesi.php?prg_ref=410c$62643 \mathrm{c} 30$ ecc3013c38aab23f314 \& birim_kod=481\&submenuheader=2\&prg_kod=481

Karasar, N. (2015). Bilimsel araştırma yöntemi. Ankara: Nobel Yayınları.

Kesici, A. E. (2014). Drama dersine ilişkin öğretmen görüşleri. Abant İzzet Baysal Üniversitesi Eğitim Fakültesi Dergisi, 14(2), 186-203.

Maden, S. (2011). Türkçe öğretiminde drama yönteminin kullanımı ile ilgili sorunlar. Adıyaman Üniversitesi Sosyal Bilimler Enstitüsü Dergisi, (6), 107-122.

Merriam, S. B. (2013). Nitel araştırma: Desen ve uygulama için bir rehber (3. Baskıdan Çeviri, Çeviri Editörü: S. Turan). Ankara: Nobel Yayın Dağıtım

Oğuz Namdar, A., \& Kaya, Ö. S. (2018). Öğretmenlerin yaratıcı drama yöntemini kullanmaya yönelik özyeterlik algıları ve tutumları. Hacettepe Üniversitesi Ĕ̈itim Fakültesi Dergisi. Advance online publication. doi: 10.16986/HUJE.2018044110

Öğretmen Yetiştirme ve Geliştirme Genel Müdürlüğü (2017). Öğretmenlik mesleği genel yeterlikleri. Erişim adresi https://oygm.meb.gov.tr/www/ogretmenlik-meslegi-genel-yeterlikleri/icerik/39

Patton, M.Q. (2014). Nitel araştırma ve değerlendirme yöntemleri. 3. Baskıdan Çeviri. Bütün, M \& Demir, S. B. (Edt.), Ankara: Pegem Akademi.

San, İ. (2008). Adlandırmayı değiştirmeyelim. Yaratıcı Drama Dergisi, 1(5), 103-113.

Somers, J. (2012). Drama in schools making the educational and artistic argument for its inclusion, retention and development (N. Govas, M. Katsaridou, D. Mavreas, Ed.) Theatre \& Eduaction bonds of solidarity içinde (ss. 110-118). Athens

Talim Terbiye Kurulu Başkanlığı (b.t.). Sosyal Etkinlikler Dersi Kapsamında Yer Alan Faaliyetler. Erişim adresi http://mufredat.meb.gov.tr/Programlar.aspx

Talim Terbiye Kurulu Başkanlığı (18 Kasım 2018). Yaratıcı Drama Eğitmenliği/Liderliği Kurs Programı. Erişim adresi https://ookgm.meb.gov.tr/meb_iys_dosyalar/2014_02/14111717_346.pdf

Talim Terbiye Kurulu Başkanlığı (12 Eylül 2018). Sosyal Etkinlikler Dersi Kapsamında Yer Alan Faaliyetler. Erişim adresi http://tebligler.meb.gov.tr/index.php/tuem sayilar/viewcategory/86-2018 
Talim Terbiye Kurulu Başkanlığı (21 Şubat 2018). Ortä̈ğretim Kurumları Haftalık Ders Çizelgeleri 2018. Erişim adresi http://ttkb.meb.gov.tr/www/haftalik-ders-cizelgeleri/kategori/7

Talim Terbiye Kurulu Başkanlığı (22 Şubat 2019). Öğretmenlik Alanları, Atama ve Ders Okutma Esasları. Erişim adresi https://ttkb.meb.gov.tr/www/ogretmenlik-alanlari/icerik/201

Tutuman, O. Y. (2011). Türkçe Öğretmenlerinin Yaratıcı Drama Uygulama Yeterlilikleri, (Yayımlanmamış yüksek lisans tezi). Dokuz Eylül Üniversitesi Eğitim Bilimleri Enstitüsü, İzmir.

Türkiye Yükseköğretim Yeterlilikler Çerçevesi (b.t.). Erişim tarihi 24 Mayıs 2019, Erişim adresi Yükseköğretim Kurulu web sitesi, https://www.yok.gov.tr/kurumsal/idari-birimler/egitim ogretim-dairesi/yeni-ogretmen-yetistirme-lisans-programlari

Yükseköğretim Kurulu (30 Mayıs 2018). Yeni Öğretmen Yetişstirme Lisans Programlart-Türk Dili ve Edebiyatı Öğretmenliği Lisans Programı. Erişim adresi https://www.yok.gov.tr/kurumsal/idari-birimler/egitim-ogretim-dairesi/yeni-ogretmen yetistirme-lisans-programlari

Yükseköğretim Kurulu (30 Mayıs 2018). Yeni Öğretmen Yetişstirme Lisans Programlart-Türkçe Öğretmenliği Lisans Programı. Erişim adresi https://www.yok.gov.tr/kurumsal/idari birimler/egitim-ogretim-dairesi/yeni-ogretmen-yetistirme-lisans-programlari

Yükseköğretim Kurulu (10 Eylül 2008). Eğitim Fakültelerine İlişkin ÖYTMK kararları.

Yüksekögretim Programları ve Kontenjanları Kılavuzu-2018 (b.t.). Erişim tarihi 24 Mayıs 2019, Erişim adresi Ölçme, Seçme ve Yerleştirme Başkanlığı web sitesi,https://www.osym.gov.tr/TR,15240/2018-yuksekogretim-programlari-ve kontenjanlari-kilavuzu.html

Zorunlu Dersler ve Öğretim Süresi (b.t.). Erişim tarihi 24 Mayıs 2019, Erişim adresi Ölçme, Seçme ve Yerleştirme Başkanlığ 1 web sitesi, http://www.osym.gov.tr/TR,1374/zorunlu-dersler-ve ogretim-suresi.html 


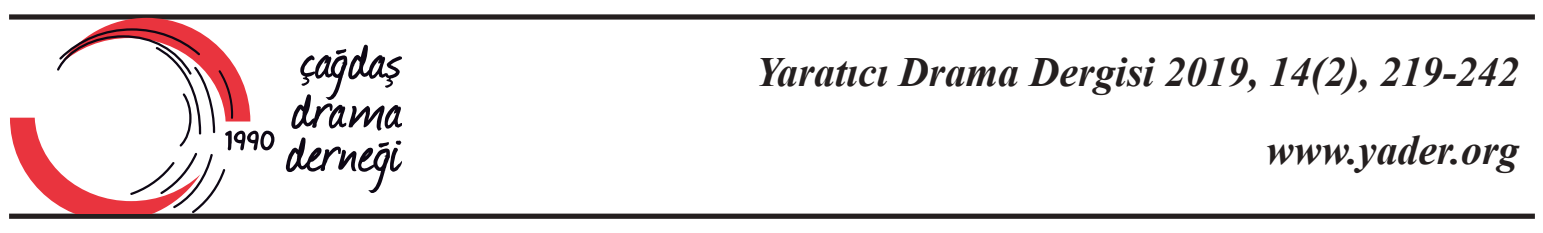

\section{Sınıf Öğretmenliği Adaylarının Yaratıcı Drama Oturumu Planlama Sürecinde Yaşadıkları Sorunların İncelenmesi*}

İhsan Metinnam ${ }^{1}$

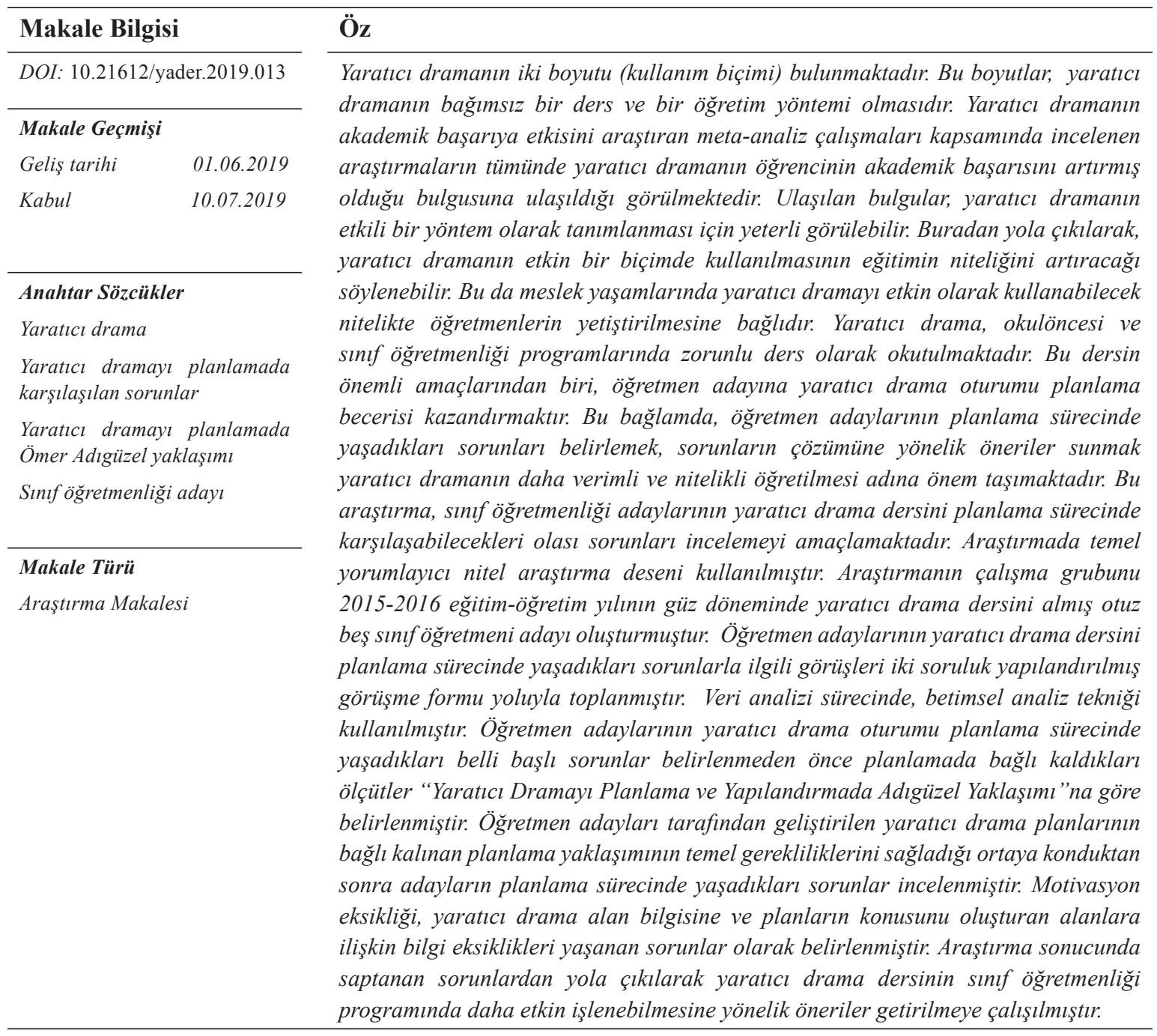

* $\quad$ Bu makale, 20-23 Nisan 2017 tarihleri arasında düzenlenmiş 26. Uluslararası Eğitim Bilimleri Kongresi’nde sunulmuş olan "Sınıf Öğretmeni Adaylarının Yaratıcı Drama Oturumu Planlama Süreçlerinde Karşılaștıkları Sorunların İncelenmesi” başlıklı sözlü bildiriden geliştirilerek oluşturulmuştur.

1 Dr., Ankara Üniversitesi Güzel Sanatlar Fakültesi, Ankara, Türkiye. E-posta: ihsanmetinnam@gmail.com. Orcid ID: https://orcid.org/0000-0001-6984-2693 


\section{Investigation of the Problems of Primary School Teacher Candidates in the Planning Process of Creative Drama Session**}

\begin{tabular}{lr}
\hline Article Info \\
\hline DOI: $10.21612 /$ yader.2019.013 \\
\hline Article History & \\
Received & 01.06 .2019 \\
Accepted & 10.07 .2019 \\
&
\end{tabular}

Keywords

Creative drama

Problems in planning creative drama

Ömer Adigüzelss approach to planning creative drama

Primary school teacher candidate

\section{Article Type}

Research paper

\begin{abstract}
Creative drama has two dimensions (usage forms). These dimensions are that creative drama is an independent lesson and a teaching method. In all of the meta-analysis studies investigating the effect of creative drama on academic achievement, it was seen that creative drama increased the academic achievement of students. The findings can be considered sufficient to define creative drama as an effective method. From this point of view, it can be said that the effective use of creative drama will increase the quality of education. This depends on the training of teachers who can use creative drama effectively in their professional lives. Creative drama is taught as a compulsory course in the primary school teacher program as well as preschool teacher programs. One of the main objectives of this course is to provide the student with the ability of planning creative drama sessions. In this context, it is important to identify the problems that teacher candidates have experienced during the planning process and to offer suggestions for the solution of the problems in order to teach creative drama more efficiently. This research aims to examine the potential problems that teacher candidates may encounter during the planning process of creative drama lesson. In the study, basic interpretive qualitative research design was used. The study group of the research consisted of thirty-five teacher candidates who took creative drama course in the fall semester of 2015-2016 academic year. Teacher candidates'opinions about the problems they experienced during the planning process of creative drama course were collected through a structured interview form with two questions. In the data analysis process, descriptive analysis technique was used. Before determining the major problems experienced by the teacher candidates during the creative drama session planning process, the criteria that they adhered to in planning were determined according to "Adigüzel Approach in Planning and Structuring Creative Drama". After it was revealed that creative drama plans developed by teacher candidates provided the basic requirements of the planning approach, the problems experienced by teacher candidates in the planning process were examined. Lack of motivation, lack of knowledge of creative drama and knowledge of the subject areas of the plans were identified as problems. Based on the problems identified as a result of the research, suggestions were made to make creative drama lesson more efficiently.
\end{abstract}

** This paper was developed from the oral-presentation titled as "Examining the Problems of Primary School Teacher Candidates in the Planning Process of Creative Drama Session" and was presented at the 26th International Congress of Educational Sciences between April 20-23, 2017. 


\section{Giriş}

Yaratıcı dramanın iki boyutu (kullanım biçimi) bulunmaktadır. Bu boyutlar, disiplin olarak yaratıcı drama ve yöntem olarak yaratıcı dramadır. Farklı kaynaklarda yaratıcı dramanın boyutlarının ders-yöntem, amaç-araç olarak yaratıcı drama biçiminde de geçtiği bilinmektedir. Disiplin olarak yaratıcı drama; matematik, fizik, Türkçe derslerinde olduğu gibi yaratıcı dramanın kendi alan bilgisinin ele alındığı süreçler olarak tanımlanabilir. Yöntem boyutu ise şu şekilde tanımlanabilir: "Yaratıcı drama sahip olduğu teknikleri işte koşarak drama alanının kendi konuları dışındaki konuları ögretmede kullanılır. Bu konular amaçları uygun olan her ders ya da her eğitim konusu için geçerli bir durumdur. Bu yöntemde işlenecek bir konunun dramatik bir çatışma içerisinde canlandırmalarla bizzat yaşatılarak öğretilmesi söz konusudur” (Adıgüzel, 2018).

Yaratıcı drama, iki boyuta ayrılmış gibi gözükse de yaratıcı dramanın hem ders boyutu hem yöntem boyutu bütün uygulamalarda işe koşulur. Yaratıcı drama alanında gerçekleştirilmiş çalışmaların bazılarında yöntem boyutuyla alan bilgisinin ayrı tutulduğu bir anlayışın göze çarptığı söylenebilir. Bu çalışmalar, temel kavramlara, tekniklere, yaratıcı dramanın alan bilgisine ilişkin basit hatalarla doludur. Sözgelimi, yapılan bilimsel çalışmaların çoğunluğunda yaratıcı drama halen bir teknik olarak ele alınmaktadır. Oysa yaratıcı drama, rol oynama, doğaçlama, donuk imge gibi kendine özgü tekniklere sahip bir disiplin ve yöntemdir. Bir diğer sık yapılan hata ise tekniklerin adlandırılmasında yaşanmaktadır. Sözgelimi, canlandırma ya da oyun birer teknik olarak plan künyesine yazılabilmektedir. Oysa canlandırma, yaratıcı dramanın içerisinde mutlaka yer alması gereken bir eylem olduğu gibi aynı zamanda planlama aşamalarından biridir. Bir diğer hata ise yaratıcı dramanın yöntem olarak kullanıldığı çalışmalarda ortaya çıkmaktadır. Belirlenen konu ile ilgili yapılandırılan yaratıcı drama oturumlarının birçoğunda didaktik ve mekanik bir şablonculuk göze çarpmaktadır. Sözgelimi, geri dönüşüm konusunun yaratıcı dramayla öğretildiği bir sürecin ısınma hazırlık aşamasında karton bardaklarla bir ritim çalışması yaptırıldıktan sonra canlandırma aşamasında dramatik yapısı sağlam olmayan doğaçlamadan çok küçük rol oyunları olarak tanımlanabilecek etkinliklerle devam edilmektedir. Oysaki bir yaratıcı drama oturumu planlanırken odaktaki baştan sonra dramatik bir kurgu içerisinde ele alınmalıdır. Katılımcılar daha sürecin en başından kurguya girmelidir. Böylece tıpk1 iyi bir roman okunurken kurgunun içerisine girilmesi gibi katılımcılar da inanarak yapılandırılan sürecin içine girerler. Katılımcı rolüne inandıktan sonra daha fazla sorumluluk almaya gönüllü olur. Böylece rol ve kurgu içerisinde tüm süreci derinlemesine sorgulamaya hazır bir hale gelebilir. Bu duruma, "inançsızlı̆̆ın geçici ve bilinçli olarak askıya alınması" denir. Yaratıcı drama süreçleri -mış gibi yapmaya yani kurgusallığa dayalıdır. Kurgu, kendi içerisinde tutarlı bir kurmaca gerçekliğe dönüşmedikçe, katılımcıların -mış gibi olana yani gerçek olmayan ilişkin inançsızlık durumları devam edecektir. Bunu engellemek için yaratıcı dramanın eğitsel ve estetik boyutu eş zamanlı yapılandırılmalıdır.

$\mathrm{Bu}$ hataların çoğunluğunun yaratıcı dramanın iki boyutunu birbirinden çok ayrı şeylermiş gibi düşünmekten kaynaklandığı ifade edilebilir. Oysa yaratıcı dramanın yöntem ve alan bilgisi, eğitsel ve estetik süreçleri birbirine sıkı sıkıya bağlı iki sarmal gibidir.

Yaratıcı dramayı yöntem olarak kullanmak isteyen bir öğretmen öncelikle kendisini yaratıcı drama alanında yetiştirmelidir. Bunun yanında, yaratıcı dramanın yöntem olarak kullanılmasının alan bilgisinden ayrı düşünülmemesi gerektiğinin farkında olmalıdır. Alan bilgisinden yoksun bir yaratıcı drama uygulaması teknik bir şablonculuğa indirgenmiş basit bir oyun ya da taklit etkinliğine 
dönüşebilir. Bowell ve Heep'in (2001, s.5) “Drama Öğrenim Sarmalı”nda da yaratıcı dramanın² ders ve yöntem boyutunun ayrılmaz bir bütün olduğu gösterilmektedir:

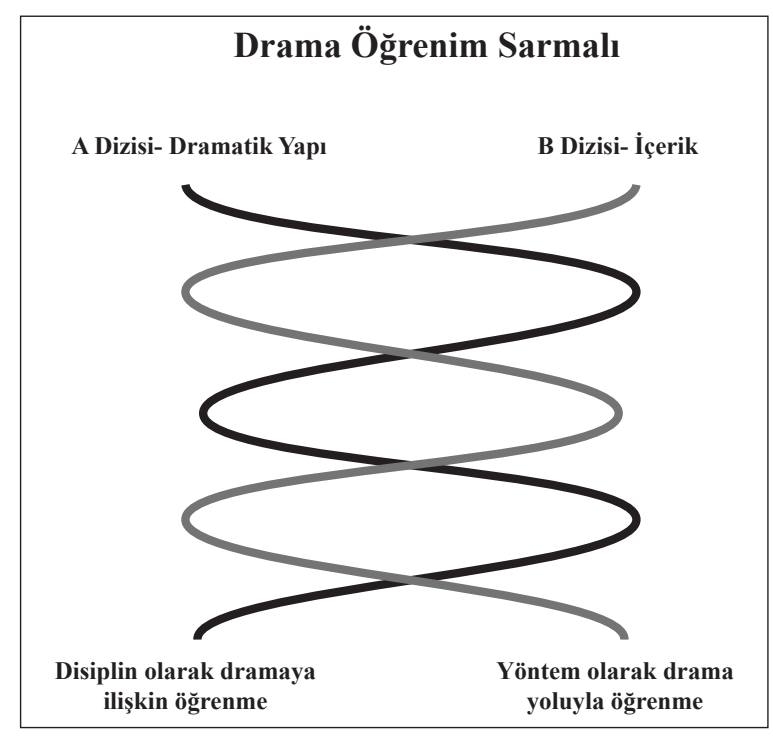

Şekil 1. Bowell ve Heep'in "Drama Öğrenim Sarmalı"

Bowell ve Heep'e (2001, s. 4) göre; "Ĕğer amaç yaratıcı dramanın alan bilgisiyle ilgili becerileri arttırmaktaysa 'A Dizisi'daha ön plana çıkacaktır. Ancak, eş zamanlı olarak 'B Dizisi'nin de işe koşulması gerekmektedir. Çünkü yapılan çalışma mutlaka bir 'içeriğe'sahip olmak zorundadır. Aynı biçimde eğer, yaratıcı drama yoluyla başka bir içerik öğretiliyorsa, 'B Dizisi' daha ön plana çıkacaktır. Ancak, 'A Dizisi'nin sürece eklemlenmesi gerekir ki yapılan şey yaratıcı drama olsun. Çünkü içeriği aktarmak için yaratıcı drama tekniklerine, dramatik yapı içerisinde sunulmuş canlandırmalara gereksinim bulunmaktadır". Yaratıcı dramanın kendi konusu dışındaki konular öğretilirken de konunun dramatik bir çatışma yani dramatik bir yapı içerisinde, yaratıcı dramanın tekniklerini işe koşarak canlandırmalarla öğretilmesi söz konusudur.

Kısacası yaratıcı dramayı yöntem olarak kullanmak isteyen bir öğretmenin hem kendi öğretmenlik alanının bilgisine hem de yaratıcı dramanın alan bilgisine hakim olması gerekmektedir.

Adıgüzel'e (2018) göre lider/öğretmen/eğitmenin sahip olması gereken özellikler şu şekildedir: "Yaratıcı drama alanında süreci tasarlayan, biçimlendiren, yöneten lider/eğitmenöğretmen kavramından; yaratıcı drama süreçlerine hakim, kuramsal ve uygulamalı çalışmalarda yeterli, uygulama becerisi de olan ya da aynı süreçleri bilip, farklı bir alanda uzman olan, yaratıcı dramayı bir yöntem olarak kendi alanında kullanan ögretmen anlaşılmalıdır." Mesleki Yeterlik Kurumu, Resmi Gazete'de 09.06.2018-30446 tarih ve sayı ile çıkan karar ve 18UMS0674-6 referans kodu ile yaratıcı drama eğitmenliğini “6.Seviye Yaratıcı Drama Eğitmeni” başlığıyla bir meslek dalı olarak tanımlamıştır. Bu kararın ardından, yaratıcı drama eğitmenliği ilgili belirlenen ölçütlerden (Mesleki Yeterlilik Kurumu, 2018) de yola çıkılarak bir yaratıcı drama eğitmeninin sahip olması gereken yeterlik ve tutumları kazanmak için yapması gerekenler aşağıdaki başlıklarda özetlenebilir:

2 Ulusal ve uluslararası alanyazında; "drama, eğitimde drama, yaratıcı drama, eğitimde yaratıcı drama" gibi kullanımları olan bu kavram bu çalışmada "yaratıcı drama" olarak kullanılmıştır. 
1. Yaratıcı drama eğitimi almak (demokratik kitle örgütlerinin verdiği liderlik/eğitmenlik programlarına, üniversitelerde yürütülen lisansüstü programlara başvurmak),

2. Yaratıcı dramanın alan bilgisine (özellikle tiyatro ve eğitim konusunda olmakla birlikte sanat, sosyoloji, psikoloji, felsefe vd.) sahip olmak,

3. Yaratıcı drama uygulamalarıyla ilgili güncel gelişmeleri takip etmek (kongre, seminer ve atölyelere katılmak, alanla ilgili süreli yayınları takip etmek),

4. Yaratıcı drama uygulama becerisine sahip olmak (yapılandırma, tasarlama, planlama, değerlendirme), uygulama ile ilgili deneyimlerini arttırmak, yaptığı uygulamalara eleştirel bir gözle bakmayı öğrenmek,

5. Yaratıcı dramanın (demokratik kültür, estetik bakış açısı ve yaratıcılık, geliştirme, bütün katılımcılara eşit mesafede olma, kalıplara sahip olmadan düşünme) gerektirdiği temel nitelikler konusunda kendi tutumlarını geliştirmek.

Türkiye'de yaratıcı drama araştırmalarının büyük çoğunluğunu yöntem boyutuna odaklanan çalışmalar oluşturmaktadır. Türkiye'de 1985-2012 yılları arasında yaratıcı alanında yapılmış 1144 çalışmanın \% 72,7'si yaratıcı dramanın yöntem boyutuyla ilgilidir (Adıgüzel, 2016, s. 11). Bunun içine, yaratıcı dramanın hem yöntem hem ders boyutunu ele alan çalışmalar da katılırsa oran \% 77'ye çıkmaktadır (Adıgüzel, 2016, s. 11). Bunun yanında, yaratıcı dramanın akademik başarıya, dersler karşı tutumlara, beceri geliştirmeye etkisini inceleyen birçok meta-analiz araştırmasında da yaratıcı dramanın etkili bir yöntem olduğu ortaya konmuştur.

Yaratıcı dramanın akademik başarıya etkisini ele alan meta-analiz araştırmalarında, drama temelli öğretimin eğitsel ortamlardaki başarı üzerinde pozitif ve kayda değer bir etkisinin olduğu (Patall ve Cawthon ve Steingut, 2014), yaratıcı dramanın öğrencinin akademik başarısını artırmış olduğu (Ulubey ve Toraman, 2015), yaratıcı dramanın akademik başarı üzerinde kayda değer bir etkisinin bulunduğu (Batdı ve Batdı, 2015), derslerde yaratıcı drama kullanımının akademik başarıyı etkileme düzeyinin yüksek olduğu (Akdemir ve Karakuş, 2016) sonuçlarına ulaşıldığı görülmektedir.

Ek olarak, yaratıcı dramanın genel anlamda akademik başarıya etkisini ele alan meta-analiz çalışmalarının yanında, belli bir disiplindeki akademik başarıya etkisini alan meta-analiz araştırmaları da bulunmaktadır.

Çelik (2013), ilköğretim matematik derslerinde kullanılan alternatif öğretim yöntemlerinin akademik başarıya etkisini araştırdığı meta-analiz araştırmasında ilköğretim matematik derslerinde kullanılan alternatif öğretim yöntemlerinin, akademik başarı açısından öğretmen merkezli öğretim yöntemine göre daha etkili olduğunu ortaya koymuştur. Araştırmacının alternatif yöntemler içerisinde değerlendirdiği yöntemlerden bir tanesi de yaratıcı dramadır.

Cantürk-Günhan'ın (2016) Türkiye'de uygulanan drama temelli eğitimin matematik başarısına etkisini araştırdığı meta-analiz araştırmasının sonuçlarına göre; yaratıcı drama yönteminin matematik başarısının artırılmasında oldukça etkili bir yöntem olduğu ortaya çıkmıştır. Ayrıca aynı araştırmanın bir diğer sonucuna göre; yaratıcı drama temelli eğitimin öğrencilerin öğrenim kademesine göre incelendiğinde akademik başarılarda en yüksek etki büyüklüğünün okul öncesi ve birinci kademede olduğu saptanmıştır.

Yaratıcı dramanın akademik başarıya etkisini ele alan meta-analiz araştırmalarına ek olarak, bir de yaratıcı dramanın derslere karşı tutum, öğrenci becerilerinin geliştirilmesi üzerindeki etkisinin 
ne olduğunu ele alan meta-analiz araştırmaları bulunmaktadır. Toraman ve Ulubey (2016), yaratıcı dramanın derse yönelik tutum üzerindeki etkisini ele aldıkları meta-analiz araştırmasında yaratıcı dramanın derslere yönelik tutumu olumlu yönde etkilediği sonucuna ulaşmıştır. Ulubey'in (2018), bir yöntem olarak yaratıcı dramanın beceri geliştirmeye etkisini incelediği meta-analiz araştırmasında yaratıcı dramanın beceri geliştirmede etkili olduğu sonucuna varılmış, ancak bu durumun okul öncesi, lise ve yükseköğretim düzeyinde sınırlı kaldığı da ayrıca belirtilmiştir. Uygulandığı her alanda başarıyı artırması yaratıcı dramanın etkili bir yöntem olarak tanımlanması için yeterli sayılabilir. $\mathrm{Bu}$ bağlamda, sözü edilen araştırmalarda ele alınan uygulamalar bir eğitmen tarafından gerçekleştirildiği için uygulamaları gerçekleştiren eğitmenlerin de belli bir yetkinlik düzeyinde olduğu sonucuna varılabilir.

Yaratıcı dramayla ilgili çalışmaların bu denli etkili olduğuna ilişkin yapılan araştırmaların aksine alanyazında yaratıcı drama dersinin planlanmasına yönelik yeterlilikle ilgili yapılan çalışmalarda öğretmenlerin ve öğretmen adaylarının kendilerini bu konuda yetersiz, orta yeterlikte veya ara sıra yeterli gördükleri sonucuna ulaşan araştırmalar göze çarpmaktadır. Çetingöz ve CantürkGünhan (2011), okulöncesi öğretmen adaylarının yaratıcı drama süreçlerini planlama becerilerinin geliştirilmesine dönük yaptıkları araştırmanın uygulama süreci öncesinde okulöncesi öğretmen adaylarının yaratıcı drama dersini planlama konusunda bilgi eksikliğine sahip olduklarını saptamıştır.

Akyel ve Çalışkan (2013), okulöncesi eğitim kurumlarında görev yapan öğretmenlerin drama yöntemi yeterliliklerinin değerlendirilmesine ilişkin çalışmalarında, öğretmenlerin drama süreçlerini planlamada kendilerini ara sıra yeterli bulduklarını ortaya koymuşlardır. Elitok-Kesici (2014), sınıf öğretmenlerinin drama dersini nasıl işledikleri ve bu dersi işlerken karşılaştıkları güçlükler ve eksikliklerin neler olduğunu ortaya koyma amacıyla gerçekleştirdiği araştırmasında öğretmenlerin drama dersini işlerken kendilerini yetersiz hissettiklerini belirtmektedir. Çelikkaya ve Koç’un (2015), öğretmenlerin sosyal bilgiler dersinde drama yöntemi uygulama yeterlilikleri üzerine yaptıkları araştırmanın sonucunda elde edilen verilerde en düşük ortalama "Drama yöntemine uygun ders planı yaparım.” ifadesine ait çıkmıştır. Şahin'in (2017) yaratıcı drama dersini almış ve almamış olan sınıf öğretmeni adaylarının öz-yeterliliklerini karşılaştırdığı çalışmasında da adayların yaratıcı dramayı yöntem olarak kullanma konusundaki yeterlilikleri orta düzeyde çıkmıştır.

Özer, İlhan ve Taşkaya (2018) tarafından sınıf öğretmenlerinin drama yöntemine ilişkin görüşlerinin incelendiği araştırma kapsamında görüşme yapılan öğretmenlerin \%60’ının kendilerini uygulama konusunda ya yetersiz ya da orta yeterlilikte gördükleri ortaya çıkmıştır. Şahin (2018)'in sınıf öğretmenliği ve Türkçe öğretmenliği adaylarıyla yaptığı bir başka çalışmada ise öğretmen adaylarının yaratıcı drama konusundaki öz-yeterlilikleri orta düzeyde çıkmıştır. Kuşdemir-Kayıran (2018), öğretmen adaylarının yaratıcı drama yöntemini kullanmaya dönük öz-yeterlik algılarını ve yaratıcı dramaya ilişkin tutumlarını geliştirerek, dramayı planlayabilme ve uygulayabilme süreçlerine katkı yapmak amacıyla gerçekleştirdiği araştırma için yaptığı ön görüşmede öğretmen adaylarının en çok yaratıcı drama dersini planlama konusunda sıkıntı yaşadıkları bulgusuna ulaşmıştır.

Yaratıcı drama çalışmalarının büyük çoğunluğunun yöntem boyutuna odaklanıyor olması yaratıcı drama eğitmeninin niteliğinin ve yeterliklerinin takip edilmesini bir kat daha önemli kılmaktadır. Okulöncesinden yükseköğretime kadar geniş bir yelpazede yöntem olarak kullanılan yaratıcı dramanın, alanyazındaki ilgili çalışmalar doğrultusunda, öğretmenlerin ve öğretmen adaylarının planlama ve uygulama becerilerinin geliştirilmesi, bu konuyla ilgili sorunların ortaya 
konması da var olan uygulamaların niteliğinin artırılması açısından öncelikli olarak ele alınması gereken bir konu olarak öne çıkmaktadır. Bu çalışmanın problemini yaratıcı dramayı ilkokul düzeyinde bir yöntem olarak kullanacakları öngörülen sınıf öğretmenliği adaylarının yaratıcı drama dersini planlamada sorunlarla karşılaşıp karşılaşmadıklarını ortaya koymak oluşturmaktadır. Alanyazında da belirtildiği üzere öğretmen ve öğretmen adaylarının yaratıcı drama ile ilgili kendilerini en yetersiz gördükleri konu planlama ve uygulama becerileridir. Buradan yola çıkarak, çalışmanın amacının, öğretmenlik eğitimi alan adayların yaratıcı dramayı planlama süreçlerinde karşılaştıkları sorunları belirlemek ve incelemek olarak gösterilebilir.

$\mathrm{Bu}$ sorunların belirlenmesinin öğretmen adaylarının ilerideki uygulamalarının yetkinlik düzeyine katkı yapabileceği var sayılmıştır. Çalışmanın amacı doğrultusunda aşağıdaki soruya yanıt aranmıştır:

Sınıf öğretmenliği adaylarının yaratıcı drama oturumları planlarken karşılaştıkları sorunlar nelerdir?

\section{Yöntem}

\section{Araștırma Modeli}

$\mathrm{Bu}$ çalışmada temel yorumlayıcı nitel araştırma deseni kullanılmıştır. Merriam (2002) sekiz farklı nitel araştırma deseni tanımlamıştır. Bu desenlerden biri “temel yorumlayıcı nitel araştırma"dır. Merriam (2002), temel yorumlayıcı deseni "genel amacı insanların yaşamlarını ve deneyimlerini nasıl anlamlandırdıklarını anlamak" olan bir çalışma olarak tanımlar. Bu amaç tüm nitel araştırmaların temelini oluştururken, Merriam, diğer stratejilere dayanan çalışmaların temel yorumlayıcı çalışmalarda bulunmayan ek amaçlara da sahip olduğunu belirtir (sözgelimi, gömülü teoride teori geliştirmek, fenomenolojideki bir olgunun özünü tanımlamak, vd.). Merriam için temel çalışmalar, diğer stratejilerin kendilerine özgü özelliklerini paylaşmayan çalışmalardır. Temel yorumlayıcı nitel araştırmanın kendinde özgü doğasını anlaşılır kılmak adına Batılı olmayan bir kültürde yetişkin öğrenmesini inceleyen bir çalışmadan örnek vermektedir. Bu çalışmada kültür, verileri yorumlarken önemli bir kaynak olmasına karşın, örnek verdiği çalışma etnografi deseniyle yapılmış bir çalışma değildir. Çünkü çalışmanın etnografi deseninde olabilmesi için araştırmacının o toplulukla uzun süre kalması veya katılımcı bir gözlemci olarak sürece dahil olması gerekirdi. Bu çalışmada, yalnızca yetişkin öğrenmesinin nasıl gerçekleştiğine odaklanılmıştır. Kültürü tanımlamak başat amaç değildir. Çalışmanın asıl amac1, o kültürdeki yetişkinlerin öğrenme sürecini anlamaktır. Temel yorumlayıcı nitel araştırma (basic interpretive qualitative study), araştırmacının katılımcıların bir anlamı ya da fenomeni nasıl oluşturduğunu anlamaya çalışmasıyla ilgilendiğinde kullanılabilir. Temel yorumlayıcı nitel araştırma; görüşmelerden, gözlemlerden, doküman analizinden (katılımcıların yazılı süreç çıktıları gibi) yararlanan tümevarımsal bir araştırma stratejisidir (Merriam, 2002). Bu bağlamda, temel yorumlayıcı nitel araştırma yorumlayıcı paradigmaya uygun olan ancak birtakım ek amaçların yerine getirilmesine gereksinim duyulmayan nitel araştırmalar için kullanılan bir desendir.

$\mathrm{Bu}$ çalışma, yalnızca sınıf öğretmenliği adaylarının yaratıcı dramada planlama yaparken karşılaştıkları sorunları belirleyip inceleyerek anlamaya odaklanmaktadır. Bu bağlamda, çalışma 2015-2016 eğitim-öğretim yılının güz döneminde sınıf öğretmenliği programında zorunlu 
dersler arasında bulunan "Drama” dersi kapsamında gerçekleştirilmiştir. Dersin izlencesi gereği temel yaratıcı drama çalışmaları gerçekleştirildikten sonra temel kavramlar ve temel tekniklerin öğretilmesine geçilmiştir. Bunun ardından ise yaratıcı dramada planlama uygulamalı ve kuramsal olarak aktarılmıştır. Dersin son haftalarında ise öğretmen adayları belirledikleri konu ve kazanımlar odağında yaratıcı drama planları geliştirerek, bu planları sınıf arkadaşlarına uygulamışlardır. $\mathrm{Bu}$ süreçte, dersin öğretim elemanından da yardım almışlardır. Öğretmen adayları, yaratıcı drama ders planlarını geliştirirlerken eş zamanlı olarak dersin öğretim elemanı tarafından hazırlanmış görüşme formlarını da doldurmuşlardır. Öğretmen adaylarının görüşme formlarını ders planlarını geliştirirken doldurmalarındaki amaç yaşadıkları sorunları anlık olarak not düşmelerini sağlamaktır. Dersin sonunda tüm ders planı örnekleri değerlendirme için alınırken görüşme formları da beraberinde toplanmıştır. Bu sürecin ardından, görüşme formları ve planlar beraber değerlendirilerek öğretmen adaylarının planlamada ne gibi sorunlarla karşılaştıkları ortaya konmaya çalışılmıştır. Bu bağlamda, çalışma sürecinde temel yorumlayıcı nitel araştırmaya uygun olarak görüşme ve doküman analizinden yararlanılmış olup, öğretmen adaylarının yaratıcı drama planlama sürecinde yaşadıkları sorunları nasıl anlamlandırdıkları ortaya çıkartılmaya çalışılmıştır.

\section{Çalışma Grubu}

Araştırmanın çalışma grubunu 2015-2106 eğitim-öğretim yılı güz döneminde bir devlet üniversitesinin eğitim bilimleri fakültesinde öğrenim görmekte olan ve beşinci yarıyıllarında "Drama" dersi almakta olan otuz beş sınıf öğretmenliği üçüncü sınıf öğrencisi oluşturmuş̧tur. Çalışma grubunun öğretmen adaylarından oluşmasının nedeni, öğretmen adaylarının yaratıcı dramayı ileriki yıllarda öğretmenlik mesleğini icra ederlerken derslerinde bir yöntem olarak kullanacak olmalarıdır.

\section{Veri Toplama Araçları}

Çalışmanın ana veri toplama aracı olarak yapılandırılmış görüşme formu kullanılmıştır. Yapılandırılmış görüşme formu yaratıcı drama sürecini planlarken bağlı kalınan ölçütler ve planlamada karşılaşılan sorunları ele alan kapalı uçlu iki sorudan oluşturulmuştur. Görüşme formu oluşturulurken iki yaratıcı drama alan uzmanından ve dilsel denetim için de bir Türk dili uzmanından görüş alınmıştır. Alınan görüşler doğrultusunda gerçekleştirilen düzeltmelerin ardından görüşme formuna son biçimi verilmiştir. Yapılandırılmış görüşme formunda yer alan iki soru aşağıdaki gibidir:

1. Atölye içeriğini geliştirirken herhangi bir zorluk yaşadım mı? Eğer bir zorlukla karşılaştıysam, bunlar nelerdi (ekonomik sıkıntılar, alana ilişkin bilgi yetersizliği, motivasyon eksikliği vd.)?

2. Atölyenin içeriğini geliştirirken oyun seçiminde, dramatik durum yazarken, araç-gereç belirlerken, varsa eğer önceden yazılmış bir metni, hareketli ya da hareketli olmayan bir görseli (fotoğraf, resim, video vd.) seçerken herhangi bir ölçüte bağlı kaldım mı? Kaldıysam bunlar nelerdi (kazanımla ilişkisi, eğitim etiği, işlevselliği vd.) ?

Yapılandırılmış görüşme formuna ek olarak, öğretmen adayları tarafından hazırlanmış olan yaratıcı drama ders planları da doküman türünde veri toplama araçları olarak değerlendirilmiştir. Bu planlardan öğretmen adayları tarafından görüşme formuna verilen yanıtların yorumlanmasında yararlanılmıştır. 


\section{Verilerin Toplanması}

Çalışmanın verileri görüşme ve doküman analizi yoluyla toplanmıştır. Görüşme yoluyla toplanan veriler için oluşturulmuş olan yapılandırılmış görüşme formu dönemin başında öğretmen adaylarına ulaştırılmıştır. Öğretmen adayları, dersin kapsamında yaratıcı drama ders planı hazırlamakla yükümlü tutulmuşlardır. Öğretmen adayları görüşme formunu kendi planlarını hazırlarlarken doldurmuşlardır. Böylece öğretmen adaylarının yaratıcı drama ders planlarını geliştirirlerken karşılaştıkları sorunları anlık olarak not etmeleri amaçlanmıştır. Doküman analizi yoluyla toplanan verileri öğretmen adaylarının yaratıcı drama ders planları oluşturmuştur.

\section{Verilerin Analizi}

Çalışmanın verileri betimsel analiz tekniği kullanılarak çözümlenmiştir. Betimsel analizde, elde edilen veriler, daha önceden belirlenen temalara göre özetlenir ve yorumlanır (Yıldırım ve Şimşek, 2013). Öğretmen adaylarından görüşmeler yoluyla toplanan veriler, öğretmen adaylarının yaratıcı drama planlama sürecinde karşılaştıkları sorunlara ilişkin görüşlerini ortaya koyacak biçimde çözümlenmiştir. Buna göre görüşme sonunda elde edilen verilerin deşifresinden sonra, veriler satır satır kodlanmış, ortak kodlar ortak kategoriler altında birleştirilmiş, son olarak da ortak kategoriler önceden belirlenmiş temalarla ilişkilendirilmiştir. Gerekli yerlerde öğretmen görüşlerinden doğrudan alıntılar verilerek yorumlanmıştır. Bunun yanında, çalışmanın sağlamlığını artırmak için bir başka uzmana da veriler kodlatılmıştır. Kodlama yapan uzmanla, araştırmacının kodları karşılaştırılarak aralarında tutarlılık sağlanmaya çalışılmıştır.

Planlama sürecinde neyin sorun olduğu belli bir yaratıcı drama planlama yaklaşımının ilkelerine bağlı kalınarak tanımlanmıştır. Bu planlama yaklaşımı, öğretmen adaylarının da kendi planlarını geliştirirken bağlı kaldıkları yaklaşımdır. Türkiye'de yaratıcı drama dersini veya yöntemini planlamada yaygın olarak kullanılan aşamalılık sistemi ve yapılandırma yaklaşımı Ömer Adıgüzel'e aittir. Bu yaklaşım, araştırmacı tarafından "Yaratıcı Dramayı Planlama ve Yapılandırmada Adıgüzel Yaklaşımı” olarak adlandırılmıştır. Ömer Adıgüzel, Türkiye'de yaratıcı drama alanında gerçekleştirilen birçok akademik çalışmada kullanılan bu yaklaşımı ilk olarak 2002 yılında KKTC'de düzenlenmiş olan "11. Eğitim Bilimleri Kongresi”nde sunduğu "Eğitim Bilimlerinde ve Sanat Eğitiminde Yöntem, Disiplin ve Sanatsal Boyutlarıyla Yaratıcı Drama” başlıklı bildirisiyle açıklamış; 2006 yılında "Yaratıcı Drama Dergisi”nin ilk sayısındaki "Yaratıcı Drama Kavramı, Bileşenleri ve Aşamaları" başlıklı makalesinde geliştirdiği planlama yaklaşımına ilişkin daha ayrıntılı bilgiler aktarmıştır. Adıgüzel'in yaklaşımının geçerliliği dünyadaki farklı yaratıcı drama planlama yaklaşımlarına bakılarak da anlaşılabilir.

Dünyada yaratıcı drama süreçlerinin planlanma ve yapılandırılma süreçleri, küçük ayrıntılar dışında birbiriyle tutarlılık göstermektedir. Yaratıcı drama alanının ilk öncülerinden Winfred Ward'un planlama yaklaşımı alanda uzun yıllar etkili olan bir planlama yaklaşımıdır. Ward, ders planlama konusunda doğrusal/çizgisel bir yaklaşım benimsemiş ve çocukların sıklıkla karşılaşabileceği dizi etkinliği belli bir sırayla sunmayı önermiştir: "Sözü edilen dizi duyu-algı/yoğunlaşma etkinlikleriyle başlayıp devinim/pantomim, diyalog, karakterize etme ve doğaçlama/ öykü canlandırmayla devam eder" (Wright, 1985 'ten akt; Taylor, 2003). Ward'un belli bir sırayı izleme mantığı, belli bir aşamalılığın da göstergesi olarak algılanabilir. Kase-Polisini'nin (1989'dan akt; Taylor 2003) anlayışı da Ward ile benzerlik göstermektedir: "Plan, önceden açıkça belirlenmiş hedefleri, 1sınma etkinliği, kullanılacak kaynak materyalleri, aynı hedefleri gerçekleştirmeye yarayacak alternatif kaynak materyalleri, uygulanacak teknikleri ve rahatlama etkinliği içermelidir”. 
Fleming (2003) kendi yaklaşımındaki plan künyesinde, kazanımlara, içeriğin odağının ne olduğuna ve süreçte kullanılacak araç-gereçlere; yaratıcı drama süreci aşamaları olarak "1sınmaoyunları/ikili doğaçlamalar/grup tartışması/çalışmaların gönüllü sunulması/değerlendirme" başlıklarına yer vermiştir. Toyle ve Prendville (2000) ise kendi yaklaşımlarının plan künyesinde, araç-gereçler ve uyaranların, açıkça belirtilmiş öğrenme kazanımlarının önemine dikkat çekmiş; ancak yaratıcı drama sürecinin planlanmasına dönük tam bir aşamalılık ortaya koymamıştır. Bunun yerine, dramatik kurgunun bileşenleriyle- yaratıcı drama sürecinde yapılması gerekenleri karıştırdığ1 bir "olması gerekenler" listesi hazırlamıştır: "Bağlamlar-zamanı ve mekanı sınırlandırma/Roller (hem öğretmen hem öğrenci)/Odak/Anahtar Anlar”.

Toyle ve Prendville'nin dramatik yapıya ve yaratıcı dramanın canlandırmalarla ilerleyen özelliğine dikkat çektiği ifade edilebilir. McCaslin (2016) de kitabında verdiği oturum örneklerinde Adıgüzel gibi işlevsel ve yalın bir planlama yaklaşımı sunmaktadır. McCaslin, öğrenme kazanımlarına ayrı bir bölüm olarak yer verirken, süreci hazırlık ve işleyiş olarak ikiye ayırmıştır. İşleyişi de kendi içerisinde canlandırma ve değerlendirme bölümlerine ayırmak olanaklıdır. Yaratıcı drama alanındaki çeşitli planlama yaklaşımları değerlendirildiğinde; Adıgüzel'in yaklaşımını uluslararası planlama ve yapılandırma basamaklarını içeren, yaratıcı dramanın alan bilgisine sahip herkesin kullanabileceği işlevsel bir yaklaşım olarak tanımlamak mümkündür.

Adıgüzel'in (2006) yaratıcı drama çalışmaları için kendi deyimiyle "geliştirilen ve önerilen" aşamaları aşağıdaki gibidir:

- Hazırlık-Isınma Çalışmaları

- Canlandirma

- Değerlendirme-Tartışma.

Adıgüzel (2018) kendi planlama ve yapılandırma yaklaşımının plan künyesinde ise "Ders, konu, kazanımlar, süre, sınıf (çalışılacak grup), araç-gereçler, yöntem ve teknikler” başlıklarına yer vermiştir. Adıü̈zel'in (2018 s.134-135) planlama ve yapılandırma yaklaşımının genel çerçevesi aşağıdaki gibidir:

"Yaratıcı drama çallşmalarında ne, niçin, ne zaman, nasıl, nerede, kim, kime (kimlerle) gibi sorulara verilecek yanıtlar, yaratıcı drama sürecinin tüm yapılandırmasinı ya da izlenecek aşamalar zincirini oluşturur.

Yaratıcı drama çalışmalarında önemli olan saptanan amaçlara göre işlenecek konunun uygun olan gruba ve gereken zamanda verilirken tüm etkinlikler arasında bir bağlantının olmasl, etkinliklerin bir birini destekleyen ve bütünleyen bir özelliğinin sahip olması ve katılımcıda içselleştirilmesi düşünülen kazanımlara ulaşmada etkili olup olmayacağının belirlenmesidir."

"Yaratıcı Dramayı Planlama ve Yapılandırmada Adıgüzel Yaklaşımı" örnek yaratıcı drama planı şablonuna makalenin ekinde yer verilmiştir. Bu çalışmaya katılan öğretmen adaylarına ders kapsamında aktarılan ve öğretmen adaylarının ders planlarını geliştirirken bağlı kaldıklarını yapılandırma yaklaşımı Adıgüzel'e ait olan yaklaşımdır. Öğretmen adaylarının planları ve planlamada karşılaştıkları sorunlara ilişkin elde edilen veriler Adıgüzel'in yaklaşımı ölçüt alınarak değerlendirilmiş ve yorumlanmıştır. 


\section{Bulgular}

Bulgular önceden belirlenmiş iki tema altında toplanmıştır. Bu temalar; "Öğretmen Adaylarının Yaratıcı Drama Planı Oluştururken Bağlı Kaldıkları Ölçütler” ve “Öğretmen Adaylarının Yaratıcı Drama Planı Oluştururken Karşılaştıkları Sorunlar”dır. Planlama sürecinde bağlı kalınan ölçütlerin belirlenmesi, öğretmen adaylarının oluşturdukları yaratıcı drama planlarının araştırmada bağlı kalınan planlama yaklaşımına uygun olup olmadıklarını değerlendirmek açısından gerekli görülmüştür.

\section{1. Öğretmen Adaylarının Yaratıcı Drama Planı Oluştururken Bağlı Kaldıkları Ölçüitlere İlişkin Bulgular}

Öğrencilerin yaratıcı drama planı geliştirirken bağlı kaldıkları ölçütler teması altında oluşmuş kategorilere bakıldığında; "öğrencinin gelişim düzeyine uygunluk", "aşamalılığa ve kazanıma/kazanımlara bağlı kalmak" başlıklı alt kategorilerin ortaya çıktığı görülmektedir. Öğretmen adaylarının yaratıcı drama planı oluştururken bağlı kaldıkları ölçütler başlıklı temaya ait alt kategoriler ve bu alt kategorilere ait kodlar öğretmen adaylarının görüşlerinden yapılan doğrudan alıntılarla yorumlanarak sunulmuştur. Aşağıda temanın iki alt kategorisini gösteren tablo bulunmaktadır:

Tablo 1. Öğretmen Adaylarının Yaratıcı Drama Planı Oluştururken Bağlı Kaldıkları Ölçütler

\begin{tabular}{cl}
\hline $\begin{array}{c}\text { Öğretmen Adaylarının } \\
\text { Yaratıcı Drama Planı Oluştururken } \\
\text { Bağlı Kaldıkları Ölçütler }\end{array}$ & Öğrencinin Gelişıim Düzeyine Uygunluk \\
\cline { 2 - 2 } & Aşamalılığa ve Kazanıma/Kazanımlara Bağlı Kalmak \\
\hline
\end{tabular}

Öğretmen adaylarının yaratıcı drama planı oluştururken bağlı kaldıkları ölçütler temasının ilk alt kategorisi "Öğrencinin Gelişim Düzeyine Uygunluk" tur. Bu kategorinin altında toplanan ortak kodlar aşağıdaki gibidir:

Tablo 2. Öğrencinin Gelişim Düzeyine Uygunluk

\begin{tabular}{cl}
\hline $\begin{array}{c}\text { Öğrencinin } \\
\text { Gelişim Düzeyine } \\
\text { Uygunluk }\end{array}$ & $\begin{array}{l}\text { Seçilen Oyun, Etkinlik ve Canlandırmaların Öğrencinin Gelişim Düzeyine } \\
\text { Uygunluğu }\end{array}$ \\
\cline { 2 - 2 } & Öğrencinin Gelişim Düzeyine Uygun Dil Kullanımı \\
\cline { 2 - 2 } & Öğrencinin Gelişim Düzeyine Uygun Materyal Seçimi \\
\hline
\end{tabular}

$\mathrm{Bu}$ alt kategoride, öğrencilerin yaratıcı drama planı oluştururken bağlı kaldıkları ölçütleri karşılayan kodlar; seçilen oyun, canlandırma ve etkinliklerin öğrencinin gelişim düzeyine uygun olması, öğrencin gelişim düzeyine uygun materyalin seçimi ve dilin kullanımı başlıklarında toplanmıştır. Öğretmen adaylarının yaratıcı drama oturumlarını geliştirirken hedef kitle olarak belirledikleri yaş grubunun bilişsel ve dilsel gelişim düzeyini de dikkate aldıkları görülmektedir:

"Dramatik durumu yazarken ögrencinin bilişsel seviyesine göre yazmaya dikkat ettim. Oyun seçimlerinde ilk olarak çocukların farkındalık bilincinin gelişimine dikkat ettim. Öğrencilerin anlayabileceği bir dil kullanmaya çalıştım. Aynı zamanda öğrenciyi slkmadan eğlenceli bir şekilde öğrenmelerini ve bu durumlara çözüm yolları bulmalarını sağlamaya çalıştım.'” (ÖA1) 
"Dramatik durumu yazarken öğrencinin bilişsel seviyesine göre yazmaya dikkat ettim. Onların anlayabileceği bir dil kullanmaya gayret ettim. Ayn zamanda etkinlikler yaparken öğrencinin ilgisini çekecek, günlük hayatta karşılarına çıkabilecek ve onlara bu saygı kavramı bilincini aşılayabilecek etkinlikler, durumlar seçmeye çalıştım. "(ÖA6)

Atölyelerde, katılımcı grubun dilsel gelişim düzeyine uygun bir eğitmenlik tavrı belirlemek önemlidir. Çünkü seçilen oyunlar, canlandırma durumlarını birbirine benzer olsalar da bu etkinliklerin katılımcı gruba aktarım dili yaş grubuna göre değişir. Ĕ̆itmen, okulöncesi dönem çocuklarıyla yapılan bir atölyede daha kısa, yalın sözcükler seçerek yönerge vermek durumundayken, yetişkinliklerle yapılan atölyelerde daha uzun, karmaşık ve yetişkinliklerin dağarcığına uygun sözcükler seçebilir.

Öğretmen adaylarının özellikle bağlı kaldıklarını ifade ettikleri bir diğer ölçüt ise materyal seçimi olmuştur:

“... canlandırmanın ikinci etkinliğimde kullandı̆̆ım görsellerde öğrencileri duygusal anlamda zedeleyecek olmamasına dikkat ettim. Kullandığım görsellerde toplumun engelli bireylerin hayatını zorlaştıracak durumlarını ele aldım. Öğrencilerden bu olumsuz durumlarla nasıl başa çıkacaklarını kendilerinin bulmasını istedim. Bu yüzden ikinci etkinlikte ögrencilere dramatik durum vermedim. Seçtiğim her iki kazanıma bağlı kalarak atölyemi oluşturdum." (ÖA4)

ÖA4'ün örnek ifadesinden yola çıarak öğretmen adaylarının çoğunluğunun materyal seçerken uygulama yapacakları yaş grubunun duygusal ve psikolojik gelişim düzeylerini dikkate aldıkları, işlenen konuyla ilgili yanlış duyarlılık geliştirmeye yol açabilecek materyal kullanımlarından kaçındıkları ifade edilebilir.

"Videoyu seçerken o yaş grubuna uygun olmasina dikkat ettim. Çocuk edebiyatından da öğrendiğim üzere 'çocuğa görelik ilkesi' çok önemli. Video seçerken belirlediğim konudan (şiddetle ilgili) dolayı da çok dikkatli olmam gerekiyordu. Araç-gereç seçerken çocuğun dikkatini çekebilecek malzemeler olmasına dikkat ettim (renkli kâğıt, boya kalemi vb.) Dramatik durum seçerken canlandırmalar esnasında çocukların birbirine zarar vermeyeceği durumlar olmasına dikkat etmeye çalıştım. Çatışmalarda her iki tarafin da haklı olabileceği durumları seçmeye çalıştım." (ÖA8)

Yaratıcı drama süreçlerinde materyal (araç-gereç) seçimi atölye planlama künyesindeki birimlerden biri olup ele alınan konunun öğretilmesine yardımcı olacak biçimde belli bir amaç ve katılımcılara uygunluğu doğrultusunda seçilir. Öğretmen adayları materyal seçiminde yaş grubuna uygunluk ve materyalin konuyla ilişkili olması ölçütlerine bağlı kaldıklarını dile getirmişlerdir.

Öğretmen adayları yaratıcı drama ders planlarını geliştirirken bağlı kaldıkları bir diğer ölçütün kazanıma/kazanımlara ve aşamalara (1sıma-hazırlık/canlandırma/değerlendirme-tartışma) bağlılık olduğunu ifade etmişlerdir. Bu alt kategorinin kodlarına aşağıdaki tabloda yer verilmiştir: 
Tablo 3. Aşamalılı̆̆a ve Kazanım/Kazanımlara Bağlı Kalma

\begin{tabular}{cl}
\hline Aşamalıı̆̆a ve & Isınma-Hazırlık Aşaması \\
Kazanıma/ & Canlandırma Aşaması \\
Kazanımlara & Değerlendirme-Tartışma Aşaması \\
\cline { 2 - 2 } Bağlı Kalmak & Kazanıma Uygun Materyal Seçimi \\
\hline
\end{tabular}

Öğretmen adaylarının bu kategori için bağlı kaldıklarını vurguladıkları bu ölçütler; Adıgüzel planlama yaklaşımının da en önemli iki temel ilkesidir. Adıgüzel yaratıcı drama planlama yaklaşımında, belirlenen kazanım birbiriyle bağlantılı aşamalar halinde ele alınarak irdelenir. $\mathrm{Bu}$ yüzden, kazanımlara bağlı kalmakla, aşamaların birbiri arasındaki ve kazanımla ilişkisini gözetme konuları iç içe geçmiştir. Bunun yanında, öğretmen adaylarının 1sınma-hazırlık için seçtikleri etkinliklerin kazanımla ilişkili olmasına, sonraki aşamalara hazırlık niteliği taşımasına dikkat ettiklerini ifade etmişlerdir:

"Atölyenin içeriğini geliştirirken dersin başında kullandığım videonun, ısınma aşamasında kullandı̆̆ım oyunun, canlandırma aşamasında önceden yazılmış olarak aldığım ve kendim yazdığım dramatik durumların seçtiğim konuyla ve kazanımla ilişkili olmasına, hitap ettiğim yaş grubuna uygun olmasına ve ögrencilere kazandırmak istediğim bilinci en etkili şekilde kazandırmasina yani işlevsel olmasına dikkat ettim." (ÖA19)

"Isınma aşaması için düşündügüm oyunu kazanımla iliş̧kilendirdim. Dramatik durum yazarken çatışmalar içermesi, işlevselliği önemliydi." (ÖA22)

Öğretmen adayları, canlandırma aşamasında ise çatışma içeren dramatik durumlar yazma, bu dramatik durumlar içerisinde yer alan roller arasında güç-statü dengesini gözetme, dramatik durumların konularını gündelik yaşamla ilişkilendirmeye çalışma gibi ölçütlere bağlı kaldıklarını ifade etmişlerdir:

"Dramatik durum seçerken canlandırmalar esnasında çocukların birbirine zarar vermeyeceği durumlar olmasına dikkat etmeye çalıştım. Çatışmalarda her iki tarafin da haklı olabileceği durumları seçmeye çalıştım." (ÖA8)

Öğretmen adaylarının en az değindikleri aşama ise değerlendirme aşaması olmuştur. Bu aşama için görüş belirten öğretmen adayları kazanıma ulaşılıp ulaşılmadığını değerlendirmek adına ara değerlendirmeler de yaptıklarını, değerlendirme aşaması için ise sorular hazırladıklarını ifade etmişlerdir:

“...Canlandırmalarımda çatışmalara ve konumla alakalı olmasına, ısınma aşamasında canlandırmaya hazırlık yaptırmaya buna temel oluşturmaya dikkat ettim. Değerlendirme aşamasında ise soruları hazırlarken ara değerlendirme ve genel değerlendirme yapmaya dikkat ettim." (ÖA5)

Öğretmen adaylarının planlama sürecinde dikkat ettikleri bir diğer nokta ise kazanıma uygun materyal seçimi olmuştur. Öğretmen adayları, atölyelerinde kullanmak için belirledikleri materyal ya da materyallerin uygulama yapılacak grubun gelişim düzeyine uygunluğunun yanında, kazanıma da hizmet etmesi gerektiği yönünde görüş belirtmişlerdir:

“Isınma aşaması için 'Pusulacık: Çocuklar İçin İnsan Hakları Eğitimi Kılavuzu'nun 'Erkekler Ağlamaz'metninden yararlandım. Birkaç kısmını değiştirdim. Metni seçerken konu ile bağlantılı olması için toplumsal cinsiyet eşitliği kazanımını sağlayacak oyunları seçtim” (ÖA9) 
ÖA9'un ifadesinde de görülebileceği gibi öğretmen adayı kendi oturumu için seçtiği materyali kazanımıyla ilişkisi odağında seçmiştir. Bunun yanında, yaratıcı drama süreçlerinin gereği olarak metni birebir sürece dahil etmek yerine, metin üzerinde değişikliklere gitmiştir. Öğretmen adayları seçtikleri materyallerin kazanıma uygunluğunu gözettikleri gibi seçilen materyalin aşılayabileceği değerleri ve görüşleri de gözetmişlerdir:

“...seçtiğim materyalleri kazanıma uygunluğu açısından değerlendirdim. İçerisinde ırkçı ya da yanlış kelimelerin geçip geçmediğine dikkat ettim. Ë̆itici olan çalışmalar seçmeye çalıştım." (ÖA27)

Öğretmen adaylarının kendi planlarını geliştirirken bağlı kaldıkları ölçütler değerlendirildiğinde, ölçüt alınmış yaratıcı drama yaklaşımının planlama ilkelerini asgari düzeyde karşılayan planlar geliştirmiş oldukları sonucuna ulaşılabilir. Adıgüzel'in yaratıcı drama planı yapılandırma yaklaşımında, belirlenen bir kazanımın birbiriyle bağlantıları kurulmuş üç aşama içerisinde sürece dayalı ele alınması söz konusudur. Öğrencilerin planlama yaparken bağlı kaldıkları ölçütler kazanıma uygunluk ve aşamalar arasında kazanımla ilişkili bağlantılar kurmuş olmaları planlamada asgari düzeyde dikkat edilmesi gereken noktaları göz önünde bulundurduklarını göstermektedir. Bunun yanında, öğretmen adaylarının görüşlerinden yapılan doğrudan alıntılarda gelişim düzeyine, kazanımlara, aşamalılığa bağl1lık gibi durumlarda bir iç içe geçmişlik durumunun söz konusu olduğu göze çarpmaktadır. Bu durum da öğretmen adaylarının planlarında uygun ölçütleri gözettiklerinin bir diğer göstergesidir. Çünkü belirlenen kazanımın atölyenin beraber gerçekleştirileceği katılımcı grubun özelliklerine uygun olması, seçilecek materyallerin ve etkinliklerin de katılımcı grubun özelliklerine uyumlu olmasını da beraberinde getirir. Bu ölçüte bağlı kalırken, bir yandan da aşamaların birbiriyle olan ilişkisinin kurulması da gerekir. Tüm bunlar gerçekleştirildiğinde ise planlamada bağlı kalınan ölçütler bir bütünü oluşturacak biçimde iç içe geçmiş olurlar.

\section{2. Öğretmen Adaylarının Yaratıcı Drama Planı Oluştururken Karşılaştıkları Sorunlara İlişkin Bulgular}

Öğretmen adaylarının yaratıcı drama planı geliştirme süreçlerinde karşılaştıkları sorunlar üç ana kategori altında toplanmıştır. Bu kategoriler, "motivasyon eksikliğinden kaynaklı sorunlar", "yaratıcı drama alanına ilişkin bilgi eksikliğinden kaynaklı sorunlar", "planda ele alınan konuya ilişkin bilgi eksikliğinden kaynaklı sorunlar" olarak belirlenmiştir:

Tablo 4. Öğretmen Adaylarının Yaratıcı Drama Planı Oluştururken Karşılaştıkları Sorunlar

\begin{tabular}{|c|c|c|}
\hline \multirow{2}{*}{$\begin{array}{c}\text { Öğretmen } \\
\text { Adaylarının } \\
\text { Yaratıcı Drama }\end{array}$} & \multirow{2}{*}{$\begin{array}{l}\text { Motivasyon } \\
\text { Eksikliğinden } \\
\text { Kaynaklı Sorunlar }\end{array}$} & Motivasyon Eksikliğine Neden Olan Çevresel Etkenler \\
\hline & & Motivasyon Eksikliğine Neden Olan Bireysel Etkenler \\
\hline \multirow{2}{*}{$\begin{array}{c}\text { Planı Oluştururken } \\
\text { Karşılaştıkları } \\
\text { Sorunlar }\end{array}$} & \multicolumn{2}{|c|}{ Yaratıcı Drama Alanına İlişkin Bilgi Eksikliğinden Kaynaklı Sorunlar } \\
\hline & \multicolumn{2}{|c|}{ Planda Ele Alınan Konuya İlişkin Bilgi Eksikliğinden Kaynaklı Sorunlar } \\
\hline
\end{tabular}

Motivasyon eksikliği, öğretmen adayları tarafından planlama sürecinde karşılaştıkları sorunlardan biri olarak sıkça ifade edilmiştir. Öğretmen adaylarının motivasyon eksikliğine ilişkin görüşleri "motivasyon eksikliğine neden olan çevresel etkenler" ve "motivasyon eksikliğine neden 
olan bireysel etkenler" olarak iki başlık altında toplanmıştır. Öncelikle motivasyon eksikliğine neden olan çevresel etkenler ele alınmıştır:

Tablo 5. Motivasyon Eksikliğine Neden Olan Çevresel Etkenler

\begin{tabular}{cl}
\hline Motivasyon & Yaratıcı Drama Dışındaki Derslerin Sorumlulukları \\
Eksikliğine & \\
\cline { 2 - 2 } $\begin{array}{c}\text { Neden Olan } \\
\text { Çevresel } \\
\text { Etkenler }\end{array}$ & Sınav Haftası Yoğunluğu \\
\hline
\end{tabular}

Öğretmen adayları, yaratıcı drama dışında aldıkları derslerde üstlendikleri sorumluluklar (ödev, sunum, alttan çok fazla ders almak vd.) ve yaratıcı drama planı ödevinin tesliminin sınav haftasına denk gelmesinden doğan bir motivasyon eksikliği yaşadıklarını ifade etmişlerdir:

"Yaşadığım en büyük zorluk motivasyon eksikliği oldu. Ama bu kesinlikle sizinle ya da ödevle ilgili bir durum değil, çevresel kaynaklyydı. Hem bir sürü sunumumuz vardı hem de bir sürü sınavımız... Bir türlü kendimi hazır hissedemedim ve başlayamadım. İstediğim gibi üzerinde uzun uzun düşünemedim. Bu durumu zamanı biraz daha verimli kullanarak aşmaya çalıştım. Ama işe yaramadl." (ÖA8)

ÖA8'in ifadesinden de anlaşılabileceği gibi öğretmen adaylarından bazıları planlama sürecinde yaşadıkları en büyük sorunu motivasyon eksikliği olarak tanımlamışlardır. Motivasyon eksikliğinin en önemli nedeni ise öğretmen adaylarının diğer derslerden kaynaklı yoğunluklarının yarattı̆̆ zaman sıkıntısıdır. Zaman sıkıntısı beraberinde yetiştirme kaygısını da getirdiği için öğretmen adayları planlarına ilişkin sağlıklı düşünemediklerini ifade etmişlerdir. Bunun yanında, öğretmen adaylarının sınavlardan, ödevlerden, sunumlardan kaynaklı yoğunluklarının yaratıcı drama alan bilgisini de yeterli düzeyde araştırmalarına engel olduğu söylenebilir. Bu durum mevcut motivasyon eksikliğini besleyen bir diğer kaynak olarak ortaya çıkmıştır:

"Atölye içeriğini geliştirirken çok zorlandım. Tam final haftasına denk gelmişti, zaman bulamadım, odaklanamadım, dramatik durum oluşturmakta zorlandım, alan bilgim yetersizdi, stres ve motivasyon düşüklüğ̈̈nden dolayı sağllklı düşünemedim. Bu yüzden parça parça ilerlemek zorunda kaldım. Öncesinde verilmiş olsaydı daha iyi bir şekilde keyifle hazırlayacağımı düşünüyorum. Stresli bir zamanda bu kadar yol alabildim. Ödevimi rahat, huzurlu ve zamanım bol olduğu günlerde hazırlamayı çok isterdim. Eminim daha güzel bir plan ortaya çıkardl." (ÖA27)

Öğretmen adayları, yaratıcı drama planlama sürecinde çevreden kaynaklı motivasyon eksiklikleri yaşadıkları gibi bireysel etkenlerden kaynaklı motivasyon eksikliği yaşadıklarını ifade etmişlerdir. Ev ve okul arasındaki mesafe, yorgunluk, aileyi uzun zamandır ziyaret edememe, kendine güvensizlik gibi geniş bir yelpazede konumlanan bireysel etkenlere aşağıdaki tabloda yer verilmiştir: 
Tablo 6. Motivasyon Eksikliğine Neden Olan Bireysel Etkenler

\begin{tabular}{ll}
\hline $\begin{array}{c}\text { Motivasyon } \\
\text { Eksikliğine } \\
\text { Neden Olan } \\
\text { Bireysel } \\
\text { Etkenler }\end{array}$ & Ev ve Okul Arası Mesafenin Uzak Olması \\
\cline { 2 - 2 } & Könem Sonu Yorgunluğu \\
\cline { 2 - 2 } & Aileyi Uzun Zamandır Ziyaret Etmemiş Olmak \\
\cline { 2 - 2 } & Odaklanamama/Dikkat Eksikliği \\
\hline
\end{tabular}

ÖA8 evi ve okul arasındaki mesafenin uzaklığından, yolun çok fazla zamanını almasından yakınırken, bu durumun yorgunluğa, zaman sıkıntısına neden olduğunu ifade etmektedir:

“...okuldan eve gelmem yaklaşık 1,5 saat sürüyor. Eve geldiğimdeyse aşırı yorulmuş oluyorum ve hiçbir şeye vakit ayıramıyorum. Ama zaman esnekliği sağladığını için daha fazla düşünme imkânım oldu, çok teşekkür ederim." (ÖA8)

ÖA16 ise düşündüklerini yazıya aktarma konusunda sıkıntılar yaşadığını ifade etmektedir:

"Kitapları okurken kafamda bir sürü olaylar,dramatik durumlar canlanırken keyifli olan bu süreç atölye içeriğiyle birlikte oluşturacağım ders planı sürecinde galiba o kadarda keyifli değildi. Bilgisayarın başına geçip düşündüklerimi,incelediklerimi yazmak beni oldukça zorladı.Bunun bence en büyük sebebi dönemin bitmesiyle birlikte üzerimde hissettiğim yorgunluğunda etkisiyle motivasyonumun son derece düşük olmaslydl."

ÖA32'nin bireysel motivasyon eksikliği ise alana ilişkin bilgi yetersizliğinden kaynaklanmaktadır. Bu durum öğretmen adayında iyi bir plan ortaya koyamama kaygısını beraberinde getirmektedir:

"Atölyeyi oluştururken bu alanda bilgi yetersizliğim olduğu ve konuya tam hakim olamayışım etkili olmuştur.Motivasyon tam olarak olamıyor ben de çünkü kendim çok iyi şeyler ortaya çılkarabilme konusunda açıkçası güvenmiyorum.Hemen bir kopukluk oluyor ben de bir şeyleri uzun sürede dikkatli bir şekilde yapma yeteneği yoktur.Dikkat dă̆llması çok olduğu için ben de bazı şeyleri unutabiliyorum maalesef." (ÖA32)

Bir başka öğretmen adayı ise yaşadığı motivasyon eksikliğini ailesini uzun zamandır ziyaret edememesine bağlamaktadır:

"Motivasyon eksikliği yaşadım açıkçası yaşamam nedeni ailemin yanına gidemememdi ama sonradan toparladım ve açıkçası iki hafta bu ödev için düşündüm. ” (ÖA21)

Öğretmen adaylarının yaşadıkları bireysel motivasyon eksikliği çok çeşitli etkenlere dayanmaktadır. Bunun yanında, motivasyon eksikliği teması göstermektedir ki iyi bir yaratıcı drama planı yapabilmek için alanla ilgili yeterli bilgi sahibi olmanın yanında planlamayı yapan kişiyi hem çevresel hem de bireysel olarak motive eden koşullarında bulunması gerekmektedir. 
Tablo 7. Yaratıcı Drama Alanına İlişskin Bilgi Eksikliğinden Kaynaklı Sorunlar

\begin{tabular}{|c|c|c|}
\hline \multirow{3}{*}{$\begin{array}{c}\text { Yaratıcı Drama } \\
\text { Alanına İlişkin } \\
\text { Bilgi Eksikliğinden } \\
\text { Kaynaklı Sorunlar }\end{array}$} & $\begin{array}{l}\text { Aşamaları } \\
\text { Yapılandırmayla İlgili }\end{array}$ & Isınma-Hazırlık Aşaması \\
\hline & Yaşanan Sorunlar & Canlandırma Aşaması \\
\hline & & Değerlendirme-Tartıșma Așaması \\
\hline
\end{tabular}

Öğretmen adayları planlama süreçlerindeki sorunlardan birini yaratıcı drama alanına ilişkin bilgi eksikliği olarak ifade etmişlerdir. Bu bilgi eksikliğinin özellikle aşamaları kendi içerisinde yapılandırırken, aşamaların birbirleriyle ilişkisini kurarken soruna neden olduğunu aktarmışlardır. Isınma-hazırlık aşamasında yaşanan en büyük sorunlardan biri kazanıma uygun oyun ve etkinlik bulmak, 1sınma-hazırlık aşamasını etkili ve dikkat çekici kılmak olarak öne çıkarken, canlandırma aşamasındaki en büyük sorunlardan biri olarak da dramatik durum yazmak olarak gösterilmiştir. Bunun yanında, öğretmen adayları değerlendirme-tartışma aşamasına da uygun değerlendirme etkinliği yazma konusunda sorunlar yaşadıklarını dile getirmişlerdir.

Öğretmen adaylarının yaratıcı drama alanına ilişkin bilgi eksikliğinden kaynaklı yaşadıkları sorunların başında aşamaların içeriğini yapılandırabilecek uygun etkinlikleri bulabilmek ve oluşturabilmek gelmektedir. ÖA1, 1sınma ve değerlendirme aşamalarına uygun, kazanımla ilişkili etkinlikler bulmakta zorlandığını ifade etmektedir:

"Atölye içeriğini geliştirirken özellikle ısınma ve değerlendirme aşamalarında öğrencinin ilgisini canlı tutacak ve ögrenciye yardımlaşma bilinci kazandıracak etkinlikler bulmak zamanımı aldı."

ÖA6 ise daha çok 1sınma-hazırlık aşamasını etkili hale getirme konusunda sıkıntı yaşadığını ifade etmektedir:

"Atölye içeriğini gelişstirirken birkaç yerde zorluklar yaşadım. Isınmayı etkili hale nasıl getiririm öğrencinin dikkatini nasıl çekerim diye düşündüm."

Öğretmen adaylarının yaratıcı drama alanına ilişkin bilgi eksikliklerinden kaynaklı yaşadıkları sorunların en önemlilerinden birisi de canlandırma aşamasının yapılandırılmasıdır. Canlandırma aşamasının yapılandırılması bağlamında en çok değinilen sorun ise dramatik durum yazamama olarak ifade edilmiştir.

Ancak dramatik durum yazamamak öğretmen adayları tarafından zaman zaman farklı gerekçelerle dile getirilmiş, bazı öğretmen adayları ise bu konuda hiç gerekçe belirtmemiştir. ÖA9, dramatik durum yazamamasının nedeni olarak atölyesinin konusuyla ilgili yalnızca gündelik yaşamdan edindiği bilgilere sahip olduğunu, konuyla ilgili akademik bilgiye sahip olmadığını ifade etmiştir. Bu durumun da dramatik durum yazmasında sorun yaşamasına neden olduğunu aktarmıştır:

"Atölye içeriğini geliştirirken zorluk yaşadım. Çünkü bu konuya yaşantı olarak hakimim fakat pek fazla bilgi birikimim yok. Canlandirmalarım için dramatik durum kurgularken zorluk yaşadım. Bunları aşmak için kaynaklara başvurdum."

ÖA22'nin dramatik durum yazma ile ilgili yaşadığı sorun ise daha çok dramatik kurgunun bileşenlerinin doğru bir biçimde bir araya getirilmesiyle ilgili görünmektedir. Özellikle ÖA22'nin ele aldığ 1 "şiddet" gibi çatışmalı toplumsal konularda, roller arasındaki statü, güç dengesini kurmak, dramatik kurgunun bileşenlerini bir araya getirmek daha da zorlaşmaktadır: 
"En çok ise dramatik durumlar yazarken zorlandım. Konu şiddet olunca şiddet uygulayan tarafin bir haklıliğı kalmiyor. Dramatik durum bu kez uygun olmuyor. Bu durumlarl yazarken başka konu mu seçsem diye bile düşündüm. Ama iyi kötü durumlart yazdım." (ÖA22)

ÖA27 ise dramatik durum yazarken yaşadığ1 zorluğu herhangi bir gerekçe belirtmeden doğrudan alan bilgisi eksikliğiyle ilişkilendirmektedir:

"Dramatik durum yazarken zorlandım .buda bu alanda fazla bilgi sahibi olmayışımdan kaynaklaniyor." (ÖA30)

Öğretmen adayları yaratıcı dramaya ilişkin alan bilgisi eksikliğinden kaynaklı sorunların yanında, "Planda Ele Alınan Konuya İlişkin Bilgi Eksikliğinden Kaynaklı Sorunlar" yaşadıklarını da ifade etmişlerdir. Aslında bu iki konudaki bilgi eksikliğinin birbirinden ayrı düşünülmemesi gerekir. İyi bir yaratıcı drama planı geliştirmek için hem yaratıcı drama alan bilgisine hem de atölyenin konusuna ilişkin bilgiye sahip olmak gerekir. Öğretmen adaylarının bu konuda yaşadıkları sorunlar iki başlık halinde ele alınabilir. Kimi öğretmen adayı atölyesinde ele aldığı konuya ilişkin bilgi eksikliğinden yakınırken, kimi öğretmen adayı ise atölyesinde ele aldığı konuya ilişkin başvurulacak kaynakların azlığından, kaynaklara ulaşmanın zorluğundan söz etmiştir.

"Atölye içeriğini geliştirirken zorluk yaşadım. Ayrıca seçtiğim konu zor geldi bu konuyla ilgili nasll bir atölye tasarlamam gerektiğini bulmakta zorlandım. "(ÖA34)

"Atölyeyi oluştururken bu alanda bilgi yetersizliğim olduğu ve konuya tam hakim olamayışım etkili olmuştur." (ÖA32)

ÖA34 ve ÖA32, yalnızca atölyelerine seçtikleri konuya ilişkin bilgi sahibi olmadıklarından sorun yaşadıklarını ifade etmişlerdir. ÖA22 ise daha kapsamlı bir araştırma gereksinimi duyduğunu ancak koşullardan kaynaklı başaramadığını ifade etmiştir:

"Evet yaşadım. Alan hakkinda sadece gündelik bilgilere sahiptim. Final sinavları olması sebebiyle daha kapsamlı ve daha çok araştırma yapacağım bir konuyu daha kısa bir zamanda ve sinırl kaynaklarla yaptım."

ÖA31 ve ÖA19 ise atölyenin konusuna ilişkin kaynakların azlığından ve bu kaynaklara ulaşımın zorluğundan kaynaklı sorunlar yaşadıklarını ifade etmişlerdir:

"Hocam aslında yaşadım. Bu konuyla ilgili ya çok az makale yazılmış ya da internette yoktu. Umarım sadece internete konmamıştır. Eğer yok bu konu üzerinde durulmamışsa zaten vay bizim halimize diyorum hocam. Baş etmeye çalıştım okulumuz kütüphanesinde de kaynak bulamadım. Birkaç kitap varmış ama onlarda alınmış daha getirilmemişti." (ÖA31)

"Atölye içeriğini oluştururken alanla ilgili bilgi yetersizliği konusunda sorun yaşadım. Sadece bu konuda yazılmış bir makale bulamadım. Bu nedenle konuyla iliş̧kili olduğunu düşündüğ̈̈m makalelerin hepsini okumak zorunda kaldım ve bilgileri onlardan parça parça aldım. Bu durum zamanımı aldı ama sonunda ödevimi bitirdim." (ÖA19)

Öğretmen adaylarının hem yaratıcı dramaya hem de ele aldıkları konuya ilişkin bilgi eksikliklerinin birbirini olumsuz etkilediği ifade edilebilir. Yaratıcı drama, katılımcıların yaşantılarından yola çıkar. Bu yaşantılar, dramatik bir kurgu içerisinde derinlemesine irdelenir. $\mathrm{Bu}$ yüzden, ele alınan konuya ilişkin derinlikli bilgiye sahip olmayan bir yaratıcı drama eğitmeni, o konuyla ilgili sağlam bir dramatik kurgu yaratmak konusunda da sorunlar yaşayabilir. Öğretmen adaylarının kendi yaratıcı drama planlarında ele aldıkları konulara ilişkin bilgilerinin olmamasının, dramatik durum yazma süreçlerini de olumsuz etkilediği söylenebilir. 


\section{Tartışma, Sonuç ve Öneriler}

Sınıf öğretmenliği adaylarının yaratıcı drama ders planı geliştirirken karşılaştıkları sorunların incelenmesi amacıyla gerçekleştirilen bu çalışmanın sonucunda, öğretmen adaylarının bu süreçte çeşitli sorunlar yaşadığı belirlenmiştir. Öğretmen adaylarının zorunlu olarak aldıkları drama dersi kapsamında gerçekleştirilen çalışmada, ilk adım olarak yaratıcı drama planlama süreçlerinde bağlı kaldıkları ölçütler "Yaratıcı Dramayı Planlama ve Yapılandırmada Adıgüzel Yaklaşımı" yaklaşımın ilkelerine göre değerlendirilmiştir. Böylece geliştirilen yaratıcı drama planının asgari şartları taşıyıp taşımadığı anlaşılmaya çalışılmıştır. Öğretmen adaylarının kendi planlarını geliştirirken bağlı kaldıkları ölçütler değerlendirildiğinde, ölçüt alınmış yaratıcı drama yaklaşımının planlama ilkelerini asgari düzeyde karşılayan planlar geliştirmiş oldukları ifade edilebilir.

Adıgüzel'in yaratıcı drama planı yapılandırma yaklaşımında, belirlenen bir kazanımın birbiriyle bağlantıları kurulmuş üç aşama içerisinde sürece dayalı ele alınması anlayışının incelenen tüm planlarda gerçekleştirildiği görülmektedir. Bu bağlamda, öğretmen adaylarının yaratıcı drama planı geliştirmeyle ilgili temel bir fikir edindikleri söylenebilir. İkinci adımda, öğretmen adaylarının hazırladıkları planlara ilişkin yaşadıkları sorunlar, ölçüt olarak belirlenen yaratıcı drama planlama yaklaşımının ilkelerine göre değerlendirilmiştir. Her ne kadar geliştirilen planlar ölçüt olarak belirlenen yaratıcı drama yapılandırma yaklaşım şablonuna biçimsel olarak uygun hazırlanmışsa da planlarda hala eksiklikler olduğu göze çarpmaktadır. Öğretmen adaylarının da ifade ettiği gibi bu eksiklikler genel olarak yaşadıkları motivasyonsuzluktan, yaratıcı drama alan bilgisi ve uygulamaların içeriğini oluşturan konulara ilişkin bilgi eksikliğinden kaynaklanmaktadır.

Çalışmanın sonuçlarından motivasyon eksikliği özellikle dikkate değerdir. Çalışmanın sonuçları göstermektedir ki yaratıcı drama süreçlerini planlamada masa başında gerçekleştirilen çalışmalar kadar planı yapanın koşullarından ve bireysel durumundan kaynaklanan motivasyonunun da önemli olduğu ortaya çıkmıştır. Çalışmada, öğretmen adaylarının yaşadıkları sorunlar ayrı ayrı kategorize edilmiş olsalar da belli noktalarda iç içe geçmekte, kesişmektedirler. Yaratıcı dramaya ve yaratıcı drama planlaması yapmak için seçilen kazanımı kapsayan konuya ilişkin bilgi eksikliğinin yapılması amaçlanan işe dönük bir yetersizlik duygusu yarattığı ifade edilebilir. Bu yetersizlik duygusunun ise öğretmen adaylarında planlamayı gerçekleştiremeyeceklerine ilişkin bir kaygıya, motivasyon eksikliğine dönüştüğü söylenebilir. Bu durum, yaratıcı drama dersinin içeriğinin bir dönemlik derste verilemeyecek kadar yoğun olmasından da kaynaklanıyor olabilir. Aslında yaratıcı dramanın temel kavramlarına, planlama ve uygulama anlayışına ayrılacak bir dönemlik dersin ardından, bir başka dönemde de yalnızca uygulamaya dönük bir drama dersinin olması öğretmen adaylarının yaratıcı dramanın alan bilgisini daha geniş bir zamanda ve derinlemesine öğrenmelerini sağlayabilir. Ancak bu çalışmada tespit edilen sorunlar yumağının önümüzdeki yıllarda öğretmen adaylarının yaratıcı dramayı planlama sürecinde de devam etmesi olası gözükmektedir.

Bunun nedenlerinden biri; önceki yıllarda eğitim fakültelerinde okulöncesi, sınıf ve sosyal bilgiler öğretmenliği programlarında zorunlu ders olarak okutulan yaratıcı dramanın, 2018 yılında öğretmenlik programlarında yapılan güncelleme (Yükseköğretim Kurulu, 2018) sonucunda sosyal bilgiler öğretmenliğinde zorunlu ders olmaktan çıkartılmasıdır. Buna ek olarak; yaratıcı dramanın zorunlu ders olarak okutulduğu programlardaki ders saatleri azaltılmış, dersin uygulama boyutu kaldırılmıştır. Oysa Yükseköğretim Kurulu (2018) tarafından "eğitimde drama" dersi için belirlenmiş kur tanımında; "yaratıcı drama ders planının hazırlanması ve uygulanması" biçiminde 
bir ifade bulunmaktadır. "Eğitimde drama" dersinin kur tanımında yer verilen "yaratıcı drama ders planının hazırlanması ve uygulanması" amacının, dersin öğretmenlik programlarındaki mevcut durumuyla gerçekleştirilemeyeceği ortadadır. Bu bağlamda, uygulama boyutu eksik bırakılmış, iki saatlik kuramsal bir derse dönüştürülmüş "eğitimde drama” dersinin etkili öğretimi olanaklı gözükmemektedir. 2018 y1lında öğretmenlik programlarında gerçekleştirilen değişikliklerin olumlu yönlerinden biri "eğitimde drama" dersine meslek bilgisi seçmeleri dersleri arasında yer verilmesidir. Böylece bütün öğretmen adayları bu dersi seçebileceklerdir. Ancak bu ders de iki saatlik kuramsal ders olarak tanımlanmıştır.

Üniversitelerdeki öğretmenlik programlarında yaratıcı drama derslerini veren öğretim elemanlarının, yaratıcı drama dersinin yeni öğretmenlik programlarındaki durumuna ilişkin görüşlerinin değerlendirildiği bir çalışmada (Metinnam, 2018) da yaratıcı drama dersinin yeni programlardaki ders saatiyle verilmesinin uygulama kısmının eksik kalmasına, yaratıcı drama yönteminin doğru biçimde uygulanamamasına neden olabileceği yönünde bulgulara ulaşılmıştır. $\mathrm{Bu}$ yüzden, yaratıcı dramanın ders saatlerinin düşürülerek uygulama boyutunun kaldırılması yaratıcı dramanın yöntem olarak kullanılmasına ilişkin sorunların çözüme ulaşacağı bir ortamdan çok sorunların daha da derinleşeceği bir öğretim sürecinin habercisi olabilir. Alanyazındaki çalışmalarda da öğretmen adaylarının yaratıcı dramayı planlayamadıklarını ve uygulayamadıklarını ifade ettikleri (Kuşdemir-Kayıran, 2018), kendilerini planlamada yetersiz gördükleri ( Özer, İlhan ve Taşkya, 2017) çalışmalara rastlanmaktadır.

$\mathrm{Bu}$ çalışma, öğretmen adaylarının planlama öz-yeterliklerini ortaya koymak gibi bir amaç gütmemektedir. Çalışmanın amacı, yalnızca öğretmen adaylarının yaratıcı drama planlama süreçlerinde yaşadıkları sorunları belirlemek ve bu sorunları öğretmen adaylarının gözünden aktarmaktır. Bu yüzden alanyazında çalışmayı destekleyecek benzer çalışmalara pek rastlanmamıştır. Sonuç olarak, öğretmen adayları yaratıcı drama planlama süreçlerinde çeşitli sorunlar yaşadıklarını ifade etmişlerdir. Bu sorunların çözümü için yeni öğretmenlik programlarında ders saati düşürülerek uygulama boyutu kaldırılan yaratıcı dramanın ders saatinin artırılarak uygulama boyutunun geri getirilmesi, öğretmen adaylarının kurmaca nitelikli sanat yapıtlarıyla (roman, öykü, sinema filmi, tiyatro vd.) daha çok buluşturularak kurmacaya ve kurguya dönük deneyimlerinin zenginleştirilmesi, eğitim fakültelerinde yaratıcı drama anabilim dalları açılarak öğretmenlik programlarında eğitim gören öğretmen adaylarına "yaratıcı drama öğretmenliği” nde yandal yapabilecekleri koşulların sağlanması önerilmektedir. 


\section{Kaynakça}

Adıgüzel, H. Ö. (2002). Eğitim bilimlerinde ve sanat eğitiminde yöntem, disiplin ve sanatsal boyutlarıyla yaratıcı drama. 11. Eğitim Bilimleri Kongresi. Yakın Doğu Üniversitesi: KKTC, 23-26 Ekim.

Adıgüzel, H. Ö. (2006). Yaratıı drama kavramı, bileşenleri ve aşamaları. Yaratıcı Drama Dergisi, 1(1), 17-29.

Adıgüzel, Ö. (2016). Bir ders ve yöntem olarak yaratıcı drama alanında yapılan çalışma ve gelişmeler. N. Aykaç (Ed.), 24. Uluslararası Eğitimde Yaratıcı Drama Kongresi "Ders Drama Yöntem Drama" kitabı içinde (s. 9-13). Muğla: Muğla Sitkı Koçman Üniversitesi.

Adıgüzel , Ö. (2018). Eğitimde yaratıcı drama. İstanbul: Yapı Kredi Yayınları.

Akdemir, H. ve Karakuş, M. (2016). Yaratıcı drama yönteminin akademik başarı üzerine etkisi: Bir meta-analiz çalışması. International Journal of Active Learning, 1(2), 55-67.

Akyel, Y. ve Çalışkan, N. (2013). Okul öncesi eğitim kurumlarında görev yapan öğretmenlerin drama yöntemi yeterliliklerinin değerlendirilmesi. Ahi Evran Üniversitesi Kırşehir Eğitim Fakültesi Dergisi, 14(3), 161173.

Batd, V. ve Batd, C. (2015). Effect of creative drama on academic achievement:A meta-analytic and thematic analysis. Educational Sciences: Theory and Practice, 15(6), 1459-1470.

Bowell, P. ve Heep, B. S. (2001). Planning process drama. London: David Fulton Publishers Ltd.

Cantürk-Günhan, B. (2016). Türkiye'de uygulanan drama temelli eğitimin matematik başarısına etkisi: Bir meta-analiz çalışması. International Online Journal of Educational Sciences, 8 (2), 145-162

Çelik, S. (2013). İlköğretim matematik derslerinde kullanılan alternatif öğretim yöntemlerinin akademik başarıya etkisi: bir meta analiz çalışması. Yayımlanmamış yüksek lisans tezi, Eskişehir Osmangazi Üniversitesi, Eskişehir.

Çelikkaya, T. ve Koç, İ. (2015). Öğretmenlerin sosyal bilgiler dersinde drama yöntemini uygulama yeterliliklerin belirlenmesi. Uluslararası Türk Eğitim Bilimleri Dergisi, 2015(4), 304-316.

Çetingöz, D. ve Cantürk-Günhan, B. (2011). Drama uygulamalarının okul öncesi eğitimi öğretmen adaylarının drama etkinlikleri planlama becerilerine yönelik görüşleri üzerindeki etkileri. Mersin Üniversitesi Eğitim Fakültesi Dergisi, 7(1), 89-99.

Çıkla, S. (2002). Romanda kurmaca ve gerçeklik. Hece Aylık Edebiyat Dergisi, 6(65/66/67), 111-129.

Fleming, M. (2003). Starting drama teaching. New York: David Fulton Publishers.

Kesici, A. E. (2014). Drama dersine ilişkin öğretmen görüşleri. Abant İzzet Baysal Üniversitesi Eğitim Fakültesi Dergisi, 14(2), 186-203.

Kuşdemir-Kayıran, B. (2018). Sınıf öğretmenliği adaylarının yaratıcı dramaya ilişkin algıları ve tutumları üzerine bir çalışma. Bursa Uludağ Üniversitesi Ĕgitim Fakültesi Dergisi, 31(2), 679-708.

Lee, B. K., Patall, E. A., Cawthon, S. W., \& Steingut, R. R. (2014). The effect of drama-based pedagogy on PreK-16 outcomes: a meta-analysis of research from 1985 to 2012. Review of Educational Research, 20(10), 1-47.

McCaslin, N. (2016). Sinıf içinde ve dışında yaratıcı drama (P. Özdemir Şimşek, Çev. Ed.). Ankara: Nobel Akademik Yayıncılık.

Merriam, S. B. (2002). Qualitative research in practice: Examples for discussion and analysis. San Francisco: Jossey-Bass.

Mesleki Yeterlilikler Kurumu (2018), 6. Seviye yaratıcı drama eğitmeni ulusal meslek standartları. Erişim adresi https://portal.myk.gov.tr/index.php?option=com_meslek_std_taslak\&view=taslak_revizyon\&tas$\mathrm{k}=$ indir\&id $=4 \&$ standart_id $=3792$

Metinnam, İ. (2018). Yeni öğretmen yetiştirme programlarında drama dersi. 13. Uluslararası Balkan Eğitim ve Bilim Kongresi. Trakya Üniversitesi: Türkiye, 6-8 Eylül 2018.

Özer, M. H. ve İlhan, E. ve Taşkaya, S. M. (2017). Sınıf öğretmenlerinin drama yöntemine ilişkin görüşlerinin incelenmesi. Uluslararası Çocuk Edebiyatı ve Eğitim Araştırmaları Dergisi, 1, 39-50. 
Şahin, A. (2017). Drama dersini alan ve almayan sınıf öğretmeni adaylarının drama tekniğiyle ilgili algılarının ve öz yeterliliklerinin karşılaştırılması. Bayburt Eğitim Fakültesi Dergisi, 12(23), 353-365.

Şahin, A. (2018). Sınıf ve Türkçe öğretmeni adaylarının drama yöntemini kullanmaya yönelik algılarının ve öz yeterlik düzeylerinin belirlenmesi. Trakya Üniversitesi Sosyal Bilimler Dergisi, 20 (1), 1-13.

Taylor, P. (2003). The drama classroom: Action, reflection, transformation. London and Newyork: RoutledgeFalmer.

Toraman, Ç. ve Ulubey, Ö. (2016). The effect of creative drama method on the attitude towards course: A meta-analysis study. Eğitim Bilimleri Araştırmaları Dergisi Uluslararası E-Dergi, 6(1), 87-115.

Toyle, N. ve Prendville, F. (2000). Drama and traditional story for the early years. Oxon: RoutledgeFalmer.

Ulubey, Ö. ve Toraman, Ç. (2015). Yaratıcı drama yönteminin akademik başarıya etkisi: Bir meta-analiz çalışmas1. Mustafa Kemal Üniversitesi Sosyal Bilimler Enstitüsü Dergisi, 12(32), 195-220.

Ulubey, Ö. (2018). The effect of creative drama as a method on skills: A meta-analysis study. Journal of Education and Training Studies, 6(4), 63-78.

Yıldırım, A. ve Şimşek, H. (2013). Sosyal bilimlerde nitel araştırma yöntemleri. Ankara: Seçkin Yayıncılık.

Yükseköğretim Kurulu (2018). Yeni öğretmen yetiştirme lisans programları. Erişim adresi https://www.yok. gov.tr/kurumsal/idari-birimler/egitim-ogretim-dairesi/yeni-ogretmen-yetistirme-lisans-programlari 


\section{Ekler}

Ek-1: "Yaratıcı Dramayı Planlama ve Yapılandırmada Adıgüzel Yaklaşımı" Örnek Yaratıcı Drama Planı Şablonu

\section{Ders:}

Konu (Tema):

Kazanımlar:

Süre:

Sınıf (Çalışılacak Grup):

Araç-Gereçler:

Yöntem ve Teknikler:

Süreç:

\section{Hazırlık-Isınma Çalışmaları}

1. Etkinlik

2. Etkinlik

II. Canlandirma

3. Etkinlik

4. Etkinlik

III. Değerlendirme-Tartışma

5. Etkinlik 



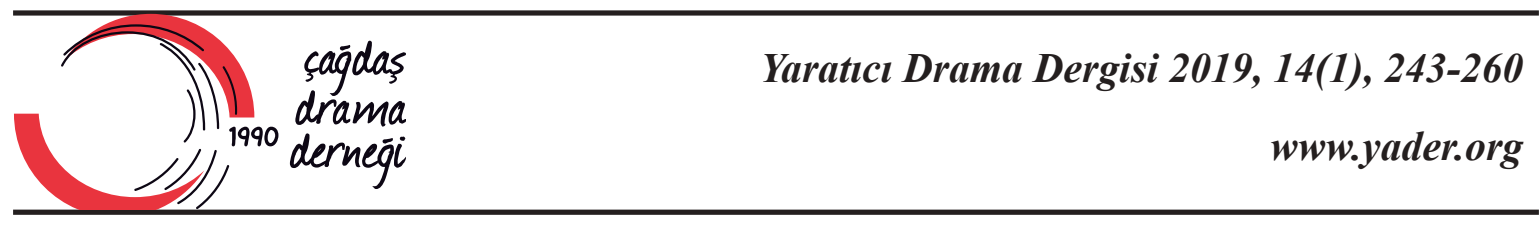

\title{
Teaching Adolescents Civil Law: Process Drama as a Tool for Achieving Legal Literacy
}

\author{
Antigone Laskarides ${ }^{1}$
}

\author{
Alkistis Kontoyianni ${ }^{2}$ \\ Asterios Tsiaras $^{3}$ \\ Christina Zoniou ${ }^{4}$
}

\begin{tabular}{|c|c|}
\hline Article Info & Abstract \\
\hline DOI: $10.21612 /$ yader.2019.014 & $\begin{array}{l}\text { Drama in Education is an experiential way of learning that can be applied in a } \\
\text { variety of ways in many learning fields. This article presents an action research that }\end{array}$ \\
\hline Article History & uses Process Drama as an alternative way of teaching Civil Law class to 16 year \\
\hline Received & old adolescents of the Vocational School of Kranidhi, Greece. Clarifying complex \\
\hline 02.07 .2019 & $\begin{array}{l}\text { legal meanings through Drama is used as a key to Legal Literacy. A pre-test, post-test } \\
\text { design with a control group has been used for the evaluation of the method. In total } 30\end{array}$ \\
\hline Keywords & students of two vocational schools took part. For the experimental group, 24 teaching \\
\hline Drama in education & hours of regular lessons were replaced with teaching using Drama in Education. For \\
\hline Process drama & the evaluation of this intervention, a valid and reliable tool was developed. In addition, \\
\hline Legal literacy & $\begin{array}{l}\text { data were also collected from interviews, participant observations and critical friend } \\
\text { observations. Results support the claim that Drama in Education leads to better }\end{array}$ \\
\hline Civil law & understanding of complex Civil Law meanings and contributes to the proposition of \\
\hline Experimental learning & Drama as an alternative way of teaching in secondary school. \\
\hline Adolescents & \\
\hline \multicolumn{2}{|l|}{ Article Type } \\
\hline Research paper & \\
\hline
\end{tabular}

1 Teacher, 1st Vocational School of Kranidi, Greece. E-mail: antigonelaskarides@gmail.com Orcid ID: https://orcid.org/0000-0002-3284-5281

2 Professor, Department of Theatre Studies, Faculty of Fine Arts, University of the Peloponnese, Greece. E-mail: alkistiseros@gmail. com. Orcid ID: https://orcid.org/0000-0003-4342-7592

3 Associate Professor, Department of Theatre Studies, Faculty of Fine Arts, University of the Peloponnese, Greece. E-mail: tsiast@hotmail.com. Orcid ID: https://orcid.org/0000-0001-6169-6433

4 Special Teaching Staff, Department of Theatre Studies, Faculty of Fine Arts, University of the Peloponnese, Greece. E-mail: czoniou@hotmail.com 


\section{Gençlere Medeni Kanunu Öğretmek: Hukuk Okuryazarlığı Eğitiminde Süreçsel Dramanın Bir Araç Olarak Kullanımı}

\begin{tabular}{|c|c|}
\hline \multirow{2}{*}{$\begin{array}{l}\text { Makale Bilgisi } \\
\text { DOI: } 10.21612 / \text { yader.2019.014 }\end{array}$} & \multirow{3}{*}{$\begin{array}{l}\text { Öz } \\
\text { Ĕgitimde dramanın kullanılması öğrenmenin birçok şekline uygulanabilecek } \\
\text { deneysel bir öğrenme yoludur. Bu makale, Yunanistan'da bulunan Kranidhi Meslek } \\
\text { Okulu'nda eğitim gören } 16 \text { yaşındaki gençlere Medeni Kanunu süreçsel drama }\end{array}$} \\
\hline & \\
\hline Makale Geçmişi & \\
\hline Geliş tarihi & kullanarak alternatif bir şekilde ögretmeyi kapsayan bir eylem araştırmasını içerir. \\
\hline 02.07.2019 & Karmaşık hukuk anlamlarının drama ile açıklanması hukuk okuryazarlı̆̆ına giden \\
\hline Anahtar Sözcükler & $\begin{array}{l}\text { yolda çok önemlidir. Yöntemin değerlendirilmesi için kontrol grubunda ön test- son } \\
\text { test kullanılmıştır. Kontrol grubunda iki meslek okulundan toplamda } 30 \text { öğrenci }\end{array}$ \\
\hline Eğitimde drama & bulunmaktadır. Deney grubunda ise 24 saatlik normal dersler eğitimde drama yöntemi \\
\hline Süreçsel drama & ile işlenmiştir. Ayrıca, veriler görüşme, katılımcı gözlem ve akran gözlem metotları \\
\hline Hukuk okuryazarlı̆̆l & ile toplanmıştır. Sonuçlar, eğitimde drama yönteminin karmaşık Medeni Hukuk \\
\hline Medeni Kanun & terimlerinin anlaşılmasını kolaylaştırdı̆̆ \\
\hline Deneysel ögrenme & alternatif bir yöntem olarak kullanılması önermesine katkıda bulunur niteliktedir. \\
\hline Gençler & \\
\hline Makale Türü & \\
\hline Araştırma Makalesi & \\
\hline
\end{tabular}




\section{Introduction}

Law can be defined as a system that regulates behavior aiming to achieve social peace and coexistence. Even if people familiarize with rules from the very beginning of our lives, legal system can be so complex that directly determines as "privileged" those who are well aware of its mechanisms, or those who can afford regular access to legal advice and services.

Definition of "Literacy" in general, stands between fundamental human rights, even as a tool for better health treatment, income and fully participation of the person in community and wider society (UNESCO, 2017, p. 14-15). Legal literacy though, is defined as:

"a more complex concept that includes the ability to navigate a legal process with understanding, recognize a legal right or responsibility and recognize when problems or conflicts are of a legal nature" (UNESCO, 2017, p. 15).

However it is clear that understanding fundamental principles of the legal system can be considered as a very basic knowledge, to be introduced yet from school years, it seems mainly to be infused into various standard courses of the curriculum (Pereira, 1988: 4) in most countries. It is though important to clarify that this article refers both in law and educational system as it is established in Greece.

Civil Law as a fundamental branch of Private Law deals almost with all acts of individuals (OECD, 2012, p.12), and also with acts of the state and its bodies in case of acting as individuals. It was the first law branch developed in modern Greece, and serves as a primary source of law, as it is consisted of codified core principles. Civil Law is a social construct highly connected with ethics and etiquette that aims to social peace and coexistence (Varka-Adami, \&Karanasios, 2016, p.15).

"General principles" is the first book of the Greek Civil Code. Legal terms contained in this book are considered the foundation of Law in Greece (Georgiades, 2010:1). Meanings like "Distinction between Law and Ethics", "Grammatical or Logical Interpretation of Law", "Definition of Rights (claim and abuse)", "Subject to Legal Action (natural or legal person)" and "Validity of a legal Act" clarified in "General Principles" are used or combined to form most of the rules of law (Georgiades, 2010, p.1). Therefore the degree of their perception can be used as a legal literacy "barometer".

Though above terms can sound complex, people who aren't aware of the way the legal system works can be alienated and in danger of committing infringements. Most of all they may have limited access to justice. (Zariski, 2011, p.19).

This article emphasizes the need of starting legal education even from high school, where sensitivities and major interests are formed (Zanouzani Azad, 2012, p.19).

\section{Legal Literacy in the Greek Curriculum}

Speaking of the general education Greek curriculum, some of the legal meanings are infused in the course of "Civil Education". It is a class of two hours per week at the second grade of senior high school, containing legal meanings in two out of ten chapters of the schoolbook (Law 4186, Official Government Gazette 193/IssueA'/17-9-2013).

On the other hand, in Vocational schools, law meanings are included in the curriculum of the second grade sector "Management and Economy", where, under the title "Elements of Law", is 
taught a law-targeted class of four hours per week (Law 4386/ Official Government Gazette 1567/ IssueB'/2-6-2016).

In Vocational schools, students of the Management and Economy sector are prepared for a "fast entry" in practical application of rules of law. Therefore the teacher has the opportunity to present the General Principles of Civil Law, using many examples of everyday life and simulating the UNESCO definition for Legal literacy (UNESCO, 2017, p. 15).

\section{Drama in Education as a Tool for Experiential Learning}

Presence of Drama in Education exceeds its artistic dimension. It can be a field where a variety of methodological approaches, tools and techniques can be used by the teacher as learning mediums (Avdi, \& Chatzigeorgiou, 2007, p. 20).

Through the natural process where make-believe play serves learning, Drama in Education uses body movement, rhythm, speech, sound, role-play within the educational environment, giving participants new perspectives through familiar techniques, making understandable the complex world we live (Kosti, 2016, p.78).

The contribution of Drama in experiential learning consists in a complex procedure of both theory and application, action and reflection (Alkistis, 2008, p. 165). Participants live the experience building an imaginary world, still keeping views of the real (Avdi \& Chatzigeorgiou, 2007, p.42). Theatrical elements like: role playing, dramatic tense, focus, place, time, language, movement, atmosphere, symbol and dramatic meaning are claimed to create this imaginary world (O'Toole, 1992, p.13-46).

Process drama is almost identified as Drama in Education. However Process Drama arises in the 80 's as an attempt to define a more structured dramatic form from less complex theatrical techniques used in education(Taylor, \&Warner, 2006, p.3). It seems more focused in creating a series of episodes (Fransen, 2003, p.8) that are not necessarily linear (Taylor, \&Warner, 2006, p.3). Mostly is a way of focusing in different point of views of the objective. The teacher, who is often participating in Drama, is leading the point of view.

Cecily O' Neill, who was inspired by Dorothy's Heathcote famous work, gives the definition in her book under the title "Drama Worlds, A Framework for Process Drama” (O’Neil, 1995, p.xiii):

"Process drama is a complex dramatic encounter. Like other theatre events, it evokes an immediate dramatic world bounded in space and time, a world that depends on the consensus of all those present for its existence. Process drama proceeds without a script, its outcome is unpredictable, it lacks a separate audience and the experience is impossible to replicate exactly".

\section{Process Drama for Conducting Action Research}

According to Reason \& Bradbury (Reason \& Bradbury, 2008, p.1):

"Action research is a family of practices of living inquiry, that aims, in a great variety of ways, to link practice and ideas in the service of human flourishing. It is not so much a methodology as an orientation to inquiry that seeks to create participative communities of inquiry in which quality of engagement, curiosity and question posing are brought to bear on significant practical issues" 
Process Drama, focusing in different point of views of the objective, seems to empower action research processes (Tofteng et al., 2011) giving the researcher the opportunity both to intervene and to conduct his study. It seems that, in a way, Process Drama interventions for research reasons concur with action research while in both cases learning is produced by the participants (Athanasiou, 2007, p.330).

\section{Literature Review}

Literature on the teaching of law mainly approaches students of higher education. While educational methods used in Law Schools are highly related to theatrical techniques (Friedland, 1996 ,p.27), the main target is familiarization with the role of the lawyer and legal speech (Stuckey, 2007, p.121), and much less with experiential understanding of parts involved. Even less they intend to clarify the logical reasoning of the legislator.

Under this angle, many experiential workshops with role-playing are presented in Roy Stuckey's (Stuckey, 2007) book, "Best Practices for Legal Education".

As more specified research for using Drama in legal education is the one of Scully-Hill et al. (Scully-Hill et al., 2010) "Beyond Role Playing: Using Drama in Legal Education". It is both an empirical and bibliographical research in Hong Kong University that reveals the benefits of theatrical acts of law students (that took place for non-educational purpose), in understanding all points of view of the legal system.

For teenagers, law teaching methods are pretty poor, while a research concerning the use of Drama for teaching adolescents the law couldn't be traced.

Research tools for data collection upon the legal literacy of adolescents are developed in two levels: In countries with great illiteracy rate research is focused on the knowledge of governmental or religious power limits while in western countries it is focused on the knowledge of rights upon a certain subject (i.e. bullying).

Among above research using questionnaires as research tools, the most relevant to general law knowledge of adolescents is the one that took place in England and Wales on behalf of the Legal Services Board and the Law Society in 2015. The research concerns mainly adults, but a part of it is designed for teenagers (IpsosMORI, 2016, p. 129) aiming to find the source of their legal information and consulting. Again here, data collection for understanding fundamental legal meanings, is not present.

All above support the development of a new research tool adjusted to study the level of Legal Literacy of teenagers.

\section{Research Limitations}

The most obvious limitation of this research is the small sample size. Number of participants was finalized after pre-test. In addition one participant never completed the post-test questionnaire. This fact prevents a clear generalized statement about the impact of the teaching method.

Occasionally, absence of students was substituted by reflective discussion in the next intervention. This, of course, cannot prevent learning gaps. 
One of the interventions (the eleventh) was not properly completed. School finished one hour earlier due to a bus change of schedule and the intervention was limited in narration and reflective discussion.

Critical friend could not be physically present during the interventions as planned. This led in video-taping the lessons with the consent of participants. It is possible that the presence of a camera in the room affected the freedom of expressions of the participants. Additionally, the perception of the drama atmosphere is difficult to be recorded on camera.

On behalf of the teacher, the use of Drama proved to be demanding and required persistence. All lessons plans were designed from scratch. Process Drama requires fantasy, alertness and adjustability to the team of participants. Sometimes preparing a lesson needed many hours of preparations, while teaching time proved to be energy consuming.

\section{Research Method}

Objective of the research was to teach Civil Law using process drama in a Greek vocational school and compare results linked to Legal literacy with the traditional way of lecture-based learning.

Fundamental legal meanings contained in General Principles of Civil Law were selected on the basis of their relevance with the school curriculum goals (Official Government Gazette 1561/ issueB'/17-8-2007), for the course "Law Elements". Selected meanings are: "Distinction between Law and Ethics", "Grammatical or Logical Interpretation of Law", "Definition of Rights (claim and abuse)", "Subject to Legal Action (natural or legal person)" and "Validity of a legal Act".

Five research questions were focusing on whether each one of those terms were better perceived and understood by adolescents, when teached with Drama techniques.

Twelve two-hour classes of traditional lecture-based teaching were replaced with twelve workshops-interventions, using Drama in Education. The effectiveness of the intervention was evaluated with pre-test, post-test and control group.

Two groups of students of the Economy and Management sector of Vocational schools were selected using convenience sampling. Both groups were pre-tested, while first group (experimental) was affected by the independent variable (Drama in Education). Level of results was measured after the intervention for both groups in order to study possible differentiation between two groups. Experimental group was consisted of 15 students of Kranidhi Vocational school (11 girls and 4 boys), while control group was consisted of 15 students of Nafplion Vocational school (3 girls and 12 boys).

\section{Data Collection Tool Development}

Effectiveness of the intervention was measured for both groups using a questionnaire of quantitative research, developed with closed questions of Lickert type (Anderson et al., 1983: 253) focused on the level of understanding law meanings.

Items were divided into five factors (five research questions). The questionnaire was evaluated for item clarity and completion time (by a small pilot survey), content validity (content validity ratio $>0,99$ ) by 3 law professionals and 3 teachers (Berk, 1990: 659) and for its reliability (Cronbach's alpha $>0,7$ for each factor) by a second pilot survey. Data were processed by the SPSS 
(Statistical Package for Social Sciences) software. Final questionnaire was formed to 31 questions and completion time 20-25 minutes and value of Cronbach's alpha 0,741

\section{Data Collection Process}

Both the experimental and the control group were pre-tested before and post-tested after the interventions, using the research tool, in order to study possible quantitative differentiation between two groups.

After pre-test results, standard deviation was calculated $\mathrm{s}=11,7$ for the experimental group and $\mathrm{s}=18,17$ for the control group. Confidence interval was selected to be $95 \%$.

At the same time qualitative research tools were also used in order to confirm results of the quantitative data: interviews of the students, participant observation diary and the presence of a critical friend.

\section{Short Description of the Interventions}

Twelve lesson plans were developed emphasizing experiential learning through Drama in Education, mainly through Process Drama. A classroom that was out of use was emptied, well cleaned, wall decorated and carpeted. Students were welcomed in an empty room with discrete music and air-freshener scent. Each two-hour class was replacing two hours of traditional lecturebased teaching with Process Drama for the experimental group, while the same teaching time for the control group was taking place traditionally in the classroom.

Interventions were divided in five main topics related to the five legal meanings forming the research questions. Sub-topics were also formed in most cases, consuming more than one intervention. Each two-hour class was devoted to one sub-topic. Topics, sub-topics and interventions are shortly described below.

All interventions were starting with a specially designed warm-up game, relevant to the topic. Neelands and Goode techniques (Neelands, \&Goode, 2015) either variants or the same, were used for building a story in episodes. Episodes were connected with narration. Each story was a well understood practical example of the topic studied, sometimes providing a moral dilemma, while many were based on true stories. Participants were mostly embodying collective roles, enlightening different points of view to the story, while dramatic action was conducted by the teacher. The pattern beginning - climax - end was developed for each of the stories. After the end of the story, a reflective discussion was necessary to summarize the experience (Alkistis, 2008: 165).

\section{Distinction Between Law and Ethics}

Even if ethics affects rules of law, there is no absolute identification of law and ethics (VarkaAdami \& Karanasios, 2016:16). It is often acceptable not to accord rules of law and show loose morality (i.e. avoid taxation), while immoral acts don't seem to violate law (i.e. indifference for our neighbor). And in first case penalties are suggested, while in the second case the result may be only social disapproval or sense of guilt. This basic difference is crucial for setting the operational limits of the legal system. (Varka-Adami \& Karanasios, 2016: 16). 


\section{"I have no scepter, but I have a pen"}

A Process Drama was planned upon the true story of the 17 year old first king of newer Greece, Otto. The young king had to legislate from scratch upon citizen's requests (teacher-in-role) with the help of his trusted advisors (collective role). This concept was leading the participants-in role of advisors both to legislate and to organize legal rules.

The main goal was to clarify that legal system is a man-made construct highly connected with ethics and etiquette, but not absolutely identical to them.

\section{Grammatical or Logical Interpretation of Law}

Sometimes law texts are composed in a way that creates discussions concerning the meaning and the scope of application (Varka-Adami \& Karanasios, 2016: 24). Interpreting the meaning of a legal text is a matter of scientific study and can lead to word correction of the text. Therefore the importance of understanding the difference between "letter and spirit of law" and the fact that each legal text raises a logical reasoning of the legislator, may work both as a tool of legislation and as a tool of claiming justice in courts.

\section{"Standing on expectations"}

The concept of a strange family living together in a big house, under democratic rules was the main idea of the Process Drama. Father had to leave for a few days, leaving written instructions for everyone in the family (collective roles of wife, children, brother, grandparents). In some occasions, it was useless to follow those rules (i.e. wash the car under heavy rain). Participants had to decide and justify why they would follow or not written instructions.

Drama was emphasizing the clear division between the letter and the spirit of a rule. During the reflective discussion the story was brought to legal texts and their interpretation grammatically or logically.

\section{Definition of Rights (claim and abuse)}

Meaning of right is not clearly defined in Civil Law. However it is admitted as a power of individuals to satisfy and protect their interests (Varka-Adami \& Karanasios, 2016, p.29). On the other hand, it is well defined and clearly limited the meaning of abuse of rights. Article 281 of the Greek Civil Code provides that:

'the exercise of a right is prohibited where it manifestly exceeds the bounds of good faith, morality or the economic or social purpose of that right".

All above are delicate legal terms. Good faith is connected with honesty and fairness required from people that live in the same society. Morality reflects the way of thinking of a human community. Economic or social purpose of the right supports the satisfaction of the interest of a community that should prevail over the satisfaction of interest of an individual.

Even if it seems difficult for non experts to perceive, these terms are present in the routine of everyday transactions and necessary to know in order to equally participate in citizenship. In addition to all that, claiming of rights is a matter of legal processes (and not physical force). Well defined limits of our rights makes also clear when it is admitted (or not admitted) to take law in our hands (Article $282 \& 283$ of the Greek Civil Code). 


\section{"Small fisherman - big fisherman"}

As an example to the economic or social purpose of the rights it was invented the story of a fishermen village. The word was spread thata fisherman spent his lifetime savings to buy a big fishing boat with trawl nets. Trawl nets give great profit but can be destructive to the sea environment. Participants in role of villagers had to decide whether their colleague (teacher in role) was exceeding the bound of his right to use his savings the way he wanted.

\section{"Is it my right? I don't think so!"}

The concept of sexual harassment in the workplace was a spicy example concerning morality while exercising a right. It is a right of an employer to choose his employee, but can it be his right to fire a woman because she rejected a date proposal? The employee claimed back her job and participants in role of lawyers had to decide whether they wanted to defend the employer (teacher in role, using a puppet).

\section{“Are we friends or not?"}

The well known case of the popular American series "Friends" was used as a context for clarifying the meanings of good faith. Participants in role of actors signed to participate in a series for the local tv market and got paid. The scenario was smart and the series became a world success. The producer made profit beyond expectations. Actors claimed to re-arrange their payment, but the producer kept his rights upon the initial contract. Participants had to make arguments for both sides and decide whether the right of the producer to keep the initial contract was exceeding the bound of good faith.

\section{"Dynamic beauty"}

The admission (or not admission) of taking the law into our hands was attempted to be clarified with the invented story of a mysterious old woman who recently died. Participants in role of children of the neighborhood discovered in her garden's house a box with souvenirs of her life. The old woman proved to be an ex-miss Greece with a hot-tempered personality. Pieces of newspaper revealed that four times in her life took the law into her hands. Three of them she was punished and one she was awarded. Completing a life-puzzle the participants should find out the consequences of her initiative.

\section{Subject to Legal Action (natural or legal person)}

Whether we speak about natural or legal persons it is important to know when ability for legal action begins and when it ends. However in legal persons this is defined in a written statute, for natural person it is not as clear as it seems. Questions like when an individual begins to have legal rights, or what happens legally when a person is missing, are of everyone's concern. And even if it is not possible to know all relative legislation, it is important to understand the logical reasoning of the legislator.

\section{"Love for Maria"}

The beginning of existence for a natural person in law terms is a complicated mater that should exceed any philosophical questions or religious beliefs. According to the Article 36 of the Greek Civil Code, the existence of a natural person begins with conception under the condition that is born alive. If not, it never existed. 
Process Drama used an invented story, inspired by the story of the famous soprano Maria Callas. Maria is pregnant from a famous married millionaire. Even this is a big scandal and a headache for the millionaire and his wife, the millionaire is proved to be very sick. And a few months later he dies, before the birth of his child. Can Maria claim (on behalf of her baby) a part in his will? Maria's friends (collective role of participants) have to counsel her in every step of the way.

\section{"Andrew is disappeared"}

The end of the existence for a missing person is a matter of court decision and is the only way to deal with practical matters like heritage or end of marriage. The invented story of the Process Drama was inspired by a true story in the local community. Andrew, a young seaman recently married, was travelling from Mexico to Europe. On board he was disappeared and never found. His family had to deal both with mourning and with practical issues. Participants in collective family roles have to deal with the decision of legally ending Andrew's existence.

\section{Validity of a Legal Act}

Our social life contains everyday legal acts like buying and selling, rentals, loans, contracts etc. Their validity protects our interests. Civil Code defines four conditions (beside our will) in order to have a valid legal act. One is the capacity of a person for legal actions (i.e. underage persons have limited capacity for legal actions and gradually from birth till adulthood this capacity extends). (Varka-Adami \& Karanasios, 2016: 60). Next is the accordance between declaration and will (i.e. it is not valid a legal act if one part did not understand its meanings or was fooled or even was joking). Third is the adherence to a certain form which is not the same for all legal acts. In some cases an oral agreement is enough, while in other cases a notarial deed is needed (Varka-Adami \& Karanasios, 2016: 63). Finally a legal act should not contain immoral or illegal content (VarkaAdami \& Karanasios, 2016: 64) (i.e. no deal is valid if binds human freedom, like change of religious beliefs for money).

\section{“Indecent proposal”}

For clarifying the immoral content of a legal act, the context or the Process Drama was presenting a story very similar to the famous movie "indecent proposal". Diana is a married young woman. An old friend, who is obsessed with her since childhood, offers a great amount of money in order to spend a night with her. Participants in role of family friends cannot affect the couple's decision. But they can criticize afterwards the validity of the contract, when the old friend denies paying the amount agreed.

\section{"Popi's signature"}

The invented story of an old woman named Popi, was aiming to clarify when a person is capable for legal actions, and what happens if he is not. Popi dies and her children discover that she left her house to her housekeeper grateful for her care. A sly lawyer (teacher in role) suggests to her children to claim in court that Popi had lost her mind and that her will is not valid. An imaginary trial is set with participants in different roles: friends, family, housekeeper, lawyers and court.

\section{"The contract template that was bought at a kiosk"}

The adherence to a certain form is one of the conditions in order to have a valid legal act. Process Drama was dealing with a young man who recently left his parent's house and rent a small 
apartment, making a simple contract with the owner. Taking for granted that this is the only way to deal, made again a simple contract, this time to transfer real estate. Participants in role of the young man had to deal with the consequences and think of the reasons that different forms are needed in different legal acts.

\section{“Meteorite from Santorini"}

Theofilos, a collector of rare objects, was the main character of the Process Drama. He is persuaded that the small statue he bought in the market was made of meteorite stone. After an expert (teacher in role) examined the object, it proved to be made of volcanic lava. Theofilos asked for his money back, proving his claim with the description on the invoice: "Statue made of meteorite stone". Participants in roles of the shop-owner, of Theofilos and of his consulting friend had to deal with a case of discordance between declaration and will.

\section{Results}

After the completion of the interventions, the participants of the experimental and the control group completed the post-test questionnaire. Personal interviews of the participants and the critical friend took place within the following month. SPSS 20.0 (StatisticalPackageforSocialSciences) software was used to analyze quantitative data. Student's T-test was used to compare values of the means from the two groups and examine if their difference is statistically significant. Qualitative data were organized in groups in accordance to research questions.

\section{Reliability of Research Tool}

Questionnaire was checked again for reliability in pre and post-test to both groups with Cronbah's alpha value $>0,7$ for each factorand in total (Table 1).

\section{Table 1}

\begin{tabular}{|l|l|l|}
\hline Group & Pre-test & Post-test \\
\hline Experimental & 0,791 & 0,772 \\
\hline Control & 0,818 & 0,712 \\
\hline
\end{tabular}

\section{Normality Test}

Both groups (sample $\mathrm{n}<50$ ) were tested for normality using the Shapiro-Wilk test (Singh, 2007:100) and was found $>5 \%$ (since confidence level was defined $95 \%, 5 \%$ is the limit for determining that null hypothesis $\mathrm{H}_{0}$ is reasonable), indicating that our sample is normally distributed.

\section{Null Hypothesis Definition}

Null hypothesis $\left(\mathrm{H}_{0}\right)$ is that there is no significant difference in the effectiveness of teaching adolescents using Drama in Education compared totraditional teaching in understanding complex Civil Law meanings.

Alternative Hypothesis $\left(\mathrm{H}_{1}\right)$ is that there is significant difference in the effectiveness of teaching adolescents using Drama in Education compared to traditional teaching, in understanding complex Civil Law meanings. Level of significance is defined $5 \%$. 


\section{Compare Means and Standard Deviation (pre-test)}

T-test was used in order to compare means between experimental and control group and compute the standard deviation, before the interventions. Mean value was 85,38 for the experimental group and 79,21 for the control group. Levene's test was used to check the equality of variances, a condition necessary for applying parametric tests (Singh, 2007:102). Value of $p=0,135(p>0,05)$ indicates equality of variances for the two groups.

Running t-test estimatesp $>0,05(\mathrm{p}=0,300), \mathrm{t}=1,059, \mathrm{df}=25$. These values indicate that before interventions, differences between two groups are not statistically significant in terms of legal literacy measured by our questionnaire.

Standard deviation for both groups was also estimated $\mathrm{s}=10,90$ for the experimental group and $\mathrm{s}=18,18$ for the control group.

\section{Compare Means and Standard Deviation (post-test)}

After interventions mean value was measured 105,69 for the experimental group and 86,71 for the control group. Levene's test indicates again equality of variances for the two groups $(p=0,916)$.

Running t-testestimatesp $<1 \%$. Even if preliminary, this is an indication of statistically significant difference between means.

Standard deviation was estimated $\mathrm{s}=10,27$ for the experimental group and $\mathrm{s}=11,17$ for the control group.

\section{Running t-test- Estimation of the p-value.}

Independent t-test determines whether there is a statistically significant difference between two samples. Dependent variable (legal literacy) is common for the two groups with no overlapping between participants. In our case, we are interested in improvement and not just difference of the experimental group. Therefore t-test is conducted one-tailed, towards positive direction (Emvalotis, Katsis, \& Sideridis, 2006:60).

SPSS software cannot run one-tail test. This is why $\mathrm{p}$ is calculated as half of the p-value estimated by two-tailed test (Emvalotis, Katsis, \& Sideridis, 2006:60).

Results indicate increased means for the experimental group in all factors, except "subject to legal action" where improvement is almost the same for both groups. P-value varies per factor. Data of all factors, summarized under the mean of "Legal literacy" show a statistically significant improvement for experimental group from pre to post-test (Table 5), as $\mathrm{p}$-value is estimated $\mathrm{p}=0,007$ $(\mathrm{p}=0,013$ for two tailed test). Means of both groups during pre-test may indicate quite same level of knowledge, while post-test show a positive differentiation for the experimental group (Diagram 1).

Table 5. Legal literacy T-Test

\begin{tabular}{llllll}
\hline Group Statistics & & & & & \\
\hline & GROUP & $\mathrm{N}$ & Mean & Std. Deviation & Std. Error Mean \\
\hline Difference & Kranidhi & 13 & 20,3077 & 10,01153 & 2,77670 \\
\cline { 2 - 6 } & Nafplio & 14 & 7,5000 & 14,19507 & 3,79379 \\
\hline
\end{tabular}




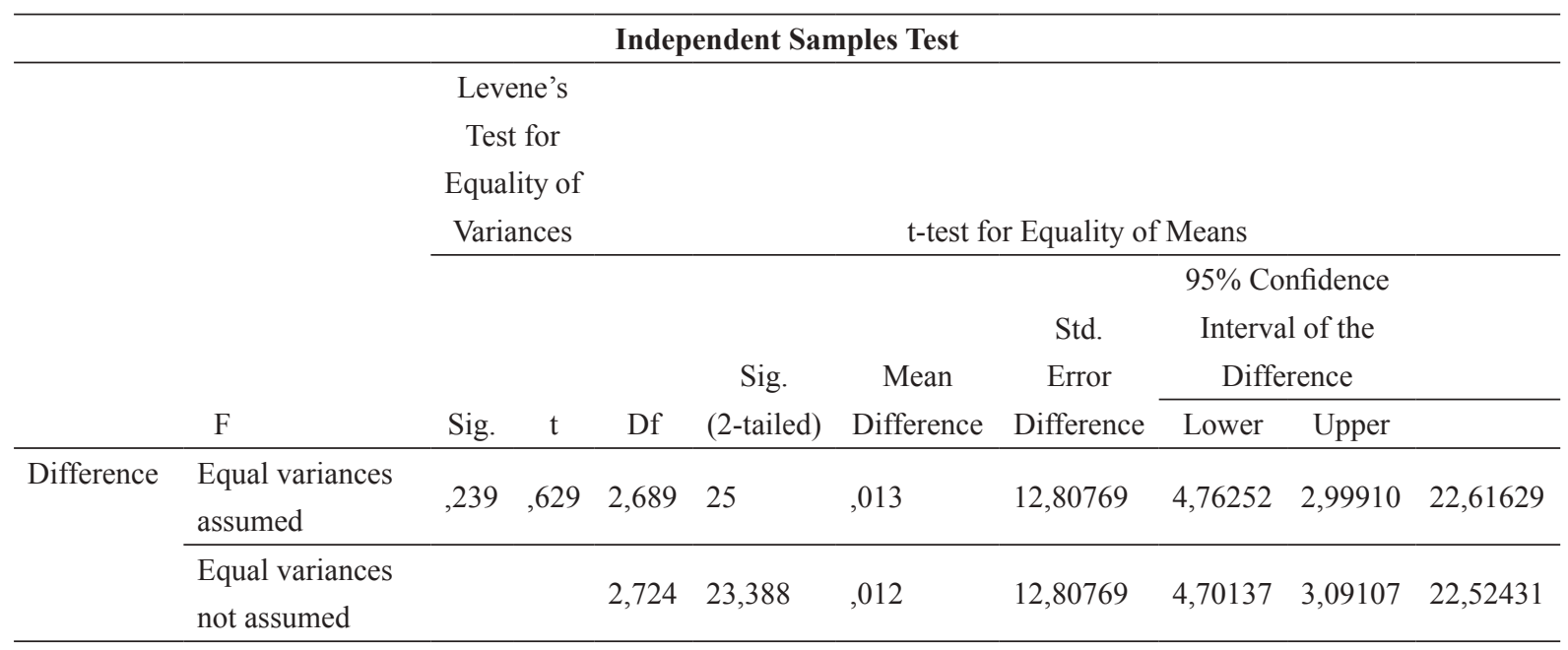

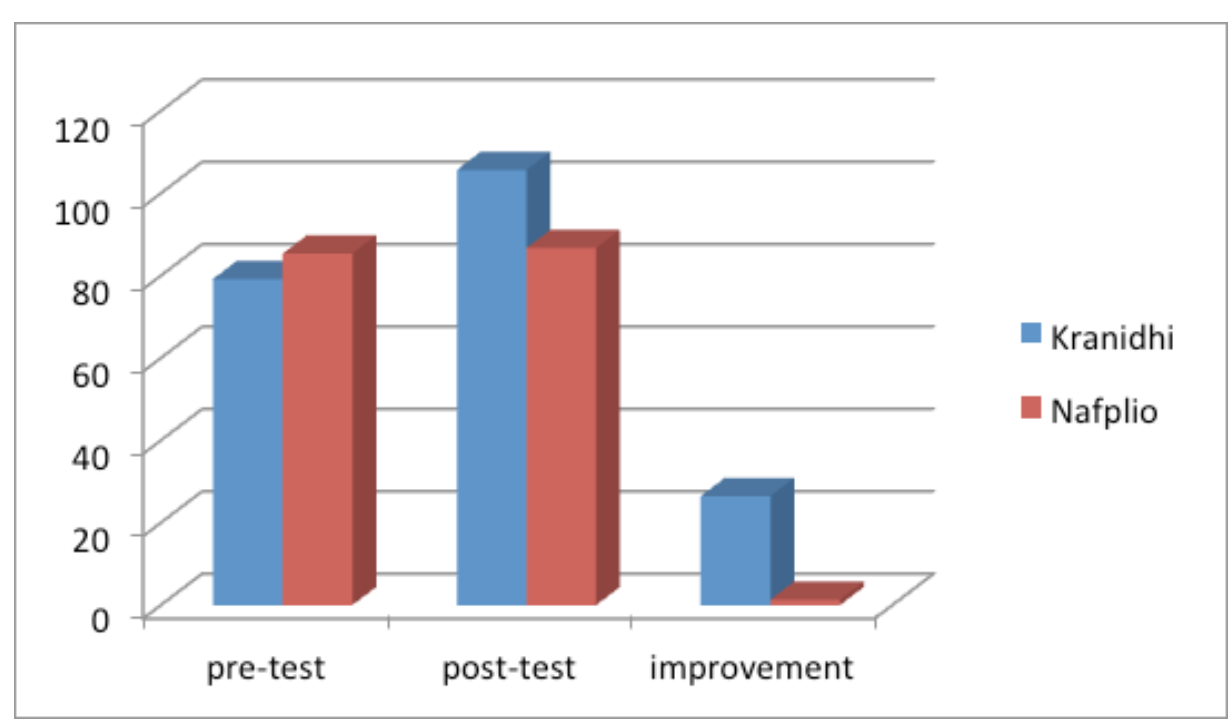

Diagram 1. Legal Literacy (means in total)

\section{Qualitative data}

During, but mostly after interventions, the teacher kept an observation diary with general and special notes both for discussion and for improvement of the following lesson plans. The physical presence of a critical friend was not achieved. However, all interventions were videotaped with the consent of participants and commented-evaluated by an experienced colleague of the same school (Swaffield \& MacBeath 2005: 250). Interviews of the participants took place two weeks after the last intervention.

Qualitative data were organized into three main groups: student's response in legal literacy, learning outcome, effect of the teaching method in other fields of learning (like team building or finding new skills) that can also count for the perception of legal literacy.

\section{Response in Legal Literacy}

Positive response is necessary for adolescents to accept familiarizing with difficult legal terms. The new teaching method was clearly noted as a "good change" for the $100 \%$ of the participants 
while 70\% experienced freedom of expression. Justification for "good change" came with more qualitative data, while a great percentage connected this belief with experiencing a sense of freedom. It seemed that even the fact that the environment was different than typical classroom was perceived positively by the participants. Interviews showed that:

"It was not a classroom with desks. We were more free"

"We could talk to each other and play without being suspended"

"It was not a regular lesson. We were playing games, we had a team spirit. The best moments in classroom".

"I liked that we were playing roles"

"It was not a boring lesson"

"Time was passing pleasantly and creatively".

"It was better because we were working all together. I was hoping not to end".

When a student was asked to mention disadvantages or problems, he joked:

"Problem is regular class".

Observation diary clearly indicates that both participants and the teacher were gradually familiarized with the new teaching method. Hesitation was quickly reversed to eagerness after the third intervention. The classroom adopted for Drama interventions was called before "the dungeon". At some point the word "dungeon" gained positive meaning as a synonym to the new teaching method. Near the twelfth intervention, students were expressing privileged for having the chance to spend time in the "dungeon". This sense of privilege was often expressed outside the classroom and noted by the teacher.

"Thank God we're going to the dungeon".

"Why don't you take us too in the dungeon? Why only them?"

"Are you crazy? Tomorrow we go to the dungeon. I don't want to miss it!"

It is also admitted that students that showed difficulties in adjustment in regular class, were also difficult to adjust in Drama procedure. Making noise, drawing attention, and unwilling to participate was almost a routine. However they were the most eager to go to the "dungeon" and they showed remarkable improvement in perception.Critical's friend notes confirmed both the gradual adjustment and the difficulties of certain students. Additionally critical friend observed that noise was directed and related to the teaching subject and was not distraction.

\section{Learning}

In all teaching subjects learning is an objective tested with written exams. As far as Legal Literacy is concerned we may say it is more than that. Learning value has to do mostly with understanding the law-logic relation than just remembering rules. Understanding of this logic is crucial for being usable in the future when needed (Zariski, 2011:19).

Interviews justified the results of quantitative analysis in terms of learning results. Students claim to have better understand $(84,62 \%)$ legal meanings, while the majority claims to remember most of what he learned $(92,31 \%)$. 
Some of the answers were:

"It was easier to understand from the examples"

"It was sticking to the mind like a game"

"We were participating in the stories and we could remember afterwards"

"We had to combine theory and action. It was easier because we were living the story and we didn't have to study it".

Better perception was also noted in the observation diary. Discussion between students reveals they were directed towards logical reasoning. One of many such examples noted in the diary, is the following dialogue:

M: "Why is Costa's fault if his neighbor was ill and died out of negligence? Was he responsible for him?"

Teacher: "Could he be responsible in some case?"

L: "If his child was dead, yes he should have been punished. What about now?"

Teacher: "Why he should have been punished then?"

L: "It was his responsibility".

Teacher: "Ok then. Can we compose the text of the law?"

M: "Red (big) penalty in case of death out of negligence of people that we are responsible of."

G: "It's not right. He should have informed the authorities for his neighbor. He should be punished for not informing”.

L: "Yes. But with a yellow (medium) penalty".

M: "I don't agree. He is not responsible for his neighbor. He may not even know he was ill. I vote for no penalty". At the end of the intervention, students edited a paragraph very similar to the reasonable logic of today's legislation:

"In case of death of negligence of a person under our responsibility we get a red penalty. In other case, should be examined if there was a way to help (yellow penalty) and if not we get no penalty"

Qualitative data confirm the statistically significant improvement of the experimental group in quantitative research concerning the level of Legal literacy. Evaluation test for the semester showed a high mean in grades (16/20) while all participants, according to the teacher council, constituted a bonded team. Teacher council and critical friend also noted that this improvement appears only in Civil Law class and not in other teaching subjects.

\section{Effect in Other Fields of Learning}

Qualitative data were also indicating affection in other fieldslike team bonding or finding new skills or even better concentration. A $76,92 \%$ noted that after interventions could work better in team. A 38,46\% discovered new skills and a 23,08\% noted improvement in concentration.

Team working is important in all learning process as a way to concentrate different resources from different participants to a capital disposable to all team members (Barkley, Cross\&Major, 2005: 22). Interviews showed better collaboration between members of the group. 
"Team bonding games were helpful in solving problems"

"I can do better if we work as a team"

"Sometimes it was difficult to decide. Many opinions were heard. At that point I think it was easier to decide".

Negative comments were also focusing in difficulties of collaboration between participants. A $30,77 \%$ seemed to be disturbed from those who denied to participate while a $46,15 \%$ felt bothered from participants that were joking, spoiling drama atmosphere. The bonding achieved seems that led into other objectives too, like team working for funding the annual excursion.

Finding new skills is another field affected by the use of Drama. Even if it is not directly related to Legal Literacy, finding new skills seems to be connected with self confidence (Bunker, 1991: 469). Claim of rights is a necessary component in citizenship. Many legal rules are produced by citizen's claims. Self confidence is a way to activate claiming. To the question whether they found something new about themselves, some students answered:

"I discovered that it was not so awkward to draw attention".

"Now I can stand them easier (my colleagues)".

"I found out I could say my opinion even if I disagree with the others".

"I liked the role playing. I think I would like to play theater".

"Before dungeon, I was ashamed of my voice. Now I like the way I talk".

Finding new skills was also mentioned in the observation diary. Some of the participants became members of the theatrical team that year ( 3 students), some presented a documentary film (4 students), some participated in scenery and puppet construction (7 students).

Self concentration was also noted in some students' interviews. Lack of self concentration needs special learning treatment. Observation diary does not contain this element. However an important note of the critical friend is related. Sometimes action seemed to stop and discussions seemed to skip basic rules of civilized dialogue. Teacher was making remarks to bringing the class back to order. Critical friend noted that most of the noise was expressing passionate defending of the right which is a healthy and desirable reaction.

\section{Discussion}

Small sample size of the research prevents any generalized statement beyond the context of this study. Howeverthe findings in this limited context were clearly positive. What is already reported in existing literature -that the use of Drama can be used by the teacher as a tool for experiential learning (Avdi, \&Chatzigeorgiou, 2007, p. 20) is justified by this research with very good results.

Applying process Drama for the understanding of difficult learning subjects like general principles of Civil Law and for the clarification of its difficult terminology indicates successful results. Compared to the traditional lecture-based teaching, the use of Drama seems significantly more effective in achieving Legal Literacy.

Legal literacy in the present research was identified as a group of five factors: "Distinction between Law and Ethics", "Grammatical or Logical Interpretation of Law", "Definition of Rights (claim and abuse)", "Subject to Legal Action (natural or legal person)" and "Validity of a legal Act". 
Quantitative analysis of data showed a statistically significant improvement for the experimental group in comprehension and perception of the above legal meanings, if compared to the control group that was traditionally taught.

Beyond these results, qualitative data revealed delicate qualities in the learning process. Positive respond of the students to the new teaching method helped the transformation of the juridical language into practical and everyday examples and the better perception of Legal Literacy. Students accepted gradually the new way of teaching and identified it as freedom of expression. In addition, team bonding assisted the learning process where different points of view of each different participant, led to multidimensional study of the subject. This can be considered very important, for this is the point when legislating. Furthermore, self-concentration appeared as another benefit between participants that assisted the learning process.

Finally, during interventions participants had the chance to discover new skills that in a way gave them more confidence. Self confidence is a basic component when claiming rights, therefore is required in matters of Legal literacy.

\section{Conclusion}

This research suggests the introduction of Civil law into general education senior high school, as, beyond any doubt, Legal literacy is an important part of citizen's general education. Difficulties in clarification of legal terms posed this knowledge in third-grade specialized education.

Civil law as a school lesson can be proved complicated due to its theoretical nature and the difficulty of correlating legal terms with practical examples of everyday social life.

The use of Drama in education emphasizes in critical thinking (Alkistis, 2008: 77). By provoking discussions and criticism, Drama enlightens social issues (Sextou, 2007:24). Adolescents of secondary education are the future adult citizens. They will be able to take decisions as equal members of the society only if they are legally literate (UNESCO, 2017: 15). Role playing through Drama gives them the opportunity of interacting and examining dilemmas under different points of view. This is exactly the way the legislative system should work. Drama as a way of understanding reasonable logic of the legislative system copies the way this system works, therefore can be proved as an effective tool for Legal literacy. 


\section{References}

\section{English}

Anderson, A., Basilevsky, A., Hum, D. (1983). Scaling techniques. In P. Rossi, J. Wright, \& An. Anderson (Ed.) Handbook of Survey Research: Quantitive Studies in Social Relations (pp.246-281). Massachussets: University of Massachusetts Academic Press.

Barkley, E., Cross, P., Major, C.H. (2005).Collaborative learning techniques: a handbook for college faculty. San Francisco: Jossey-Bass.

Berk, R. A. (1990).Importance of expert judgment in content-related validity evidence.Western Journal of Nursing Research, 12(5), 659-671.

Bunker, L. (1991). The Role of play and motor skill development in building children's self-confidence and self-esteem. The Elementary School Journal, 9(5), 467-471.

Cronbach, L. J. (1951). Coefficient alpha and the internal structure of tests. Psychometrika, 16(3), 297-334.

Fransen, W.J., (2003). Process drama and creative problem solving: an Integrated Approach. Dissertation in Fine Arts, Texas Tech University Library.

Friedland, S. (1996). How we teach: A survey of teaching techniques in American law schools. Seattle University Law Review, 20(1), 1-44.

Gervais, M. (2006). Exploring moral values with young adolescents through process drama. International Journal of Education \& the Arts, 7(2), 1-34.

Ipsos MORI (2016). Online survey of individuals' handling of legal issues in England and Wales 2015. The Law Society \& Legal Services Board, UK. Recovered by : http://www.lawsociety.org.uk/support-services/ research-trends/largest-ever-legal-needs-survey-in-england-and-wales. Date of visit: 19/4/2017.

Landy, R. (1982).Handbook of educational drama and theatre. Connecticut: Greenwood Press.

Neelands, J., \& Goode, T. (2015).Structuring drama work, 3d Edition. Cambridge: Cambridge University Press.

OECD (2012).Greece: review of the central administration (Greek Version): OECD Public Governance Reviews. OECD Publishing.

O'Neill, C. (1995). Drama worlds, a framework for process drama. Portsmouth: Heineman.

O'Toole, J. (1992). The process of drama: Negotiating Art and Meaning. London: Routledge.

Pereira, C. (1988). Law related education in elementary and secondary school, Eric Digest, ED296948 198806-00, https://files.eric.ed.gov/fulltext/ED296948.pdf

Reason, P., \& Bradbury, H. (Eds.). (2008). Handbook of action research: participative inquiry and practice. London: Sage Publications.

Scully-Hill, A., Lam, P., \& Yu, H., (2010). Beyond Role Playing: Using Drama in Legal Education. Journal of Legal Education, 60 (1), 147-157.

Singh, K. (2007). Quantitative social research methods. New Delhi: Sage Publications

Stuckey, R. T. (2007). Best practices for legal education: a vision and a road map. South Carolina: Clinical Legal Education Association.

Swaffield, S., \&MacBeath, J. (2005).School self-evaluation and the role of a critical friend. Cambridge Journal of Education, 35(2), 239-252.

Taylor, P., \& Warner, C. D. (2006) Structure and spontaneity-the process drama of Cecily O'Neill. London: Institute of Education Press.

Tofteng, D. \& Husted, M. (2011). Theatre and action research: How drama can empower action research processes in the field of unemployment. , 9(1) 27-41.

U.N.E.S.C.O., (ed) (2017): Reading the past, writing the future: fifty years of promoting lliteracy, France. Recovered: http://unesdoc.unesco.org/images/0024/002475/247563e.pdf (Data base: UNESDOC of UNESCO). Date of visit: 17/4/2017. 
Zanouzani Azad, L. (2012). Fairness through legal literacy: a case for active involvment. Master's Thesis, University of Waterloo, Ontario, Canada.

Zariski, A. (2011). Legal literacy: An introduction to legal studies. Edmonton: AthabascaUniversityPress.

\section{Greek}

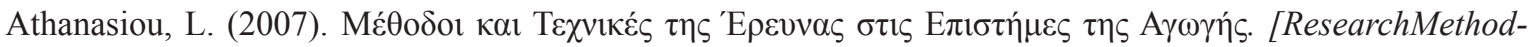

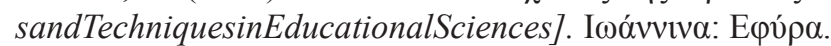

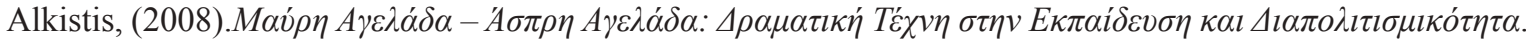

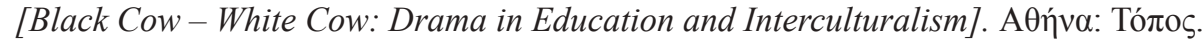

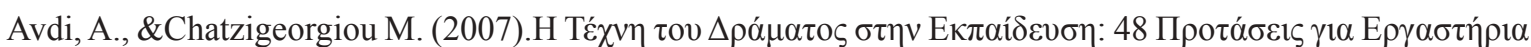

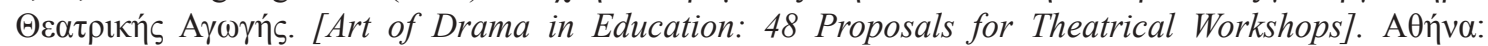

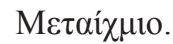

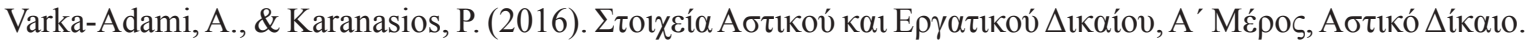

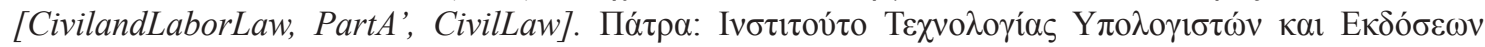

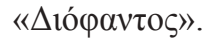

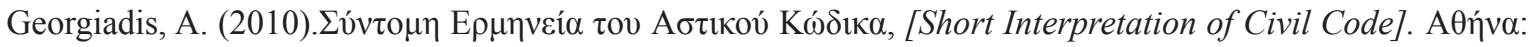

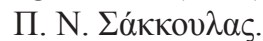

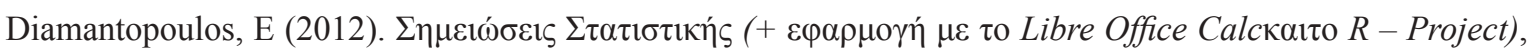

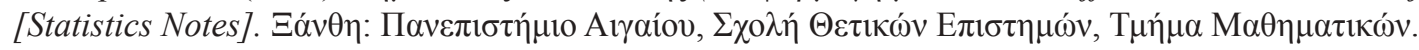

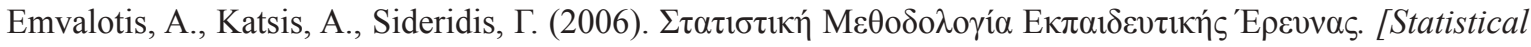

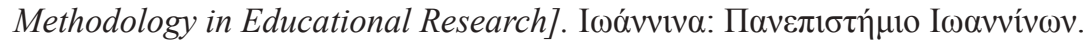

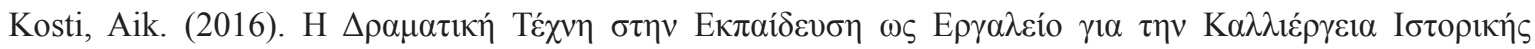

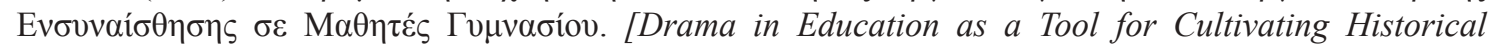

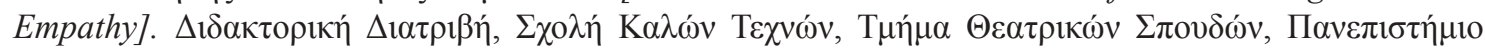

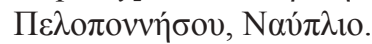

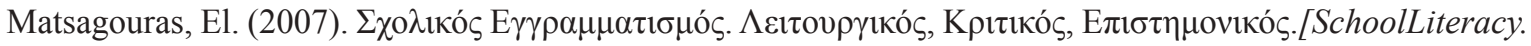

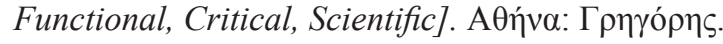

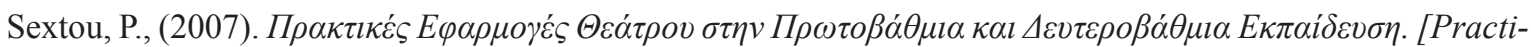

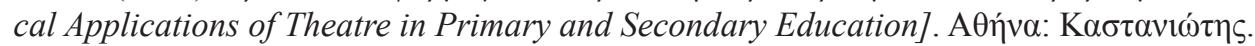

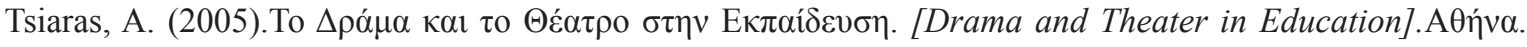

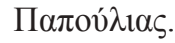





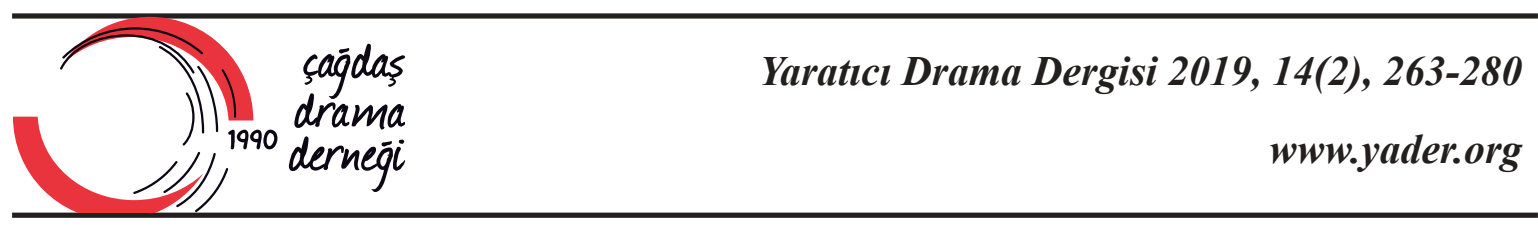

\section{Müzede Sosyal Bilgiler Öğretiminde Yaratıcı Dramanın Bir Yöntem Olarak Kullanımına İlişkin Uzman Görüşleri*}

Merve Ulu ${ }^{1}$

Ferah Burgul Adıgüzel ${ }^{2}$

\begin{tabular}{|c|c|}
\hline Makale Bilgisi & Öz \\
\hline DOI: $10.21612 /$ yader.2019.015 & Bu araştırmanın amacı, müzede sosyal bilgiler öğretiminde yaratıcı drama yönteminin \\
\hline Makale Geçmişi & yaratıcı dramanın bir yöntem olarak kullanılmasında yaşanan sorunlar ve çözüm \\
\hline Geliş tarihi & önerileri incelenmiştir. Çalışmada nitel araştırma yöntemi kullanılmıştır. Çalışma \\
\hline Kabul & $\begin{array}{l}\text { kapsamında ulaşılan veriler yarı yapılandırılmış görüşme formu aracıll̆̆̆yla } 12 \text { alan } \\
\text { uzmanıyla yapılan görüşmeler ile toplanmıştır. Alan uzmanları sosyal bilgiler, müzede } \\
\text { eğitim ve yaratıcı drama alanlarının en az birinde lisansüstü eğitim almış ve en az } 5\end{array}$ \\
\hline Anahtar Sözcükler & ylllı tecrübeye sahip eğitimcilerden oluşmuştur. Verilerin analizinde betimsel analiz \\
\hline Sosyal bilgiler öğretimi & kullanılmıştır. \\
\hline Müzede ĕgitim & Araştırma sonucunda, uzmanlar tarafindan sosyal bilgiler öğretimi sürecinde konu, \\
\hline Müzede öğrenme & amaç ve kazanım ortaklıklarından dolayı müzelerin kullanıması gerektiği, sıklıkla \\
\hline Yaratıcı drama & $\begin{array}{l}\text { yaratıcı drama yöntemi ve tekniklerinin önerildiği, dersin disiplinlerarası yapısı } \\
\text { nedeniyle tüm sosyal bilgiler konularının müzelerde yaratıcı drama yöntemi ile } \\
\text { işlenmeye uygun bulunduğu sonucuna ulaşılmıştır. Uzmanlara göre müzede sosyal }\end{array}$ \\
\hline Makale Türü & bilgiler öğretimi uygulama süreçlerinde en sık yaşanan sorunlar; ögretmenin donanım \\
\hline Araştırma Makalesi & $\begin{array}{l}\text { yetersizliği, müze görevlilerinin uygulama gerektiren çalışmalara olumlu bakmaması } \\
\text { ve ulaşımdır. Sunulan çözüm önerileri arasında ögretmen eğitimi, müzelerde eğitim } \\
\text { alanlarının oluşturulması ve proje tabanlı çalışmaların yapılması yer almaktadır. }\end{array}$ \\
\hline
\end{tabular}

* $\quad$ Bu makale Merve Ulu tarafindan hazırlanan "Müzede Sosyal Bilgiler Öğretiminde Yaratıcı Dramanın Bir Yöntem Olarak Kullanımına İlişskin Uzman Görüşleri” başlıklı yüksek lisans tez çalı̧̧masından üretilmiştir.

1 Yüksek Lisans Öğrencisi, Gazi Üniversitesi Eğitim Bilimleri Enstitüsü Drama ve Eğitim Anabilim Dalı, Ankara, Türkiye.

E-posta: verveulu@gmail.com. Orcid ID: https://orcid.org/0000-0002-1037-794X

2 Dr., Gazi Üniversitesi Gazi Eğitim Fakültesi Türk Dili ve Edebiyatı Eğitimi Anabilim Dalı, Ankara, Türkiye. E-posta: fburgul@gmail.com Orcid ID: https://orcid.org/0000-0003-1962-0712 


\section{Opinions of the Experts on Employing Creative Drama as a Method in Social Studies Teaching in the Museum}

\begin{tabular}{lr}
\hline Article Info \\
\hline DOI: $10.21612 /$ yader.2019.015 \\
\hline Article History & \\
Received & 30.03 .2019 \\
Accepted & 01.07 .2019
\end{tabular}

Keywords

Teaching of social studies

Education in museum

Learning in the museum

Creative drama

Article Type

Research paper

\begin{abstract}
The purpose of this study is to examine the opinions of the experts on employing creative drama method in social studies teaching in the museums. This study accordingly examined the problems and solutions occurred during the employment of creative drama as a method. The study uses the qualitative research method. The collected data are based on the semi-structured interviews conducted with 12 field experts. The field experts consist of people whom have at least graduated from postgraduate degrees and have 5-year experience on social sciences, education in the museum and creative drama. The employed method on the analysis of the data is descriptive analysis method.

In conclusion, the results of the study suggest that museums are suitable places for social sciences teaching, propose employing creative drama method and techniques while concluding that the creative drama methods are suitable to teach social sciences in museums in accordance with the interdisciplinary nature of the lesson. According to experts, the most frequently encountered problems are; incompetency of the teacher, the negative approach of the museum officials to the studies that require practice, and transportation. The suggested solutions include the training of the teachers, creating study areas in museums and conducting project-based studies.
\end{abstract}




\section{Giriş}

Klasik müzecilik anlayışında müzeler, nesnelerin toplanıp korunduğu ve sergilendiği yerler olarak değerlendirilirken bu anlayış zamanla yerini eğitim işlevi ile paylaşmaya başlamıştır. Müze eğitimi kavramı, müzelerin eğitim amacıyla kullanılmasını ifade eder. Müzelerin birer eğitim aracı olarak görülmesine ilişkin gelişmelerin ise 15. yüzyılda başladığı düşünülmektedir. Onur'a (2013) göre; müze kelimesi bilginin ilerlemesine katkıda bulunan kurum anlamında ilk kez 1683 yılında İngiltere'de kullanılmıştır. Müze eğitimi, Fransız İhtilâli sonrasında Fransa'da önem kazanmıştır. Benzer şekilde Tezcan, Akmehmet ve Ödekan (2006) müzecilikte müze yoluyla halkın eğitimi misyonunun Fransız İhtilâli ile kazanıldı̆̆ını belirtmektedirler. Duncan'a göre müzelerin birer eğitim aracı olarak görülmesi 1727 yılını bulmaktadır ve bu konu Casper Neickel'in yazdığı aynı tarihli "Museographia” isimli eserde belirtilmiştir. Journal of Museums'da (1980) İngiltere'de 17. yüzyılda açılan Haslemere Müzesi ilk eğitsel müze olarak kabul edilmektedir. Müze ve okul ilişkisinin kurulması ise bu müzenin öğrenci grupları tarafından ziyaret edilmeye başlaması ile olmuştur (San, 2018). Çağdaş anlamda müzede eğitim Onur'a (2013) göre 1970'li yıllarda gündeme gelmiştir. Müzecilikteki gelişmelerle birlikte; bu mekânlar etkileşimli, yaşantı odaklı, eğitim aracı ve kültürel mirasın aktarıcısı olma gibi misyonları kazanmıştır. Çağdaş müzecilik anlayışı ile ziyaretçiler, müzeleri kendilerini güvende hissettikleri, eğlendikleri ifade edebilecekleri ortamlar olarak görerek burada farklı disiplinleri keşfederek öğrenmeye başlamışlardır (Güler, 2019). Çağdaş müze eğitimi anlayışında yaşantı odaklı öğrenme süreçlerinin kullanımına önem verildiğinden, müze eğitiminde kullanılan yöntem ve teknikler de genellikle bireyin aktif olduğu (nesne tamamlama, ara-bul, ilk anket-son anket vb.) yöntem ve tekniklerdir. Müze ziyaretlerinde geleneksel anlayışın aksine müzedeki koleksiyonlar ile etkileşime geçildiği için bireyler farklı disiplinleri ve alternatif öğrenme yöntemlerini deneyimleyeme imkânı bulabilmektedirler. Müzeler, gerçek nesneleri barındırmaları nedeniyle okul dersleriyle ve yaşamla bağ kurulabilecek öğrenme ortamları olarak kullanılabilmektedirler. Hooper Greenhill'e (1999) göre "Müze ziyaretleri müfredatı desteklemek için yapıldığında, müzeler, çocukların öğrenme deneyimlerini ileriye taşımakta eşsiz değere sahiptir." Müzelerin okul derslerinde kullanımı ile ilgili Alkış ve Güleç (2003)'in sosyal bilgiler öğretiminde müze gezilerinin kullanımını inceledikleri çalışmada, müzelerin derslerde tercih edilme nedenlerinin ilk sırasında farklı duyu alanlarını desteklemeleri ve öğrenmede kalıcılığı arttırmaları yer almaktadır. $\mathrm{Bu}$ nedenle okul dersleri kapsamında müzelerden ve müzelerde yaşantı merkezli öğrenme süreçlerinden faydalanılması önemlidir. Yaratıcı drama bu süreçlerde kullanılabilecek etkileşimli yöntemlerden biridir. Okvuran'a (2012) göre yaratıcı dramanın müzelerde kullanılmasında temel amaç müze koleksiyonların incelenmesidir. Bu yolla müze ile etkileşime geçilebilmektedir. San (2018)'ın çalışmasında yaratıcı dramanın müzede kullanımı ile ilgili yer alan ifadeler son derece önemlidir:

“Şu bir gerçektir ki artık gelişmiş ülkelerde müzelerde drama yapmalı muyı tartışmaları çoktan bitmiştir; müzelerde dramayl yararlı kılmanın en iyi yöntemi nedir konusu tartışllmaktadır. Müzede drama eğitimsel amaç ve hedeflere ulaşılmasında tiyatro tekniklerinden yararlanarak çocukları dramanın içine alır, onlardan sı sılk rol oynamalarını ister. Böylece cansız nesnelerle bireyler arasında bir başka kişi ya da kişiler aracılığıyla didaktik ve kuru olmayan eğlenceli bir ilişki kurulur. Başka hiçbir yorumlama tekniği bu bağlantıyı bu biçimde gerçekleştiremez." (Earl'den aktaran San, 2018). 
Eğitimde müzenin ve müzede yöntem olarak yaratıcı dramanın kullanımı öğrenmeyi olumlu etkilemektedir. Bununla ilgili olarak Adıgüzel ve Başbuğ (2019)'un sosyal bilgiler derslerini yaratıcı drama yöntemi ile müzede işledikleri çalışmada, bu yöntemin öğrenmeyi kolaylaştırması ve akademik başarıyı arttırması açısından etkili olduğu belirtilmiştir. Eğitimde müzelerin ve yaratıcı drama yönteminin kullanımının gerekliliğine 2004-2005 Sosyal Bilgiler Dersi Öğretim Programı'nda “Programın Uygulanması ile İlgili Açıklamalar” bölümünün 11. Maddesinde de, öğrencilerin sınıfta y a da müzede drama etkinlikleri ile geçmiş yaşantıların canlandırmasını ve tarihî kişilikler ile empati kurmaları gerektiği ifadeleri ile yer verilmiştir (MEB, 2004).

Sosyal bilgiler öğretimi, müzede eğitim ve yaratıcı drama alanlarında ilgili alan yazın incelendiğinde sosyal bilgiler öğretimini müzede yaratıcı drama yöntemi açısından bütünsel bir şekilde inceleyen oldukça sınırlı sayıda çalışmaya ulaşılmıştır. Yaratıcı dramanın sosyal bilgilerde ve müze eğitiminde kullanımına yönelik ulaş1labilen lisansüstü çalışmalar Turgut'un (2015) "Sosyal Bilgiler Dersinde Bir Eğitim Aracı Olarak Sanal Müze Kullanımı”, Aykaç (2008)'ın "Sosyal Bilgiler Dersinde Yaratıcı Dramanın Yöntem Olarak Kullanılmasının Öğrenci Başarısına Etkisi”, Akyüz (2009)'ün Sanayi Müzelerinin Tarih Eğitiminde Kullanım Durumu: Rahmi Koç Müzesi Örneği, Başbuğ (2017)’un “Müzede Yaratıcı Drama Yönteminin Sosyal Bilgiler Dersindeki Öğrencilerin Başarısına Etkisi” başlıklı çalışmalardır. Yaratıcı dramanın müzede yöntem olarak kullanımının geliştirilmesi için öncelikle bu alanlardaki ihtiyaç ve sorunları belirlemek önemlidir. Ancak müzede sosyal bilgiler öğretiminde yaratıcı dramanın bir yöntem olarak kullanımına ilişkin uzman görüşlerinin incelendiği bir çalışmaya ulaşılamamıştır. Bu nedenle yaratıcı drama, sosyal bilgiler ve müze eğitimi alanlarında uzman olan eğitimcilerden alınan görüşlerin bu alanların gelişimi açısından önemli olduğu düşünülmektedir.

\section{Araştırmanın Amacı}

Araştırmanın amacı, müzede sosyal bilgiler öğretiminde yaratıcı dramanın bir yöntem olarak kullanımına ilişkin uzman görüşlerinin incelenmesidir. Uzman görüşlerinden hareketle sosyal bilgiler öğretimi, müzede eğitim ve yaratıcı drama yöntemi arasındaki ilişki belirlenerek sosyal bilgiler yaratıcı drama yönteminin müzede kullanımına ilişkin sorunlar tespit edilmiş ve bu sorunların çözümüne ilişkin öneriler sunulmuştur. Bu kapsamda aşağıdaki sorulara yanıt aranmıştır:

1. Alan uzmanlarının, müzede sosyal bilgiler öğretimi sürecinde kullanılabilecek yöntem ve tekniklere ilişkin görüşleri nelerdir?

2. Alan uzmanlarının, yaratıcı drama yönteminin müzede kullanımında sosyal bilgiler dersi konularına ilişkin görüşleri nelerdir?

3. Alan uzmanlarının müzede sosyal bilgiler öğretiminde yaratıcı drama yönteminin kullanımında yaşanılan sorunlara ilişkin görüşleri nelerdir?

4. Alan uzmanlarının müzede sosyal bilgiler öğretiminde yaratıcı drama yönteminin kullanımında yaşanılan sorunlara ilişkin çözüm önerileri nelerdir? 


\section{Yöntem}

\section{Araştırma Modeli}

Çalışmada nitel araştırma yöntemlerinden biri olan temel yorumlayıcı nitel araştırma deseni kullanılmıştır. Eğitim bilimlerinde yaygın olarak kullanılan bu desen, insanların bir konuyu nasıl yapılandırıp yorumladıklarını anlamaya yönelik olan çalışmalarda tercih edilmekte ve bu süreçte görüşme, gözlem, doküman incelemesi gibi veri toplama araçlarından yararlanılmaktadır (Marriam, 2018). Çalışmada temel yorumlayıcı nitel araştırma deseninin seçilmesinin nedeni; çalışma grubundan görüşme yoluyla derinlemesine veri elde edilmek istenmesi, desenin araştırmada hedeflenen amaçlara ulaşmada kolaylık sağlaması, kullanılmak istenen yöntem ve teknikleri içermesi ve nitel araştırmalarda yaygın olarak tercih edilmesidir.

\section{Çalışma Grubu}

Çalışma grubu 12 alan uzmanından oluşmaktadır ve amaçlı örnekleme yolu ile seçilmiştir. Büyüköztürk (2012)'e göre amaçlı örnekleme, araştırmanın amacı doğrultusunda zengin bilgi içeren örneklerin seçilmesidir. Bu kapsamda kullanılan tipik durum örneklemesi ise evreni en iyi temsil edecek örneklemin seçilmesidir. Bu nedenle çalışma grubunun seçilmesinde amaçlı örnekleme yöntemlerinden tipik durum örneklemesi kullanılmıştır. Çünkü araştırma kapsamında çalışma grubunun, derinlemesine bilgi alınabilecek ve çalışma evrenini en iyi şekilde temsil edecek uzmanlardan oluşturulmasına gereksinim duyulmuştur. Çalışma grubunun sosyal bilgiler, yaratıcı drama, müzede eğitim konularında lisansüstü ve uluslararası alanda geçerliliği olan eğitimler almış, bu alanların en az birinde ve en az 5 yıl tecrübeye sahip eğitmenlerden oluşması ölçüt alınmıştır.

Tablo 1. Uzman Grubunun Uzmanlık Alanları ve Çalışma Sürelerine İlişskin Veriler

\begin{tabular}{llll}
\hline \multicolumn{3}{c}{ Çalışma Süresi (Yıl) } \\
\hline Uzman & Sosyal Bilgiler & Müzede Ĕgitim & Yaratıcı Drama \\
\hline U1 & $25-30$ & $25-30$ & $25-30$ \\
\hline U2 & $15-20$ & $15-20$ & $15-20$ \\
\hline U3 & $10-15$ & $10-15$ & $10-15$ \\
\hline U4 & $10-15$ & $10-15$ & $10-15$ \\
\hline U5 & $20-25$ & $20-25$ & - \\
\hline U6 & $10-15$ & $10-15$ & - \\
\hline U7 & $10-15$ & $10-15$ & $10-15$ \\
\hline U8 & $5-10$ & $10-15$ & $10-15$ \\
\hline U9 & $25-30$ & $10-15$ & $15-20$ \\
\hline U10 & $10-15$ & $10-15$ & $10-15$ \\
\hline U11 & $15-20$ & $5-10$ & $5-10$ \\
\hline$U 12$ & $15-20$ & $10-15$ & $10-15$ \\
\hline
\end{tabular}


Tablo 1 incelendiğinde; görüşmeye 12 alan uzmanının katıldığı görülmektedir. Uzmanların sosyal bilgiler alanında çalışma süreleri incelendiğinde, uzmanlardan 1'inin bu alanda 10 yıldan az, 8'inin 10-20 yıl arasında, 3'ünün ise 20 yıldan fazla bir süredir bu alanda çalıştığı belirlenmiştir. Uzmanların müzede eğitim alanında çalışma süreleri incelendiğinde; 1 uzmanın 10 yıldan az, 9 uzmanın 10-20 yıl arasında, 2 uzmanın 20 yıldan fazla bir süredir bu alanda çalıştığı görülmektedir. Yaratıcı drama alanında ise 1 uzmanın 10 yıldan az, 8 uzmanın 10-20 yıl arasında, 1 uzmanın 20 yıldan fazla bir süredir bu alanda çalıştığı görülmektedir. 2 uzman yaratıcı drama alanında çalışmamış olup U5'in müze ve sosyal bilgiler alanında çalışma süresi 20 yıldan fazla ve U6'nın ise 10-15 yıl arasindadir.

12 uzmandan oluşan görüşme grubunda yer alan uzmanlar; öğretmen, akademisyen, yaratıcı drama eğitmeni ve müze eğitimcilerinden oluşmaktadır. Alan uzmanlarının 9'u doktora, 3'ü yüksek lisans eğitimi almıştır. 12 uzmanın tümü müzede eğitim, 11'i yaratıcı drama eğitimi almıştır. Uzmanların 8'i üniversitede, 2'si MEB bünyesindeki okullarda, 2'si özel kurumlarda çalışmaktadır. Çalışma grubu, çalıştıkları alan ve çalışma sürelerine ilişkin edinilen bu bilgiler sonucunda görüşme yapmaya uygun bulunmuştur.

\section{Veri Toplama Araçları}

Araştırmada detaylı veri elde edebilmek için yarı yapılandırılmış görüşme formu kullanılmıştır. Nitel araştırmalarda yaygın şekilde kullanılan yarı yapılandırılmış görüşme tekniği, soruların önceden hazırlandığı, araştırmacının görüşme sırasında yeni sorular sorabildiği bir veri toplama yöntemidir (Güler, Hacıoğlu, Taşğın, 2015). Görüşme formu iki bölümden oluşmaktadır. İlk bölümde çalışma grubunun yaş, çalışma süreleri, çalıştıkları kurum türleri gibi demografik bilgilerine ilişkin sorular bulunmaktadır. Formun ikinci bölümünde ise görüşme soruları yer almaktadır. Görüşme formu hazırlanırken soruların uygunluğu ve kapsamı ile ilgili olarak, müzede eğitim, yaratıcı drama ve sosyal bilgiler alanlarında çalışan iki akademisyenin ve bir ölçme değerlendirme uzmanının görüşleri alınmıştır. Görüşme formunun hazırlanmasının ardından iki uzman ile pilot uygulama yapılarak form üzerinde gerekli düzenlemeler gerçekleştirilmiştir. Görüşme formunda 4 soru yer almaktadır. Alan uzmanlarının sosyal bilgiler öğretiminde yaratıcı drama yönteminin kullanımına ilişkin görüşleri, araştırma kapsamında oluşturulan dört ana tema altında incelenmiştir. Bu temalar; müzede sosyal bilgiler öğretimi sürecinde kullanılabilecek yöntem ve teknikler, yaratıcı drama yöntemi ile müzede işlenebilecek konular, bu süreçte yaşanan sorunlar ve sorunlara ilişkin çözüm önerileridir. Bu temalar kapsamında alan uzmanlarına yöneltilen sorular şu şekildedir:

1. Sizce müzede sosyal bilgiler öğretimi sürecinde kullanılabilecek yöntem ve teknikler nelerdir?

2. Sizce müzede sosyal bilgiler dersi kapsamında hangi konular yaratıcı drama yöntemiyle işlenebilir?

3. Sizce müzede sosyal bilgiler öğretiminde yaratıcı drama yönteminin kullanımında yaşanan sorunlar nelerdir?

4. Müzede sosyal bilgiler öğretiminde yaratıcı drama yönteminin kullanımında yaşanan sorunların çözümüne ilişkin önerileriniz nelerdir? 


\section{Geçerlik ve Güvenirlik}

Görüşme sırasında diyalogların kesintiye uğramadan devam etmesi ve objektif şekilde daha fazla veri elde edilmesi sağlanmıştır. Görüşme sürecinde ifadeler arasındaki ilişkinin daha kolay kurulması ve açıklanabilmesi için yazılı notlar alınmıştır.

Çalışmanın geçerlik ve güvenirliğini arttırmak amacıyla Yıldırım (2010)'ın çalışmasında yer alan Maxwell (1992)'in nitel geçerliği arttırma ölçütlerine, ayrıca Twycross ve Shields (2005)'ten uyarlanmış nitel geçerliği ve güvenirliği arttırmada denetleme stratejisine dikkat edilmiştir. $\mathrm{Bu}$ kapsamda çalışmanın konusu araştırmanın amacına uygun şekilde betimlenerek betimsel geçerliği artırmak amaçlanmıştır. Yorumlayıcı geçerliği arttırmak için, benzer konularda yapılmış araştırmalardan örnekler sunulmuştur. İç geçerlik (kuramsal geçerlik için araştırmanın bütünlük oluşturacak biçimde, sonuçları birbiri ile ilişkilendirilerek verilmiştir. Dış geçerlik (genellenebilirlik) için araştırmanın amacı kapsamında çalışılan konuyu temsil edecek bir çalışma grubu seçilmiştir. Uygunluğu arttırmak için ulaşılan sonuçların ilgili durumlara da uyarlanıp uygulanabilmesi amacıyla ilgili konularda çalışan diğer uygulayıcıların yaşadıkları sorunlara da çözümler sunulmuştur. Yıldırım (2010) tarafindan yer verilen Twycross ve Shields (2005)'in kısa yoldan denetleme stratejisi dikkate alınarak aşama aşama veriler kopyalanıp, düzenli şekilde kontrol edilmiş ve gerekli düzenlemeler yapılmıştır. Bu süreçte veri toplama araçları, verilerin toplanması ve çözümlenmesi ile ilgili bilgiler ayrıntılı olarak açılanmıştır. Araştırmaya ilişkin veriler uzman görüşlerine göre ve orijinal kaynaklarla (ses kayıtları, öğretim programları) karşılaştırılıp yorumlanmıştır. Araştırma konusu, uzman görüşleri referans alınarak incelenmiş, çalışma süreci ve veri toplama araçları benzer konularda çalışma yapmış araştırmacılar tarafından da incelenmiştir.

\section{Verilerin Toplanması}

Görüşme verilerinin toplanması sürecinde 12 alan uzmanından e-posta ve telefon aracılığıyla randevu talep edilmiştir. 7 uzman ile yüz yüze görüşme, 3 uzman ile e-posta aracıllğıyla, 2 uzman ile telefonla görüşme sağlanmıştır. 7 uzmandan 1'i ile teknik sorunlar nedeniyle görüşmenin bir kısmı yazılı bir kısmı yüz yüze yapılmıştır. Görüşmeye başlarken görüşmenin amacı, ortalama süresi, soru sayısı gibi konularda bilgi verilmiş, ses kaydının alınması konusunda izin alınmıştır. Görüşme sürecini desteklemek ve uzman ifadelerine yönelik bir takım açıklayıcı bilgilere yer vermek için yazılı notlar kullanılmıştır. Görüşme sorularının daha iyi algılanarak sürecin verimli geçmesini sağlamak amacıyla, alan uzmanlılarına görüşme formunun bir kopyası verilmiştir. Görüşme sonrasında ses kayıtları yazılarak metin hâline getirilmiştir.

\section{Verilerin Analizi}

Çalışma verilerinin analizinde, verileri sınıflandırıp bir bütünlük içerisinde özetleyip yorumlamak ve derinlemesine bilgi edinebilmek için betimsel analiz yöntemi kullanılmıştır. Betimsel analiz; araştırma sorularından hareketle genel bir çerçevenin çizildiği, elde edilen verilerin temalarla ilişkilendirildiği ve bulguların doğrudan alıntılara yer verilerek açıklandığı bir analiz yöntemidir (Yıldırım ve Şimşek, 2003). Bu doğrultuda görüşme formunda yer alan sorular için önceden oluşturulan temalar; sosyal bilgiler öğretiminde müzede kullanılabilecek yöntem ve teknikler, yaratıcı drama yöntemi kullanılarak müzede işlenebilecek konular, yaşanan sorunlar ve geliştirilen çözüm önerileridir. Creswell'e göre nitel araştırmalarda oluşturulan kod ve temalardaki veriler betimlenip sınıflandırılır, yorumlanır ve sunulur. Araştırmacı isteğe bağlı olarak bu kodların sıklığını hesaplayabilir. (Creswell, 2016). 
Görüşmelere ilişkin verilerin yer aldığ 1 formlar okunarak genel bir çerçeve çizilmiş ve analiz için hazırlık yapılmıştır. Veriler analiz edilirken objektif bir bakış açısı sağlamak amacıyla uzmanlar "U1, U2, U3 ..." şeklinde kodlanmıştır. Veriler ilgili oldukları üst temalarla ilişkilendirilmişlerdir. Bir sonraki basamakta detaylı inceleme yapılarak veriler arasındaki ilişki, bu temalar altında açıklanmış ve yorumlanmıştır. Ulaşılan sonuçlar görselleştirilerek tablolar halinde açıklanmış ve tablolarda hesaplanan frekans, yüzde dağılımlarına yer verilmiştir. Ulaşılan sonuçları desteklemek amacıyla uzman görüsslerinden doğrudan alıntılara yer verilmiştir. Son olarak veriler, aralarında nedensellik ilişkisi kurularak ve ilgili alan yazın ile karşılaştırma yapılarak açıklanmıştır.

\section{Bulgular}

Bu bölümde müzede sosyal bilgiler öğretimi sürecinde yaratıcı dramanın bir yöntem olarak kullanılmasına ilişkin uzman görüşlerinden hareketle ulaşılan bulgulara yer verilmiştir.

\section{Müzede Sosyal Bilgiler Öğretimi Sürecinde Kullanılması Önerilen Yöntem ve Tekniklere İliş̧kin Bulgular}

Sosyal bilgiler derslerinde müzeler kullanılırken tercih edilebilecek yöntem ve tekniklere ilişkin uzman görüşleri Tablo 2'de gösterilmiştir.

Tablo 2. Müzede Sosyal Bilgiler Öğretimi Sürecinde Kullanılması Önerilen Yöntem ve Teknikler

Müzede sosyal bilgiler öğretiminde önerilen yöntem, teknik ve uygulamalar

\begin{tabular}{|c|c|c|c|}
\hline Yöntem / Teknik / Uygulama & Uzmanlar & $\mathrm{f}$ & $\%$ \\
\hline Yaratıcı Drama ve Teknikleri & $\begin{array}{l}\text { U1, U2, U3, U4, U5, U6, U7, U8, U9, } \\
\text { U10, U11, U12 }\end{array}$ & 12 & 100 \\
\hline Canlandırma aşaması & U1, U2, U3, U4, U5, U8, U9, U10, U12 & 9 & 75 \\
\hline Tüm yöntem ve teknikler & U1, U5, U6, U8, U11 & 5 & 41,6 \\
\hline Donuk imge & U1, U4, U5, U7 & 4 & 33,3 \\
\hline Altı şapka & U3, U11 & 2 & 16,6 \\
\hline Rol oynama, doğaçlama & U4, U12 & 2 & 16,6 \\
\hline Gözlem & $\mathrm{U} 1, \mathrm{U} 2$ & 2 & 16,6 \\
\hline Gezi & U1 & 1 & 8,3 \\
\hline Görüş geliştirme & U11 & 1 & 8,3 \\
\hline Geriye dönüş & U4 & 1 & 8,3 \\
\hline Kavram haritas1 & U1 & 1 & 8,3 \\
\hline Rol içinde yazma & U1 & 1 & 8,3 \\
\hline Toplantı tekniği & U1 & 1 & 8,3 \\
\hline Fotoğraf anı & U1 & 1 & 8,3 \\
\hline İstasyon, örnek olay incelemesi & $\mathrm{U} 3$ & 1 & 8,3 \\
\hline Araştırma & $\mathrm{U} 2$ & 1 & 8,3 \\
\hline Yazma-çizme & $\mathrm{U} 2$ & 1 & 8,3 \\
\hline Nesneleri yeniden oluşturma & $\mathrm{U} 2$ & 1 & 8,3 \\
\hline Sunum & U10 & 1 & 8,3 \\
\hline Ara bul, birbirine anlatma & U8 & 1 & 8,3 \\
\hline Kroki çizme & U12 & 1 & 8,3 \\
\hline Hikâye yazma & U12 & 1 & 8,3 \\
\hline İkili grup gözler kapalı müzeyi gezme & U12 & 1 & 8,3 \\
\hline Nesne fotoğrafları & U12 & 1 & 8,3 \\
\hline
\end{tabular}


Tablo 2 incelendiğinde, sosyal bilgiler öğretiminde müzelerden faydalanırken kullanılabilecek yöntem ve tekniklere en çok “yaratıcı drama yöntemi ve teknikleri” örneği verilmiştir. 12 alan uzmanı yaratıcı drama yöntemi ve tekniklerini belirtmiştir $(f=12, \% 100)$. Müzede canlandırma çalışması yapılabileceğini belirten uzman sayısı 9'dur $(f=9, \% 75) .5$ alan uzmanı ise tüm yöntem ve tekniklerin kullanılabileceğini belirtmiştir $(f=5, \% 41,6)$. Donuk imge $4(f=4, \% 33,3)$, altı şapka $2(f=2, \% 16,6)$, rol oynama-doğaçlama $2(f=2, \% 16,6)$, gözlem $2(f=2, \% 16,6)$ alan uzmanı tarafindan yer verilen tekniklerdendir. Görüş geliştirme, geriye dönüş, kavram haritası, rol içinde yazma, toplantı tekniği, fotoğraf anı, istasyon, örnek olay incelemesi, araştırma, yazma-çizme, nesneleri yeniden oluşturma, sunum, ara bul, birbirine anlatma teknikleri ise her biri için 1 alan uzmanı tarafından örnek verilen tekniklerdendir $(f=1, \% 8,3)$. Adı geçen diğer uygulamalar ise kroki çizme, hikâye yazma, ikili grup gözler kapalı müzeyi gezme, nesne fotoğraflarından yararlanma şeklinde sıralanmaktadır ve her birine 1 alan uzmanı tarafından yer verilmiştir $(f=1, \% 8,3)$.

Yaratıcı drama yöntemi ve teknikleri örneğine yer veren U1'in görüşü şu şekildedir: “Aklınıza gelebilecek öğretim ilke ve yöntemleri içerisinde yer alan hemen her tekniğin kullanilabileceğini düşünüyorum. Tercih ettiğimi sorarsanız elbette yaratıcı drama." (U1). Burada tüm tekniklerin kullanılabileceği belirtilmekle birlikte uzmanın tercihinin yaratıcı drama olduğu görülmektedir. U2 de benzer şekilde pek çok yöntemin müzede sosyal bilgiler öğretiminde kullanılabileceğini ve yaratıcı drama yönteminin etkileyici olduğunu ifade etmiştir. "Birçok yöntem kullanılabilir ve yaratıcı drama bunlardan birisi ve çok etkileyici." (U2)

Sosyal bilgiler konularının müzede öğretimi sürecinde tüm yöntem ve tekniklerin kullanılabileceğini ifade eden 5 alan uzmanı bulunmaktadır. Uzmanlardan U3 görüşünü: “Öğrencinin aktif olduğu tüm yöntemler tercih edilebilir mesela istasyon, altı şapkalı düşünme tekniği de kullanabiliriz." (U3) şeklinde ifade etmiştir. Kullanılabilecek yöntem ve teknikler konusunda temel kriterin öğrencinin aktif olması olduğu anlaşılmaktadır. Yaratıcı drama da öğrenenin aktif ve merkezde olduğu yöntemler arasındadır.

Donuk imge tekniği uzmanlar tarafından en çok yer verilen teknikler arasındadır. Konu ile ilgili U5 "Meselâ donuk imge vardı kullandı̆̆ımız, bu tarih eğitiminde çok işe yarıyor müzelerde." (U5) ifadesinde bu tekniğin müzedeki uygulamalarda kullanışlı olduğunu belirtmektedir. Yaratıcı drama tekniklerinden donuk imgenin etkili oluşu konusunda "Yaratıcı dramanın pek çok tekniği var. Donuk imge meselâ müze etkinliklerinde etkili oluyor.” ifadelerini kullanmıştır (U7).U2 diğer tekniklerin kullanımı ile ilgili görüşünü: “...Diğer yöntemlerden gözlem, araştırma, yazma, çizme, nesneleri yeniden oluşturma, bunu bir sanat formuyla yeniden ortaya koyabilirsiniz. Ama ben etkili yöntemin yaratıcı dramanın olduğunu düşünüyorum." ş̧eklinde belirtmiştir. 


\section{Sosyal Bilgiler Dersi Kapsamında Yaratıcı Drama Yöntemi ile Müzede İşlenebilecek Konulara İlişkin Bulgular}

Müzede sosyal bilgiler öğretiminde yaratıcı dramanın bir yöntem olarak kullanılması sürecinde uzmanlar tarafından önerilen konulara ilişkin görüşler Tablo 3 ’te gösterilmiştir.

Tablo 3. Sosyal Bilgiler Dersi Kapsamında Yaratıcı Drama Yöntemi ile Müzede İşlenebilecek Konular

\begin{tabular}{llll}
\hline Konulara İlişkin İfadeler & Uzmanlar & $f$ & $\%$ \\
\hline Tüm konular & $\mathrm{U1,} \mathrm{U2,} \mathrm{U3,} \mathrm{U4,} \mathrm{U5,} \mathrm{U6,} \mathrm{U8,} \mathrm{U9,} \mathrm{U10,} \mathrm{U12}$ & 10 & 83,3 \\
\hline Müzenin çeşidine göre değişir. & $\mathrm{U} 7$ & 1 & $\% 8,3$ \\
\hline $\begin{array}{l}\text { Birçok konuda } \\
\text { (İnsanlar yerler çevreler, kültür ve miras, } \\
\text { bilim teknoloji ve toplum) }\end{array}$ & $\mathrm{U} 11$ & 1 & $\% 8,3$ \\
\hline
\end{tabular}

Tablo 3 incelendiğinde; sosyal bilgiler derslerinde tüm konuların yaratıcı drama yöntemi ile müzede işlenebileceğini 10 alan uzmanın belirttiği görülür $(f=10,83,3)$.Tüm konuların yaratıcı drama yöntemi ve müzeler için uygun olduğu belirtilirken, gerekçe olarak sosyal bilgiler dersinin disiplinlerarası bir yapıya sahip olduğu gösterilmiştir. Müzenin çeşidine göre bu konuların değişiklik gösterebileceğini 1 uzman belirtmiştir $(f=1, \% 8,3)$. Birçok konuda müzelerde uygulama yapılabileceği ifadesine ise 1 uzman yer vermiştir $(f=1, \% 8,3)$.

Sosyal bilgiler derslerindeki tüm konuların yaratıcı drama yöntemiyle müzede işlenebileceğine ilişkin U10 şu ifadeleri kullanmıştır; "Disiplinlerarası bir alan olduğu için her konuda uygulama yapmak mümkün.” (U10). Benzer şekilde tüm konuların yaratıcı drama yöntemi ile müzede işlenmek için uygun olduğuna yönelik U6 görüşünü “Tüm konular istisnasız müzede yaratıcı drama yöntemiyle işlenebilir. Çünkü sosyal bilgiler yapısı gereği disiplinlerarası bir yapıya sahiptir." (U6) şeklinde ifade etmiştir. Sosyal bilgiler dersinin disiplinlerarası bir yapıya sahip oluşu tüm konularda müzelerde yaratıcı drama yönteminden yararlanılabileceği konusunda temel gerekçeyi oluşturmaktadır.

Alan uzmanlarından U11 tüm konular ifadesi yerine birçok konuda yaratıcı drama yönteminden yararlanılabileceğini belirtmiştir. "İnsanlar, yerler, çevreler ögrenme alanı kapsamında coğrafi şekilleri gözlemleyip öğrenebilecekleri çalışmalar yapabilirler. Bilim ve teknoloji ve toplum ünitemiz var, teknolojinin zaman içindeki değişimini gösteren müzelere gidilebilir." (U11). Bilim teknoloji, coğrafya konuları, teknolojinin zaman içindeki değişimi örnek verilen bu konular arasindadir.

Alan uzmanlarından U7 sosyal bilgilerde yaratıcı drama yöntemi ile müzede işlenebilecek konuların müzenin çeşidine göre değiş̧ebileceğini belirtmiştir; "Bu müzenin çeşidine göre değişir. Arkeoloji müzesi ise Anadolu Uygarlıkları, Kurtuluş Savaşı müzesi ise inkılap tarihî konuları işlenebilir." (U7). Bu kapsamda örnek verilen müzeler arkeoloji müzeleri, Anadolu uygarlıkları ve Kurtuluş Savaşı temalı müzelerdir.

Alan uzmanlarının çoğu sosyal bilgiler öğretiminde tüm konuların yaratıcı drama yöntemi ile müzede işlenebileceğini belirtmiştir. Bu durum açıklanırken sosyal bilgiler derslerinin disiplinlerarası bir yapıda olması gerekçe gösterilmiştir. 


\section{Müzede Sosyal Bilgiler Öğretiminde Yaratıcı Drama Yönteminin Kullanımında Yaşanılan Sorunlara İlişskin Bulgular}

Alan uzmanlarının müzede sosyal bilgiler öğretiminde yaratıcı drama yönteminin kullanımı sürecinde yaşanan sorunlara yönelik görüşleri Tablo 4'te gösterilmiştir.

Tablo 4. Müzede Sosyal Bilgiler Öğretiminde Yaratıcı Drama Yönteminin Kullanımında Yaşanılan Sorunlar

\begin{tabular}{llll}
\hline Sorunlar & Uzmanlar & $f$ & $\%$ \\
\hline Öğretmenin yetersizliği & U1, U2, U6, U9, U10, U11, U12 & 7 & 58,3 \\
\hline Müze yetkililerin uygulamaya olumlu bakmamas1 & U2, U3, U5, U6, U9, U10 & 6 & 50 \\
\hline Ulaşım & U2, U3, U4, U5, U9, U11 & 6 & 50 \\
\hline Müzelerin uygulama yapmaya elverişli olmaması & U1, U3, U5, U6, U9 & 5 & 41,6 \\
\hline Bürokratik işlemler & U2, U3,U4, U11 & 4 & 33,3 \\
\hline Müfredatın yoğunluğu & U2, U7, U10, U11 & 4 & 33,3 \\
\hline Ekonomik sorunlar & U2, U9, U10, U11 & 4 & 33,3 \\
\hline Sinav kaygısı & U1, U2, U11 & 3 & 25 \\
\hline Gezinin plânlama sürecinin zorluğu & U2, U12 & 2 & 16,6 \\
\hline Farklı alanların müze kadrolarında yer almaması (tarih & U1,U5 & 2 & 16,6 \\
öğretmenliği, sosyal bilgiler öğretmenliği vd.) & & & \\
\hline Sosyal bilgiler ders saatinin yetersizliği & U7, U11 & 2 & 16,6 \\
\hline Kalabalık sinıflar & U10 & 1 & 8,3 \\
\hline Okul idaresine yüklenen sorumluluğun fazla olmas1 & U2 & 1 & 8,3 \\
\hline Öğretmenin sorumluluk almak istememesi & U4 & 1 & 8,3 \\
\hline İletişimsizlik & U5 & 1 & 8,3 \\
\hline
\end{tabular}

Tablo 4 incelendiğinde, müzede sosyal bilgiler öğretiminde yaratıcı drama yönteminin kullanılması sürecinde 12 uzmandan 7'si öğretmen donanımının yetersizliğini $(f=7, \% 58,3)$, 6's1 müze görevlilerinin uygulamaya olumlu bakmamasını müze uygulamaları sürecinde yaşanan sorunlar arasında belirtmiştir $(f=6, \% 50)$. Ulaşım, 6 uzman tarafından $(f=6, \% 50)$ belirtilen sorunlar arasındadır. Müzelerin uygulama için elverişli olmaması $5(f=5, \% 41,6)$, müfredatın yoğun oluşu, ekonomik problemler ve bürokratik işlemlerin uzun sürmesi ise her bir sorun maddesi için ayrı ayrı 4 alan uzmanı tarafindan ifade edilmiştir $(f=4, \% 33,3)$. 3 uzman sınav kaygısına yer verirken $(f=3$, \%25), gezi planlaması yapmanın zor oluşu, sosyal bilgiler ders saatlerinin yetersiz oluşu, müze kadrolarında tarih öğretmenliği gibi farklı branşlara yer verilmemesi sorunları 2 uzman tarafindan dile getirilmiştir $(f=2, \% 16,6)$. Ayrıca gezi sürecinde okul idaresine yüklenen sorumluluğun fazla oluşu, öğretmenlerin sorumluluk almak istemeyişi, sınıfların kalabalık oluşu 1 alan uzmanı tarafından belirtilen sorunlar arasındadir $(f=1, \% 8,3)$.

Alan uzmanlarından U11 sosyal bilgiler derslerinde müzelerden ve yaratıcı drama yönteminden faydalanma sürecinde yaşanan sorunların bir kısmına şu şekilde değinmiştir. "Ekonomik sorunlar, bürokratik sorunlar, ögretmenlerin yetersizliği, ulaşım problemleri, sınav kaygısı nedeniyle öğretmenlerin daha çok anlatıma yer vermesi, ders saatinin azlı̆̆l ve konuların fazlalı̆̆ı nedeniyle ögretmenlerin yaratıcı dramaya ayıracak enerjilerinin olmaması şeklinde sıralanabilir." (U11) 
Müze görevlilerinin müzelerde yapılan uygulamalara bakış açısı ve müze kadroları ile ilgili U5'in görüşleri şu şekildedir: "En büyük sorun müze yetkililerinin tavrı. ...Müze müdürleri ve müze eğitimcilerinin farklı branşlardan da olması taraftartyım Örneğin bir sosyal bilgiler öğretmeni bir tarih öğretmeni müze eğitiminde çalışabilir. Bir Tarih mezunu ya da bir tarih öğretmenliği mezunu neden müzede müdür olamıyor ben bunu anlayamıyorum." (U5)

\section{Müzede Sosyal Bilgiler Öğretiminde Yaratıcı Drama Yönteminin Kullanımında Yaşanılan Sorunların Çözümüne İlişsin Bulgular}

Alan uzmanlarının müzede sosyal bilgiler öğretiminde drama yönteminin kullanılmasında yaşanan sorunların çözümüne ilişkin görüşleri Tablo 5 'te gösterilmiştir.

Tablo 5. Müzede Sosyal Bilgiler Öğretiminde Yaratıcı Drama Yönteminin Kullanımında Yaşanılan Sorunlara Yönelik Çözüm Önerileri

\begin{tabular}{|c|c|c|c|}
\hline Öneriler & Uzmanlar & $\mathrm{f}$ & $\%$ \\
\hline Öğretmen eğitiminin verilmesi & U1, U2, U4, U6, U8, U11, U12 & 7 & 58,7 \\
\hline $\begin{array}{l}\text { Müzelerde yaratıcı drama gibi uygulama yapacak alanlar } \\
\text { açılması }\end{array}$ & U2, U3, U6, U9 & 4 & 33,3 \\
\hline Okul-müze arası ulaşım sorunun çözülmesi & $\mathrm{U} 2, \mathrm{U} 5, \mathrm{U} 10, \mathrm{U} 11$ & 4 & 33,3 \\
\hline Müze görevlilerinin eğitimi & U5, U6 & 2 & 16,6 \\
\hline İlgili kurumlar arasında protokoller imzalanması & U10, U11 & 2 & 16,6 \\
\hline $\begin{array}{l}\text { Sınav odaklı eğitim anlayışının değişip disiplinlerarası } \\
\text { anlayışın benimsenmesi }\end{array}$ & U1 & 1 & 8,3 \\
\hline Okullarda müze ve yaratıcı drama derslerinin olması & $\mathrm{U} 2$ & 1 & 8,3 \\
\hline $\begin{array}{l}\text { Müzelerde yapılan yaratıcı drama gibi uygulamaların } \\
\text { tanıtılması } \\
\text { ve paylaşılması }\end{array}$ & U4 & 1 & 8,3 \\
\hline $\begin{array}{l}\text { Okul ile okul dışı öğrenme mekânları arasında iletişimin } \\
\text { artması }\end{array}$ & U5 & 1 & 8,3 \\
\hline $\begin{array}{l}\text { Okul dışı geziler için sosyal bilgiler öğretmenlerinin görevli } \\
\text { olması }\end{array}$ & U7 & 1 & 8,3 \\
\hline Müzelerde imitasyon nesnelerin bulunması & U9 & 1 & 8,3 \\
\hline Uzmanların bir araya gelerek çözüm önerisinde bulunmaları & U10 & 1 & 8,3 \\
\hline $\begin{array}{l}\text { Öğretmenlere müzelerde yaratıcı drama gibi uygulamalar } \\
\text { için firsat verilmesi }\end{array}$ & U11 & 1 & 8,3 \\
\hline $\begin{array}{l}\text { Sosyal bilgiler öğretmenliğinin müze ve yaratıcı drama gibi } \\
\text { farklı yan dallardan eğitim alıp mezun olabilmeleri }\end{array}$ & $\mathrm{U} 1$ & 1 & 8,3 \\
\hline
\end{tabular}

Tablo 5 incelendiğinde; 12 uzmandan 7'si öğretmenlere hizmet içi eğitim verilmesi önerisinde bulunmuştur $(f=7, \% 58,3)$. 4 uzman müzelerin, yaratıcı drama gibi uygulama yapmaya uygun mekânlar olarak düzenlenmesini önermiştir $(f=4, \% 33,3)$. Okul müze arası ulaşım sorunun çözülmesi 4 uzman tarafından ifade edilmiştir $(f=4, \% 33,3)$. Proje tabanlı çalışmaların yapılmasını 3 uzman önermiştir $(f=3, \% 25)$. Müze görevlilerinin eğitimi önerisine 2 uzman yer vermiştir $(f=2$, \%16,6). İlgili kurumlar arasında protokollerin imzalanması yönünde 2 uzman görüş bildirmiştir $(f=2$, \%16,6). İfade edilen diğer çözüm önerileri; sınav odaklı eğitim anlayışının değişmesi, disiplinlerarası 
eğitim anlayışının benimsenmesi ( $f=1, \% 8,3)$, okullarda müze ve yaratıcı drama derslerinin olması $(f=1, \% 8,3)$, müzelerde yapılan uygulamaların tanıtım amaçlı paylaşımı $(f=1, \% 8,3)$ yönündedir. Okul ve okul dışı öğrenme mekânları arasındaki iletişimin arttırılması ( $f=1, \% 8,3)$, Sosyal bilgiler öğretmenlerinin gezilerde görevli olması $(f=1, \% 8,3)$, müzelerde nesnelerin imitasyonlarının bulundurulması $(f=1, \% 8,3)$ sunulan çözüm önerilerindendir. Son olarak alan uzmanlarının bir araya gelerek konu ile ilgili çözüm önerisi geliştirmeleri $(f=1, \% 8,3)$, öğretmenlere müzede uygulama firsatının verilmesi $(f=1, \% 8,3)$, sosyal bilgiler öğretmenliği programının müzede eğitim, yaratıc1 drama gibi farklı yan dallarda eğitim vermesi sunulan çözüm önerilerindendir $(f=1, \% 8,3)$.

Alan uzmanlarından U4 görüşünü "Öğretmen eğitimleri arttırllabilir. Tüm sosyal bilgiler ögretmenlerine bu alanda hizmet içi eğitim seminerleri verilebilir. Yapılan örnekler paylaşılabilir." (U4) şeklinde ifade etmiştir. U4, öğretmen eğitimlerinin arttırılmasını bir çözüm olarak sunarken, yaratıcı dramanın müzede kullanımına yönelik yapılan uygulamaların paylaşılmasını önermiştir. Öğretmen adaylarının eğitimine yönelik ise U1'in görüşleri şu şekildedir: "Artık tek bir alanın uzmanı değil de söz gelimi bakın şunu söylüyorum sosyal bilgiler ögretmeni adayları öğrenim görürken en az iki yan alandan daha mezun olmall. Yaratıcı drama olabilir, tarih, Türkçe olabilir, müzede eğitim olabilir gerekirse dört yılda değil altı yılda mezun olsun. Tek başına bir branş mezunu olmamalı iki yan alan daha yapmall. Ya da dört yılda mezun olduktan sonra kalan iki yılını o yan alanlarda uzmanlaşmak için meslek hayatına atıldıktan sonra da tamamlayabilsin. Yani böyle bir donanımla yetişmeli ögretmen. Ve bu disiplinlerarası yaklaşımın eğitim sistemleri içerisinde de doğrudan uygulamaya yönelik proje tabanlı çalışmaların daha fazla yapılması gerekiyor yani." (U1). Burada yalnızca ilgili konuda seminer ve derslerin verilmesi değil uzun vadede ve geniş kapsamlı bir eğitimin verilmesi önerisi söz konusudur.

Bir müzenin eğitim ortamı olarak kullanılabilmesi için uygulama yapılabilecek şartlara sahip olması önemlidir. Konu ile ilgili U9'un görüşleri şu şekildedir: “Müze sırasında çalışmalarda en büyük sıkıntıyı müzelere gittiğimizde eğitim faaliyetlerini yürütürken mekânlarda yaşlyoruz. Müzelerde çalışma salonları olmalı ve müzedeki nesnelerin imitasyonları bulunmalı. Bence her müzenin bir eğitim salonu olmalı ve bu imitasyonların burada kullanılması çok değerli diye düşünüyorum." (U9). Uzman, yaratıcı drama yöntemini müzede kullanırken mekânın buna elverişli olmamasının çalışmaları zorlaştırdığını ifade etmektedir. Bu sorunun çözümüne ilişkin olarak müzelerde uygulama yapılacak çalışma salonlarının ve imitasyon nesnelerinin bulunması önerisini sunmuştur.

Müzelerin eğitim amacıyla düzenlenmesinin yanı sıra müze çalışanlarının yaratıcı drama yöntemine ilişkin eğitim alması ve öğretmenlerin yönteme ilişkin bilgi ve becerilerini geliştirmeye yönelik çalışmaların yapılması da sunulan öneriler arasındadır. Alan uzmanlarından U6'nın konu ile ilgili görüşleri: “Öğretmenlerin yaratıcı drama yöntemine ilişkin bilgi ve beceri düzeyleri geliştirilmelidir, müze çalışanlarına yönelik eğitim verilebilir. Müzelerin alt yapısı buna hazırlanabilir. Müzede yaratıcı drama etkinliklerinin yapılması için alanlar ayrılmalıdır." (U6) şeklinde ifade edilmiştir.

U11 müzede sosyal bilgiler öğretiminde yaratıcı drama yönteminin kullanımında yaşanan sorunların çözümüne yönelik kurumlar arası işbirliğini önermiştir. "Ankara'da çok fazla müze var. Müzelerle, Turizm Bakanlı̆̆ ve MEB arasında protokol imzalanıp bürokratik işlemler kolaylaştırlabilir. Ekonomik anlamda sosyo-ekonomik olarak daha alt seviyedeki okullar için ulaşım için gerekli araçların temin edilmesi, teşvik edilmesi, yaratıcı drama ve müze eğitimi üzerine çalışan ögretmenlerin hem gönüllü hem profesyonel olarak en az her dönemde bir kez uygulama firsatı verilerek uygulamalar yapılabilir. Bu şekilde nasıl yapılacağına yönelik ögretmenler için bir farkındalı sağlanabilir ve uygulamaların devamı getirilebilir. 
Bence kurumlar arası projelendirme yapılarak hayata geçirilmeli diye düşünüyorum." U11'in bu görüşleri yalnızca kurumlar arası işbirliği ile sınırlı kalmayıp ilgili kurumlar arasında işbirliğine gidilmesini, okul ve müze arasında ulaşım araçlarının temin edilmesini, öğretmenlere yaratıcı drama ve müzede eğitim konusunda uygulama kolaylaştırıcı çalışmalar yapılmasını içermektedir. Ayrıca konu ile ilgili proje çalışmalarının yapılması sunulan öneriler arasındadır.

Alan uzmanları tarafından müzede sosyal bilgiler öğretiminde yaratıcı drama yönteminin kullanımında yaşanan sorunlara yönelik olarak; öğretmen eğitiminin verilmesi, müzelerde yaratıcı drama gibi uygulamaların yapılabileceği mekânların oluşturulması, müze görevlilerinin yaratıcı drama ve müze eğitimi konusunda eğitim alması, ilgili kurumlar arasında işbirliği yapılması, müze ve okul arasında ulaşımı sağlayabilecek servis araçlarının temin edilmesi sunulan öneriler arasındadır. Ayrıca okullarda müze ve yaratıcı drama derslerinin olması, müzelerde imitasyon nesnelerin bulundurulması, sosyal bilgiler öğretmen adaylarının yaratıcı drama ve müzede eğitim gibi farklı alanlarda yan dal eğitimi almaları önerilmiştir. Geliştirilen bu çözüm önerileri yalnızca müzede sosyal bilgiler öğretimini değil genel olarak sosyal bilgiler öğretimi, müzede eğitim ve yaratıcı drama uygulama süreçlerini ilgilendirmesi bakımından önemlidir.

\section{Tartışma, Sonuç ve Öneriler}

Alan uzmanlarının müzede sosyal bilgiler öğretiminde yöntem teknik kullanımına ilişkin görüşleri incelendiğinde, sıklıkla yaratıcı drama yöntemi ve tekniklerinin önerildiği ve bu teknikler arasında da en çok donuk imgeye yer verildiği sonucuna ulaşılmıştır. Sosyal bilgiler derslerinde müzelerin ve yaratıcı drama yönteminin kullanılması tavsiye edilmektedir. Sosyal bilgiler derslerinde müze ve yaratıcı drama yönteminin önemine yönelik sonuçlar Başbuğ ve Adıgüzel (2019) tarafindan yapılan araştırma sonuçları ile benzerlik göstermektedir. Başbuğ ve Adıgüzel (2019)'in çalışmalarında yaratıcı drama yönteminin müzede kullanılmasının sosyal bilgiler derslerinde akademik başarıyı arttırdığı ve etkili bir yöntem olarak konulara ilişkin farkındalık kazandırdığı belirtilmektedir. Oruç ve Altın (2008)'ın müze eğitimi ve yaratıcı drama konulu çalışmalarında da müzede eğitim süreçlerinde yöntem olarak yaratıcı dramanın etkin şekilde kullanılabilecek yöntemler arasında olduğu ifade edilmektedir. Uzman görüşlerinden ulaşılan bulgular ile ilgili alan yazındaki çalışmaların birbirini desteklediği görülmektedir. Bu bilgiler doğrultusunda, müzede sosyal bilgiler öğretiminde yaratıc1 drama yönteminin kullanımının birçok açıdan önemli ve gerekli olduğu söylenebilir.

Alan uzmanları sosyal bilgiler derslerinde genel olarak tüm konuların yaratıcı drama yöntemi ile müzede işlenmek için uygun olduğunu belirtmişlerdir. Ay ve Fidan (2014) sosyal bilgiler derslerinde müze kullanımını inceledikleri çalışmalarında, öğretmen adaylarının sosyal bilgiler derslerinin müze kullanımı için en uygun derslerden biri olduğu yönünde görüş bildirdiklerini belirtmişlerdir. Güven (2010)'in sosyal bilgiler derslerinde yaratıcı dramanın kullanımı incelediği çalışmada, yaratıcı drama yönteminin sosyal bilgiler derslerinde faydalı ve gerekli olduğu belirtilmiştir. Yaratıcı drama yöntemi sosyal bilgiler derslerinde müzelerden yararlanırken etkin şekilde kullanılabilecek yöntemler arasında olduğuna vurgu yapmıştır. 
Müzede sosyal bilgiler öğretiminde yaratıcı drama yöntemi kullanılırken yaşanan sorunlar; öğretmen donanımının yetersizliği, müze görevlilerinin uygulamalı çalışmalara olumlu bakmaması ve ulaşım konusudur. Ayrıca müze ortamlarının uygulamalı eğitim faaliyetleri için uygun olmayışı, ders müfredatının yoğun oluşu, ekonomik problemler ve bürokratik işlemlerin uzun sürmesi belirtilen diğer sorunlar arasındadır. Metinnam, Keleşoğlu ve Özen (2014)'in araştırmalarında, sosyal bilgiler öğretmenlerinin yaratıcı drama yöntemini yeterli düzeyde kullanmadıkları ve uygulamada sorun yaşadıkları belirtilmektedir. Hamurculu (2016) yaratıcı drama yönteminin müzede kullanımını incelediği çalışmasında; öğretmenlerin müze ziyaretlerine hazırlıksız geldikleri sonucuna ulaşmıştır. İlgili alan yazın incelendiğinde öğretmen donanımındaki yetersizlik, müfredat yoğunluğu gibi sorunların Koç (2013)'un çalışma sonuçları ile benzerlik gösterdiği görülmektedir. Koç (2013) sosyal bilgiler ve sınıf öğretmenlerinin görüşlerini aldığı çalışmasında yaratıcı dramaya ilişkin bilgi eksikliği, müfredatın yetiştirilememesi, araç gereç eksikliği, yaratıcı drama yönteminin etkili şekilde uygulanamaması gibi sorunların yaşandığı sonucuna ulaşmıştır. Yaşanan ulaşım problemi ile ilgili olarak Alataş (2008)'ın sosyal bilgiler öğretmenleri ile yaptığı bir çalışmada öğretmenlerin \%83'ü okula ulaşım ve barınma konusunda sorun yaşadığı belirlenmiştir. Dolayısıyla öğretmen yeterliliğinin ve okul dışı mekânlarda eğitim faaliyetlerinin arttırılması tartış1lırken öğretmenlerin barınma ve okula ulaşım problemi yaşamaları önemli bir bulgudur. Ev ile okul, okul ile müze arasındaki ulaşım araçlarının temin edilerek ulaşımın kolaylaştırılması bu noktada önem kazanmaktadır.

Araştırma sonuçları genel olarak incelendiğinde sosyal bilgiler öğretiminde müzelerden yararlanırken kullanılması önerilen yöntem ve tekniklerin başında yaratıcı drama yöntemi ve teknikleri gelmektedir. Müze ortamlarında, sosyal bilgiler derslerine ilişkin konuların yaratıcı drama yöntemi ile disiplinlerarasındaki benzerliklerden dolayı kolaylıkla işlenebileceği sonucuna ulaşılmıştır. Yaratıcı drama yolu ile müzede sosyal bilgiler öğretimi sürecinde dile getirilen sorunların başında öğretmen donanımının yetersizliği, uygulama etkinliklerine ilişkin müze yetkililerinin olumsuz bakışı ve müze ile okul arasında yaşanan ulaşım güçlüğü gelmektedir.

Ulaşılan sonuçlar, yaratıcı drama yolu ile müzede sosyal bilgiler öğretimi kapsamında olsa da genel olarak tüm sosyal bilgiler öğretimi süreçlerini, müzede eğitim ve yaratıcı drama yönteminin uygulama süreçlerini ilgilendirmektedir. Bir sosyal bilgiler öğretmeninin müze gezisi için ulaşım arac1 temin edememesi okuldaki tarih, coğrafya, edebiyat gibi diğer branşlar için de geçerli bir konudur. Bir müzede yetkililerin uygulamalı eğitim faaliyetlerine izin vermemesi, o müzede uygulama yapmay1 plânlayan her branştan eğitimciyi ilgilendirmektedir. Bu nedenle ulaşılan sonuçlara yönelik getirilen çözüm önerileri daha geniş bir çerçeve ile tüm sosyal bilgiler, yaratıcı drama ve müzede öğrenme çalışmalarıyla ilişkili olarak da değerlendirilmelidir.

Araştırmada ulaşılan sonuçlar dikkate alınarak müzede sosyal bilgiler öğretiminde yaratıcı drama yönteminin kullanımı ile ilgili bir takım öneriler geliştirilmiştir. Bu doğrultuda araştırma sonunda şu öneriler sunulmaktadır: Öğretmen adaylarının staj yerleri okullarla sınırlandırılmayıp, Kültür Bakanlığı, Millî Eğitim Bakanlığı ve üniversiteler arasında işbirliği yapılarak öğretmen stajlarının müzeler gibi okul dışı öğrenme ortamlarında ve Çağdaş Drama Derneği gibi yaratıcı drama eğitimi veren kurumlarda gerçekleştirilmesine olanak tanınabilir. MEB müze ziyareti takip sistemi oluşturarak müze ziyareti çalışmalarının takibini yapabilir ve en çok ziyaret yapan okulla bu kapsamda teşvik edici çalışmalar yürütülebilir. Müze görevlilerine müzede öğrenme ve yaratıc1 drama konusunda uygulamalı eğitimler verilebilir. Müzelerde, yaratıcı drama gibi uygulamalı 
çalışmalar yapılabilecek alanlar oluşturulabilir. Belediyeler, okul-müze arası ulaşım araçlarının temin edilmesi konusunda Millî Eğitim Bakanlığı ile iş birliği yapabilir. Müzelerin eğitim ortamı olarak kullanılması ve müzelerdeki yaratıcı drama çalışmalarına yönelik tanıtım ve farkındalık çalışmaları sosyal medya yolu ile sağlanabilir. Ortak etiketler (hashtag) ile müzelerde yapılan çalışmaların duyuruları yapılabilir. MEB müzede eğitim ya da yaratıcı dramanın müzede kullanımı konusundaki farkındalığı artırmak için bu konuyla ilgili paylaşımları, yarışmaları ve çalışmaları sosyal medyadan yürütebilir. Müzede eğitim ve yaratıcı drama alanlarında çalışan uygulayıcılar yaptıkları çalışmaları projelendirerek onları uluslararası eğitim platformlarına taşıyabilirler. 


\section{Kaynakça}

Alataş, F. (2008). Illköğretim programında 4. ve 5. sinıf sosyal bilgiler ögrretiminde karşılaşılan sorunlar. Yüksek Lisans Tezi. Dokuz Eylül Üniversitesi Eğitim Bilimleri Enstitüsü, İzmir. https://tez.yok.gov.tr/UlusalTezMerkezi/tezSorguSonucYeni.jsp sayfasından erişilmiştir.

Akyüz, G. (2009). Sanayi müzelerinin tarih eğitiminde kullanım durumu: rahmi koç müzesi örneği. Yayımlanmamış yüksek lisans tezi. Marmara Üniversitesi Eğitim Bilimleri Enstitüsü, İstanbul.

Ay, S. \& Fidan, N. (2014). Öğretmen adaylarının sosyal bilgiler dersinde müzelerden yararlanmaya ilişkin görüşleri. Sosyal Bilimler Dergisi, 48 (48), 69-89. dergipark.ulakbim.gov.tr/esosder/article/viev/5000068665 sayfasından erişilmiştir.

Aykaç, M. (2008). Sosyal bilgiler dersinde yaratıcı dramanın yöntem olarak kullanılmasının ögrenci başarısina etkisi. Yayımlanmamış yüksek lisans tezi. Ankara Üniversitesi Eğitim Bilimleri Enstitüsü, Ankara.

Başbuğ, S. \& Adıgüzel, Ö. (2019). Müzede yaratıcı drama etkinliklerinin öğrencilerin sosyal bilgiler dersindeki başarılarına etkisi. Yaratıcı Drama Dergisi, 14 (1), 1-32.

Başbuğ, S. (2017). Müzede yaratıcı drama yönteminin sosyal bilgiler dersindeki ögrencilerin başarısına etkisi. Yayımlanmamış yüksek lisans tezi. Ankara Üniversitesi, Eğitim Bilimleri Enstitüsü, Ankara.

Büyüköztürk, Ş. (2012). Örnekleme yöntemleri. http://w3.balikesir.edu.tr/ msackes/wp/wp-content/uploads/2012/03/BAY-Final-Konulari.pdf sayfasından erişilmiştir.

Creswell, J.W. (2016). Nitel araştırma yöntemleri beş yaklaşıma göre nitel araştırma ve deseni. (Çev. M. Bütün, S. B. Demir). Ankara: Siyasal. (Orijinal çeviri tarihi, 2013).

Çetin, M. (2014) Sosyal bilgiler öğretmen adaylarının eğitiminde müze ortamının kullanılması. Yayımlanmamış yüksek lisans tezi. Akdeniz Üniversitesi Eğitim Bilimleri Enstitüsü, Antalya.

Güler, A. (2019). Müzede eğitim öğrenme ortamı olarak müzeler. Buyurgan, S. (Ed.). Müzecilik ve müzede eğitimin tarihsel gelişimi içinde (s.59-87). Ankara: Pegem.

Güler, A., Hacıoğlu \& M.B., Taşğın, S. (2015). Sosyal bilimlerde nitel araştırma. Ankara: Seçkin.

Güven, A. (2010). İlköğretim okulları sosyal bilgiler dersindeki tarih konularında yaratıcı drama kullanımı. Atatürk Üniversitesi Kazım Karabekir Eğitim Fakültesi Dergisi, 0 (11), 454-461. http://dergipark.gov.tr/ ataunikkefd/issue/2772/37112 sayfasından erişilmiştir.

Hamurculu, Ü. H. (2016). Ankara'daki müzelerde yaratıcı drama etkinlikleri ve Ankara resim heykel müzesinde yaratıcı drama önerisi. Yayımlanmamış yüksek lisans tezi. Ankara Üniversitesi Sosyal Bilimler Enstitüsü, Ankara.

Hooper-Greenhill, E. (1999). Müze ve galeri eğitimi (M. Ö. Evren \& E. G. Kapçı, Çev.). Ankara: Çocuk Kültürü Araştırma ve Uygulama Merkezi.

Koç, İ. (2013) Öğretmenlerin sosyal bilgiler dersinde drama yöntemini uygulama ve drama tekniklerine ilişkin yeterliliklerinin belirlenmesi. Yayımlanmamış yüksek lisans tezi. Ahi Evran Üniversitesi Sosyal Bilimler Enstitüsü, Kırşehir.

Marriam, B. S. (2016). Nitel araştırma desen ve uygulama için bir rehber. (Çev. Turan, S.). Ankara: Nobel. (Orijinal çeviri tarihi, 2013)

Metinnam, İ. \& Keleşoğlu, S. \& Özen, Z. (2014). Sosyal bilgiler eğitiminde yaratıcı dramanın bir yöntem olarak kullanılmasına ilişkin öğretmen görüşleri. Journal of Education and Future, 0 (6), 43-58. http:// dergipark.gov.tr/jef/issue/18638/196719 sayfasından erişilmiştir.

Milli Eğitim Bakanlığı. (2004). İlköğretim 1-8. sınıflar türkçe, matematik, sosyal bilgiler, hayat bilgisi ile fen ve teknoloji dersi öğretim programlarında müze ile eğitim. Ankara: MEB.

Onur, B. (2013). Müze ve oyun kültürü. Ankara: İmge.

Oruç, S. \& Altın, B. N. (2008). Müze eğitimi ve yaratıcı drama. Çukurova Üniversitesi Eğitim Fakültesi Dergisi, 3 (35), 125-141. http://www.acarindex.com/dosyalar/ makale/acarindex-1423874898.pdf sayfasindan erişilmiştir. 
Ödekan, A. \& Tezcan Akmehmet, K. (2006). Müze eğitiminin tarihsel gelişimi. İTÜ Dergisi, 3(1), 47-58. http://www.itudergi.itu.edu.tr/index.php/itudergisi_b/article/view/1085 sayfasından erişilmiştir.

San, İ. (2018). Yaratıcı drama ve müze. M. Akoğuz (Ed.) Müze eğitim bilimi nasıl gelişti içinde (s. 220-231). İstanbul: Yeni İnsan.

Turgut, G. (2015) Sosyal bilgiler dersinde bir eğitim aracı olarak sanal müze kullanımı. Yüksek Lisans Tezi. Adnan Menderes Üniversitesi Sosyal Bilimler Enstitüsü, Aydın.

Yıldırım, A. \& Şimşek, H. (2003) Sosyal bilimlerde nitel araştırma yöntemleri, Ankara: Seçkin.

Yıldırım, A. (2006). Sosyal bilimlerde nitel araştırma yöntemleri. Ankara: Seçkin.

Yıldırım, K. (2010). Nitel araştırmalarda niteliği artırma. Illköğretim Online, 9 (1). https://scholar.google.com/ scholar?hl=tr\&as_sdt=0\%2C5\&q="Yıldırım"+"Geçerlik"\&btnG= sayfasından erişilmiştir. 


\begin{tabular}{rr} 
çağdaş & Yaratıcı Drama Dergisi 2019, 14(2), 281-296 \\
drama & www.yader.org \\
\hline
\end{tabular}

\section{Çocuk ve Drama Dersi Veren Öğretim Elemanlarının Niteliklerine İlişkin Çocuk Gelişimi Programı Öğrencilerinin Görüşleri}

\section{Ömer Nayci ${ }^{1}$}

\begin{tabular}{|c|c|}
\hline Makale Bilgisi & $\ddot{\mathbf{O} z}$ \\
\hline DOI: $10.21612 /$ yader.2019.016 & Bu çalışmada üniversitelerin meslekyüksekokulları bünyesindeyer alan Çocuk Gelişimi \\
\hline Makale Geçmişi & $\begin{array}{l}\text { Programında ogrenım goren ogrencilerın almış olduklarl çocuk ve drama dersını } \\
\text { veren öğretim elemanlarının niteliklerine ilişkin öğrenci görüşlerinin belirlenmesi }\end{array}$ \\
\hline Geliş tarihi & amaçlanmıştır. Araştırma tarama türünde nitel bir araştırmadır. Araştırmanın çalışma \\
\hline 12.07.2019 & $\begin{array}{l}\text { grubunu 2018-2019 ĕ̆itim öğretim yılında üniversitelerin meslek yüksekokulları } \\
\text { Çocuk Geliş̧imi Programlarında ögrenim gören, çocukve drama dersi alan ögrenciler } \\
\text { oluşturmuştur. Araştırma kapsamında Siirt Üniversitesi’nden } 16 \text { ögrenci, Mardin }\end{array}$ \\
\hline Anahtar Sözcükler & Artuklu Üniversitesi'nden 13 öğrenci, Batman Üniversitesi'nden 28 ögrenci ve Şırnak \\
\hline Öğretim elemanı & Üniversitesi'nden 37 öğrenci olmak üzere toplam 94 öğrenciden görüş alınmıştır. \\
\hline Çocuk ve drama dersi & $\begin{array}{l}\text { Araştırmada veri toplama aracı olarak görüşme formu kullanılmıştır. Bu form } \\
\text { araştırmacı tarafindan hazırlanmış olup, bir açık uçlu sorudan oluşturulmuştur. }\end{array}$ \\
\hline Nitelik & Araştırma sonucunda elde edilen veriler, içerik analizi ile analiz edilmiştir. Çocuk \\
\hline Çocuk gelişimi programı & $\begin{array}{l}\text { Gelişimi Programında öğrenim gören öğrenciler tarafindan çocuk ve drama dersini } \\
\text { veren ögretim elemanlarının niteliklerine ilişkin olarak ortak temalar dişında en çok }\end{array}$ \\
\hline Makale Türü & vurgulanan nitelikler; öğretim elemanının ĕ̆lenceli bir kişiliğe sahip olması, yeniliğe \\
\hline Araştırma Makalesi & 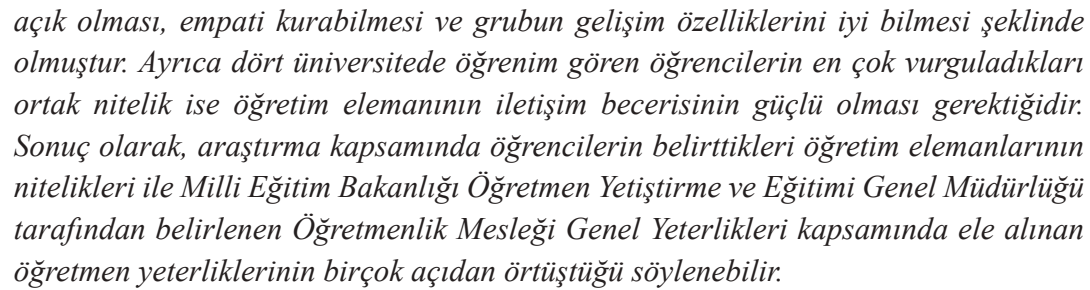 \\
\hline
\end{tabular}

1 Dr. Öğr. Üy., Sırnak Üniversitesi, Sırnak MYO, Sırnak, Türkiye. E-posta: nayciomer@gmail.com Orcid ID: https://orcid.org/0000-0002-6087-6456 


\title{
The Opinions of Child Development Programme Students Related to the Qualifications of Instructors Teaching Child and Drama Lesson
}

\begin{tabular}{lr}
\hline Article Info \\
\hline DOI: $10.21612 /$ yader.2019.016 \\
\hline Article History & \\
Received & 02.06 .2019 \\
Accepted & 12.07 .2019
\end{tabular}

\begin{abstract}
In this study, it is aimed to determine the student opinions of the students studying in Child Development Programme within the scope of vocational schools of universities related to the qualifications of instructors teaching Child and Drama lesson. The study is a qualitative research in the type of a survey. The students taking Child and Drama lesson who study in Child Development Programmes in the vocational schools of universities in 2018-2019 academic year formed the study group of the study. The opinions of 94 students were taken in total within the scope of this study;16 of them were from Siirt University, 13 from Mardin Artuklu University, 28 from Batman University and 37 from Shirnak University. Interview form was used in the study as data collection tool. This form was prepared by the researcher and it consists of one open ended question. The data obtained in consequence of the research was analysed with content analysis. The most emphasised qualifications as the qualifications of instructors teaching Child and Drama lesson emphasised by the students studying in Child Development Programme except the common themes were insructor having an entertaining personality, being open to new ideas, showing emphaty and knowing the development features of the group well. Besides, the most common qualification emphasised by the students studying in four universities was the communication skill of the instructor being strong. As a result, it can be said that the qualifications of instructors specified by the students within the scope of the research coincide in many aspects with instructor qualifications specified within the scope of Teaching Profession General Qualifications which were determined by Ministry of National Education General Directorate of Teacher Training and Education.
\end{abstract} Keywords

Instructor

Child and drama lesson, Qualification

Child development programme

Article Type

Research paper 


\section{Giriş}

Ülkelerin uygulamış oldukları eğitim sistemlerinin tarihsel süreç içerisinde ihtiyaca cevap verip vermediği sürekli tartışma konusu olmuştur. Hızlı gelişen teknoloji, toplumsal dinamiklerde birtakım değişiklilikleri de beraberinde getirmiştir. Söz konusu değişen koşullara bağlı olarak toplumun bireyden beklentileri de değişmiştir. Dolayısıyla toplum tarafindan nasıl bir birey istenildiği sorusunun yanıtlanması ihtiyacı ortaya çıkmıştır. Bu soruya bağlı olarak bireyi yetiştiren ve topluma kazandıran öğretmenin niteliği de tartışılmaya başlanmıştır. Bu durum da "Nasıl bir birey?" sorusunun yanı sıra "Nasıl bir öğretmen?" sorusunu da beraberinde getirmiştir. Bu soruya bağlı olarak öğretmenin niteliği, toplumu oluşturan temel bileşenlerin değişimiyle eşzamanlı olarak tartışılan bir konu olmuştur. Öğretmenin nitelik olarak kendisinden beklenilenleri yerine getirdiği varsayıldığında, bireyin yaşama dönük anlamlı bilgiyi yapılandırdığg öğrenme öğretme sürecinin de verimli geçmesi sağlanacaktır.

Özetle, eğitim ve öğretimin bütün boyutlarıyla dinamik bir yapıya sahip olması, bu süreçte önemli bir rol üstlenen öğretmenin görevinin ve bu görevin gerektirdiği niteliklerin sürekli sorgulanmasını ve geliştirilmesini gerekli kılar. Bu nedenle Millî Eğitim Bakanlığı’nın üniversitelerle işbirliği yaparak, öğretmen yeterlikleri üzerine yürüttüğü çalışmalar süreklilik göstermektedir (MEB, 2006).

Öğretmen yeterlikleri ile ilgili Millî Eğitim Bakanlığı ve üniversitelerin işbirliği içersinde çalışmalar yapılmış olsa da öğretim elemanlarının yeterlikleri ile ilgili çalışmaların sınırlı düzeyde kaldığı söylenebilir. Özellikle son yıllarda uygulamaya konulan öğretim programlarının dayandığ1 öğrenme ve öğretme yaklaşımları açısından önemi birçok bilimsel çalışma ile ortaya konulan yaratıcı dramanın uygulayıcıları olan öğretmenlerle ilgili bazı çalışmalar yapılmış olsa da öğretim elemanlarının yeterlikleri ile olarak ilgili alanyazında yeterli çalışmanın olmadığı görülmüştür.

Bir eğitim sisteminin bir öğretmenden beklediği özelliklerin tamamı, bir yaratıcı drama eğitmeninden de beklenir (Adıgüzel, 2018). Dolayısıyla üniversitelerde okutulan yaratıcı drama derslerini vermekle sorumlu olan öğretim elemanlarının yeterlikleri ile öğretmenlerin yeterliklerinin benzer olduğu söylenebilir.

Yaratıcı drama eğitmeni, drama çalışmalarında katılımcılara rehberlik edendir. Bu alanda süreci tasarlayan, biçimlendiren, yöneten eğitmen-öğretmen kavramından yaratıcı drama süreçlerine hakim, kuramsal ve uygulamalı çalışmalarda yeterli, uygulama becerisi de olan ya da aynı süreçleri bildiği halde farklı bir alanda uzman olan, yaratıcı dramayı bir yöntem olarak kendi alanında kullanan öğretmen anlaşılmalıdır (Adıgüzel, 2018). Dolayısıyla eğitimin hangi kademesinde olursa olsun bir yaratıcı drama eğitmeninden beklenilen birtakım yeterlikler söz konusudur.

Bir yöntem, yalnızca o yöntemi kullanan kişi kadar iyidir (McCaslin, 2006/2016, s.277). Başka bir deyişle yöntemin etkililiği, yöntemin uygulayıcısı olan öğretmen ya da eğitmenlerin mesleki yeterliliği ile ilişkilidir. Yaratıcı drama öğretmeninin kişisel ve mesleki açıdan çeşitli özelliklere sahip olmaları beklenir. Kişisel özelliklerin ya da sahip olunması gereken temel değerlerin arasında; insanı sevme, saygılı olma, kendisine güvenme, yaratıcı düşünme, özgün olma, sabırlı davranma, farklı görüşleri dikkate alma, hızlı düşünme, karar verme, çevresine örnek olma, empati kurma, öğrenmeye istekli olma, gelişmeye açık olma, bilimsel düşünmeye saygılı olma vb. sayılabilir. Drama öğretmeninin mesleki özellikleri ise genel kültür birikimi, alan bilgisi ve drama öğretmenliği becerilerinden oluşur (Üstündağ, 2009). 
Alanyazında daha çok yöntem boyutuyla ön plana çıkan yaratıcı drama aynı zamanda kendi amaçları ve içeriği olan, belirli öğrenme kuramlarına dayanan ya da bu kuramlarla ilişkili olan, kendine özgü ölçme ve değerlendirme yaklaşımlarına sahip bağımsız bir ders olma özelliğine sahiptir (Adıgüzel, 2018). Dolaysıyla kendine özgü bir yapıya sahip olan dramanın uygulayıcısı olan öğretmenlerin, eğitmenlerin ya da öğretim elemanlarının da çeşitli yeterliklere sahip olmaları gerekir. Söz konusu bu yeterlikler hızla değişen toplum dinamiklerine bağlı olarak çeşitlenebilir ya da artabilir. Dolayısıyla farklı zaman dilimlerinde drama eğitimi verecek olan eğitimcilerden beklentiler de değişebilir.

Drama eğitmenlerinden beklentilerin ya da drama eğitmenlerinin sahip olmaları gereken özelliklerin günümüz koşullarında hangi çerçevede ve hangi noktalarda yoğunlaştığını belirlemek bu araştırmanın önemini arttırmıştır. Başka bir deyişle drama öğretmenlerinin yeterlikleri ile ilgili daha önce birtakım çalışmalar yapılmış olsa da söz konusu çalışmaların sınırlı kaldığı ve daha güncel çalışmalara ihtiyaç duyulduğu söylenebilir. Ayrıca alanyazın incelendiğinde, Kasapoğlu(2019), Çetingöz (2012), Kara (2014), Okvuran (2003) ve Tutuman (2011) tarafindan daha önce yapılan çalışmaların genellikle öğretmen ya da drama eğitimi alan bireylerin yeterliklerini belirlemekle sınırlı kaldığı görülmüştür. Ancak bu araştırmanın üniversitelerde bu alanda eğitim veren öğretim elemanlarının yeterlikleriyle ilgili olması nedeniyle özgün bir araştırma olduğu söylenebilir.

$\mathrm{Bu}$ araştırmada "Çocuk gelişimi programı öğrencilerinin görüşlerine göre çocuk ve drama dersini veren öğretim elemanlarının nitelikleri nasıl olmadır?” sorusuna yanıt aranmıştır.

\section{Araştırmanın Amacı}

$\mathrm{Bu}$ araştırmanın amacı; üniversitelerin meslek yüksekokulları bünyesinde yer alan Çocuk Gelişimi Programında öğrenim gören öğrencilerin almış oldukları çocuk ve drama dersini veren öğretim elemanlarının niteliklerine ilişkin öğrenci görüşlerini belirleyip değerlendirmektir.

\section{Yöntem}

\section{Araştırma Modeli}

$\mathrm{Bu}$ araştırma, çocuk ve drama dersi veren öğretim elemanlarının niteliklerine ilişkin Çocuk Gelişimi Programı öğrencilerinin görüşlerini belirlemek amacıyla tarama türünde nitel bir araştırmadır. Nitel araştırma, gözlem, görüşme ve doküman analizi gibi nitel veri toplama yöntemlerinin kullanıldığı, algıların ve olayların doğal ortamda gerçekçi ve bütüncül bir biçimde ortaya konmasına yönelik nitel bir sürecin izlendiği araştırma olarak tanımlanabilir (Yıldırım ve Şimşek, 2013). Tarama modelleri ise geçmişte ya da halen var olan bir durumu var olduğu şekliyle betimlemeyi amaçlayan araştırma yaklaşımlarıdır. Araştırmaya konu olan olay, birey ya da nesne, kendi koşulları içinde ve olduğu gibi tanımlanmaya çalışılır (Karasar, 2015). Araştırmanın amacına en uygun desen olması nedeniyle araştırma tarama modeline göre desenlenmiştir.

\section{Çalışma Grubu}

Araştırmanın çalışma grubunu 2018-2019 eğitim öğretim yılında üniversitelerin meslek yüksekokulları Çocuk Gelişimi Programlarında öğrenim gören, çocuk ve drama dersi alan öğrenciler oluşturmuştur. Çalışma grubuamaçl1örnekleme yöntemiyle belirlenmiştir. Amaçlıörnekleme, olasılıklı 
ve seçkisiz olmayan bir örnekleme yaklaşımı olup, çalışmanın amacına bağlı olarak bilgi açısından zengin durumların seçilerek derinlemesine araştırma yapılmasına olanak tanır (Büyüköztürk ve diğ., 2009). Araştırma kapsamında Siirt Üniversitesi’nden 16 öğrenci, Mardin Artuklu Üniversitesi’nden 13 öğrenci, Batman Üniversitesi'nden 28 öğrenci ve Şırnak Üniversitesi’nden 37 öğrenci olmak üzere toplam 94 öğrenciden görüş alınmıştır. Böylece farklı üniversitelerde aynı dersi alan ve sosyokültürel olarak benzerlik gösteren illerde öğrenim gören öğrencilerin görüşleri arasındaki benzerlik ve farklı1ıkları ortaya koymak amacıyla çalışma gurubu belirlenmiştir.

\section{Veri Toplama Araçları}

Araştırmada veri toplama aracı olarak araştırmacı tarafından hazırlanan ve bir açık uçlu sorudan oluşan görüşme formu kullanılmıştır. Görüşme formu hazırlanırken eğitim programları ve öğretimi ile yaratıcı drama alanında uzman kişilerden görüş alınmış, ardından görüşme formu 4 öğrenciye uygulanmış ve gerekli düzeltmeler yapılarak forma son şekli verilmiştir. Daha sonra çalışma grubunda yer alan öğrencilere; "Sizce drama dersi veren bir öğretim elemanının sahip olması gereken nitelikler nelerdir?” sorusu yöneltilmiştir.

\section{Verilerin Toplanması}

Araştırma kapsamında dört farklı üniversitenin Çocuk Gelişimi Programlarında öğrenim gören, çocuk ve drama dersi alan öğrencilere görüşme formu uygulanmış ve öğrencilerin görüşleri yazılı olarak alınmıştır.

\section{Verilerin Analizi}

Araştırmadan elde edilen verilere içerik analizi yapılmıştır. İçerik analizi, hacimli olan nitel materyali, temel tutarlılıkları ve anlamları belirlemeye yönelik olarak herhangi bir nitel veri indirgeme ve anlamlandırma çabası girişimi olarak tanımlanır (Patton, 2002/2014, s.453). Diğer bir ifadeyle belirli kurallara dayalı olarak kodlamalarla bir metnin bazı sözcüklerinin daha küçük içerik kategorileri ile özetlendiği sistematik, yinelenebilir bir tekniktir (Büyüköztürk ve diğ., 2009, s. 284). Söz konusu analiz sürecinde asıl amaç toplanan verileri açıklayabilecek kavramlara ve kavramlar arası ilişkilere ulaşmaktır (Yıldırım ve Şimşek, 2013, s.259). Buna göre farklı üniversitelerde öğrenim gören öğrencilerin yaratıcı drama derslerini vermekle sorumlu olan öğretim elemanlarının sahip olmaları gereken niteliklere ilişkin elde edilen veriler doğrultusunda araştırmacı tarafindan her bir üniversite için temalar ve buna bağlı alt temalar belirlenmiştir. Başka bir alan uzmanı tarafından da aynı veriler incelenmiş ve aynı şekilde temalar ve buna bağlı alt temalar belirlenmiştir. Bunun sonucunda öğretim elemanlarının niteliğine ilişkin olarak kişisel ve mesleki nitelikler olmak üzere iki tema belirlenmiş ve alt temalar bu başlıklar altında toplanmıştır. Temaların belirlenmesi sürecinde görüş birliği ve görüş ayrılığı olan durumlar tartışılmış ve temalara son şekli verilmiştir. Bu süreçte görüş birliği ve görüş ayrılı̆̆ 1 yaşanan konularda iki araştırmacı arasındaki tutarlılığın hesaplanmasında Miles ve Huberman'ın (1994) görüş birliği formülü [P=(görüş birliği/ görüş birliği+görüş ayrılı̆̆ı)x100] kullanılmıştır. Bunun sonucunda iki araştırmacı arasındaki görüş birliğine ilişkin güvenirlik katsayısı \%79.3 olarak bulunmuştur. Miles ve Huberman (1994)'a göre kodlayıcılar arasındaki güvenirlik katsayısı \%70'in üzerindeki değerler ölçüt alındığından elde edilen katsayıya göre araştırma verilerinin güvenilir olduğu kabul edilmiştir. 


\section{Bulgular}

Bu bölümde Batman, Mardin Artuklu, Siirt ve Şırnak Üniversitelerinin Çocuk Gelişimi Programında öğrenim gören öğrencilerin Çocuk ve Drama dersini veren öğretim elemanlarının niteliklerine ilişkin öğrenci görüşleri her bir üniversite açısından ayrı ayrı ele alınmış, daha sonra dört farklı üniversitede öğrenim gören öğrencilerin öğretim elemanlarının niteliklerine ilişkin belirttikleri ortak ifadelere yer verilmiştir. Araştırma bulguları bu alt başlıklar altında sunulmuştur.

Araştırma kapsamında, Batman Üniversitesi Çocuk Gelişimi Programında öğrenim gören öğrencilerin çocuk ve drama dersini veren öğretim elemanlarının niteliklerine ilişkin görüşleri Tablo 1 'de verilmiştir.

Tablo 1. Batman Üniversitesi’nde Öğrenim Gören Öğrencilerin Öğretim Elemanlarının Niteliklerine Illişkin Görüşleri

\begin{tabular}{|c|c|c|c|}
\hline Temalar & Alt Temalar & f & $\%$ \\
\hline \multirow{9}{*}{ Kişisel Nitelikler } & Eğlenceli bir kişiliğe sahip olmalı & 5 & 18 \\
\hline & Kriz yönetimi iyi olmalı & 4 & 14 \\
\hline & Farklı görüşlere saygı duymalı & 3 & 11 \\
\hline & Uyumlu olmalı & 2 & 7 \\
\hline & Özverili olmalı & 1 & 4 \\
\hline & İnisiyatif alabilmeli & 1 & 4 \\
\hline & Kapsamlı düşünebilmeli & 1 & 4 \\
\hline & Duygu kontrolünü sağlayabilmeli & 1 & 4 \\
\hline & Farkındalık seviyesi yüksek olmalı & 1 & 4 \\
\hline \multirow{14}{*}{$\begin{array}{l}\text { Mesleki } \\
\text { Nitelikler }\end{array}$} & Yol gösterici olmalı & 4 & 14 \\
\hline & Drama sürecini iyi plânlamalı & 4 & 14 \\
\hline & Yorum yapabilmeli & 3 & 11 \\
\hline & Öğrencilerin ilgi ve isteklerine dikkat etmeli & 3 & 11 \\
\hline & Zamanında dönüt vermeli & 3 & 11 \\
\hline & Grubun gelişim özelliklerini iyi bilmeli & 3 & 11 \\
\hline & Tekrardan kaçınmalı & 2 & 7 \\
\hline & Motive edici olmalı & 2 & 7 \\
\hline & Evrensel konulara da yer vermeli & 1 & 4 \\
\hline & Soru sorma yeteneği olmalı & 1 & 4 \\
\hline & Analiz becerisi yüksek olmalı & 1 & 4 \\
\hline & Günceli takip etmeli & 1 & 4 \\
\hline & Dramayı sevdirebilmeli & 1 & 4 \\
\hline & Yönergeleri açık olmalı & 1 & 4 \\
\hline
\end{tabular}

Tablo 1 incelendiğinde, Batman Üniversitesi’nde öğrenim gören öğrenciler öğretim elemanlarının niteliklerini; eğlenceli bir kişiliğe sahip ( $f=5)$, kriz yönetimi iyi olan $(f=4)$, yol gösterici olan $(\mathrm{f}=4)$, drama sürecini iyi planlayabilen $(\mathrm{f}=4)$, yorum yapabilen $(\mathrm{f}=3)$, farklı görüşlere sayg1 duyabilen ( $\mathrm{f}=3$ ), öğrencilerin ilgi ve isteklerine dikkat eden ( $\mathrm{f}=3)$, zamanında dönüt veren $(\mathrm{f}=3)$, grubun gelişim özelliklerini iyi bilen $(\mathrm{f}=3$ ) olarak belirtmişlerdir. Bunun yanı sıra öğrencilerin daha az vurguladıkları nitelikler ise günceli takip eden ( $\mathrm{f}=1)$, dramayı sevdirebilen ( $\mathrm{f}=1)$, farkındalık 
seviyesi yüksek olan ( $\mathrm{f}=1)$ ve yönergeleri açık olan $(\mathrm{f}=1)$ gibi niteliklerin ise öğrenciler tarafindan daha az belirtilen nitelikler olduğu görülmüştür. Öğrencilerin söz konusu nitelikler arasında tema olarak daha çok mesleki nitelikleri vurguladıkları görülmüştür. Aşağıda temalara ilişkin araştırma sürecinde elde edilen görüşmelerden bazı alıntılara yer verilmiştir.

Ö̆̆r. 14: "Bana göre drama dersini verecek olan birinin eğlenceli bir kişiliğe sahip olmast gerekir yoksa ders işlenmez."

Öğr. 7: "Ders sırasında rol gereği bazı sorunları çözüme kavuşturmak gerekir bunun için daima sorun çözebilme yeteneği olmall."

Öğr. 13: "Her ders gibi bunda da hocanın planlı olması lazım."

Öğr. 1: "Bir konu ile ilgili herkes konuşabilmeli, fikirlerini açıkça söyleme cesareti olmalı ama ögrretim elemanının da farklı görüşlere açılk olmalı ki söyleyebilsin."

Araştırma kapsamında, Mardin Artuklu Üniversitesi Çocuk Gelişimi Programında öğrenim gören öğrencilerin çocuk ve drama dersini veren öğretim elemanlarının niteliklerine ilişkin görüşleri Tablo 2'de verilmiştir.

Tablo 2. Mardin Artuklu Üniversitesi’nde Öğrenim Gören Öğrencilerin Öğretim Elemanlarının Niteliklerine İlişkin Görüşleri

\begin{tabular}{|c|c|c|c|}
\hline Temalar & Alt Temalar & f & $\%$ \\
\hline \multirow{10}{*}{ Kişisel Nitelikler } & Yeniliğe açık olmalı & 5 & 38 \\
\hline & Farklı görüşlere saygı duymalı & 5 & 38 \\
\hline & Sevecen olmalı & 3 & 23 \\
\hline & Mesleğini seven & 3 & 23 \\
\hline & Empati kurabilmeli & 2 & 15 \\
\hline & Rol model olmalı & 2 & 15 \\
\hline & Eleştiriye açık olmalı & 2 & 15 \\
\hline & Farklı düşünmeye sevk etmeli & 2 & 15 \\
\hline & Güvenilir olmalı & 1 & 8 \\
\hline & Mizah yeteneği iyi olmalı & 1 & 8 \\
\hline \multirow{9}{*}{$\begin{array}{l}\text { Mesleki } \\
\text { Nitelikler }\end{array}$} & Yol gösterici olmalı & 3 & 23 \\
\hline & Araştırma/Sorgulama yeteneği olmalı & 3 & 23 \\
\hline & Materyal ve kostüm bilgisine sahip olan & 3 & 23 \\
\hline & Öğrencileri aktif kılabilmeli & 2 & 15 \\
\hline & Yetenekleri keşfedebilmeli & 2 & 15 \\
\hline & Uygulama bilgisi olmalı & 1 & 8 \\
\hline & Zamanında dönüt vermeli & 1 & 8 \\
\hline & Özel eğitim bilgisine sahip olmalı & 1 & 8 \\
\hline & Günceli takip etmeli & 1 & 8 \\
\hline
\end{tabular}

Tablo 2 incelendiğinde, Mardin Artuklu Üniversitesi’nde öğrenim gören öğrenciler öğretim elemanlarının niteliklerini; yeniliğe açık olan ( $f=5)$, farklı görüşlere saygı duyan ( $f=5)$, sevecen $(f=3)$, yol gösteren $(f=3)$, araştırma/sorgulama yeteneği olan $(f=3)$, mesleğini seven $(f=3)$, materyal ve kostüm bilgisine sahip olan ( $\mathrm{f}=3$ ) olarak belirtmişlerdir. Bunun yanı sıra uygulama bilgisi olan 
$(\mathrm{f}=1)$, güvenilir ( $\mathrm{f}=1$ ), zamanında dönüt veren ( $\mathrm{f}=1$ ), özel eğitim bilgisine sahip ( $\mathrm{f}=1$ ), günceli takip eden $(\mathrm{f}=1)$, mizah yeteneği olan $(\mathrm{f}=1)$ gibi niteliklerin ise öğrenciler tarafından daha az belirtilen nitelikler olduğu görülmüştür. Öğrencilerin söz konusu nitelikler arasında tema olarak daha çok kişisel nitelikleri vurguladıkları görülmüştür. Aşağıda temalara ilişkin araştırma sürecinde elde edilen görüşmelerden bazı alıntılara yer verilmiştir.

Öğr. 10: "Öğretim elemanı yenilikler açık olmalı ve bu yenilikleri paylaşmayı bilmelidir."

Öğr. 8: "Yeni fikirlere, farklı durumlara açık olmalı ve buna karşı saygılı olmalıdır. Yoksa dersi tek başına işlemek durumunda kalabilir."

Ö̆̆r. 5: "Mesleğinde sevecen olmalı ve bu durumu öğrencilerine yansitmalıdır ki derse karşı ilgi artsin."

Öğr. 12: "Araştırarak kendini sürekli geliştirebilme yeteneği iyi olmall aksi takdirde kendini sürekli tekrar eder ve eski bilgilerle ders işler. Bu da derse olan ilgimizi azaltır."

Araştırma kapsamında, Siirt Üniversitesi Çocuk Gelişimi Programında öğrenim gören öğrencilerin çocuk ve drama dersini veren öğretim elemanlarının niteliklerine ilişkin görüşleri Tablo 3'te verilmiştir.

Tablo 3. Siirt Üniversitesi’nde Öğrenim Gören Öğrencilerin Öğretim Elemanlarının Niteliklerine İlişkin Görüşleri

\begin{tabular}{|c|c|c|c|}
\hline Temalar & Alt Temalar & $\mathbf{f}$ & $\%$ \\
\hline \multirow{16}{*}{ Kişisel Nitelikler } & Empati kurabilmeli & 9 & 56 \\
\hline & Gelişmeye açık olmalı & 6 & 38 \\
\hline & Tutarlı olmalı & 4 & 25 \\
\hline & Hoşgörülü olmalı & 4 & 25 \\
\hline & Çocuk ruhlu olmalı & 3 & 19 \\
\hline & Eleştiriye açık olmalı & 3 & 19 \\
\hline & Kriz yönetimi iyi olmalı & 3 & 19 \\
\hline & Eleştirel düşünebilmeli & 2 & 13 \\
\hline & İdealist olmalı & 2 & 13 \\
\hline & Özgün olmalı & 2 & 13 \\
\hline & Mesleğine karşı saygılı olmalı & 2 & 13 \\
\hline & Farklılıkları iyi yönetmeli & 2 & 13 \\
\hline & Duygu ve düşünceleri özgürce paylaşmalı & 2 & 13 \\
\hline & Arkadaşlık ilişkileri gelişmiş olmalı & 1 & 6 \\
\hline & Sosyal ilişkileri gelişmiş olmalı & 1 & 6 \\
\hline & Hizlı karar alabilmeli & 1 & 6 \\
\hline \multirow{8}{*}{ Mesleki Nitelikler } & Drama sürecini iyi planlamalı & 7 & 44 \\
\hline & Yetenekleri keşfedebilmeli & 3 & 19 \\
\hline & Yapıcı eleştirmeli & 2 & 13 \\
\hline & Yönergeleri açık olmalı & 2 & 13 \\
\hline & Zamanı iyi kullanmalı & 2 & 13 \\
\hline & Merak duygusunu uyandırabilmeli & 1 & 6 \\
\hline & Drama ile hayatı bütünleştirmeli & 1 & 6 \\
\hline & Sözcük daracığı geniş olmalı & 1 & 6 \\
\hline
\end{tabular}


Tablo 3 incelendiğinde, Siirt Üniversitesi'nde öğrenim gören öğrenciler öğretim elemanlarının niteliklerini; empati kurabilen $(f=9)$, drama sürecini iyi planlayan $(f=7)$, gelişmeye açık olan ( $\mathrm{f}=6)$, tutarlı olan $(\mathrm{f}=4)$, hoşgörülü $(\mathrm{f}=4)$, yetenekleri keşfedebilen $(\mathrm{f}=3)$, çocuk ruhlu $(\mathrm{f}=3)$, eleştiriye açık olan $(\mathrm{f}=3)$ ve kriz yönetebilen $(\mathrm{f}=3)$ olarak belirtmişlerdir. Bunun yanı sıra merak duygusunu uyandırabilen ( $\mathrm{f}=1$ ), drama ile hayatı bütünleştirebilen ( $\mathrm{f}=1)$, sözcük daracı $\mathrm{g} 1$ geniş (1), arkadaşlık ilişkileri ( $\mathrm{f}=1$ ) ve sosyal ilişkileri gelişmiş $(\mathrm{f}=1)$ ve hızlı karar alabilen $(\mathrm{f}=1)$ gibi niteliklerin ise öğrenciler tarafından daha az belirtilen nitelikler olduğu görülmüştür. Öğrencilerin söz konusu nitelikler arasında tema olarak daha çok kişisel nitelikleri vurguladıkları görülmüştür. Aşağıda temalara ilişkin araştırma sürecinde elde edilen görüşmelerden bazı alıntılara yer verilmiştir.

Öğr. 13: "Bir hoca öğrencileriyle arkadaş gibi olmalı onlarla empati kurabilmelidir."

Öğr. 9: "Önceden drama dersi ile ilgili bir planının olması lazım bence. Planlı olmadiğ zaman bazen ne yapacağını hoca da biz de düşünmek durumunda kalabiliriz."

Öğr. 7: "Ĕ̆itimde çokyeni fikirler ortaya çımaktadır bununla birlikte yeni teknolojik araçlar ve modeller gelişstiriliyor. Bunları öğrenmek için öğretim elemanı gelişmelere açık olmall."

Öğr. 2: "Özellikle drama dersi çok yönlü bir derstir ve kapsamı da bir o kadar geniştir. Bunun için ders işlerken hocanın bir dediği diğerini tutmalı aksi takdirde öğrenci bazı konuları anlamakta zorlanabilir."

Araştırma kapsamında, Şırnak Üniversitesi Çocuk Gelişimi Programında öğrenim gören öğrencilerin çocuk ve drama dersini veren öğretim elemanlarının niteliklerine ilişkin görüşleri Tablo 4'te verilmiştir.

Tablo 4. Şırnak Üniversitesi’nde Öğrenim Gören Öğrencilerin Öğretim Elemanlarının Niteliklerine Illişkin Görüşleri

\begin{tabular}{|c|c|c|c|}
\hline Temalar & Alt Temalar & f & $\%$ \\
\hline \multirow{12}{*}{$\begin{array}{l}\text { Kişisel } \\
\text { Nitelikler }\end{array}$} & Empati kurabilmeli & 7 & 19 \\
\hline & Eleştiriye açık olmalı & 7 & 19 \\
\hline & Eğlenerek ders işlemeli & 5 & 14 \\
\hline & Pratik düşünebilmeli & 3 & 8 \\
\hline & Liderlik özellikleri olmalı & 3 & 8 \\
\hline & Güler yüzlü olmalı & 3 & 8 \\
\hline & Samimi ve içten olmalı & 2 & 5 \\
\hline & Rol model olmalı & 2 & 5 \\
\hline & Meraklı olmalı & 1 & 3 \\
\hline & Çözüm üretebilmeli & 1 & 3 \\
\hline & Yapıcı olmalı & 1 & 3 \\
\hline & Paylaşmayı sevmeli & 1 & 3 \\
\hline
\end{tabular}


Tablo 4. Şırnak Üniversitesi’nde Öğrenim Gören Öğrencilerin Öğretim Elemanlarının Niteliklerine Ilişkin Görüşleri (Devamı)

\begin{tabular}{llcc}
\hline Temalar & Alt Temalar & f & \% \\
\hline & Grubun gelişim özelliklerini iyi bilmeli & 10 & 27 \\
& Öğrencileri aktif kılabilmeli & 9 & 24 \\
& İyi bir dinleyici olmalı & 7 & 19 \\
& Motive edici olmalı & 7 & 19 \\
& Teori ve uygulamayı birlikte işlemeli & 4 & 11 \\
& Genel kültür bilgisi iyi olmalı & 2 & 5 \\
Nitelikler & Drama sürecini iyi planlamalı & 2 & 5 \\
& Uygulama bilgisi olmalı & 1 & 3 \\
& Öğrenciler arasında etkileşimi sağlayabilmeli & 1 & 3 \\
& Deneyimli olmalı & 1 & 3 \\
& Müzik bilgisi olmalı & 1 & 3 \\
& Sinıf yönetimi konusunda yetkin olmalı & 1 & 3 \\
& Öğrenme psikolojisi bilgisine sahip olmalı & 1 & 3 \\
& Kitap okumayı sevmeli & 1 & 3 \\
& Materyal ve kostüm bilgisine sahip olmalı & 1 & 3 \\
& Teknoloji ile ilgili bilgi sahibi olmalı & 1 & 3 \\
& Farkındalık seviyesi yüksek olmalı & 1 & 3 \\
\hline
\end{tabular}

Tablo 4 incelendiğinde, Şırnak Üniversitesi’nde öğrenim gören öğrenciler öğretim elemanlarının niteliklerini; grubun gelişim özelliklerini iyi bilen ( $\mathrm{f}=10)$, öğrencileri aktif kılan ( $\mathrm{f}=9$ ) aynı zamanda iyi bir dinleyici olan ( $\mathrm{f}=7$ ), öğrencilerini motive edebilen ( $\mathrm{f}=7$ ), empati kurabilen $(\mathrm{f}=7)$, eleştiriye açık $(\mathrm{f}=7)$ ve eğlenerek ders işleyen $(\mathrm{f}=5)$ olarak belirtmişlerdir. Bunun yanı sıra kitap okumayı seven ( $\mathrm{f}=1$ ), materyal ve kostüm bilgisine sahip ( $\mathrm{f}=1)$, teknoloji ile ilgili bilgi sahibi olan ( $\mathrm{f}=1)$, yapıcı $(\mathrm{f}=1)$, paylaşmayı seven $(\mathrm{f}=1)$ ve farkındalık seviyesi yüksek $(\mathrm{f}=1)$ gibi niteliklerin ise öğrenciler tarafından daha az belirtilen nitelikler olduğu görülmüştür. Öğrencilerin söz konusu nitelikler arasında tema olarak daha çok mesleki nitelikleri vurguladıkları görülmüştür. Aşağıda temalara ilişkin araştırma sürecinde elde edilen görüşmelerden bazı alıntılara yer verilmiştir.

Öğr. 19: "Bir drama ĕgitmeni ya da öğretmeni ögrencilerin ilgi ve ihtiyaçlarına göre ders işleyebilmelidir. Bunu yapabilmesi için öğrencilerin her yönden gelişim özelliklerini iyi tanımalı ve buna göre ders işlemelidir."

Öğr. 8: "Drama hocası bütün ögrencilerin yapılan etkinliklere katılımını sağlamalıdır. Bu da dersin daha verimli geçmesini să̆lar."

Öğr. 24: "İyi bir dinleyici olmalıdır. Öğrencilerin konu ile alakalı ve alakasız görüşlerini etkin bir şekilde dinlemeli ve es geçmemelidir."

Öğr. 32: "Motivasyon gücü yüksek olmalı ve bunu öğrencilerine yansitabilmelidir."

Araştırma kapsamında, Batman, Mardin Artuklu, Siirt ve Şırnak Üniversitelerinin Çocuk Gelişimi Programında öğrenim gören öğrencilerin çocuk ve drama dersini veren öğretim elemanlarının niteliklerine ilişkin ortak görüşleri Tablo 5 'te verilmiştir. 
Tablo 5. Batman, Mardin Artuklu, Siirt ve Şırnak Üniversitelerinde Öğrenim Gören Ögrrencilerin Öğretim Elemanlarının Niteliklerine Iliş̧kin Ortak Görüşleri

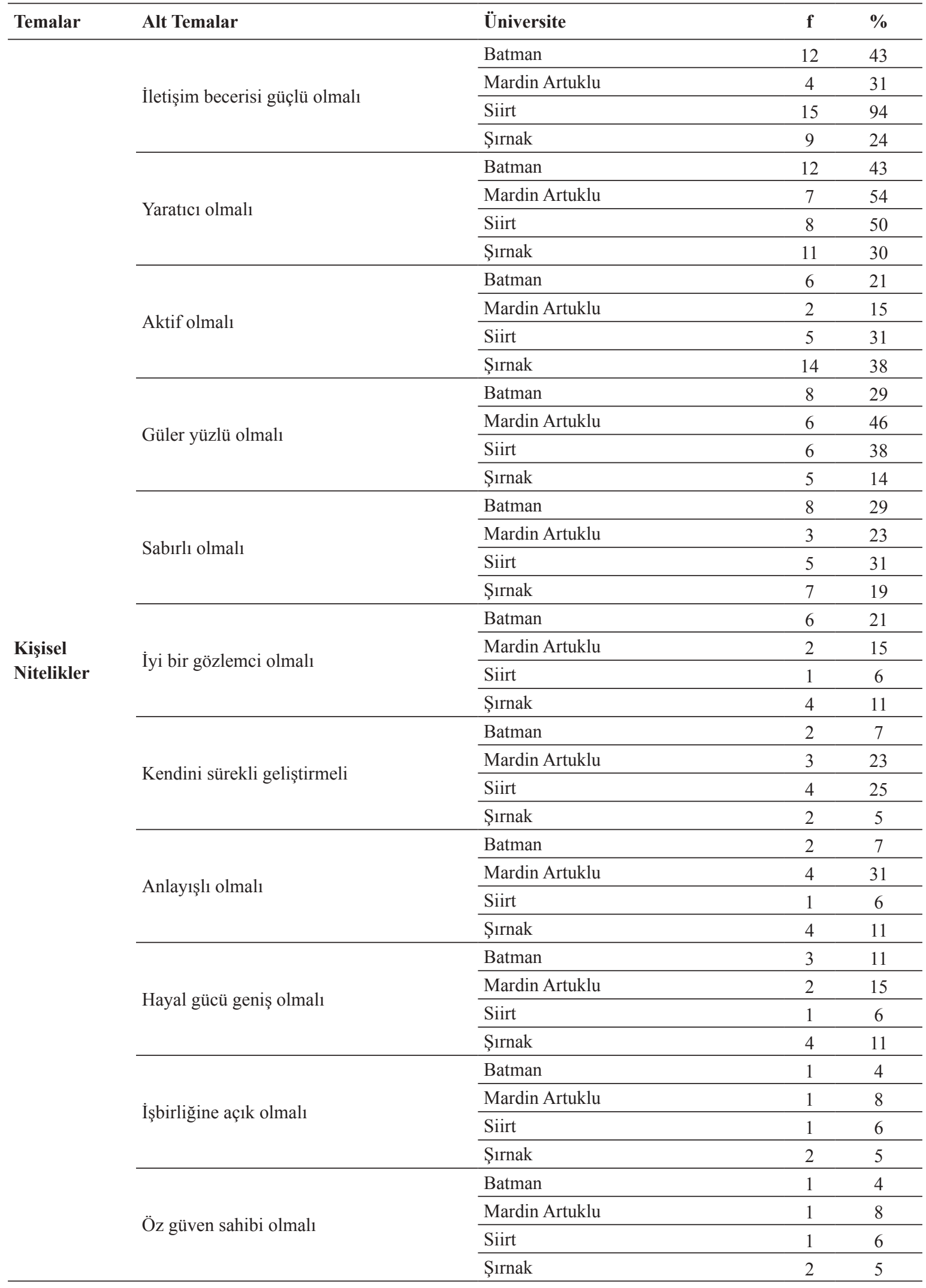


Tablo 5. Batman, Mardin Artuklu, Siirt ve Şırnak Üniversitelerinde Öğrenim Gören Öğrencilerin Öğretim Elemanlarının Niteliklerine İlişkin Ortak Görüşleri (Devamı)

\begin{tabular}{|c|c|c|c|c|}
\hline Temalar & Alt Temalar & Üniversite & f & $\%$ \\
\hline \multirow{20}{*}{$\begin{array}{l}\text { Mesleki } \\
\text { Nitelikler }\end{array}$} & \multirow{4}{*}{ Alan bilgisine sahip olmalı } & Batman & 18 & 64 \\
\hline & & Mardin Artuklu & 4 & 31 \\
\hline & & Siirt & 6 & 38 \\
\hline & & Şırnak & 7 & 19 \\
\hline & \multirow{4}{*}{ Yöntem ve teknik bilgisi iyi olmalı } & Batman & 6 & 21 \\
\hline & & Mardin Artuklu & 9 & 69 \\
\hline & & Siirt & 7 & 44 \\
\hline & & Şırnak & 10 & 27 \\
\hline & \multirow{4}{*}{ Oyun bilgisi olmalı } & Batman & 6 & 21 \\
\hline & & Mardin Artuklu & 1 & 8 \\
\hline & & Siirt & 6 & 38 \\
\hline & & Şırnak & 6 & 16 \\
\hline & \multirow{4}{*}{ Beden dilini iyi kullanabilmeli } & Batman & 1 & 4 \\
\hline & & Mardin Artuklu & 7 & 54 \\
\hline & & Siirt & 7 & 44 \\
\hline & & Şırnak & 1 & 3 \\
\hline & \multirow{4}{*}{ Doğaçlama yeteneğine sahip olmalı } & Batman & 1 & 4 \\
\hline & & Mardin Artuklu & 2 & 15 \\
\hline & & Siirt & 9 & 56 \\
\hline & & Şırnak & 1 & 3 \\
\hline
\end{tabular}

Tablo 5 incelendiğinde, Batman, Mardin Artuklu, Siirt ve Şırnak Üniversitelerinde öğrenim gören öğrenciler öğretim elemanlarının niteliklerini; iletişim becerisi güçlü olan ( $\mathrm{f}=40)$, yaratıcı ( $\mathrm{f}=38$ ), alan bilgisine sahip ( $\mathrm{f}=35$ ), yöntem ve teknik bilgisi iyi olan ( $\mathrm{f}=32$ ), aktif olan (27), güler yüzlü (25), sabırlı ( $f=23$ ), oyun bilgisine sahip ( $f=19)$, beden dilini iyi kullanabilen ( $f=16$ ) ve doğaçlama yeteneğine sahip ( $\mathrm{f}=13$ ) olarak belirtmişlerdir. Bunun yanı sıra işbirliğine açı $(\mathrm{f}=5)$ ve öz güven sahibi ( $\mathrm{f}=5)$ gibi niteliklerin ise öğrenciler tarafindan daha az belirtilen nitelikler olduğu görülmüştür. Dört farkl1 üniversitede öğrenim gören öğrencilerin söz konusu nitelikler arasında ortak tema olarak daha çok kişisel nitelikleri vurguladıkları görülmüştür. Aşağıda araştırma kapsamında yer alan dört farklı üniversitede öğrenim gören öğrencilerin temalara ilişkin araştırma sürecinde elde edilen görüşmelerden bazı alıntılara yer verilmiştir.

Öğr. 2 (Mardin Artuklu Ü.): "Ögrrencilere dersi o kadar güzel ve akıcı anlatmalı ki hem ögrencinin dersi daha kolay anlamasını sağlayabilmeli hem de ögrencinin ilerde iyi bir drama eğitmeni olacağl ihtimalini göz önünde bulundurarak anlatmall."

$\ddot{O} \breve{g r} .11$ (Batman Ü.): "Aslında tüm dersler için geçerli ama drama dersini verecek olan birinin açık ve net konuşmall yani iletişim açısından bir eksiğinin olmaması gerekir."

Öğr. 23 (Şırnak $\ddot{U}$.): “Öncelikle güler yüzlü olmasını isterim ki ders daha eğlenceli ve verimli geçsin."

Öğr. 5 (Siirt Ü.): "Farkl oyunlar bilmeli bence, çünkü derste oyuna çok gerek duyuyoruz." 
Çocuk ve Drama Dersi Veren Öğretim Elemanlarının Niteliklerine İlişkin

Çocuk Gelişimi Programı Öğrencilerinin Görüşleri

\section{Tartışma, Sonuç ve Öneriler}

Araştırma kapsamında üniversitelerin meslek yüksekokulları bünyesinde yer alan Çocuk Gelişimi Programında öğrenim gören öğrencilerin almış oldukları çocuk ve drama dersini veren öğretim elemanlarının niteliklerine ilişkin öğrenci görüşlerini Batman, Mardin Artuklu, Siirt ve Şırnak Üniversiteleri açısından değerlendirilmiştir. Bu amaçla öğrencilerin "Sizce Çocuk ve Drama dersi veren bir öğretim elemanının sahip olması gereken nitelikler nelerdir?” sorusuna ilişkin yanıtları değerlendirilmiştir. Yanıtlar her bir üniversite için ayrı ayrı ele alınmış daha sonra dört üniversitede ögrenim gören öğrencilerin araştırma sorusuna ilişkin ortak görüşlerine yer verilmiştir.

Batman Üniversitesi Çocuk Gelişimi Programında öğrenim gören öğrencilerin çocuk ve drama dersini veren öğretim elemanlarının niteliklerine ilişkin görüşleri incelendiğinde; öğretim elemanının eğlenceli bir kişiliğe sahip olması gerektiği en yüksek frekans değerine sahip nitelik olmuştur. Nitekim Kasapoğlu (2019) tarafindan yapılmış benzer bir çalışmada da yaratıcı drama liderinin kişisel özelliklerine ilişkin katılımcıların en çok vurguladıkları kavram "eğlenceli" kavramı olmuştur. Bu açıdan iki farklı araştırmanın sonuçlarının birbirini destekler nitelikte olduğu söylenebilir. Bunun yanı sıra öğrencilerin en çok vurguladıkları nitelikler; öğretim elemanının kriz yönetimi konusunda iyi olması, yol gösterici başka bir ifadeyle rehber olması ve drama sürecini de iyi planlaması gerektiğidir. Aynı şekilde Millî Eğitim Bakanlığı Öğretmen Yetiştirme ve Eğitimi Genel Müdürlüğü tarafından belirlenen Öğretmenlik Mesleği Genel Yeterlikleri kapsamında belirlenen alt yeterlik alanlarından biri de öğrenciye rehberlik etmektir (MEB, 2006). Bu yönüyle de drama dersini veren bir öğretim elemanının sahip olması gereken nitelikler ile bir öğretmenin sahip olması gereken yeterlikler arasında ortak yeterlik alanlarının olduğu söylenebilir. Bunun yanı sıra aynı üniversitede öğrenim gören öğrencilerin en az vurguladıkları nitelikler arasında ise; dramayı sevdirebilme, farkındalık seviyesi yüksek olma ve yönergeleri açık olma gibi nitelikler yer almıştır. Genel olarak Batman Üniversitesinde öğrenim gören öğrencilerin, öğretim elemanın daha çok mesleki gelişim alanına ilişkin nitelikleri vurguladıkları görülmüştür.

Mardin Artuklu Üniversitesi Çocuk Gelişimi Programında öğrenim gören öğrencilerin çocuk ve drama dersini veren öğretim elemanlarının niteliklerine ilişkin görüşleri incelendiğinde; yeniliğe açık olma, farklı görüşlere saygı duyma, sevecen olma ve yol gösterici olma gibi nitelikleri öğrencilerin daha çok vurguladıkları görülmüştür. Buradan yola çıkarak drama dersini veren bir öğretim elemanının farklı görüşlere saygı duyabilme niteliğine sahip olması önemli bir unsurdur. Ancak bunun tam anlamıyla gerçekleşebilmesi için Keleşoğlu ve Metinnam'ın (2018) belirttiği gibi yaratıcı drama eğitimi alan ve veren kişilerin sosyal adalet tutumlarının yüksek olması beklenir. Yaratıcı drama, sürekli gelişen ve her geçen gün özellikle eğitimdeki önemi ile ön plana çıkan bir alandır. Dolayısıyla bu alanda eğitim verenler hangi eğitim kademesinde olurlarsa olsunlar yenliklere açık olmalıdırlar. Aksi durumda bu alanda ders verenler ya da bir yöntem olarak yaratıcı dramadan yararlanan eğitimciler, kendilerini sürekli tekrar eden kısır döngüsel bir sürecin içinde bulabilirler. Nitekim Okvuran (2003) "Drama Öğretmeninin Yeterlikleri” isimli çalışmasında öğretmenin alanla ilgili yenilikleri izleyebilmeleri gerektiğine vurgu yapmıştır. Bunun yanı sıra aynı üniversitede öğrenim gören öğrencilerin en az belirtikleri nitelikler ise; öğretim elemanının zamanında dönüt vermesi, özel eğitim bilgisine sahip olması, günceli takip etmesi ve mizah yeteneğinin olması gerektiğidir. Bunun da öğrencilerin yaratıcı drama dersini veren öğretim elemanlarından beklentilerinin çok yönlü olduğunu göstermesi açısından önemli bulgular olduğu söylenebilir. Mardin Artuklu Üniversitesi’nde öğrenim 
gören öğrencilerin öğretim elemanının niteliklerine ilişkin genel olarak kişisel nitelikleri sıklıkla belirtikleri görülmüştür.

Siirt Üniversitesi Çocuk Gelişimi Programında öğrenim gören öğrencilerin çocuk ve drama dersini veren öğretim elemanlarının niteliklerine ilişkin görüşleri incelendiğinde; empati kurabilme, drama sürecini iyi planlama, gelişmeye açık olma, tutarlı olma, hoşgörülü olma, çalıştığı grupta var olan yetenekleri keşfedebilme, çocuk ruhlu olma, eleştiriye açık olma ve kriz yönetimi konusunda iyi olma gibi nitelikler daha çok vurgulanmıştır. Vurgulanan temel nitelikler ele alındığında; Siirt Üniversitesi'nde öğrenim gören öğrencilerin bir öğreticiden beklenenlerin yanı sıra duyuşsal alanda bazı niteliklere de değindikleri görülmüştür. Öğrenciler bu durumu, mekanik bir öğretici yerine öğrencisiyle arasında güçlü bir bağ olması gereken, hoşgörülü, empati kurabilen ve çocuk ruhlu olan gibi niteliklerle belirtmişlerdir. Ören (2008) yaratıcılığı desteklemek için gerekli öğretmen özelliklerini sıralarken; hoşgörülü olmanın yanı sıra çocuklara karşı sıcak ve ilgili olma, çocukları sevme ve çocuklara değer verdiğini hissettirme gibi özellikleri belirtmiştir. Bu yönüyle çalışma sonucunda elde edilen nitelikler ile öğretmenlerin sahip olması gereken özelliklerin duyuşsal alan açısından benzerlik gösterdiği söylenebilir. Genel olarak bakıldığında; Siirt Üniversitesi'nde öğrenim gören öğrencilerin öğretim elemanının niteliklerine ilişkin olarak kişisel nitelikleri daha çok vurguladıkları görülmüştür.

Şırnak Üniversitesi Çocuk Gelişimi Programında öğrenim gören öğrencilerin çocuk ve drama dersini veren öğretim elemanlarının niteliklerine ilişkin görüşleri incelendiğinde; grubun gelişim özelliklerini bilme, öğrencileri aktif kılabilme, iyi bir dinleyici olma, motive edici olma, empati kurabilme, eleştiriye açık olma, eğlenerek ders işleme, teori ve uygulamayı birlikte işleme gibi niteliklerin ön plana çıktığı görülmüştür. Öğrenciler tarafından sıklıkla belirtilen niteliklerden özellikle grubun gelişim özelliklerini bilme, öğrenme öğretme sürecinde öğretmenlerin göz önünde bulundurmaları gerekentemel konulardan biridir. Öğretmenin bu durumu gözardı ettiği varsayıldığında ders sürecinin tamamının ve özellikle süreçte uygulanan etkinliklerin amacına ulaşmasında önemli sorunlar ortaya çıabilir. Bu nedenle eğitimin hangi kademesinde olursa olsun öğrencilerin gelişim özelliklerinin bilinmesi öğretmenlerden beklenen bir niteliktir. Bir diğer vurgulanan önemli nitelik ise öğrencilerin aktif kılınmasıdır. Eğitimde çağdaş yönelimler doğrultusunda ortaya çıkan yaklaşımlar, modeller, yöntem ya da teknikler çoğunlukla öğrenciyi süreçte merkeze alan, başka bir deyişle öğrenme öğretme sürecinde bilginin yapılandırılması konusunda öğrenciyi sürecin öznesi yapan yaklaşımlardır. $\mathrm{Bu}$ açıdan değerlendirildiğinde eğitimde ortaya çıkan yeni yönelimlerin temel varsayımı ile çalışmadan elde edilen bazı sonuçların örtüştüğü söylenebilir. Ayrıca Başbuğ ve Adıgüzel (2019) tarafından yapılan bir çalışmada yaratıcı dramanın içinde barındırdığı teknikler aracılığıyla; öğrenmeyi keyifli hale getirdiği, empati becerisini geliştirdiği, etik ve estetik değerlerin gelişmesinde önemli katkılar sağladığı vurgulanmıştır. Bu yönüyle Şırnak Üniversitesi öğrencilerinin öğretim elemanlarına ilişkin belirttikleri niteliklerin bazılarının bu çalışma ile benzerlik gösterdiği söylenebilir. Genel olarak değerlendirildiğinde; Şırnak Üniversitesi’nde öğrenim gören öğrencilerin öğretim elemanının niteliklerine ilişkin olarak sıklıkla mesleki nitelikleri vurguladıkları görülmüştür.

Araştırmada dört farklı üniversitenin birbirinden farklılaşan öğrenci görüşleri ayrı ayrı verilirken, dört üniversitede öğrenim gören öğrencilerin öğretim elemanlarının sahip olması gereken nitelikler konusunda ortak görüş bildirdikleri nitelikler ayrıca belirtilmiştir. 
Buna göre Batman, Mardin Artuklu, Siirt ve Şırnak Üniversitelerinin Çocuk Gelişimi Programında öğrenim gören öğrencilerin çocuk ve drama dersini veren öğretim elemanlarının niteliklerine ilişkin ortak görüşleri incelendiğinde; iletişim becerilerinin güçlü, yaratıcı, alan bilgisine sahip, yöntem ve teknik bilgisi iyi düzeyde, aktif olma, güler yüzlü, sabırl1, oyun bilgisine sahip, beden dilini iyi kullanabilenin yanı sıra doğaçlama yeteneğine sahip gibi nitelikler vurgulanmıştır. Dört üniversitede öğrenim gören öğrencilerin en çok vurguladıkları niteliklerin başında; iletişim becerisi gelmektedir. Bu açıdan değerlendirildiğinde iletişim becerisinin hemen hemen her meslekte olması gereken temel bir nitelik olduğu, ancak yaratıcı drama açısından söz konusu niteliğin öneminin daha çok ön plana çıktığı söylenebilir. Adıgüzel (2018) yaratıcı dramanın genel amaçlarını açıklarken söz konusu amaçlarından birini katılımıının çeşitli iletişim becerilerini geliştirmek olarak belirtmiştir. Dolayısıyla bu sürecin verimli ve etkili bir şekilde geçebilmesi için süreci yöneten, rehberlik eden ya da koordine eden öğretim elemanının da bu beceri konusunda yetkinlik kazanmış olması beklenir.

Öğrenciler tarafından belirtilen bir diğer nitelik ise yaratıcı olmaktır. Bir yaratıcı drama eğitmeninin temel amaçlarından biri de bireyin yaratıcı olmasını sağlamaktır (Adıgüzel, 2018). Bu açıdan ele alındığında bir bireyin yaratıcı yönünün geliştirilebilmesi için eğitmenin ya da öğretim elemanının bu özelliğe sahip olması önemlidir. Dolayısıyla öğrencilerin önemli bir niteliğe dikkat çektikleri söylenebilir. Ayrıca öğrencilerin bir öğretim elemanında olması gereken niteliklerle ilgili olarak alan bilgisine sahip olma ve bu alanla ilgili yöntem ve teknik bilgisine sahip olma gibi iki önemli niteliği vurguladıkları görülmüştür.

Dört farklı üniversitede öğrenim gören öğrencilerin elemanlarının sahip olması gereken nitelikler konusunda ortaklaştıkları tema ve buna bağlı alt temalar incelendiğinde; öğrencilerin sıklıkla kişisel nitelikleri vurguladıkları görülmüştür. Ayrıca araştırma kapsamında öğrencilerin belirttikleri öğretim elemanlarının nitelikleri ile Milli Eğitim Bakanlığı Öğretmen Yetiştirme ve Eğitimi Genel Müdürlüğü tarafından belirlenen Öğretmenlik Mesleği Genel Yeterlikleri kapsamında ele alınan öğretmen yeterliklerinin birçok açıdan örtüştüğü söylenebilir.

Sonuç olarak; bir öğretim elemanın niteliğini ya da mesleki alandaki yeterliliğini en iyi gözlemleyen kişilerin öğrenciler olduğu açıktır. Bu nedenle öğrenci görüşleri açısından öğretim elemanın niteliklerini belirlemek, güvenilir sonuçlar elde edilmesi açısından önemlidir. Ayrıca bir dersin genel amaçları ile öğretim elemanın niteliği arasında bir doğrusallığın olmadığı durumlarda, ders açısından istenilen amaçlara ulaşmanın güçleşeceği savunulabilir. Bu nedenle her bir disiplinin sahip olduğu genel çerçeve ve söz konusu disiplin açısından, ulaşılmak istenen genel amaçlara yol gösteren öğretim elemanının söz konusu amaçlar doğrultusunda bir takım niteliklere sahip olmaları gerekir. Özetle, eğitimin hangi kademesinde olursa olsun dersi vermekle sorumlu olan öğretici konumundaki bireylerin birtakım yeterliklere ya da niteliklere sahip olmaları gerekir. Bu araştırmadan da anlaşılacağı üzere öğrencilerin belirledikleri nitelikleri taşıyan öğretim elemanlarının mesleki yeterlikler açısından da beklentileri büyük ölçüde taşıdıkları söylenebilir. Çalışma sonucunda alan uzmanlarına ve alanda çalışma yapacak olan araştırmacılara şu önerilerde bulunulabilir:

- Üniversitelerde çocuk ve drama dersi veren öğretim elemanlarına yaratıcı drama ile ilgili eğitimler verilebilir.

- Çocuk Gelişimi programlarında yaratıcı drama alanında eğitim almış öğretim elemanlarına görev verilebilir. 
- Bir yaratıcı drama eğitmeninin yeterlikleri ile öğretmen yeterlikleri karşılaştırmalı bir şekilde araştırılabilir.

- Farklı öğretim kademelerinde öğrenim gören öğrencilerin drama eğitmeninin niteliklerine ilişkin görüşleri her öğretim kademesi için ayrı ayrı araştırılabilir.

- Drama eğitmeninin öz yeterlik algıları ile öğrenci görüşleri arasındaki ilişkiyi ele alan araştırmalar yapılabilir.

- Araştırma kapsamında yer alan üniversitelerde öğrenim gören öğrencilerin belirtikleri niteliklerin derslerine giren öğretim elemanları tarafından karşılayıp karşılamadıklarına ilişkin olarak araştırma farklı açıdan ele alınabilir.

- Öğrenciler açısından ders dönemi sonunda öğrenme çıktıları ile öğretim elemanlarının nitelikleri arasındaki ilişki araştırılabilir.

\section{Kaynakça}

Adıgüzel, Ö. (2018). Eğitimde yaratıcı drama. (1. Baskı) İstanbul: Yapı Kredi Yayınları

Başbuğ, S. ve Adıgüzel, Ö. (2019). Müzede yaratıcı drama etkinliklerinin öğrencilerin sosyal bilgiler dersindeki başarılarına etkisi. Yaratıcı Drama Dergisi, 14(1), 1-32

Büyüköztürk, Ş., Kılıç Çakmak E., Akgün, Ö. E., Karadeniz, Ş. ve Demirel, F. (2009). Bilimsel araştırma yöntemleri. (3. baskı). Ankara: Pegem A Yayıncılık.

Çetingöz, D. (2012). Okul öncesi eğitimi öğretmen adaylarının yaratıcı drama yöntemi kullanmaya yönelik özyeterlilkleri. Hacettepe Üniversitesi Eğitim Fakültesi Dergisi, 42(2012), 131-142.

Kara, Ö.T. (2014). Drama lideri olarak Türkçe öğretmeni. Kastamonu Eğitim Dergisi, 22(1), 339-360.

Karasar, N. (2015). Bilimsel araştırma yöntemi. (28. Baskı). Ankara: Nobel Akademik Yayıncılık Eğitim Danışmanlık Tic. Ltd. Şti.

Kasapoğlu, H. (2019). Etkili bir yaratıcı drama liderinin sahip olması gereken özellikler: Katılımcı görüşlerinin nitel analizi. Hacettepe Üniversitesi Ĕgitim Fakültesi Dergisi, 34(1), 106-122. doi:10.16986/ HUJE.2018040671

Keleşoğlu, S. ve Metinnam, İ. (2018). Yaratıcı drama eğitmenlerinin sosyal adalet tutumlarının incelenmesi. Yaratıcı Drama Dergisi, 13(2), 189-198

McCaslin, N. (2016). Yaratıcı drama: sınıf içinde ve dışında. (Çev. Ed. Pınar Özdemir Şimşek), Ankara: Nobel Akademik Yayıncılık. (Eserin orjinali 2006'da yayımlandı).

MEB (2006). Temel eğitime destek projesi “öğretmen eğitimi bileşeni”. Öğretmenlik mesleği genel yeterlikleri. Millı Ĕgitim Bakanlı̆̆ı Tebliğler Dergisi, 69(2590), 1491-1540.

Miles, M. B. and Huberman, A. M. (1994). Qualitative data analysis: An expanded source book. Thousand Oaks: Sage Publications.

Okvuran, A. (2003). Drama öğretmeninin yeterlikleri. Ankara Üniversitesi Eğitim Bilimleri Fakültesi Dergisi, $36(1-2), 81-87$

Ören, M. (2008). Okul öncesinde yaratıcllık ve drama eğitimi, A. Öztürk (Ed.). Okulöncesinde yaratıcıllı̆ı̆ın geliştirilmesi (s. 39-59). Eskişehir: Anadolu Üniversitesi.

Patton, M. Q. (2014). Nitel araştırma ve değerlendirme yöntemleri (Çev. Ed. M. Bütün ve S.B. Demir). Ankara: Pegem A Yayıncılık. (Eserin orjinali 2002'de yayımlandı).

Tutuman, O. Y. (2011). Türkçe öğretmenlerinin yaratıcı drama uygulama yeterlilikleri. Yayımlanmamış yüksek lisans tezi, Dokuz Eylül Ǘniversitesi Eğitim Bilimleri Enstitüsü, İzmir.

Üstündağ, T. (2009). Dramada program gelişstirme. A. Öztürk (Ed.). İlköğretimde drama (s. 75-97). Eskişehir: Anadolu Üniversitesi.

Yıldırım, A. ve Şimşek H. (2013). Sosyal bilimlerde nitel araştırma yöntemleri. (9. Baskı). Ankara: Seçkin Yayıncilik. 


\begin{tabular}{rr} 
çağdaş & Yaratıcı Drama Dergisi 2019, 14(2), 297-308 \\
drama & www.yader.org \\
\hline
\end{tabular}

\title{
Masal Anlatımının İlkokul 4. Sınıf Öğrencilerinin Konuşma Prozodilerine Etkisi
}

\author{
Fatih Çetin Çetinkaya ${ }^{1}$ \\ Muhammet Sönmez ${ }^{2}$
}

\begin{tabular}{|c|c|}
\hline Makale Bilgisi & $\ddot{O} z$ \\
\hline DOI: $10.21612 /$ yader.2019.017 & \multirow{10}{*}{$\begin{array}{l}\text { Masal anlatımının prozodik konuşma becerisine etkisini inceleyen bu çalışma nicel } \\
\text { araştırma desenlerinden ön-test, son-test kontrol deney gruplu deneysel desen } \\
\text { şeklinde tasarlanmıştır. Çalı̧̧ma grubu amaçlı örnekleme yöntemlerinden kolay } \\
\text { ulaşılabilir durum örneklemiyle belirlenmiştir. Çalışma grubunu Kocaeli ilinde } \\
\text { bir devlet okulunda öğrenim gören } 42 \text { ilkokul öğrencisi oluşturmaktadır. Veriler } \\
\text { öğrencilerin hikâye kartlarından masal oluşturmaları esnasında ses kaydı alınarak } \\
\text { toplanmış, sonrasında Konuşma Prozodisi ölçeğiyle puanlanarak SPSS programında } \\
\text { analiz edilmiştir. Uygulama sürecinde deney grubu katılımcılarına } 3 \text { farklı masal } \\
\text { anlatım tekniği kullanılarak toplam } 23 \text { masal anlatılmıştır. Sonuç olarak deney grubu } \\
\text { öğrencilerinin konuşma becerileri ön-test ve son-testleri arasında yüksek düzeyde } \\
\text { anlamlı farklılaşma yaşandiğı görüllmüştür. }\end{array}$} \\
\hline & \\
\hline Geliş tarihi & \\
\hline 10.07.2019 & \\
\hline Anahtar Sözcükler & \\
\hline Masal anlatımı & \\
\hline İlkokul ögrencileri & \\
\hline Prozodi & \\
\hline \multirow[t]{2}{*}{ Makale Türü } & \\
\hline & \\
\hline \multicolumn{2}{|c|}{$\begin{array}{l}\text { The Effect of Fairy Tales on the Prosody of Primary School } 4 \text { th } \\
\text { Grade Students }\end{array}$} \\
\hline Article Info & Abstract \\
\hline DOI: $10.21612 /$ yader.2019.017 & $\begin{array}{l}\text { This study, which examines the effect of the tales of narrative expression on the } \\
\text { prozodic speaking skills, is designed as an experimental design with pre-test and post- }\end{array}$ \\
\hline Article History & test control experimental group. The sample of the study group was determined by the \\
\hline 07.05 .2019 & sampling method which is easily accessible. The study group consisted of 42 primary \\
\hline Accepted & $\begin{array}{l}\text { school students studying in a public school in Kocaeli. The data were collected by } \\
\text { recording the stories of the students with story cards, and then scoring by the Speech }\end{array}$ \\
\hline Keywords & $\begin{array}{l}\text { Prozodic scale and analyzed in the SPSS program. In the application process, } 23 \\
\text { different fairy tales were used for the experimental group participants. As a result, it }\end{array}$ \\
\hline Storytelling & was seen that there was a high level of significant difference between the pre-test and \\
\hline Prozodi & post-test skills of the experimental group students. \\
\hline \multicolumn{2}{|l|}{ Primary school } \\
\hline \multicolumn{2}{|l|}{ Article Type } \\
\hline Research paper & \\
\hline
\end{tabular}

1 Doç. Dr., Düzce Üniversitesi Eğitim Fakültesi, Temel Eğitim Bölümü Sınıf Eğitimi ABD, Kocaeli, Türkiye. E-posta: fatihcetincetinkaya@gmail.com. Orcid ID: 0000-0002-9843-6747

2 Öğretmen, Hacı Seyit Taşan İlkokulu, Kocaeli İl Milli Eğitim Müdürlüğü, Kocaeli, Türkiye. E-posta: muhammetsnmz41@gmail.com. Orcid ID: 0000-0001-6516-7635 


\section{Giriş}

Bireyler kendilerini ifade edebilmek, duygu ve düşüncelerini aktarabilmek için temel dil becerilerine ihtiyaç duymaktadır. Bu beceriler ise sırasıyla dinleme, konuşma, okuma ve yazma olarak gelişim gösterir. İlkokul öğrencileri, eğitim hayatlarına dinleme ve konuşma becerilerine sahip olarak başlar. $\mathrm{Bu}$ dönemde öğrencilerden dinleme ve konuşma becerilerini zamanla geliştirmeleri beklenirken aynı zamanda okuma ve yazma becerileri de kazandırılmaya çalışılır.

Dinleme becerisinden sonra kazanılan konuşma becerisi, bireylerin içinde bulunduğu ortamda kazandığı ve hayatı boyunca kullandığı en önemli iletişim aracı olarak karşımıza çıkmaktadır (Keskin, Baştuğ, ve Akyol, 2013). Konuşma, bireylerin kendilerini ifade etmeleri bakımından oldukça önemli olmakla birlikte, okuma-yazma faaliyetlerinin de temelini oluşturmaktadır (Temizyürek, 2007). Akıc1 ve etkili konuşma becerisini geliştiren öğrenciler bilgilerini de geliştirmekte, sözlü veya sözel olmayan iletişim durumlarına etkili olarak katılmaları kolaylaşmakta, bu durum sayesinde ise öğrencilerin dil ve zihinsel becerileri gelişim göstermektedir (Güneş, 2014). Öğretim programlarında konuşma becerisine yer verilse de uygulama aşamasında konuşma becerisi ihmal edilmektedir (Doğan, 2009; Keskin, Baştuğ, ve Akyol, 2013). Ancak araştırmalar okullarda çocuklar için konuşma etkinlikleri düzenlemesi gerektiğini söylemektedir (Akyol, 2012). Konuşma, diğer dil becerileriyle beraber düşünüldüğünde etkileşim içerisinde bir ortam oluşmakta, doğru ve etkili konuşabilmek için dinleme ve okuma becerileriyle elde edilen birikimlerin etkili bir şekilde kullanılması gerektiği görülmektedir (Sağlam ve Doğan, 2013). Etkili ve akıcı konuşabilmek için öğrencilere verilecek konuşma eğitimi, belirli kurallara dayandırılmış ve ezbere dayalı bir sistemle gerçekleştirilememektedir (Kurudayığlu, 2003). Öğrencilere verilecek konuşma eğitimi, öğrencilerin, kolay, rahat ve akıcı konuşmalarını sağlayacak niteliğe sahip olmalıdır (Doğan, 2009). Konuşmacı, mesaj1 alıcıya net bir şekilde aktarabilmek için akıcı bir şekilde konuşmalı, konuşmadaki vurgu, tonlama ve anlam ünitelerine dikkat etmelidir (Keskin, Baştuğ, ve Akyol, 2013). Bu da prozodik konuşma ile sağlanabilmektedir.

Prozodi; vurgu, tonlama, anlam gruplarına uygun olarak ifade etme olarak açıklanmakta olup, konuşma diline ait bir kavramdır (Breznitz, 2006). Kısacası konuşma dilinin müziği olarak açıklanmaktadır (Allington, 1983; Dowhower, 1991; Kuhn, Schwanenflugel, ve Meisinger, 2010; Schreiber, 1980; Schreiber, 1991). Konuşma prozodisi, konunun yansıtılması ve duygusal boyutların aktarılmasında konuşmacıya yardımcı olurken (Nygaard, Herold, ve Namy, 2009), konuşmayı ilgi çekici hâle getirerek konuşmanın heyecansız ve robotik şekilde sürdürülmesinin önüne geçmektedir (Keskin, Baştuğ, ve Akyol, 2013). Bu durum ise konuşma prozodisinin tonal ve ritmik boyutlarıyla sağlanmaktadır (Çetinkaya, Yıldırım, ve Ateş, 2017).

Prozodik konuşmayı desteklemenin yollarından bir de masallardan yararlanmaktır. Karatay’a (2007) göre masallar, kelime dağarcı̆̆ını zenginleştirerek dil öğretiminin temel becerileri olan anlama ve anlatma becerilerinin kazandırılmasına katkı sağlamaktadır. Masallarda bulunan ritmik unsurlar ve tekerlemeler, anlatım esnasında prozodinin tonal ve ritmik unsurlarını ortaya çıkarmayı kolaylaştırarak, dinleme ve konuşma becerilerini eğlenceli hâle getirmektedir. Bu bağlamda konuşma ve dinlemeyi geliştirmek için masallardan yararlanılmalıdır. Ayrıca masal anlatmak masal okumak değildir, masal anlatıcısı kendi yaşantılarından yararlanarak anlatma eylemini gerçekleştirmektedir (Duran ve Öztürk, 2018). Masal anlatımı esnasında prozodik konuşmaya dikkat edilmesi, canlandırmalardan faydalanılması ve doğru sözcüklerin seçilmesi gerekmektedir (Güleryüz, 2006; Yalçın ve Aytaş, 2003). Çünkü bir masalın dinleyici üzerinde etkili olabilmesi için masal, dinleyiciye 
iyi bir şekilde sunulmalıdır (Duran ve Öztürk, 2018). Masal anlatımında çeşitli yöntemlerden yararlanılabilmektedir. Bu yöntemlere düz anlatım, hikâye veya masal kitabından anlatma, hikâye kartı ile anlatma, pazen tahta ve figürle anlatma, kuklalar ile masal anlatma teknikleri örnek olarak gösterilebilir. (Kirişgil Doğan, 2012).

Alanyazın incelendiğinde konuşma becerisi üzerine yapılan çeşitli çalışmalara rastlanmıştır;

Temizyürek (2007) ilköğretim ikinci kademede konuşma becerilerinin geliştirilmesi adlı çalışmasında, konuşma becerilerinin geliştirilmesi için yapılabilecek çalışmalara yer vermiş ve eğitim kurumlarında konuşma eğitimi için yapılan etkinliklerden söz etmiştir. Sonuç olarak konuşma eğitiminin önemi ilköğretim programında aktarılsa da uygulama esnasında yetersiz kaldığını aktarmıştır. Türkçe eğitiminde kullanılacak olan konuşma eğitiminin öğrencilerin akıc1 ve düzgün konuşmasına katkı sağlayacağını belirtmiştir. Temizkan (2009) öğrencilerin konuşma becerisinde akran değerlendirmenin etkisini araştıran çalışmasında Türkçe öğretmeni adaylarıyla çalışılmış, araştırmanın sonunda akran değerlendirmenin öğrencilerin konuşma becerilerine katk1 sağladığ1 sonucuna ulaşılmıştır. Sağlam ve Doğan (2013) 7. sınıf öğrencilerinin hazırlıksız konuşma becerilerini inceleyen çalışmasında öğrencilerin cümle kurmada sıklıkla hata yaptığı, kelime bulmada zorlandıkları, sık sık kelime ve cümle tekrarlarına düştükleri tespit etmiştir. Çalışmanın sonucunda öğrencilerin hazırlıksız konuşma becerilerinin yetersiz yahut kısmen yeterli olduğu aktarılmıştır. Kuru (2013) akıcı konuşmada sorun yaşan 5. sınıf öğrencileriyle yaptığı çalışmada çeşitli etkinlikler kullanarak akıcı konuşmada problem yaşayan öğrencilerin akıcı konuşmalarını geliştirmeyi amaçlamıştır. Araştırmanın sonucunda karikatür üzerinden konuşma, akıcı konuşma, hazırlıklı konuşma gibi çeşitli etkinliklerin yapılmasının akıcı konuşma problemi yaşayan çocukların konuşmalarına olumlu etki yaptığı belirlenmiştir. Keskin ve diğerleri (2013) ilköğretim 4. sınıf öğrencilerinin sesli okuma ve konuşma prozodileri arasındaki ilişkiyi incelemek adına yaptıkları çalışmada, sesli okuma ve konuşma prozodisi arasında pozitif yönlü bir ilişki tespit etmiş aynı zamanda araştırmaya katılan öğrencilerin \%48'inin konuşma prozodilerinin düşük seviyede olduğu ortaya konulmuştur. Kuru ve Güneş (2017) akıcı konuşma problemi yaşayan 4. sınıf öğrencilerinin akıcı konuşma becerilerini geliştirmeyi amaçlayan çalışmalarında akıcı konuşmayı geliştirme etkinlikleri kullanmışlardır. Sonuç olarak etkinlikler sonrasında öğrencilerin konuşma becerilerinin nicelik ve nitelik olarak geliştiği görülmüştür. Çetinkaya ve diğerleri (2017) ilkokul dördüncü sınıf okuduğunu anlama becerilerine konuşma ve okuma prozodilerinin nasıl etki ettiğini araştırmışlardır. Araştırmanın sonucunda konuşma prozodisinin anlama sürecini kolaylaştırdığ ve okuma sürecinde dikkate alınması gerektiği bilgisine ulaşılmıştır. Deringöl (2018) sınıf öğretmeni adaylarının konuşma kaygılarını incelemiş, tarama modelli ile tasarlanan çalışmanın sonucunda sınıf öğretmeni adaylarının konuşma kaygılarının öğretmenlik yapmalarını engelleyecek seviyede olmadığı, konuşma kaygısının cinsiyet değişkenine göre farklılaşmadığı, sınıf düzeyleri arttıkça konuşma kaygısının azaldığı bilgilerine ulaşmıştır. Özden (2018) Türkçe öğretmeni adaylarının hazırlıklı ve hazırlıksız konuşma hakkında geliştirdikleri metaforları inceledikleri çalışmada, Türkçe öğretmeni adaylarının hazırlıklı konuşma yaparken kendilerini hazırlıksız konuşmaya göre daha yeterli gördükleri sonucuna ulaşılmıştır.

Alanyazında konuşma prozodisi ile masalın birlikte ele alındığı araştırmaya rastlanmamıştır ve bu alanda yapılan benzer araştırmaların az sayıda olduğu görülmüş̧ür. Karatay (2007) dil edinimi ve değer öğretiminde masalın önemi ve işlevini ele almış, Şahin (2011) masalların çocuk 
gelişimine etkilerini öğretmen görüşleriyle incelemiş, Illıcak ve Bal (2019) masal terapinin anaokulu öğrencilerinin sosyal iletişim becerileri üzerindeki etkisini araştırmıştır. Akgün (2017) sıfatların öğretiminde masal/hikâye anlatım yönteminin etkisini belirlemeye çalışmış, Şimşek (2004) ilköğretim tarih dersi konularının öğretiminde hikâye anlatım yönteminin etkililiğini incelemiş, Duran ve Öztürk (2018) etkileşimli masal anlatımının ortaokul 5. sınıf öğrencilerinin dinleme becerileri üzerindeki etkisini araştırmış, Çetinkaya, Topçam ve Sönmez (2019) Drama yönteminin sınıf öğretmeni adaylarının masal yazma becerilerine etkisini değerlendirmiştir.

$\mathrm{Bu}$ araştırmanının problemi ise masal anlatımının konuşma prozodisi üzerinde etkili olup olmadığı şeklinde belirlenmiştir. Bu yüzden masal anlatımının öğrencilerin konuşma prozodilerine etkisini belirlemek amaçlanmıştır. Ana problem doğrultusunda aşağıdaki alt problemlere yanıt bulmak hedeflenmiştir:

1. Masal anlatım tekniği deney grubunda bulunan tüm öğrenciler üzerinde aynı etkiyi sağlar mi?

2. Deney ve kontrol grubunda uygulanan farklı teknikler, bu gruplar arasında bir fark oluşturur mu?

3. Kontrol grubuna uygulanan geleneksel yöntemler katılımcıların prozodik konuşma becerilerini etkiler mi?

\section{Yöntem}

\section{Araştırma Modeli}

Masal anlatımının konuşma prozodisine etkisini incelemeyi amaçlayan bu çalışma, nicel araştırma modellerinden ön-test son-test, kontrol deney gruplu yarı deneysel desen olarak tasarlanmıştır. Deneysel desenlerde amaç yapılan uygulamanın sonuca etkisini belirlemeye çalışmaktır (Creswell, 2014). Yarı deneysel desenlerde gruplar rastgele atanmaktadır (Keppel, 1991).

\section{Çalışma Grubu}

Araştırma Kocaeli ilinde bir devlet okulunda öğrenim gören 42 öğrenciyle beraber yürütülmüştür. Araştırmanın deney grubunu 23 öğrenci oluştururken kontrol grubu 19 öğrenciden oluşmuştur. Araştırmanın çalışma grubu amaçlı örneklem yöntemlerinden kolay ulaşılabilir durum örnekleme yöntemi ile belirlenmiştir. Bu yöntemde araştırmacı ulaşılması ekonomik ve kolay olan duruma yönelir (Glesne, 2015).

\section{Veri Toplama Araçları}

Masal anlatımının konuşma prozodisine etkisini inceleyen bu araştırmanın verileri Samuelsson, Scocco ve Nettelbladt'nn (2003) geliştirdiği “Prozodik Değerlendirme İşlemi”ni temel alarak, Keskin ve diğerleri (2013) tarafından oluşturulan 16 maddelik "Prozodik Konuşma Ölçeği" kullanılarak elde edilmiştir. Ölçeğin güvenirliği için hesaplanan Crombach's Alpha değeri .975 bulunmuştur. Buna ek olarak ölçeğin maddelerinin Konuşma Prozodisini uygunluğu 3 ayrı uzmanın görüşleri neticesinde oluşturulmuştur. Aynı zamanda hikâye kartları, resimli çocuk kitapları ve masal kuklalarından da veri toplama aşamasında yararlanılmıştır. Hikâye kartları toplam 60 adet olmakla beraber her birinin üzerinde farklı bir resim bulunmaktadır. Araştırma sürecinde toplam 
15 adet resimli çocuk kitabı kullanılmış, 3 adet masalın anlatımında kuklalardan yararlanılmıştır. Bunlara ek olarak 5 masal da hikâye kartları ile oluşturulup anlatılmıştır. Masal kahramanlarının betimlenmesi amacıyla kullanılan kuklalar; ördek, kral tacı ve kılıcı, cadısüpürgesi olarak seçilip bu kuklalar aracılığıyla masallar anlatılmıştır.

Tablo 1. Anlatılan resimli çocuk kitapları
1. Hafta
Bay Ka Buk ve Ejder, Balıkçı Osman, Koca Roni
2. Hafta
Kayıktaki Çocuk, Yazı Yazan İnekler, Gezegenimizi Yiyip Bitirdiğimizde,
3. Hafta
Annemin Çantası, Cömert Ağaç, Yolculuk,
4. Hafta
Babam Uyumak Bilmiyor, Pezzettino, Ben Sandalye Değilim
5. Hafta
Bir Fikirle Ne Yaparsın, Bu Kitapta Hiç Resim Yok, Arkadaşım Korku

Tablo 1'de uygulama sürecinde anlatılan kitaplar yer almaktadır.

Uygulama esnasında kullanılan resimli çocuk kitapları uzman görüşleri doğrultusunda prozodi unsurlarını içerme kriteri ile belirlenen 30 kitap arasından yine uzman görüşleri alınarak seçilmiş̧ir. Araştırmanın bu kısmını üç farklı uzmandan yardım alınarak yürütülmüştür.

\section{Verilerin Toplanması}

Masal anlatımının konuşma prozodisine etkisini araştıran bu çalışma ön-test son-test, kontrol deney gruplu yarı deneysel desen olarak tasarlanmıştır. Çalışma grubu amaçlı örnekleme yöntemiyle belirlenerek, Kocaeli ilinde araştırmacının görev yaptığ 1 bir okulda öğrenim gören 42 öğrenci olarak belirlenmiştir. Kontrol deney grubu seçkisiz olarak atanmış, deney grubunu 4-C şubesinde öğrenim gören 23 öğrenci, kontrol grubunu 4-D şubesinde öğrenim gören 19 öğrenci oluşturmuştur. Araştırmanın ön test verilerini elde etmek için her bir katılımcıdan toplam 60 farklı karttan oluşan hikâye kartlarından rastgele 6 tanesini seçmesi ve seçilen kartların üzerinde bulunan görsellerden hareketle katılımcılardan masal oluşturup anlatmaları istenmiştir. Her katılımcı tek tek dinlenmiş ve kartlar karıştırılıp sonraki katılımcı için ortam hazırlanmıştır. Katılımcılar masal anlatırken ses kaydı alınmıştır. Alınan ses kayıtları dinlenerek 16 maddeden oluşan "Konuşma Prozodisi Ölçeğiyle" puanlanmıştır. Puanlama aşamasında 2 araştırmacı da yer almış, araştırma güvenirliği için Miles ve Huberman'ın (1994) önerdiği güvenirlik formülü kullanılmıştır. Puanlama işlemi tamamlandıktan sonrasında Mann Whitney U testi kullanılarak gruplar arasında anlamlı bir fark olmadığ tespit edilmiştir. Bu aşamada yapılan istatistiksel uygulamalar çalışmanın denk gruplar arasında gerçekleştirilmesi için önem arz etmektedir. Grupların denk olduğu sonucuna ulaşıldıktan sonra çalışmaya devam edilmiştir.

Uygulama sürecinde kontrol grubuna herhangi bir işlem uygulanmamış, Türkçe dersi faaliyetleri bakanlık tarafından dağıtılan ders kitaplarında yer alan metinler doğrultusunda yürütülmeye devam edilmiştir. Deney grubunda, uygulama sürecinde önce katılımcılardan bildikleri masalları anlatmaları istenmiş, katılımcıların anlattıkları masallardan yola çıkarak masalın unsurları ve özellikleri aktarılıp oturum sonlandırılmıştır. Masalın unsurları hakkında katılımcıların yeterli bilgiye sahip olmaları sağlandıktan sonra masal anlatma aşamasına geçilmiştir. Masal anlatım tekniklerinden 
kukla ile masal anlatma, hikâye kartları ile masal anlatma ve kitaptan masal anlatma teknikleri ile 5 hafta boyunca toplam 23 masal anlatılmıştır. Hikâye kitapları ile masal anlatma işleminde masala başlamadan önce sınıf oturma düzeni masal formatına göre değiştirilmiş ve hikâye kitaplarının masal özelliklerini tam anlamıyla yansıtması amacıyla hikâyenin başına ve sonuna bir masal tekerlemesi eklenmiştir. Sonrasında Ateş’in (2013) "Peritextual konuşmayla hikâyeye başlama" aşamaları temel alınarak masal anlatma işlemene geçilmiştir. Peritextual okuma kitapta yer alan peritextual unsurlardan (resimli kitapların kılıfi, ön ve arka kapakları, ön kapaktan sonra ve arka kapaktan önce yer alan sayfalar, iç kapak, başlık bölümü, yayıncı ve ithaf bilgileri gibi) söz edilerek peritextual okuma gerçekleştirilmiştir. Peritextual okumanın ardından kitaplar masallaştırılarak anlatılmış, öğrencilerin masalı sosyal hayatla bağdaştırıp, hazırlıksı konuşma becerilerini geliştirmek için masal içeriği ile ilgili etkinlikler gerçekleştirilmiştir.

Tablo 2. Anlatılan resimli çocuk kitapları ve gerçekleştirilen etkinlikler

\begin{tabular}{|c|c|}
\hline Kitaplar & Konuşmaya yönelik etkinlikler \\
\hline Bay Ka Buk ve Ejder & $\begin{array}{l}\text { Öğrencilerden, kitapta tekrar edilen hayal kavramına vurgu yapılarak } \\
\text { "Arkama yaslandım ve hayal kurdum benim hayalim..." cümlesiyle başlayıp } \\
\text { hayalleri anlatmaları istenmiştir. }\end{array}$ \\
\hline Balıkçı Osman & $\begin{array}{l}\text { Öğrencilerden, Balıkçı Osman’ın topladığı çöpleri nasıl daha etkili } \\
\text { kullanabiliriz sorularına yanıt vermeleri istenmiştir. }\end{array}$ \\
\hline Koca Roni & $\begin{array}{l}\text { Koca Roni kitabında yer alan olaylardan hareketle, normal şartlarda } \\
\text { sığamayacakları kadar küçük bir bölgeye arkadaşlarıyla birlikte sığmaları } \\
\text { beklenmiş, ardından dışarıda kalan öğrencilerden ve arkadaşlarını alana } \\
\text { sığdıramayan öğrencilerden neler hissettiklerini anlatmaları istenmiştir., }\end{array}$ \\
\hline Kayıktaki Çocuk & $\begin{array}{l}\text { "Bir Kayık yolcuğu yapsaydınız Nereye gitmek isterdiniz?” soru sorularak } \\
\text { kitapta tekrar eden cümlelerle birlikte öğrencilerin konuşmaları sağlanmıştır. }\end{array}$ \\
\hline Yazı Yazan İnekler & $\begin{array}{l}\text { Öğrencilerden "Tıkır tıkır mööö" ifadesi ile başlayan ve temel ihtiyaçlarımızı } \\
\text { konu alan konuşma yapmaları istenmiştir. }\end{array}$ \\
\hline $\begin{array}{l}\text { Gezegenimizi Yiyip } \\
\text { Bitirdiğimizde }\end{array}$ & $\begin{array}{l}\text { Öğrencilerden “Gezegenimizi yiyip bitirdiğimizde, mağarada saklanan son } \\
\text { çocuk siz olsaydınız, sorunları çözmek için neler yapardınız?” Sorusuna } \\
\text { cevap vermeleri beklenmiştir. }\end{array}$ \\
\hline Annemin Çantası & $\begin{array}{l}\text { Çanta mı süper anne mi? Sorusundan yola çıkarak öğrencilerden “Anneniz } \\
\text { çok ünlü bir süper kahraman olsaydı neler hissederdiniz?” sorusuna yanıt } \\
\text { vermeleri istenmiştir. }\end{array}$ \\
\hline Cömert Ağaç & $\begin{array}{l}\text { Doğanın fedakâr tavrına karşı insanların tavırları sebepler-sonuçlar şeklinde } \\
\text { grup tartışmaları yapılarak ortaya konulmaya çalışılmıştır. }\end{array}$ \\
\hline Yolculuk & $\begin{array}{l}\text { Öğrencilerden gruplar halinde zorunlu göç ile ilgili canlandırmalar } \\
\text { yapmaları istenmiş, canlandırma sonrasında diğer öğrenciler akranlarının } \\
\text { canlandırmaları üzerine eleştiriler sunmuştur. }\end{array}$ \\
\hline Babam Uyumak Bilmiyor & $\begin{array}{l}\text { Uyku düzenin ve zinde olmanın önemi hakkında öğrencilerden ikna edici } \\
\text { konuşma yapmaları beklenmiştir. }\end{array}$ \\
\hline Pezzettino & $\begin{array}{l}\text { Ben kimin parçasıyım acaba sorusundan yola çıkarak, sınıf içersinde kitapta } \\
\text { geçen olaylar dramatize edilmiş, insanların kendilerini oldukları gibi neden } \\
\text { kabul etmedikleri sorunsa yanıt aranmıştır. }\end{array}$ \\
\hline
\end{tabular}


Tablo 2. Anlatılan resimli çocuk kitapları ve gerçekleştirilen etkinlikler (Devamı)

\begin{tabular}{|c|c|}
\hline Kitaplar & Konuşmaya yönelik etkinlikler \\
\hline Ben Sandalye Değilim & $\begin{array}{l}\text { Kendini ifade edebilme yeteneğinin önemi hakkında öğrencilerin düşünceleri } \\
\text { alınmıştır. }\end{array}$ \\
\hline Bir Fikirle Ne Yaparsin & $\begin{array}{l}\text { "Bir fikirle dünyayı değiştirebilirsin ifadesiyle ne anlatılmak isteniyor? } \\
\text { Sorusuyla öğrencileri konuşmaya sevk edilmiştir. }\end{array}$ \\
\hline Bu Kitapta Hiç Resim Yok & $\begin{array}{l}\text { Öğrencilerden hangi tür kitapları okumayı tercih ettikleri ve kitap seçerken } \\
\text { nelere dikkat ettiklerini açıklamalar istenmiştir. }\end{array}$ \\
\hline Arkadaşım Korku & $\begin{array}{l}\text { Öğrencilerden korkularını açıklamaları istenmiş ve akranları ile birlikte bu } \\
\text { korkularla nasıl mücadele edebileceği üzerine konuşmaları sağlanmıştır. }\end{array}$ \\
\hline
\end{tabular}

Kuklalar ve hikâye kartları ile anlatılan masallar doğaçlama olarak anlatım esnasında tasarlanmış, 5 hafta boyunca haftada bir masal 60 tane hikâye kartının arasından rastgele seçilen 5 kartın üzerindeki görsellerden yararlanılarak kurgulanmıştır. Kuklalardan anlatılan masallarda da aynı yöntem izlenmiş, anlatım esnasında oluşturulan 3 masalın anlatımı kuklalar yardımıyla gerçekleştirilmiştir. Uygulama aşamasında kullanılan masallar da prozodik ögelerin varlığı bu çalışmada kullanılmalarında kriter olarak ele alınmıştır. Bu sayede konuşma prozodisi anlatım esnasında öğrencilere daha kolay hissettirileceği düşünülmüştür. Ayrıca kitapların belirlenme sürecinde 3 farklı uzmandan yardım alınmıştır.

5 hafta süren uygulama aşaması sonrasında katılımcılara ön testte yapılan işlem tekrarlanılmış, her katılımcının tek tek masalını anlatması için ortam hazırlanmış ve hikâye kartları arasından seçilen 6 karttan masal kurgulayıp anlatmaları istenmiştir. Masal anlatımı esnasında ses kaydı alınarak katılımcıların konuşma prozodileri sonrasında Konuşma Prozodisi Ölçeği aracılığıyla puanlanmıştır. Puanlama 2 araştırmacı tarafından gerçekleştirilmiş ve Miles ve Huberman'ın (1994) önerdiği güvenirlik formülü kullanılmıştır. Deney ve kontrol grubu verileri üzerinden gerekli analizler yapılarak araştırma sonlandırılmıştır.

\section{Verilerin Analizi}

Konuşma Prozodisi Ölçeğiyle elde edilen veriler 2 araştırmacı tarafindan dinlenerek puanlandıktan sonra nicel veriler hâline getirilmiştir. Araştırmacılar arasındaki görüş birliği belirlemek için Miles ve Huberman'ın (1994) önerdiği güvenirlik formülü kullanılmıştır. Hesaplama sonucunda araştırmanın güvenirlik değeri \%85 olarak tespit edilmiştir. Bu formüle göre kodlayıcılar aras1 görüş birliği en az \%80 olmalıdır (Miles ve Huberman, 1994;Patton, 2002).

Güvenirlik = Görüş Birliği / (Görüş Birliği + Görüş Ayrılığı)

Analiz aşamasında SPSS programından yardım alınmıştır. Araştırma esnasında anlamlılık değeri 0.05 kabul edilerek verilerin normallik durumlarına göre yapılacak teste karar verilmiştir. Normal dağılım gösteren tekrarlı ölçümlerde Paried Sample T Testi, Normal dağılım göstermeyen tekrarlı ölçümlerde Wilcoxon işaretli sıralar testi kullanılmış, normal dağılmayan bağımsız iki grubun verilerinde ise Mann-Whitney $U$ testi ile analizler gerçekleştirilmiştir. 


\section{Bulgular}

Verilerin bulgular hâline getirilmesinde öncelikle verilerin normallik durumları SPSS programı kullanılarak incelenmiştir. Kontrol grubunun ön-test puanlarının normallik dağılımı 0.404, son test puanlarının normallik dağılımı 0.197 olarak tespit edilmiştir. Kontrol grubunun ön test ve son test puanları $\mathrm{P}>0.05$ olduğu için normal dağıldığı sonucuna ulaşılmıştır. Deney grubu ön test verileri analizler sonucunda 0.024 olarak tespit edilmiş, $\mathrm{P}<0.05$ olması sebebiyle ön test verilerinin normal dağılmadığ 1 , son test verilerinin ise 0.090 olarak $\mathrm{P}>0.05$ normal dağ 1 ldı $\breve{g}_{1}$ sonucuna ulaş1lmıştır.

Tablo 3. Deney ve Kontrol Grubundaki Katılımclları Ön-Test Puanlarına Ait Mann Whitney U Testi Sonuçları

\begin{tabular}{llccccc}
\hline Ön-Test & & $\mathbf{n}$ & $\overline{\mathbf{x}}$ & $\boldsymbol{U}$ & $\boldsymbol{Z}$ & $\mathbf{p}$ \\
\hline Konuşma & Deney & 23 & 15.96 & 208.00 & -.226 & .790 \\
Prozodisi & Kontrol & 19 & 14.32 & & & \\
& Toplam & 42 & 15.21 & & & \\
& & & & & & \\
\hline
\end{tabular}

Tablo 3' de deney ve kontrol grubunun ön test puanlarına ait Mann Whitney U testi sonuçlarına yer verilmiştir. Tablo incelendiğinde deney grubundaki katılımcıların aldıkları puanların ortalaması 15.96, kontrol grubundaki katılımcıların aldıkları puanların ortalaması 14.32 olduğu görülmektedir. Bunlara ek olarak araştırmaya katılan tüm katılımcıların ortalaması ise 15.21 olarak tespit edilmiştir. Ayrıca Mann Witney U Testi sonuçlarına göre deney ve kontrol gruplarının konuşma prozodileri arasında anlamlı bir fark olmadığı görülmektedir $(Z=-226, p>.05)$.

Tablo 4. Kontrol Grubundaki Katılımcıların Ön-Test ve Son Test Puanlarının Paried Sample T testi ile Karşılaştırılması

\begin{tabular}{llcccc}
\hline Kontrol Grubu & & $\mathbf{n}$ & $\overline{\mathbf{x}}$ & $\boldsymbol{s s}$ & $\mathbf{p}$ \\
\hline Konuşma Prozodisi & Ön-Test & 19 & 14.32 & 2.59 & .023 \\
& Son-Test & 19 & 15.79 & & \\
\hline
\end{tabular}

${ }^{*} \mathrm{p}<.05$

Tablo 4'de kontrol grubunun ön-test ve son-test puanlarının bağımlı T Testi ile karşılaştırılması sonucu elde edilen bulgular görülmektedir. Tablo incelendiğinde kontrol grubunun ön-test, son- test verilerinin anlamlı şekilde farklılaştığ görülmektedir $(.023, \mathrm{p}<.05)$.

Tablo 5. Deney Grubundaki Katılımcıların Ön-Test ve Son Test Puanlarının Wilcoxon İşaretli Stralar Testi ile Karşılaştırılması

\begin{tabular}{llccccc}
\hline Son-Test / Ön-Test & & n & Sıra Ort. & Sıra Top. & z & p \\
\hline Konuşma Prozodisi & Negatif Sıra & 2 & 10.00 & 20.00 & $-3,593$ & .000 \\
& Pozitif Sıra & 21 & 12.19 & 256.00 & & \\
& Eşit & - & - & - & & \\
\hline
\end{tabular}

${ }^{*} \mathrm{p}<.05$

Tablo 5' de deney grubunun ön-test ve son-test puanlarından aldıkları puanların Wilcoxon işaretli sıralar testi ile karşılaştırma sonucuna yer verilmiştir. Tablo incelendiğinde deney grubunun öntest son-test puanları arasında oldukça yüksek derecede anlamlı bir farklılaşma olduğu görülmektedir $(.00, \mathrm{p}<.05)$. 
Tablo 6. Deney ve Kontrol Grubundaki Katılımcılarn Son-Test Puanlarına Ait Mann Whitney U Testi Sonuçları

\begin{tabular}{llccccc}
\hline Son-Test & & $\mathbf{n}$ & $\overline{\mathbf{x}}$ & $\boldsymbol{U}$ & $\boldsymbol{Z}$ & $\mathbf{p}$ \\
\hline Konuşma & Deney & 23 & 24.61 & 103.00 & -2.925 & .003 \\
Prozodisi & Kontrol & 19 & 15.79 & & & \\
& Toplam & 42 & 20.62 & & & \\
\hline
\end{tabular}

${ }^{*} \mathrm{p}<.05$

Tablo 6' da deney ve kontrol grubuna ait son-test puanlarının Mann Whitney U testi analiz sonuçlarına yer verilmiştir. Tablo incelendiğinde Deney grubunda alınan puanların ortalamasının 24.61, kontrol grubunda alınan puanların ortalamasının 15.79 olduğu görülmektedir. Toplam puanların ortalaması ise 20.62 olduğu sonucuna ulaşılmıştır. Bu duruma göre deney grubunda alınan puanların ortalamasının kontrol grubuna göre yüksek olduğu söylenebilir. Ayrıca iki grubun son test verileri arasında yüksek derecede bir anlamlı fark olduğu görülmektedir ( $Z=-2925, \mathrm{p}<.05)$.

\section{Tartışma, Sonuç ve Öneriler}

Masalların dil edinimi ve değer öğretimi, sosyal iletişim becerileri, çocuk gelişimi gibi çeşitli alanlarda önemli etkileri olduğu birçok araştırma tarafından ortaya konulmuştur (Akgün, 2017; Duran ve Öztürk, 2018; Illıcak ve Bal, 2019; Karatay, 2007; Kirişgil Doğan, 2012; Şahin, 2011; Şimşek, 2004) . Karatay (2007), evrensel değerlerin öğretiminde ve dil becerilerinin gelişiminde masalların önemli yeri olduğunu aktarmaktadır. Bu çalışmada da dil becerilerinden biri olan konuşma becerisinin gelişimi masal anlatımıyla yöntemiyle incelenmiş, araştırma sonucunda Karatay’ın (2007) aktardığı sonuca bezer bir şekilde masal dinleyen çocukların konuşma becerileri önemli ölçüde gelişim gösterdiği görüşmüştür. Masalların hayal gücünü kullanmaya olanak tanıması, iyi kötü kavramlarının bir arada kullanılmasıyla çeşitli zıtlıkları bir araya getirmesi, masal dinleyen öğrencileri farklı yaşantılarla karşı karşıya bırakarak öğrencilerin kelime hazinelerini etkilemektedir. $\mathrm{Bu}$ bağlamda kelime hazinesi gelişen çocukların konuşma becerileri de önemli şekilde ilerleme göstermektedir. Duran ve Öztürk (2018) benzer bir çalışmada etkileşimli masal anlatımının ilkokul öğrencilerinin dinleme becerileri üzerindeki etkisini incelmiş, sonuç olarak etkileşimli masal dinleyen çocukların, geleneksel yöntemle masal dinleyen çocuklara göre dinleme becerilerinin anlamlı şekilde farklılaştı̆̆ını aktarmıştır. Dil becerileri ele alındığında dinleme becerisinin kazanılmasından sonra konuşma becerisi gelişim göstermeye başlamaktadır. Duran ve Öztürk'ün (2018) çalışmasında ulaşılan sonuçlar bu çalışmanın sonuçlarını desteklediği söylenebilir. Dinleme becerisi yüksek olan öğrenciler konuşma becerileri de bundan olumlu bir şekilde etkilenecektir. Masal anlatımı da hem dinlemeyi hem de konuşmayı etkileyen önemli bir yöntemdir. Keskin ve diğerleri (2013) sesli okuma ve konuşma prozodisi arasındaki ilişkiyi inceleyen çalışmaları sonucunda, sesli okuma ve konuşma prozodisi arasında orta düzeyde pozitif yönlü bir ilişki tespit etmiştir. Çetinkaya ve diğerleri (2017) ise okuduğunu anlama becerileri üzerinde konuşma prozodisinin de etkili olduğunu belirlemiştir. Bu sonuçlardan yola çıkarak masal anlatımının dinleme ve konuşma becerilerine doğrudan, okuma ve anlama becerilerine ise dolaylı olarak katkı sağladığı söylenebilir.

Illıcak ve Bal (2019) temel konuşma becerilerini temel alarak yaptıkları çalışmada, okul öncesi öğrencilerinin sosyal iletişim becerilerine masal terapinin etkisini incelemiştir. Araştırma 
sonucundan masal terapinin katılımcıların sosyal iletişim becerileri üzerinde önemli ölçüde etkiliği olduğu tespit edilmiştir. Masal dinlemenin prozodik konuşmayı desteklemesi, prozodi içerisinde yer alan anlam üniteleri, vurgu-ses-tonlama unsuru gibi konuşma içerisindeki anlamı aktarmakta önem arz eden araçlar sosyal iletişim açısından oldukça önemlidir. Masal anlatım yöntemiyle öğrencilerin prozdik konuşmaları sağlanabilir bununla birlikte sosyal iletişim becerileri yükseltilebilir.

Masal anlatımının konuşma prozodisinde bu denli etkili olmasının bir sebebi de masal anlatım yönteminin öğrencilerin kelime hazinelerini desteklemesidir. Kelime hazinesi desteklenen öğrenciler bu durumu konuşmalarına yansıtarak prozodik bir şekilde konuşa bilmektedir. Akgün (2017) sıfatların öğretiminde masal anlatım yönteminin etkisini incelemiş, araştırma sonunda masal anlatımının Türkçe derslerinde yalnızca dinleme ve konuşma becerileri üzerinde etkili olmadığı bu becerilerin yanı sıra öğrencilerin sözcük dağarcığı olumlu yönde etkilediğini belirlemiştir.

Sonuç olarak öğrencilerin temel dil becerilerinin birçoğu ve prozodik konuşma becerileri masal anlatım teknikleri kullanılarak geliştirilebilir.

Araştırma sonrasında öğretmenlerin Türkçe dersleri içerisinde öğrencilere masal anlatmaları, eğitim fakülteleri bünyesinde bulunan Çocuk Edebiyatı derslerinde masal anlatım tekniklerinin öğretmen adaylarına etkili bir şekilde aktarılması, sınıf öğretmenlerinin masallar aracılığıyla ders içi etkinlikleri zenginleştirmeleri, öğrencilere masal anlatım teknikleriyle masallar anlattırarak konuşma prozodilerini geliştirecek uygulamalar yapmaları önerilebilir. Aynı zamanda masal anlatım yönteminin öğrencilerin kelime hazinelerine etkisini ölçmeyi hedefleyen araştırmalar da yapılabilir. 


\section{Kaynakça}

Akgün, N. (2017). Sıfatların öğretiminde masal/hikâye anlatım yönteminin etkisi. International Journal of Languages' Education and Teaching, 5(3), 662-671.

Akyol, H. (2012). Programa uygun Türkçe ögretim yöntemleri. Ankara: Pegem Akademi.

Allington, R. L. (1983). Fluency: The neglected reading goal. The Reading Teacher, (36), 556-561.

Ateş, S. (2013). İlkokulda peritextual okumadan metinler arası okumaya resimli hikâye kitabı okuma süreci. International Journal of Human Sciences, 10(1), 1567-1585.

Breznitz, Z. (2006). Fluency in reading: Synchronization of processes. Mahwah, NJ, US: Lawrence Erlbaum Associates Publishers.

Creswell, J. W. (2014). Araşstırma deseni (4.bs.). Ankara: Eğiten Kitap.

Çetinkaya, F. Ç., Topçam, A. B. ve Sönmez, M. (2019). Drama yönteminin sınıf öğretmeni adaylarının masal yazma becerilerine etkisi. Ana Dili Ë̆itimi Dergisi, 7(2), 337-352.

Çetinkaya, F. Ç., Yıldırım, K. ve Ateş, S. (2017). İlkokul dördüncü sınıf öğrencilerinin okuduğunu anlama becerilerinin üzerinde konuşma ve okuma prozodisinin etkisi. Türkiye Sosyal Araştırmalar Dergisi, 451-464.

Deringöl, Y. (2018). Sınıf öğretmeni adaylarının konuşma kaygıları. MCBÜ Sosyal Bilimler Dergisi, 16(3), 23-35.

Doğan, Y. (2009). Konuşma becerisinin geliştirilmesine yönelik etkinlik örnekleri. Türk Eğitim Bilimleri Dergisi, 7(1), 185-204.

Dowhower, S. L. (1991). Speaking of prosody: Fluency's unattended bedfellow. Theory into Practice, (30), 165-175.

Duran, E. ve Öztürk, E. (2018). Etkileşimli masal anlatım tekniğinin ortaokul 5. sınıf öğrencilerinin dinleme becerilerine etkisi. Avrasya Dil Eğitimi ve Araştırmaları Dergisi, 2(2), 85-103.

Glesne, C. (2015). Becoming qualitative researchers: An introduction (5.bs.). Boston: Pearson Education.

Güleryüz, H. (2006). Yaratıcı çocuk edebiyatı. Ankara: Pegem A Yayıncılık.

Güneş, F. (2014). Konuşma öğretimi yaklaşım ve modelleri. Bartın Üniversitesi Eğitim Fakültesi Dergisi, 3(1), $1-27$.

Illıcak, N. G. ve Bal, F. (2019). Masal terapinin anaokulu öğrencilerinin sosyal iletişim becerileri üzerindeki etkisinin incelenmesi. Avrasya Sosyal ve Ekonomi Araştırmaları Dergisi, 6(3), 517-533.

Karatay, H. (2007). Dil edinimi ve değer öğretimi sürecinde masalın önemi ve işlevi. Türk Egitim Bilimleri Dergisi, 5(3), 463-475.

Keppel, G. (1991). Design and analysis: A researcher's handbook. NJ: Prentice Hall: Englewood Cliffs.

Keskin, H. K., Baştuğ, M. ve Akyol, H. (2013). Sesli okuma ve konuşma prozodisi: İlişkisel bir çalışma. Mersin Üniversitesi Eğitim Fakültesi Dergisi, 9(2), 168-180.

Kirişgil Doğan, F. (2012). Okul öncesi dönemde masal öğretiminde insancıl (hümanist) ve teknolojik (e-kitap) yöntemlerinin karşılaştırılması. (Yayımlanmamış Yüksek Lisans Tezi). Necmettin Erbakan Üniversitesi Eğitim Bilimleri Enstitüsü Konya.

Kuhn, M. R., Schwanenflugel, P. J., ve Meisinger, E. B. (2010). Aligning theory and assessment of reading fluency: Automaticity, prosody, and definitions of fluency. Reading Research Quarterly, 42(2), 230-251.

Kuru, O. (2013). Akıcı konuşma problemi yaşayan ilköğretim 5. sınıf öğrencilerinin konuşma becerisine etkisi. Uluslararası Türk Eğitim Bilimleri Dergisi(1), 88-105.

Kuru, O. ve Güneş, F. (2017). Akıcı konuşma problemi yaşayan ilkokul 4. sınıf öğrencilerinin konuşma becerilerinin geliştirilmesi. Erzincan Üniversitesi Eğitim Fakültesi Dergisi, 19(1), 33-47.

Kurudayığlu, M. (2003). Konuşma eğitimi ve konuşma becerisini geliştirmeye yönelik etkinlikler. Türk Bilimi Araştırmalarl(13), 287-309. 
Miles, M, B. ve Huberman, A. M. (1994). Qualitative data analysis: An expanded Sourcebook. (2nd ed). Thousand Oaks, CA: Sage.

Nygaard, L. C., Herold, D. S. ve Namy, L. L. (2009). The semantics of prosody: Acoustic and perceptual evidence of prosodic correlates to word meaning. Cognitive Science, 33(1), 127-146.

Özden, M. (2018). Türkçe eğitimi lisans öğrencilerinin hazırlıklı ve hazırlıksız konuşma hakkında geliştirdikleri meteforlar. Ordu Üniversitesi Sosyal Bilimler Araştırmaları Dergisi, 8(2), 347-357.

Patton, M.Q. (2002). Qualitative research and evaluation methods (3rd Ed.). London: Sage Publications, Inc.

Sağlam, Ö. ve Doğan, Y. (2013). 7. sınıf öğrencilerinin hazırlıksız konuşma becerileri. Mustafa Kemal Üniversitesi Sosyal Bilimler Enstitüsü Dergisi, 10(24), 43-56.

Samuelsson, C., Scocco, C. ve Nettelbladt, U. (2003). Towards assessment of prosodic abilities in swedish children with language impairment. Logopedics Phoniatrics Vocology, 28(4), 156-166.

Schreiber, P. A. (1980). On the acquisition of reading fluency. Journal of Reading Behavior, (12), 177-186.

Schreiber, P. A. (1991). Understanding prosody's role in reading acquisition. Theory Into Practice, (30), 158164.

Şahin, M. (2011). Masalların çocuk gelişimine etkilerinin öğretmen görüşleri açısından incelenmesi. Millî Folklor, (89), 208-219.

Şimşek, A. (2004). İlköğretim okulu sosyla bilgiler dersi tarih konularının öğretiminde hikaye anlatım yönteminin etkililiği. Türk Ë̆itim Bilimleri Dergisi, 2(4), 495-509.

Temizkan, M. (2009). Akran değerlendirmenin konuşma becerisinin geliştirmesi üzerindeki etkisi. Mustafa Kemal Üniversitesi Sosyal Bilimler Enstitüsü Dergisi, 6(12), 90-112.

Temizyürek, F. (2007). İlköğretim ikinci kademede konuşma becerisinin geliştirilmesi. Ankara Üniversitesi Ĕgitim Bilimleri Fakültesi Dergisi, 40(2), 113-131.

Yalçın, A. ve Aytaş, G. (2003). Çocuk edebiyatı. Ankara: Akçă̆ Yayınları.

\section{Ekler}

Ek 1. Bay Ka Buk ve Ejder kitabı örnek etkinlik planı

Hazırlık Çalışmaları

Masal anlatımına geçiş aşaması

\section{Masal anlatımı sonrası konuşmaya yönelik çalışmalar}

Bu aşamada sınıf fiziksel ortamı masal anlatımına uygun hale getirilmek için düzenlenmiştir. İlk olarak oturma düzeni değiştirilerek hilal oturma düzenine geçilmiştir. Ardında bu hilalin içersine öğrenciler toplanarak ısınma çalışması gerçekleştirilmiştir.

Peritextual okumaya başlayarak kitap tanıtılmış, kitabın kapağında bulunan resimler, ön iç kapak ve arka iç kapakta bulunan peritextual ögeler, kitabın künyesi hakkında konuşmuştur. Öğrencilerin kitabın içeriği hakkında görüşleri alındıktan sonra kitap masallaştırılarak anlatılıışır.

Anlatımın ardından kitap içerisinde tekrar eden hayal kavramına vurgu yapılarak öğrencilerden "arkama yaslandım ve hayal kurdum benim hayalim..." cümlesiyle başlayıp hallerini anlatmları istenmiştir. Masal anlatımı ve etkinlikler tamamlandıktan sonra öğrencilerin masal ve etkinlere yönelik eleştirileri dinlenmiştir. 


\begin{tabular}{rr} 
çağdaş & Yaratıcı Drama Dergisi 2019, 14(2), 309-320 \\
drama & www.yader.org \\
\hline
\end{tabular}

\section{"Promoting the Acceptance of the 'other' through Drama in Education"}

Theodora Papaioannou ${ }^{1}$

\begin{tabular}{|c|c|}
\hline \multicolumn{2}{|r|}{ Alkistis Kondoyianni ${ }^{2}$} \\
\hline Article Info & Abstract \\
\hline DOI: 10.21612/yader.2019.018 & $\begin{array}{l}\text { The present study concerns the exploration of the effect of the techniques of drama in } \\
\text { education on the acceptance of the "other". A review of the relevant literature and }\end{array}$ \\
\hline Article History & a comparison of studies on a worldwide level provide the required theoretical and \\
\hline Received & research background for the foundation of the specific educational theatre program \\
\hline 10.07.2019 & $\begin{array}{l}\text { which concerned the use of drama in education techniques in the frame of intercultural } \\
\text { education. Specifically, during the implementation of the educational theatre program, }\end{array}$ \\
\hline Keywords & acceptance and collaboration of students coming from different cultural environments. \\
\hline Drama in education techniques & The results of this study were positive in that the role-playing and teamwork techniques \\
\hline Acceptance of the "other" & of drama in education contributed to the creation of a suitable environment to achieve \\
\hline Primary education & acceptance of the "other" as well as the interaction, communication, collaboration \\
\hline Intercultural education & $\begin{array}{l}\text { and mutual acceptance between the students who participated in the educational } \\
\text { theatre program. }\end{array}$ \\
\hline
\end{tabular}

Article Type

Research paper

Eğitimde Drama ile ‘Ötekinin' Kabulünü Teşvik Etmek

\begin{tabular}{l}
\hline Makale Bilgisi \\
\hline DOI: $10.21612 /$ yader.2019.018
\end{tabular}

\section{Makale Geçmişi}

Geliş tarihi $\quad 25.04 .2019$

Kabul 10.07.2019

Anahtar Sözcükler

Eğitimde drama teknikleri

“öteki” nin kabulü, Illköğretim

Kültürlerarası eğitim

Ĕ̈itsel tiyatro programı

\section{Makale Türï}

Araştırma Makalesi Öz

Bu çalışma eğitimde drama tekniklerinin “ötekinin” kabulü üzerindeki etkilerini inceler. Illgili literatür taraması ve dünya çapındaki çalışmaların karşılaştırılması eğitimde drama tekniklerini kültürlerarası eğitim kapsamında içeren tiyatro eğitim programı için gerekli teorik ve araştırma arka planını sağlamıştır. Eğitimde drama teknikleri farklı kültürel ortamlardan gelen öğrencilerin birbirlerini kabul etmelerini ve işbirliği yapmalarını teşvik etme amacıyla kullanılmıştır. Çalışmanın sonucunda; rol yapma ve ekip çalışması gibi eğitimde drama tekniklerinin “ötekinin” kabulü için uygun ortam oluşmasına ve projeye katılan öğrencilerin etkileşimi, iletişimi, işbirliği ve karşılıklı kabullenmesine katkı sağladiğı belirlenmiştir.

$1 \quad$ Ph.D., Department of Primary Education, University of Thessaly. Post-doctoral candidate, Department of Early Childhood Education, University of Thessaly, Greece. Email: dpannou@yahoo.gr. Orcid ID: 0000-0003-0683-1262.

2 Professor, Emeritus Department of Theatre Studies, University of Peloponnese, Greece. Email: alkistiseros@gmail.com. Orcid ID: 0000-0003-4342-7592. 


\section{Introduction}

The intercultural dimension in education has become necessary in Greece in recent years due to the changes which have occurred in the composition of the groups of students studying in Greek schools (Magos, 2013, p.199). At the same time, it has served as an incentive for the implementation of intercultural education aiming to create suitable conditions for achieving intercultural communication as a means of building and giving meaning not only to individual but also to collective identities (Govaris, 2011, p.175).

The ability to effectively communicate in cultural situations and to form relationships in a variety of cultural settings is characterized as intercultural competence (Bennett \& Bennett, 2001, 6) and has to do with the development of social skills concerning the acceptance and appreciation of "otherness" and with the creative management of its elements for the alteration of previously held positions and opinions (Magos, 2005, p.199). The following are characterized as dimensions of intercultural competence: a) intercultural sensitivity which focuses on positive emotions which contribute to the appreciation and respect of cultural differences, b) intercultural awareness which focuses on cultural self-awareness and culture specific awareness and c) intercultural relativism which focuses on flexibility, empathy and maintenance of identity (Chen \& Starosta, p.2008). As a result, the characteristics of intercultural competence concern emotional flexibility, individual autonomy, adaptability, open-mindedness and perceptual acuteness (Bennett, 2004).

In this specific framework, educational programs whose goal is to develop intercultural competence which aims at abolishing discrimination, achieving equality, mutual understanding, mutual acceptance and solidarity (Palaiologou \& Evangelou, 2003, p.74), adopt methods and practices which promote equal interaction as a means to acceptance of the "other" and the co-existence of students from different cultural backgrounds and concern intercultural activities which put into doubt stereotypes and prejudices (Magos, 2013, p.210).

\section{Theoretical Background}

Drama in Education (DiE) is an art form and a means of education based on current pedagogical principles and theories of teamwork, role-play and constructive learning and contributes to the development of social positions and values (Bolton, 1984; Heathcote, 1985; O'Neil, 1995; Alkistis, 2000; Tsiaras, 2007; Papadopoulos, 2010; Papaioannou, 2016).

As Alkistis states (2008, p.216), DiE can play a positive role in mastering the principles of intercultural education having to do with the promotion of intercultural empathy, solidarity and "intercultural" respect. Through the activities of DiE, students occasionally act out social norms and social interactions in which they are emotionally invested resulting in their learning empathy and in part discovering unknown aspects of their personalities through their individual performances while fulfilling the specific collaborative activities. The enactment of roles, characters and events requires the activation of knowledge and experience and the "unlocking" of emotions related to each case while at the same time leads to the exploration of a variety of social and emotional circumstances which the students themselves re-enact (Heathcote \& Bolton, 1995; Fleming, 2001; Neelands, 2008; Alkistis, 2008; Lenakakis, 2015 \& 2018; Tsiaras, 2016).

From the literature review it is seen that both abroad and in Greece, studies have been conducted at different educational levels with positive results regarding mainly the contribution of 
DiE techniques in the development of collective empathy, in acquiring intercultural competence, in managing conflicts, in intercultural communication, in intercultural sensitization, in assimilation of and co-existence of students in intercultural environments, in eliminating racist and "xenophobic" behaviors, in the acceptance of otherness and of different cultural "identities" (O'Toole \& Burton, 2002; Blight, 2003; Donelan, 2005; Gallagher, 2010; Letsiou, 2010; Giannouli, 2014; Mardas, 2016; Skaprentzou, 2016; Chaska, 2017).

At the same time, research programs have been conducted regarding a) the use of DiE techniques as a means of promoting cultural self-awareness and adaptability in intercultural schools (Alkistis, 2008, p.305-373); b) educational theatre programs for development of intercultural competence (Sextou, 2007, p.41-72) as well as c) didactic recommendations for using DiE techniques aimed at eliminating prejudices and at the acceptance of difference (Avdi \& Chatzigeorgiou, 2007, p.109-129, p.197, p.214).

In conclusion, it seems that the extended use of DiE in recent years and the place it has secured in the Primary Education Courses of Study as a distinct body of knowledge in our country, has rendered it widely accepted in the educational community (Papaioannou, 2016). Furthermore, extended use has contributed significantly to DiE being used in educational practice in the development of social skills related to the acceptance and appreciation of "otherness", in the creative management of its components for the alteration of previously held positions and opinions aiming at developing interpersonal relationships in the contemporary school and in the co-existence and interaction of students from different cultural backgrounds.

\section{Objective}

The objective of this research was the exploration of the effect of $\mathrm{DiE}$ techniques in the acceptance of the "other" in second grade students in primary school in Greece. The research questions posed for examination were:

a. Can the use of DiE techniques contribute to the interaction of students coming from different cultural environments?

b. Can the use of DiE techniques promote collaboration between students in an "intercultural" classroom?

\section{Methodology}

The present research is a case-study concerning the use of DiE techniques in the development of intercultural competence. The selection of the specific methodology was based on the fact that it provides the ability to observe social situations and capture their special characteristics and as a result is suitable for the observation of the characteristics of a specific classroom and for drawing conclusions regarding the effect of DiE techniques on the relationships of participating students (Cohen, Manion \& Morrison, 2008, p.314-315).

Sixteen (16) second grade students attending school in a semi-urban area in the county of Larisa, Greece participated in the study. It should be noted that the composition of the specific class was diverse with respect to the cultural background of the students. Specifically, the participants were comprised of five students of Albanian background, two Roma and nine native (Greek) students, a fact which created conflicts and a lack of cooperation between them in group activities. In this qualitative 
social study, the socio-cultural features of a singular case of students were examined with a view to interpreting and analyzing the social framework of the specific classroom (Iosifidis, 2008, p.59-60).

Data was collected through the use of participatory observation utilizing journal notes and through the composition of written texts by the students. Specifically, participatory observation, which is suitable for systematic observation of social behavior in the "natural" environment where that behavior occurs (Iosifidis, 2008, p.126), concerned the documentation and evaluation of the characteristics of the learning environment in relation to the interaction and level of collaboration of the students during the implementation of the educational theatre program (Cohen, Manion \& Morrison, 2008; Mason, 2003). The composition of texts in the form of letters was used with a view to documenting the opinions and perceptions which arose from the collaboration of the students during the implementation of the DiE activities with respect to the subject of the literary texts regarding the acceptance of "otherness" and of the "other" (Avdi \& Chatzigeorgiou, 2007, 96; Papadopoulos, 2010, p.255-257).

\section{Description of the Educational Theatre Program}

The educational theatre project was conducted in 2017 within the frame of the Flexible Zone Program and lasted 3 months, from February through April, during which twelve (12) interventions were implemented. The program was carried out in two phases. In the first phase, the students carried out activities and played games to enable them to become acquainted, build trust, collaborate and communicate ("Name with movement", "Name with adjective", "Your hand, please", "Mirrors", "Guiding the blind", "Dancing blind", "Little train", "Together we stop - together we start"). The specific activities were conducted with the aim of creating a suitable environment to achieve communication and collaboration between the native students, the Roma and the students of Albanian heritage in an experiential and playful way (Alkistis, 1998; Govas 2002; Tsiaras, 2016).

In the second phase, literary texts from the $1^{\text {st }}$ and $2^{\text {nd }}$ Grade Readers of primary school, The Dolphin, were used (Tsilimeni, Grekos, Kaisaris \& Kaplanoglou, 2002) regarding the acceptance of diversity. The use of literary texts with intercultural content contributes to the positive attitude of students with respect to the "other", in abolishing prejudices related to cultural, ethnic, linguistic and religious differences and can be used in educational practice with a view to understanding social and cultural attitudes and perceptions which are consistent with the principles of intercultural education (Chondolidou, 2002, 118-119; Paparousi, 2007; p.201- 212; Avdi \& Chatzigeorgiou, 2007, p.125129, p.197-199, p.214-223; Magos, 2012; Zogaki, 2017).

Giving meaning to literary texts may be achieved, according to the Literature Course of Study (P.S. 2011), through the techniques of DiE. In addition, positive results were achieved in studies which used DiE activities for an approach to literary works aimed at the students' understanding, assigning meaning to and responsiveness in relation to the issues raised in the literary texts (Papadopoulos, 2004 \& 2006; DeBlase, 2005; Katsaridou, 2011; Devlin, 2013; Weng, O’Toole \& Sinclair, 2013; Papaioannou, 2016).

In the specific framework and according to the commonly accepted point of view - as stated above, that DiE techniques may contribute to the co-existence and positive interaction of students coming from different cultural backgrounds - the students of the specific class approached the literary texts presented below through the aforementioned experiential and teamwork activities. 
In the first literary text, " $S$ " as in swordfish by Maria Frangia (Tsilimeni, Grekos, Kaisaris \& Kaplanoglou, 2002, p.35-36), the author combines imaginary and real elements related to attending school and focuses on the acceptance of diversity. The protagonist of the story, a small swordfish, is not accepted by his classmates and often receives critical comments from them resulting in his not wanting to go to school until an unexpected event turns him a hero as he saves his classmates and teacher from a huge net. The approach to the literature was carried out through the following techniques: "Teacher in Role", "Conscience Alley", "Gossip Circle", "Time Machine”, "Interviews", “Composition” (Papadopoulos, 2010, p.247-274; Alkistis, 2008, p.260-269; Avdi \& Chatzigeorgiou, 2007, p.86-96).

In the second literary text, Give love by Angeliki Varela (Tsilimeni, Grekos, Kesaris \& Kaplanoglou, 2002, 107-108), the author refers to mutual acceptance and the development of friendships among students attending an intercultural school. She inventively utilizes the organization of a celebration in the classroom, a celebration about friendship with a view to the students exchanging presents amongst themselves. During the celebration, the gift that stands out is that of a student of Polish background who gives each of his classmates an apple telling them to "Give love the way you give an apple, so simply." The approach to the literature was carried out through the following techniques: "Role Play", "Frozen Picture", "Television Show", "Circular Drama", "Team Dialogue", “Composition” (Papadopoulos, 2010, p.247-274; Alkistis, 2008, p.260-269; Avdi \& Chatzigeorgiou, 2007, p.86-96).

It should be noted that the students, as stated before, produced texts in the form of letters addressed to the central character of each story that was approached through the DiE activities (Avdi \& Chatzigeorgiou, 2007, p.96; Alkistis, 2008, p.288; Papadopoulos, 2010, p.255-258). In addition, it is noted that after the completion of the DiE activities of each intervention, a discussion occurred aimed at reflection upon and expression of the thoughts and perceptions of the students in relation to the subject addressed by each literary work (Alkistis, 2008, p.281 - 291).

\section{Results}

From the participatory observation and the documentation of "social" behaviors of the participating students during the educational theatre project (Iosifidis, 2008, p.127), it arose that during the first interventions of the implementation of the get-to-know, trust, collaboration and communication games and activities, the students sought to participate in teams comprised of students having their same ethnic background. It should be noted that the students were free to choose which team they wanted to join in order to implement the aforementioned activities, a fact which provided them a great degree of freedom but which simultaneously made the selection criterion of the team members based on their Greek or Albanian background clear and resulted in many instances in the marginalization of the Roma students with respect to the other groups. Following the educational theatre program, after the interventions concerning the approach of literary works with intercultural content were implemented through use of $\mathrm{DiE}$ techniques, the composition of the teams gradually began to change. Initially teams were formed wherein either Roma and native students participated or native students and Albanian background students participated but later on teams were formed comprised of Roma, native and Albanian background students. As a result, the DiE techniques created the appropriate environment and positive atmosphere to enable the collaboration and the 
interaction amongst all the students. This suggests that through the specific activities, the students accepted their different cultural identities and operated as members of the specific social framework they found themselves in, in other words, of the specific "intercultural" classroom.

From the analysis of the texts (Iosifidis, 2008, p.147) written by the students in the form of letters, as stated above, two categories of analysis arose. The first concerns the acceptance of linguistic and ethnic difference and of the "other" and the second concerns intercultural sensitivity and emotional flexibility regarding the "other". With respect to the first category, we indicatively cite some of the verbal accounts the students used in the letters they wrote: "Dear Janus, it does not bother me that you are from Poland", "Dear good friend, Janus...", "Dear Friend...", "Dear swordfish....", "My dear friend, swordfish.....", "I don't care that you are from another country", "I don't care that you are from Poland. I can show you the sights of my city", "It does not bother me that you are from another country and I want to become friends", "I don't care that your background is from another country, do you want to play together?", "Let's go...to new countries", "In school you will find new friends", "You will have a very good time in Greece", "You will learn Greek", "I would like you to stay in Greece", "I know you don't speak Greek well but do you want to be friends?", "I want you to be my classmate", "You are one of the best friends I have made so far", "We will sit together", "Because you are different from us, you saved us!!!”, "Your nose made you a hero!", "Dear swordfish, I want us to become friends and I don't care that you are not like me", "I don't mind that you have a big nose, I want us to become friends", "You don't have to feel bad because you are different since you are a hero", "We will always hang out", "I want us to play together", "I want us to be in the same class", "We want you in our school with us", "I want us to be best friends".

With respect to the second category, we indicatively cite some of the verbal accounts the students used in the letters they wrote: "I was so pleased with your gift, it was wonderful", "We thank you for your gift and that you are so generous", "I would like to give you a gift as well", "I really liked it that you gave everyone apples", "I have to say 100 thanks", "I will introduce you to my school", "Do you want to be friends?", "Your behavior was very good", "I also got you an excellent gift", "If you have time, come to the game at 8.30. You will also play", "Thanks for saving us", "You are my hero", "We will never make fun of you again", "Sorry for making fun of you", "We love you very much", "I am sorry for making you sad", "I will not laugh at you”, "Will we go eat candy?", "We will go for walks", "Every weekend, we will go on excursions", "I want us to hang out because I don't want you to be alone", "Do you want us to teach you Greek?", "You can become the leader of the class", "We will go to the amusement park together", "I will throw you a party", "Do you want to play volleyball?", "Do you want to come to my house?", "I want us to become friends because you are a very good kid", "With many kisses, your friend Elena/Vayia”, "With appreciation, Eutichia/Denis", "With love, Katerina/Meggie”, "Your friend, Antonis/Marinos”, With love, your friend, Adem/Vasilis".

From the results of the analysis of the texts, it appears that approaching literary works with intercultural content through $\mathrm{DiE}$ techniques contributed to the understanding of the messages relayed by the literature through the experiences of the characters referred to therein and simultaneously positively influenced the acceptance of the "other" by the students who participated in the theatrical education program. 


\section{Conclusions}

Based on the results, the educational theatre program had a significant effect on the acceptance of the "other" by the second grade students of the primary school. The results of the present study are in agreement with the respective conclusions of similar studies in which DiE techniques were used with the aim of achieving intercultural competence, conflict management, assimilation and coexistence of students of different cultural backgrounds and the acceptance of otherness and diversity and different cultural "identities" (O'Toole \& Burton, 2002; Blight, 2003; Conrad, 2004; Donelan, 2005; Letsiou, 2010; Giannouli, 2014; Magdas, 2016; Skarpentzou, 2016; Zourdou, 2017; Chaska, 2017).

Moreover, from the interpretation of the qualitative analysis of the data, it was determined that the use of DiE techniques positively influenced the mutual acceptance and collaboration of the students attending the specific "multi-cultural" classroom. Specifically, from the participatory observation and the documentation of the characteristics of the learning environment, it arose that the students interacted and collaborated during the DiE activities, which suggests that the specific activities contributed to the creation of a suitable environment to achieve mutual acceptance among the native students, those of Albanian background and Roma students.

Likewise, from an informal discussion that occurred with the responsible educator of the specific class, it arose that not only during the educational theatre program but also after its completion, the "atmosphere" in the classroom improved with respect to the students' relationships in that the conflicts between them were minimized and the level of their cooperation during group activities increased.

In addition, from the interpretation of the analysis of the contents of the texts, it arose that the said educational theatre program contributed to the acceptance of linguistic and ethnic difference and of the "other" as well as to intercultural sensitivity and emotional flexibility with regard to the "other". As a result, the project contributed to the development of the features and dimensions of intercultural competence (Bennett \& Bennett, 2001, p.6; Magos, 2005, 199; Chen \& Starosta, 2008).

In conclusion, interpreting the results of the present study, it seems that the utilization in the educational practice of educational theatre programs a) aimed at mutual understanding, mutual acceptance and in the solidarity of students attending "multi-cultural classes" (Paleologo \& Evangelou, 2003, p.74) and b) which adopt experiential and collaborative group methods as a means of accepting the "other" and the co-existence of students from different cultural groups (Magos, 2013, p.210), can be effective intercultural undertakings which will positively impact the promotion and acquisition of intercultural competence of the participating students. 


\section{References}

\section{English}

Bennett, J.M \& Bennett, M.J. (2001). Developing intercultural sensitivity; an integrative approach to global and domestic diversity. Retrieved January 28, 2019, from http:// doku.cac.at/dmis bennett_2001.pdf

Bennett, M.J. (2004). Becoming interculturally competent. In J.S. Wurzel (Ed.), Toward Multiculturalism: A Reader in Multicultural Education, 62-77. Newton, MA: Intercultural Resource Corporation.

Blight, R. (2003). More than words - A passionate vision: Building cultural and communication competence through drama/theatre. Applied Theatre Researcher/IDEA Journal, 4, Article 10.

Bolton, G. (1984). Drama as education. London: Longman.

Chen, G.M. \& Starosta, W.J. (2008). Intercultural communication competence. A Synthesis. In M.K. Asante, Y. Miike, \& J. Yin (Eds.), The Global Intercultural Communication Reader, 215-217. New York: Routledge.

Conrad, D. (2004). Exploring risky youth experiences: Popular theatre as a participatory, performative research method. International Journal of Qualitative Methods, 3 (1), Retrieved January 26, 2019, from http:// journals.sagepub.com/doi/10.1177/

DeBlase, G. (2005). Teaching literature and language through guided discovery and informal classroom drama. The English Journal, 95(1), 29-32.

Devlin, M. (2013). To play or not to play: Using drama as effective pedagogical tool to teach literature. Senior Honors Theses. Paper 367. Eastern Michigan University, Honors College. Retrieved from http:// commons.emich.edu/honors $/ 367 /$

Donelan, K.J. (2005). The gods project: Drama as intercultural education: An ethnographic study of an intercultural performance project in secondary school. PhD Thesis, Griffith University, Retrieved on January 27, 2019, from http://web.education.unimelb.edu.au/curriculumpoliciesproject/1975-2005/

Fleming, M. (2001). Teaching drama in primary and secondary schools. An Integrated Approach. London: David Fulton.

Heathcote, D. (1985). Collected writings on education and drama. London: Hutchinson.

Heathcote, D. \& Bolton, G. (1995). Drama for learning: Dorothy Heathcote's Mantle of the Expert Approach to education. Portsmouth: Heinemann Press.

Magos, K. (2012). The princess is a racist. Combating stereotypes through teaching folktales. An actionresearch project with young children. In N. Palaiologou and G. Detz (Eds), Mapping the Broad Field of Multicultural and Intercultural Education Worldwide (pp. 195-208). Cambridge: Cambridge Scholars Publishing.

O’Neil, C. (1995). Drama worlds: A Framework for process drama. Portsmouth: Heinemann.

O’Toole, J. \& Burton, B. (2002). Cycles of harmony: Action Research into the effects of drama on conflict management in schools. Applied Theatre Researcher, 3, 1-6. Retrieved April 22, 2019, from https:// research-repository .griffith. edu.au/handle/10072/6616/

Weng, C., O'Toole, J. \& Sinclair, C. (2013). Invigorating literature teaching in Taiwan through drama. The Asian Conference on Education, Official Conference Proceedings Osaka, Japan. Retrieved on January 29, 2019, from http://www.iafor.org 


\section{Greek}

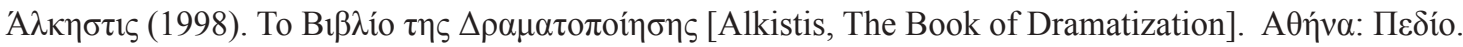

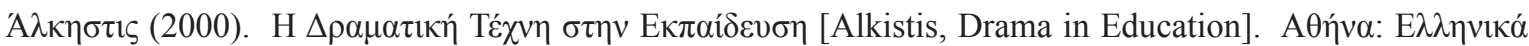
Гро́ $\mu \mu \alpha \tau$.

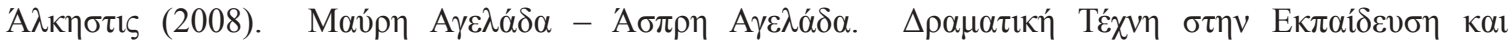

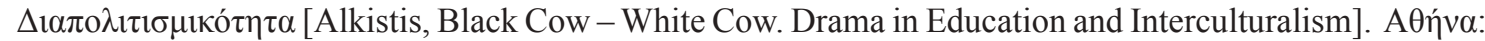
Тómos.

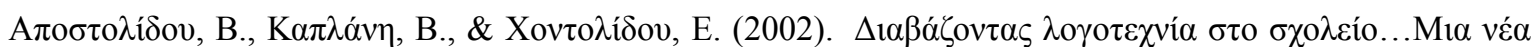
$\pi \rho \tau_{\tau \alpha \sigma \eta} \delta เ \delta \alpha \sigma \kappa \alpha \lambda i ́ \alpha \varsigma$ [Apostolidou, V., Kaplani, V. \& Chontolidou, E., Reading Literature in School......A

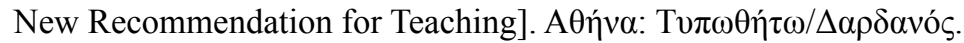

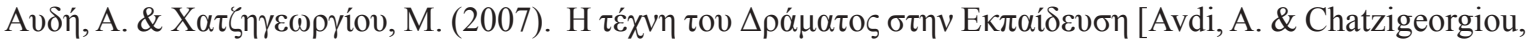

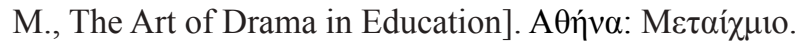

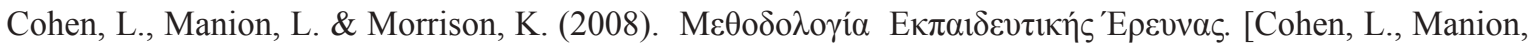

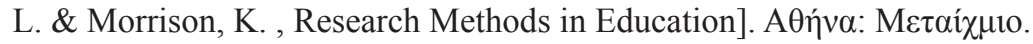

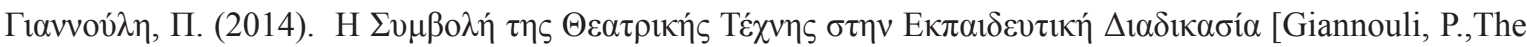

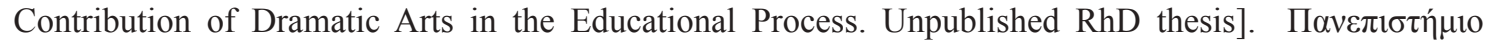
Aıraíov.

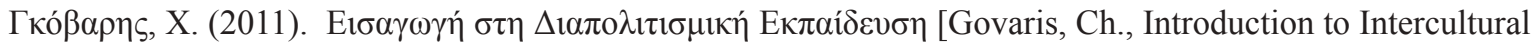
Education]. A $\theta \eta ́ v \alpha: \Delta \iota \alpha ́ \delta \rho \alpha \sigma \eta$.

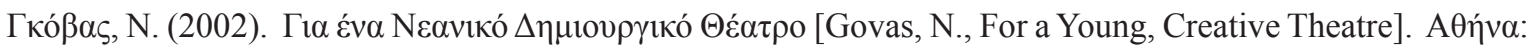

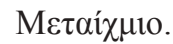

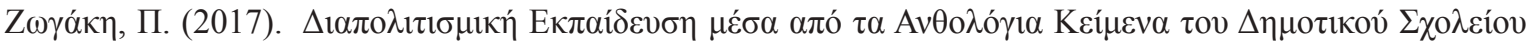
[Zogaki, P. Intercultural Education through the Collected Literary Texts of Primary School. Postgraduate dissertation]. University of Ioannina.

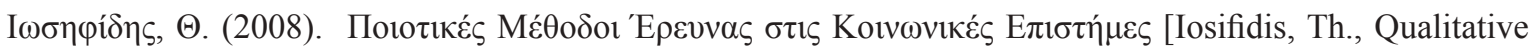

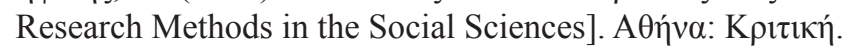

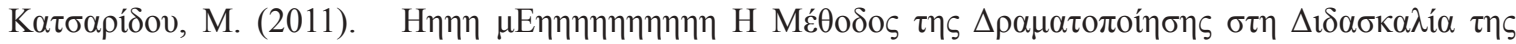

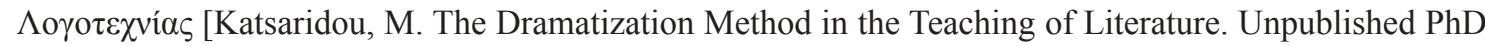

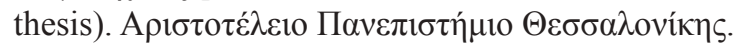

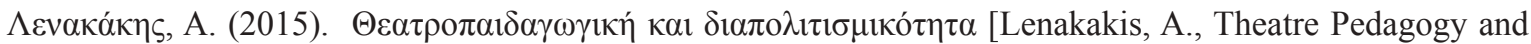

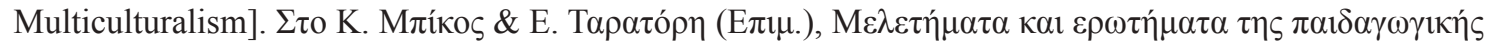

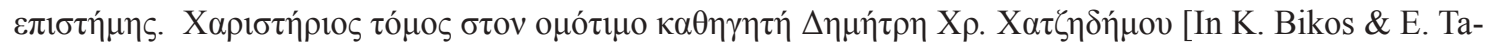
ratori (Eds Studies and Questions of Educational Science. Gratitude Volume to Professor Emeritus Dimitris

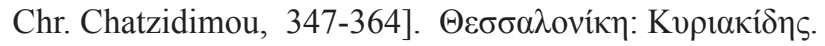

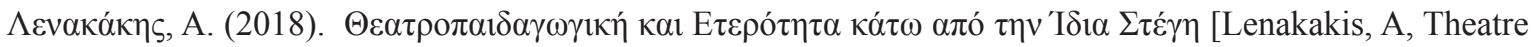

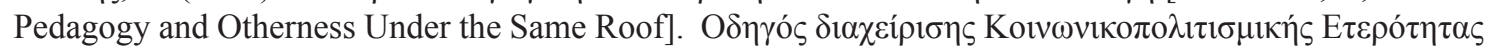

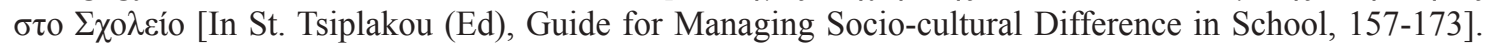
Nicosia, Cyprus: Ministry of Education and Culture, Cyprus Pedagogical Institute. Retrieved January 30, 2019, from http://mefesi.pi.ac.cy/files/docs/users/zapiti.a/Odigos2.pdf

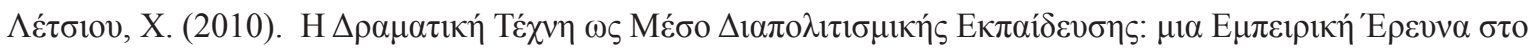

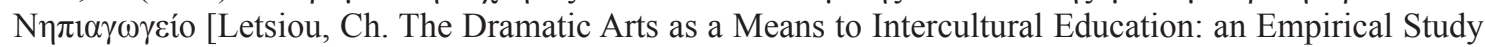

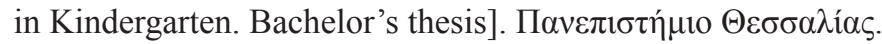

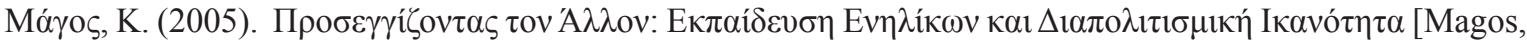
K., Approaching the Other. Adult Education and Intercultural Competence]. In Minutes (CD-ROM) of the $2^{\text {nd }}$ International Conference of the Hellenic Adult Education Association: "Adult Education \& Social

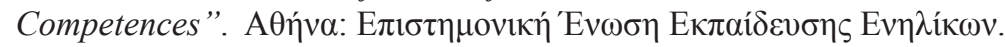




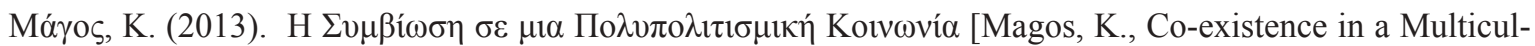

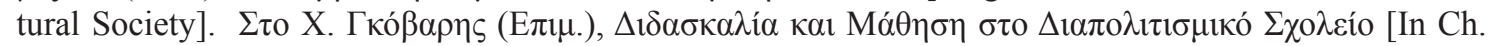
Govaris (Ed), Teaching and Learning in the Intercultural School, 199-222]. A01́va: Gutenberg.

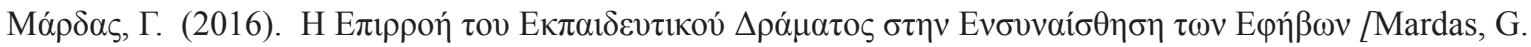

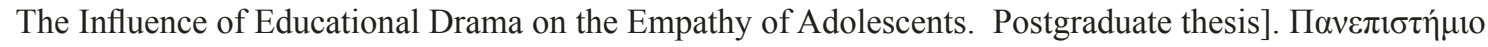

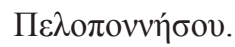

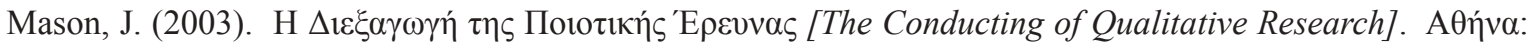

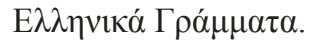

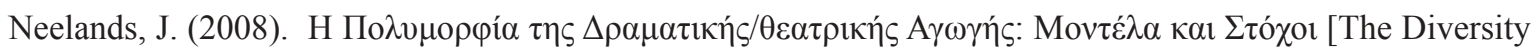

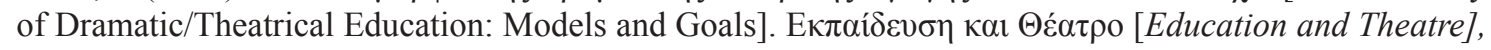
9, 58-66.

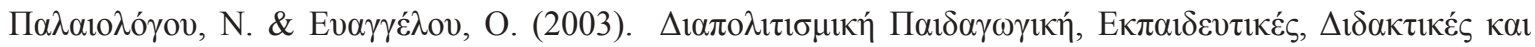

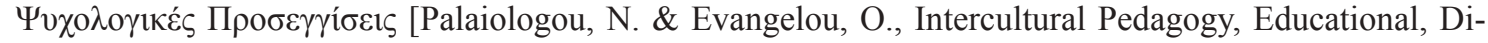

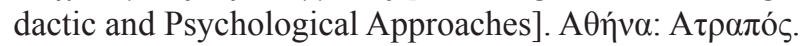

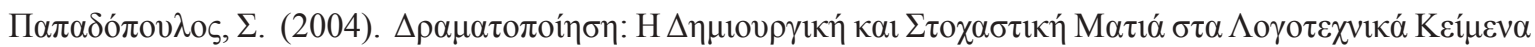

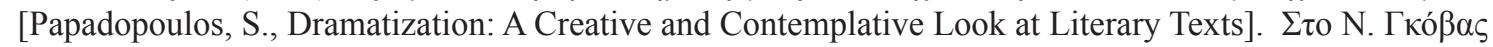

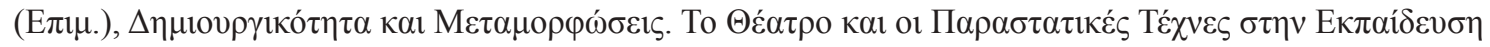
[In N. Govas (Ed), Creativity and Transformations. The Theatre and the Performing Arts in Education,

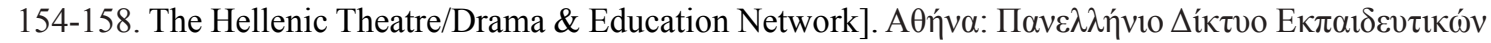

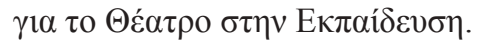

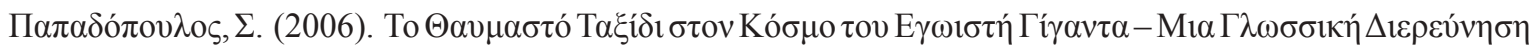
$\sigma \varepsilon \Delta \rho \alpha \mu \alpha \tau \iota \kappa o ́ ~ П \varepsilon \rho \iota \beta \alpha ́ \lambda \lambda o v$ [Papadopoulos, S.,The Wonderful Journey in the World of the Egotistical Giant

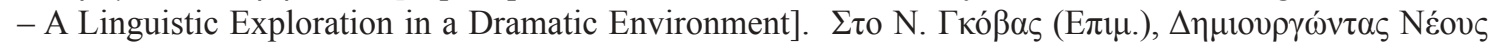

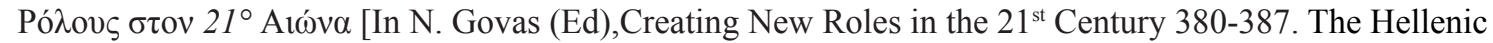

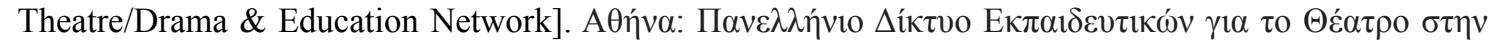

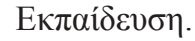

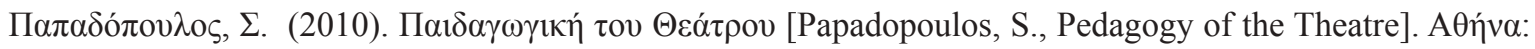

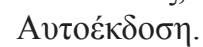

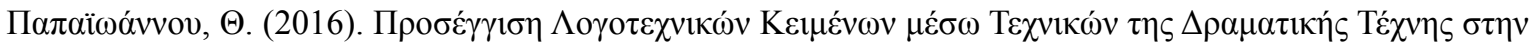

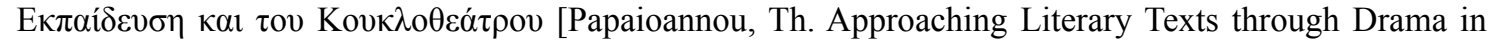

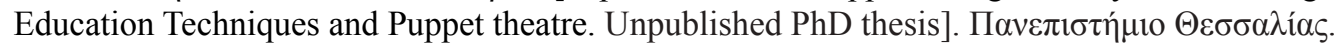

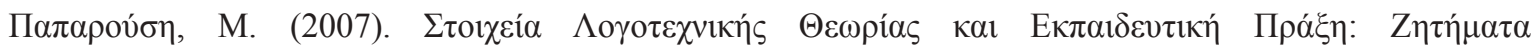

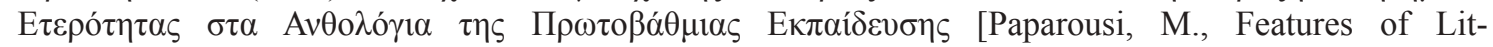
erary Theory and Educational Practice: Issues of Otherness in the Readers of Primary Educa-

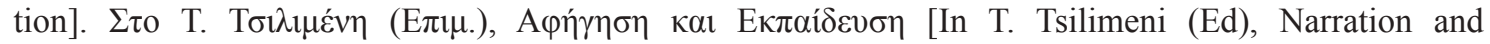
Education, 197-212. Volos: Laboratory of Language and Culture, University of Thessaly, Volos,

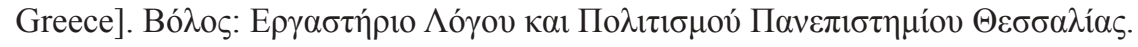

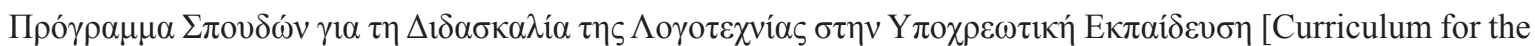

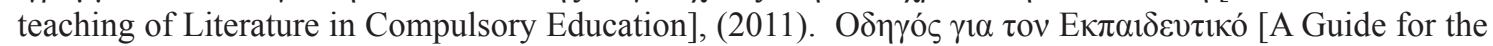

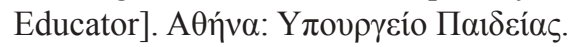

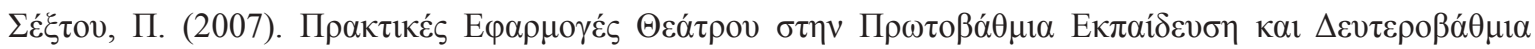

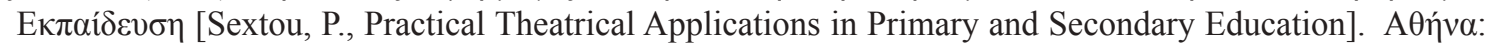

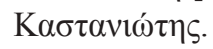

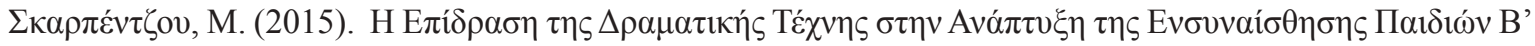

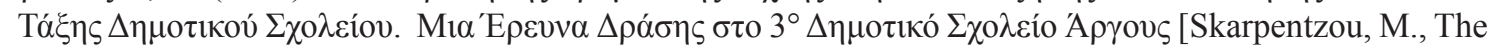
Effect of Dramatic Arts in the Developments of Empathy of Children in $2^{\text {nd }}$ Grade of School. An Active

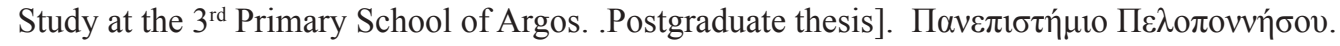




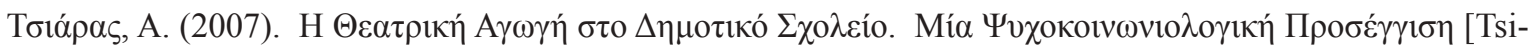

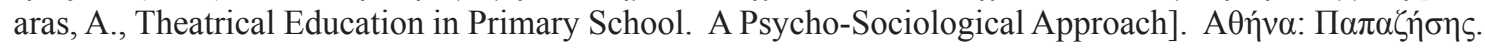

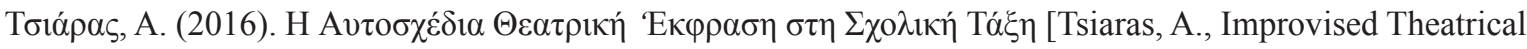

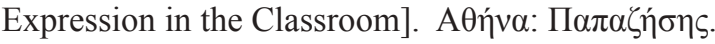

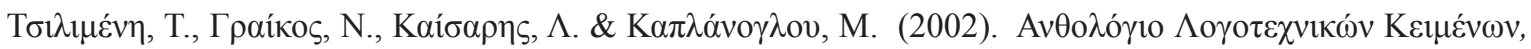
To $\delta \varepsilon \lambda$ pívı [Tsilimeni, T. Grekos, N. Kesaris, L. \& Kaplanoglou, M., A Collection of Literary texts, The

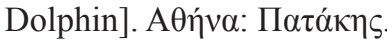

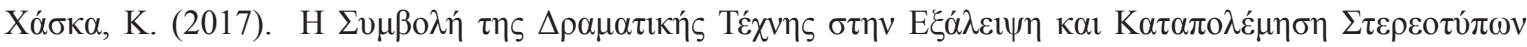

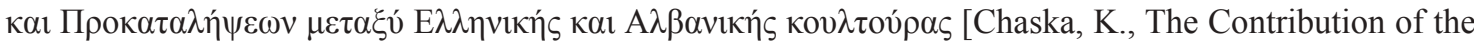
Dramatic Arts in the Elimination and Combating of Stereotypes and Prejudices between the Greek and

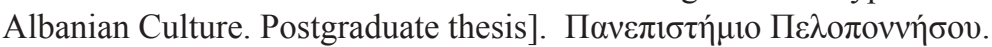

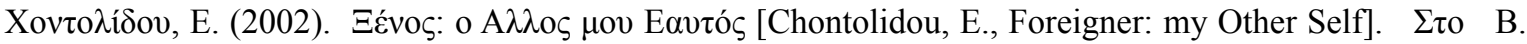

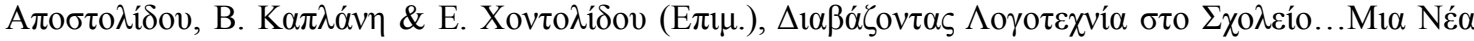
Прó $\alpha \sigma \eta \Delta \mathrm{t} \delta \alpha \sigma \kappa \alpha \lambda i \alpha_{\varsigma}$ [In V. Apostolidou, V. Kaplani \& E. Chontolidou (Eds), Literature in School.....A

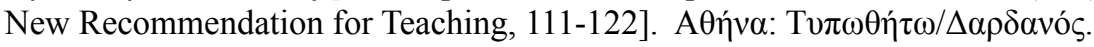





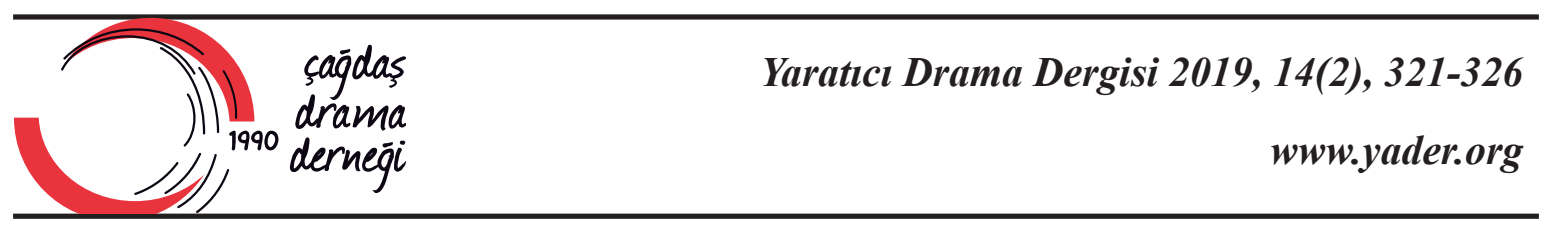

\section{Working in Role: Teachers and Children}

\section{Patrice Baldwin ${ }^{1}$}

\begin{tabular}{|c|c|}
\hline Article Info & Abstract \\
\hline DOI: $10.21612 /$ yader.2019.019 & $\begin{array}{l}\text { Drama as a learning medium, has its roots in dramatic play. Very young babies naturally } \\
\text { imitate and mimic what they see and hear. Once they are able to move around, toddlers }\end{array}$ \\
\hline Article History & start trying out things that they have seen adults doing. For example, they might \\
\hline Received & pretend to cook, make imaginary cups of tea, drive imaginary cars and motorbikes, \\
\hline 24.05 .2019 & $\begin{array}{l}\text { pretend they are talking to someone on a mobile phone, etc. They sometimes use } \\
\text { functional toys in their dramatic play, e.g. a toy teapot 'as if' it were a real teapot, } \\
\text { but they also use ambiguous obiects imaginativelv 'as if' thev are something else. }\end{array}$ \\
\hline Keywords & For example, a cardboard box might become a car, a stick might become a knife. \\
\hline Working in role & They often bring in dolls, furry toys, their pets or imaginary friends into their role- \\
\hline Teacher in role & play scenarios, as the other characters. Children will also role-play together and \\
\hline Teacher & sometimes with adults. The role play is not real but the skills being developed are \\
\hline Children & $\begin{array}{l}\text { real, e.g. co-operation, collaboration, turn taking, negotiation, listening, fine motor } \\
\text { skills, etc. Whilst imitating, mimicking and improvising, they are using real language } \\
\text { purposefully, within a range offamiliar or newly imagined contexts. They feel confident }\end{array}$ \\
\hline Article Type & and successful in their make believe worlds and are often rehearsing adult situations \\
\hline The Letter of Opinion & $\begin{array}{l}\text { and activities. Young children in schools get time in role play areas (both indoors and } \\
\text { outdoors). They sometimes have teachers and/or other adults interacting with them } \\
\text { as they role play but they also should have opportunity for their own, free role play } \\
\text { without adults involved. A teacher (or other adult), role-playing with children can } \\
\text { help focus and maintain children's attention, model various types of talk, give status } \\
\text { to their make believe and introduce problems to be resolved together. Teachers in role } \\
\text { can stimulate and challenge the children's various types of thinking and inter-thinking, } \\
\text { from within an engaging and compelling fiction }\end{array}$ \\
\hline
\end{tabular}

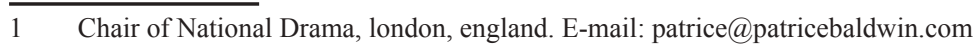




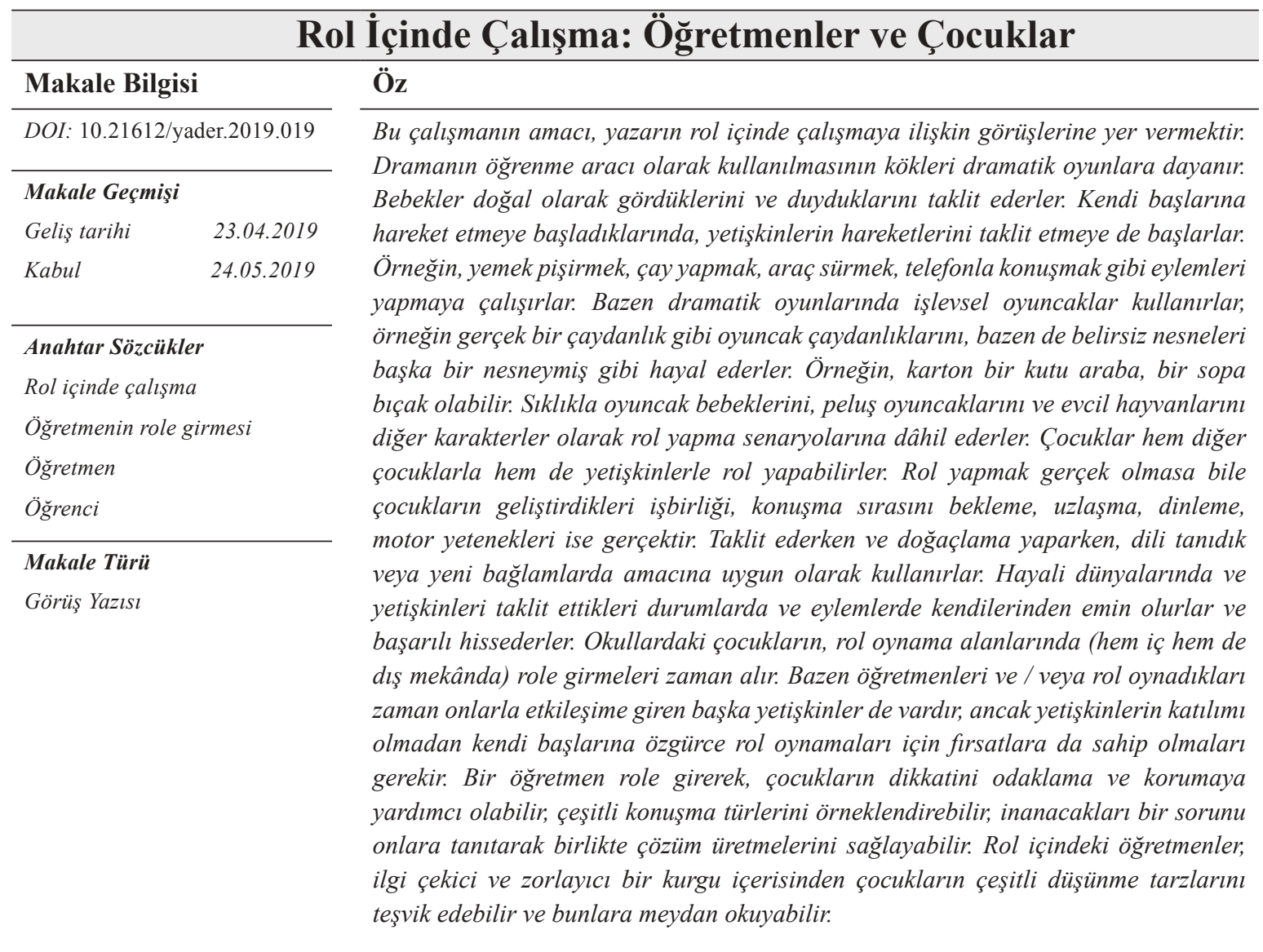


Drama as a learning medium, has its roots in dramatic play. Very young babies naturally imitate and mimic what they see and hear. Once they are able to move around, toddlers start trying out things that they have seen adults doing. For example, they might pretend to cook, make imaginary cups of tea, drive imaginary cars and motorbikes, pretend they are talking to someone on a mobile phone, etc. They sometimes use functional toys in their dramatic play, e.g. a toy teapot 'as if' it were a real teapot, but they also use ambiguous objects imaginatively, 'as if' they are something else. For example, a cardboard box might become a car, a stick might become a knife. They often bring in dolls, furry toys, their pets or imaginary friends into their role-play scenarios, as the other characters. Children will also role-play together and sometimes with adults. The role play is not real but the skills being developed are real, e.g. co-operation, collaboration, turn taking, negotiation, listening, fine motor skills, etc. Whilst imitating, mimicking and improvising, they are using real language purposefully, within a range of familiar or newly imagined contexts. They feel confident and successful in their make believe worlds and are often rehearsing adult situations and activities.

Parents, teachers and teaching assistants sometimes choose to join in children's dramatic role-play. They are hopefully alert to the many learning opportunities that arise, and to ways they can raise the level of challenge from within the shared, imagined scenario. Adults may choose to deliberately plant learning opportunities. For example, an adult might enter the child's pretend café as a customer and eat a pretend meal, but then announce that their purse has gone missing and they can't pay for the meal? How will the child in role as a café owner, deal with this unexpected situation? The scenario in the café is not real but it feels as if it is and the situation requires and rehearses real problem solving skills.

Young children in schools get time in role play areas (both indoors and outdoors). They sometimes have teachers and/or other adults interacting with them as they role play but they also should have opportunity for their own, free role play without adults involved. The theme of the role play area in a classroom will be changed from time to time. Often the children help set up the role play area and bring items in for it (sharing ownership of it). For a few weeks it might be a travel agents, with brochures of unfamiliar places. The teacher might enter as a customer who has not decided where to go on holiday. The child presents some possibilities and answers the customer's questions. Next the role play area might become a hospital with bottles, bandages, stethoscopes etc. and the adult might become a new nurse on her first day, who needs training.

Adults should not take over children's self-initiated role - play. They should initially observe and listen to the children interacting in role. It will reveal much about various children's personal, social, emotional and language development, as well as indicate where their interests lie and reveal something of their real life experiences. A teacher (or other adult), role-playing with children can help focus and maintain children's attention, model various types of talk, give status to their make believe and introduce problems to be resolved together. Teachers in role can stimulate and challenge the children's various types of thinking and inter-thinking, from within an engaging and compelling fiction.

\section{Moving from Dramatic Role-play to Whole Class Drama}

An adult as co-participant in dramatic play, can pave the way for using 'teacher in role' in schools. Teachers in role, interacting within a whole class Drama, can be effective at any age. 
Dramatic play, Drama for Learning, Process Drama and Theatre all involve pretending 'in role' together.

It is perfectly possible for teachers to do drama lessons with children and yet never go into role themselves but I would encourage all teachers to have a go at 'Teacher in Role'. Interacting with a teacher in role, is very engaging for children and any associated learning becomes emotionally tagged and highly memorable.

Teachers without drama training, may be understandably nervous about trying 'Teacher in Role' with whole classes but hopefully the following tips and 'rules' will increase their confidence and help them get started. When class teachers see how compelling working in role with children can be, they are likely to add it to their teaching repertoire for any age group.

\section{'Teacher in Role' (Some Tips and Guidelines)}

1) Make sure the children know in advance, that you are going to be a 'Teacher in Role'

Don't just start behaving differently and expect them to guess you are in role. Tell them just before, that you will be going into role. You might start by just being in role for a minute or two. You can always step out of role, talk to them again as their teacher, and then go back into role again. However you must ....

\section{2) Always make it clear to the children, when you are in or out of role}

It might be helpful to 'sign' the role in some way, maybe wearing a simple piece of costume or prop, e.g. 'When I am carrying this notepad, I am the reporter. When I put it down again, I am no longer the reporter.' Or, you could simply say that you will walk away from them and that when you turn around and come back again, you will be a reporter.

\section{3) Maintain seriousness and commitment, whilst you are in role}

You need to maintain the role, with confidence and commitment. Try not to communicate any nervousness or embarrassment. You need the children to work with you in role seriously and confidently, so you need to model that. If you show nervousness or are half-heartedly in role, then the children might feel a bit uncomfortable about interacting with you in role.

\section{4) Decide the main purpose of your 'teacher in role'?}

You need to know why you are taking on a role at any particular point in the drama and what you want to achieve with the role, in terms of the children's thinking and learning. Before you take on a role, you should have the purpose and function of the role clearly in your mind and keep it in mind.

\section{5) What are the main types of role that you might choose from?}

You can define roles in various ways. For example, they can be defined in terms of their status and/or purpose. Most roles are a combination of types, e.g. you could take on a low status information gathering role, or a high status, information giving role, etc.

High Status roles: Teachers who are not used to working in role, sometimes opt too often for 'high status' roles, which helps the teacher to feel secure and in control of children's behaviour. Over use of high status 'teacher in role', is not particularly enabling for the children. If they are usually obeying a teacher in role and following instructions, then this is quite limiting. The teacher needs to 
be an enabler, catalyst, mediator and facilitator of drama as a learning experience not just a director, with the children as their puppets.

You can challenge high status role stereotypes by taking on apparently high status role but in a way that lowers the status and surprises, e.g. you might take on the role of a King but confide in the children (your most trusted servants), that you don't really like being a King and are having nightmares about a hostile neighbouring King. You are frightened and tired and need their advice and help. Now the king's strong and faithful servants are empowered to make suggestions to their weak king, diplomatically.

A high status 'Teacher in role', can be used provocatively to stir up the children in role. The teacher in role can then withdraw for a while, to give the children the opportunity to speak freely about the protagonist. For example, in a drama about two countries (rich and poor), the rich King (teacher in role) can be rude to the poor arrivals, seeking food and shelter (the children in role) and then walk away.

Low status roles: Children will usually rise to the occasion, when they see that someone in role (especially the teacher), needs their help. If you give children roles with assumed knowledge and responsibility, the children will start to feel empowered and will usually rise to the occasion. Mantle of the Expert (which comes under the umbrella of Drama for Learning) is built around this.

I was once a 'teacher in a role' as a low status troll. My job was to stop goats from crossing a bridge to eat the grass. The grass had rare flowers in it. I was not managing to stop the goats, as they were hungry and ignored me. A group of children were in role as my employers. They told me that I was no good at my job and they sacked me! I explained that I really needed the job. I had a family to feed and rent to pay. They had not expected me to prick their consciences in this way and make sacking me more difficult for them. They told me that I could get another job. I explained that I could not read or write. I only knew about flowers. I asked them if they could find a different job for me? They discussed this and decided that I could have a flower stall outside a school. I could sell my flowers and they would ask the school to teach me to read and write, so that I could then apply for other jobs in the future. In drama, the children may have high status roles and make decisions but the teacher needs to then ensure, that they consider the consequences of their decisions.

Intermediary roles: An example of an intermediary role, would be a teacher in role as a messenger from a higher authority. For example, the people who live in Hamelin are plagued by rats. The children are in role as the people who live in Hamelin. The teacher in role as the messenger, has been sent by the Mayor to listen to their complaints. The messenger can listen sympathetically to the people. The messenger has no power. He is just doing his job, gathering information for the Mayor. Rational discussion is more likely to happen, if the townsfolk are talking with a sympathetic intermediary.

Of course the Mayor's messenger could be played differently. He might be the intermediary who takes back the people's messages to the Mayor but is very detached or unsympathetic.

Equal status roles: You can be in the same role as the childrenFor example, you could be just a citizen of Hamelin. You are all deciding together, what to do about the rats and the Mayor. From an equal status position, you can still gather or give information. You can still be compliant or provocative, as different villagers will have different personalities and may have different opinions and viewpoints. 
Information giving roles: A main function of 'teacher in role' is often, to add more information to the Drama. In a drama lesson based on historically true events, i.e. the evacuation of children from London during World War 2, the teacher could take on the role of a government official, giving out copies of the government information leaflets and explaining why parents should send their children to the countryside. Real historical information is being imparted to children by the teacher in role.

Teachers might also decide to take on information giving roles in an entirely fictitious drama, e.g. the teacher is in role as the captain of a Spaceship on a secret mission. The captain tells the children that they are all experts in various fields. They have been invited to be members of a team that will set off together, on an exploratory mission to a distant planet. Selected humans might be able to live there in the future. What questions would they like to ask the captain before committing?

Information gathering roles: If the children have information they have acquired and can pass on within a drama, then the teacher can give themselves the role of someone who wants to know that information. For example, if the children are archaeologists in Egypt with Howard Carter, waiting for Lord Caernarvon to arrive before opening the tomb (Tutankhamun's), then they might talk secretly to the press (teacher in role), telling them what they know at this point. This enables the teacher to assess their current knowledge and understanding by asking the children questions and getting them to elaborate. Or maybe the teacher is a visitor to a village with a resident dragon. The visitor would have plenty of questions to ask and the children would answer them creatively together, building their storydrama collectively.

Very few roles will fall completely into one category. When you are giving information in role, you are likely to also be gathering information too, intentionally or otherwise.

\section{6) How long do you stay in role for?}

You only stay in role, for as long as it necessary for the purposes of the children's learning and the drama itself. Once the role has fulfilled its function and purpose, you come out of role. You can return in role if and when necessary. You can also take a different role at another point in the drama, if there is a purpose in doing so, e.g. returning as someone different, who was not present in an earlier scene and asking the children to tell you in role, what happened. This can be a way of giving them practice at recounting events, checking that they all agree and understand what has happened in the drama, before moving on. 


\section{Yaratıcı Drama Dergisine İlişkin Açıklamalar ve Yazım Kuralları}

\section{Yaratıcı Drama Dergisi’ne Yayımlanmak üzere gönderilen yazılar:}

1. İlk olarak iThenticate ya da Turnitin gibi intihal programları ile taranır ve alıntı oranı \% 15 altında olan çalışmalar alana uygunluk açısından öncelikle editör tarafından incelenerek yayın kuruluna iletilir. Yayımlanmasına karar verilen yazılar, bilimsel açıdan değerlendirilmek üzere en az iki hakem tarafindan incelenir.

2. Hakem raporlarından birinin olumlu, diğerinin olumsuz olması durumunda, makale değerlendirilmek üzere üçüncü hakeme yönlendirilir. Hakem raporlarının olumlu olması durumunda yazı, yayım programına alınır.

3. Hakem raporlarına göre üzerinde değişiklik yapılması gereken yazılardaki tüm değişiklikleri yazarlar kendileri yaparlar. Son şekli verilen yazılar üzerinde yazarlarca bir değişiklik yapılmaz.

4. Hakem raporları gizlilik içerir. Yazarlar, hakem ve Yayın Kurulu'nun eleştiri, öneri ve düzeltmelerini dikkate almak zorundadırlar. Yazarlarla hakemler arasındaki iletişimi yalnızca Yayın Kurulu sağlar.

5. Yayım sırasında, ilk olarak yazının Yaratıcı Drama Dergisi'ne gönderiliş tarihi, sonra da hakemlerden alınan puanlar dikkate alınmaktadır.

6. Yaratıcı Drama Dergisi'nde yayımlanan yazıların sorumluluğu yazar/lar/a aittir. Yayımlanan yazılar konusunda Çağdaş Drama Derneği ve Yaratıcı Drama Dergisi sorumluluk kabul etmez.

7. Yayın Kurulu, gönderilen yazıları yayımlayıp yayımlamamakta serbesttir. Gönderilen yazılar yayımlansın veya yayımlanmasın yazara iade edilmez.

8. Yayımlanmış yazıların yayın hakları Yaratıcı Drama Dergisi’ne aittir.

9. Yaratıcı Drama Dergisi’nin ve yazar/ların adları kaynak gösterilerek alıntı yapılabilir.

10. Yazılar, yazar soyadına göre alfabetik sırada yayımlanır. İki ya da daha fazla yazarlı makalelerde yazılar, ilk yazarın soyadı esas alınarak sıralanıp yayımlanır.

11. Bir sayıda, aynı yazarın tek isim olduğu tek makale yayımlanabilir.

12. Dergiye gönderilecek yazılar;

a) Kağıt boyutları: A4 boyutunda kağıda, üst, alt, sağ ve soldan $2,5 \mathrm{~cm}$ boşluk bırakılarak (16x24,7 cm'lik alana), 1,5 satır aralıklı, 11 punto ve Times New Roman yazı karakteri kullanılarak yazılmalıdır.

b) Tablo, resim, şekil, grafik vb.: Derginin sayfa boyutlarının dışına taşmaması amacıyla 10x17 cm'lik alanı aşmamalıdır. Tablo, resim, şekil, grafik ve benzerlerinde daha küçük punto ve bir satır aralığı kullanılabilir. Tablo, şekil ve ekler, metin içerisinde, başlıklarıyla yer almalıdır. Tablo ve şekillerin öncesine ve sonrasına $12 \mathrm{nk}$ boşluk verilir, tablo başlıkları ve metin 10 punto, tablo ve numarası koyu yazılmalıdır.

c) Makale Başlığı; 14 punto, bağlaçlar hariç her sözcügün baş harfi büyük olarak yazılmalıdır. Başlık 17 sözcüŭü geçmemelidir. Proje kapsamında hazırlanan, sözlü bildiri, doktora ya da yüksek lisans tezinden üretilmiş veya destek almış çalışmalar başlığa * şeklinde dipnot ile verilir. Başlıktan sonra bir boşluk ile dipnot verilmelidir. 
d) Yazar Ad/lar/ı; 12 punto, ortalı, yazar adı soyadı sadece baş harfleri büyük olarak dipnotta rakamla $1-2$ şeklinde verilmelidir.

e) Özet Başı̆̆ğ; 10 punto ve koyu yazılmalıdır.

f) Türkçe/İngilizce Özet Metni; 10 punto, iki tarafa yaslı şekilde, 150-250 sözcük arası yazılmalıdır. Paragraf var ise paragraflar arası $6 \mathrm{nk}$ boşluk verilmelidir.

g) Anahtar Sözcükler Başıı̆̆ı; 10 punto, koyu yazılmalıdır.

h) Anahtar Sözcükkler; 10 punto büyüklüğünde, en fazla 5 anahtar sözcük yazılmalıdır.

i) Ana Başlıklar; (Giriş, Yöntem, Tartışma ve benzeri temel başlıklar)10 punto, koyu ve ortalı, altından ve üstünden $6 \mathrm{nk}$ boşluk ile yazılmalıdır.

j) Alt Başlıklar; paragraf başı 1,25 $\mathrm{cm}$ içerden, 11 punto, koyu, italik, iki yana yaslı yazilmalidir.

k) Paragraflar; paragraf başları 1,25 cm içeriden, 11 punto, iki yana yaslı, paragraflar arası $6 \mathrm{nk}$ boşluk bırakılarak yazılmalıdır.

13. Gönderilen yazılar; özetler ve kaynakça dahil 20 sayfayı geçmemelidir.

14. Gönderilen yazılar aşağıdaki bölümleri içermelidir:

a) Başık sayfası: Yazar/lar/ın tüm ve açık adları, çalıştıkları kurumlar, makale üst başlığının Türkçe ve İngilizce isimleri ile Türkçe ve İngilizce özetleri içermelidir.

b) Ana Metin: Ampirik çalışmalar; giriş, yöntem, bulgular, tartışma ve sonuç bölümlerini içermelidir.

c) Yöntem: Bu kısım; örneklem, veri toplama aracı ve işlem, verilerin analizi alt k1sımlarını içermek zorundadır. Derleme türü çalışmalar problemi ortaya koymalı, ilgili alanyazını etkili bir biçimde analiz etmeli, alanyazındaki eksiklikler, boşluklar ve çelişkilerin üzerinde durmalı ve çözümler için öneriler içermelidir. Diğer çalışmaların başlıklandırılmasında farklılıklar olabilir, ancak yazıların okuyucuyu sıkmayacak akıcılık ve bilimsellikte olması gerekmektedir.

d) Kaynakça: Hem metin içinde hem de kaynakçada Amerikan Psikologlar Birliği (APA) tarafindan yayınlanan Puplication Manual of American Psychological Association (5. Bask1 2001) adlı kitapta belirtilen yazım kurallarına uyulmalıdır.

15. Yayın Kurulu ile ilgili yazışmalar için e-posta adresi mutlaka yazılmalıdır.

16. Türkçe makalelerde metin içinde referans verirken mümkün olduğu kadar ana kaynağa ulaşılmalıdır.

17. Yazılar, Yaratıcı Drama Dergisi’nin e-posta adresine (cdddergi@gmail.com) gönderilmelidir.

18. Yayımlanan yazıların içeriğinde olabilecek çarpıtmalardan, alıntı yapan yazar ya da yazarlar sorumludur.

19. Yaratıcı Drama Eğitmenlik/Liderlik kurslarında bitirme projesi olarak yapılan çalışmalar danışman adı ikinci isim olmak üzere, danışman adıyla birlikte yayımlanır.

20. Başka bir yerde yayımlanan yazılar (yayımlanmış seminer ve kongre bildirileri, vb.), Yayın Kurulu'nun onayıla Yaratıcı Drama Dergisi'nde yayımlanabilir. 


\section{Yaratıcı Drama Dergisi Kaynakça Yazım Örnekleri}

Dergimizde Amerikan Psikologlar Derneği (Publication of Manual of American Psychological Association-APA) tarafindan yayınlanan yazım ilkeleri benimsenmiştir.

\section{Kitap}

Adıgüzel, Ö. (2013). Eğitimde yaratıcı drama (4.bs.). Ankara: PegemA Yayınları.

Gönderme: (Adıgüzel, 2013, s.234)

\section{İki Yazarlı Kitap}

Kitson, N. ve Spiby, I. (1997). Drama 7-11: Developing primary teaching skills (3rd ed.). New York:

Routledge Publication.

\section{Kitap İçinde Bölüm}

Güven, İ. (2008). Okul öncesi drama etkinliklerinde ilkeler. A. Öztürk (Yay. Haz.). Çocukta Yaratıcılık ve Drama içinde (ss. 199-212). Eskişehir: Anadolu Üniversitesi Yayınları.

Gönderme: (Güven, 2008, s.207)

\section{Çeviri Kitap}

Lewis, B. (2000). Modern Türkiye'nin doğuşu (M. Kıratlı, Çev.). Ankara: Türk Tarih Kurumu. Gönderme: (Lewis, 2000, s. 12)

\section{Editörlü Kitap}

Kilpatrick, J. (2004). (Ed.). A Research companion to principles and xtandards for school mathematics,

Reston, VA: NCTM, Inc. Educational Research Information Center (ERIC)

\section{Tek Yazarlı Makale}

San, İ. (1990). Eğitimde yaratıcı drama. Ankara Üniversitesi Eğitim Bilimleri Fakültesi Dergisi, 23(2), 573-582.

Gönderme: (San, 1990, s. 574)

\section{İki yazarlı makale}

Özdemir, P. ve Akkuş-Çıkla, O. (2005). Use of creative drama in science and mathematics by preservice elementary teachers. Hacettepe Üniversitesi Eğitim Fakültesi Dergisi, 27, 157-166.

\section{Elektronik Makale}

Karakelle, S. (2012). Üstbilişsel farkındalık, zeka, problem çözme algısı ve düşünme ihtiyacı arasındaki bağlantılar. Eğitim ve Bilim, 37(164), 237-250. 3 Aralık 2014 tarihinde http:// egitimvebilim.ted.org.tr/index.php/EB/article/view/779/376 adresinden erişildi.

Gönderme: (Karakelle, 2012, s. 240) 


\section{Tez}

Aykaç, M. (2011). Türkçe ögretiminde çocuk edebiyatı metinleriyle kurgulanan yaratıcı drama etkinliklerinin anlatma becerilerine etkisi. Yayınlanmamış doktora tezi, Ankara Üniversitesi Eğitim Bilimleri Enstitüsü Hacettepe, Ankara.

Gönderme: (Aykaç, 2011, s.67)

\section{Bildiri}

Akfirat Önalan, F. ve Tunç, A. (2003). Grup rehberlik etkinliklerinde yaratıcı dramanın yeri: Yaparak yaşayarak öğrenme. VII. Ulusal Psikolojik Danışma ve Rehberlik Kongresi 09-11 Temmuz 2003 içinde (s. 91-93). İnönü Üniversitesi, Malatya: PegemA Yayınc1lık, 139-140.

Gönderme: (Akfirat Önalan ve Tunç, 2003, s. 92)

\section{Web Sayfaları}

UNESCO. (2013). World Heritage list. UNESCO web sitesinden 21 Aralık 2013 tarihinde erişildi: http://whc.unesco.org/en/list

Gönderme: (UNESCO, 2013)

\section{Şekiller}

Her şeklin numarayı içeren bir başlığı olmalı ve bu başlık şeklin altına yazılmalıdır.

\section{Tablolar}

Tablo numarası ve adı tablonun üstünde yer almalıdır. Tablo adı, tablo numarasının altından başlayarak, sola dayalı bir şekilde, baş harfleri büyük ve italik olarak yazılmalıdır. Tablo sadece yatay çizgiler kullanılarak oluşturulmalıdır. Aşağıda bir tablo örneği verilmiştir.

Tablo 1. Yaratıcı Drama Temelli Hazırlanan Fen ve Matematik Ders Planlarının Sinıf Düzeyine ve Ünitelere Göre Dă̆ılımı

\begin{tabular}{cccccc}
\hline & 1. sınıf & 2. sınıf & 3. sınıf & 4. sinıf & 5. sınıf \\
\hline \multirow{2}{*}{ Yaşayan canlılar } & Fen ders planları & & & & \\
Elektrik & - & - & - & 5 & 1 \\
& - & - & 1 & 3 & - \\
Sayılar & Matematik ders planları & & & & \\
Geometri & - & - & 1 & - & 1 \\
Ölçme & 1 & - & 3 & 1 & 1 \\
Veri analizi & - & 2 & 1 & - & - \\
\hline
\end{tabular}




\section{Submission Guidelines for Creative Drama Journal}

\section{Articles sent to Creative Drama Journal for Publication:}

1. First, it is scanned with plagiarism programs such as iThenticate or Turnitin, and studies with a quotation rate of less than $15 \%$ are first reviewed by the editor and submitted to the editorial board. The articles, which are decided to be published, are examined by at least two referees to be evaluated from a scientific point.

2. In the event that one of the referee reports is positive and the other one is negative, article is directed to the third referee to be evaluated. In case of positive referee reports, article is included in the publication program.

3. Authors make all changes in the articles on which changes are required according to referee reports on their own. No change is made on the final versions of the articles by the authors.

4. Referee reports include privacy. Authors have to take the critics, suggestions and corrections of the referee and Editorial Board into consideration. Communication between authors and referees is only ensured by the Editorial Board.

5. During publication, firstly the sending date of the article to Creative Drama Journal is considered and then the scores obtained from the referees are considered.

6. Responsibility of the articles published in Creative Drama Journal pertains to the author/s/ of the articles. Contemporary Drama Association and Creative Drama Journal do not accept responsibility related to the published articles.

7. The Editorial Board is free to publish and not to publish the submitted articles. Submitted articles are not returned to the author whether they are published or not.

8. The rights of publication of the published articles pertain to Creative Drama Journal.

9. Quotation can be made by giving reference of Creative Drama Journal and the name/s of the author/s.

10. Articles are published in alphabetical order by authors' surnames. In articles with two or more authors, articles are sorted and published based on the first author's surname.

11. In an issue, one article can be published in which the same author is the only name.

12. Articles to be sent to the journal;

l) Paper sizes: It should be written on A4 sized paper with 1.5 line spacing and without end of line hyphenation by leaving $2,5 \mathrm{~cm}$ space from top, bottom and left (on an area of 16x24,7 cm) and by using 11 point size and Times New Roman typeface.

m) Tables, pictures, figures, graphics, etc..: They should not exceed the area of 10x17 $\mathrm{cm}$ in order not to extend beyond the journal page sizes. Smaller font size and one line space can be used on tables, pictures, figures, graphics and so on. Tables, figures and appendices should be included in the text with their titles. $12 \mathrm{pt}$ space is left before and after tables and figures, table titles and text should be 10 point size, table and its number should be written in bold.

n) Title of the Article; It should be written as 14 point size, and the first letter of every word should be written as capital letter except for the conjunctions. Title should not 
exceed 17 words. Studies, which are produced from verbal notification and doctoral or postgraduate thesis or which received support, are indicated by footnote in the title as *. Footnote should be given by a space after title.

o) Name/s of the Author/s; They should be given in footnote in figures as 1-2 along with the title, institution he/she works and e-mail address as 12 point size, centered, and only the first letters of author name and surname should be capital letter.

p) Title of Abstract; It should be written as 10 point size and in bold.

q) Turkish / English Text Abstract; It should be written as 10 point size, italic, justified alignment and between 90-120 words. If there is a paragraph, $6 \mathrm{pt}$ space should be given between paragraphs.

r) Title of the Keywords; It should be written as 10 point size and in bold.

s) Keywords; Maximum 5 keywords should be written as 10 point size.

t) Main Titles; (Introduction, Method, Discussion and similar basic titles) It should be written as 11 point size, bold and centered, in the way that only the first letters are capital letter, and with $6 \mathrm{pt}$ space from top and bottom.

u) Subtitles; paragraph indentation should be written as $1.25 \mathrm{~cm}$ inside, 11 point size, bold, italic and justified alignment.

v) Paragraphs; Paragraph indentations should be written as $1.25 \mathrm{~cm}$ inside, 11 point size, justified alignment by leaving $6 \mathrm{pt}$ space between paragraphs.

13. Submitted articles should not exceed 20 pages, including abstracts and references.

14. Submitted articles should include the following sections:

e) Title page: It should include the full name/s and explicit name/s of the author/s, the institutions they work, Turkish and English names of top article title and its Turkish and English abstracts.

f) Main Text: Empirical studies should include the sections of introduction, method, findings, discussion and the results.

g) Method: This section must include the sub-sections of sampling, data collection and processing and analysis of data. Review article-type studies should reveal the problem, should analyze the relevant literature effectively, should put emphasis on shortcomings, gaps and contradictions in the literature and should include suggestions for solutions. There may be differences in giving title of other studies, however, articles should be fluent and scientific that will not make the readers bored.

h) References: Spelling rules specified in the book called Publication Manual of American Psychological Association (5th edition 2001) published by American Psychological Association (APA) should be obeyed both in the text and references.

15. E-mail address must be written for correspondences related to the Editorial Board.

16. While giving reference in the texts in Turkish articles, main source should be attained as far as possible.

17. Articles should be sent to Creative Drama Journal's e-mail address (cdddergi@gmail.com). 
18. Author or authors who cite/s are responsible for the distortions that may be in the content of the published articles.

19. Studies carried out as dissertation in Creative Drama Instructor/Leadership courses are published with the name of advisor including the advisor name and second name.

20. The articles published in somewhere else (published seminar and conference proceedings, etc.) can be published in Creative Drama Journal with the approval of the Editorial Board.

\section{Citation Format and Style Guide for Creative Drama Journal}

Publication of Manual of American Psychological Association-APA is adopted by our journal for formatting and style.

\section{JOURNALS}

\section{One Author}

San, İ. (1998). The development of drama in education in Turkey, Research in Drama Education, 3, 1, 96.

\section{Two Authors}

Özdemir, P. ve Akkuş-Çıkla, O. (2005). Use of creative drama in science and mathematics by preservice elementary teachers. Hacettepe Üniversitesi Ĕ̆itim Fakültesi Dergisi, 27, 157-166.

\section{BOOKS AND CHAPTER IN BOOKS}

\section{One Author}

Üstündağ, T. (2004) Yaratıcı drama öğretmenimin günlüğü (6. bask1). Ankara: PegemA Yayınc1lık.

\section{Two Authors}

Kitson, N. ve Spiby, I. (1997). Drama 7-11: Developing primary teaching skills (3rd ed.). New York: Routledge Publication.

\section{Editor instead of author}

Hemingway, E. (1999). The killers. In J. Updike \& K. Kenison (Eds.), The best American short stories of the century (pp.78-80). Boston, MA: Houghton Mifflin.

Kilpatrick, J. (2004). (Ed.). A Research companion to principles and standards for school mathematics, Reston, VA: NCTM, Inc. Educational Research Information Center (ERIC)

\section{Thesis or dissertation}

Duatepe, A. (2004). The effects of drama based instruction on seventh grade students' geometry achievement, Van Hiele geometric thinking levels, attitude toward mathematics and geometry. Unpublished $\mathrm{PhD}$ dissertation, Ankara: METU. 


\section{Published Presentation Papers}

Adıgüzel, H. Ö. (2002). Eğitim bilimlerinde ve sanat eğitiminde yöntem, disiplin ve sanatsal boyutlarıyla yaratıcı drama. 11. Eğitim Bilimleri Kongresi, Yakın Doğu Üniversitesi, KKTC, 23-26 Ekim.

\section{Online Sources}

\section{Online Journal}

Andersen, C. (2004, June). Learning in "As-If" worlds: Cognition in drama in education. . 43, 4, Retrieved November 3, 2004, Academic Index.

\section{Citing in the text}

\section{One Author}

Linn's (1999) study...

As it is indicated (Way, 1973) in a new research,...

\section{Two or more authors}

If the paper is published by two authors, then full names of both authors must be written through all the text. If the paper is published by three or more authors, then in the first citation full names of authors must be written, but then for other citations, only the first authors' first name must be written and other authors must be written as "others".

\section{Figures}

All the figures must have a title that include also a number. And this title must be under the figure.

\section{Tables}

The name and the number of table must be at the top of the table. Name of the table must begin after the number of table. And it must be aligned-left, written by initial capital letters and italic. The table must be constituted by only horizontal lines. You can find an example below.

Tablo 1. Yaratıcı Drama Temelli Hazırlanan Fen ve Matematik Ders Planlarının Sınıf Düzeyine ve Ünitelere Göre Dağılımı

\begin{tabular}{cccccc}
\hline & 1. sınıf & 2. sinıf & 3. sınıf & 4. sinıf & 5. sinıf \\
\hline \multirow{2}{*}{ Yaşayan canlılar } & Fen ders planları & & & & \\
Elektrik & - & - & - & 5 & 1 \\
& - & - & 1 & 3 & - \\
Sayılar & Matematik ders planları & & & & \\
Geometri & - & - & 1 & - & 1 \\
Ölçme & 1 & - & 3 & 1 & 1 \\
Veri analizi & - & 2 & 1 & - & - \\
\hline
\end{tabular}


